\title{
THE TUNES OF DIPLOMATIC NOTES
}

Music and Diplomacy in Southeast Europe

$$
\left(18^{\text {th }}-20^{\text {th }}\right. \text { century) }
$$

Edited by Ivana Vesić, Vesna Peno, Boštjan Udovič 
THE TUNES OF DIPLOMATIC NOTES

Music and Diplomacy in Southeast Europe

$\left(18^{\text {th }}-20^{\text {th }}\right.$ century) 
${ }^{*}$ This edited collection is a result of the scientific project Identities of Serbian Music Within the Local and Global Framework: Traditions, Changes, Challenges (No. 177004, 2011-2019), funded by the Ministry of Education, Science and Technological Development of the Republic of Serbia, and implemented by the Institute of Musicology SASA (Belgrade, Serbia). It is also a result of work on the bilateral project carried out by the Center for International Relations (Faculty of Social Sciences, University of Ljubljana) and the Institute of Musicology SASA (Belgrade, Serbia) entitled Music as a Means of Cultural Diplomacy of Small Transition Countries: The Cases of Slovenia and Serbia (with financial support of ARRS). The process of its publishing was financially supported by the Ministry of Education, Science and Technological Development of the Republic of Serbia. 


\title{
THE TUNES OF DIPLOMATIC NOTES MUSIC AND DIPLOMACY IN SOUTHEAST EUROPE $\left(18^{\text {th }}-20^{\text {th }}\right.$ CENTURY)
}

\author{
Edited by \\ Ivana Vesić, Vesna Peno, Boštjan Udovič
}





\section{CONTENTS}



1. Introduction. .......................................... 9

Ivana Vesić, Vesna Peno, Boštjan Udovič

\section{Part I. Diplomacy Behind the Scenes: Musicians' Contact With the Diplomatic Sphere}

2. The European Character of Dubrovnik and the Dalmatian Littoral at the End of the Enlightenment Period: Music and Diplomatic Ties of Luka and Miho Sorkočević, Julije Bajamonti and Ruđer Bošković.......................... 17 Ivana Tomić Ferić

3. The Birth of the Serbian National Music Project Under the Influence of Diplomacy.....37 Vesna Peno, Goran Vasin

4. Petar Bingulac, Musicologist and Music Critic in the Diplomatic Service....... 53 Ratomir Milikić

\section{Part II. Reflections of Foreign Policies in National Music Spheres}

5. Musical Life in Belgrade as an Instrument of Global Political Polarization on the Eve of WWII ......................................... 65

Ranka Gašić

6. Allies in Music: French Influences and Role Models in the Cvijeta Zuzorić Association of Friends of Arts.................................. 77

Srdan Atanasovski

7. The Echoes of Diplomatic Disputes. The Macedonian Question in the Work of Serbian and Yugoslav Music Scholars

Ivana Vesić

8. Before and After the "Treaty of Eternal Friendship." Musical and Cultural Contacts Between Bulgaria and Yugoslavia In the 1930s (an Attempt at Typology) ....... 121 Stefanka Georgieva

9. Music During the Cold War: A Romanian Story Florinela Popa

10. "Ideologically Progressive Art" Meets Western Avant-Garde. 155 Lenka Křpková 


\section{Part III. Music as a Means of Cultural Diplomacy}

11. Music and Cultural Diplomacy: Presentation of the "New Yugoslavia" in France After 1945 ............................................... 167 Aleksandra Kolaković

12. Sounding the Turn to the West: Music and Diplomacy of Yugoslavia After the Split With the USSR and the Countries of the "People's Democracy" (1949-1952) . .. 185 Biljana Milanović

13. "Folklore Diplomacy" - the Role of Musical Folklore in Yugoslavia's Foreign Policy

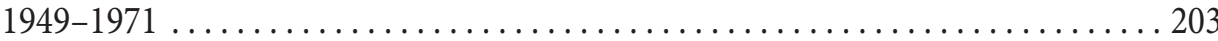
Ivan Hofman

14. Yugoslav Music Diplomacy in the 1960s and 1970s—-the Cases of Esma Redžepova and the Band Magnifico.

Julijana Papazova

15. Cultural Cooperation Between the Non-Aligned Yugoslavia and the Neutral Finland From the 1960s to the 1980s ................................. 241 Maja Vasiljević

Notes on Contributors. 257 


\section{Acknowledgements}

This edited collection was inspired by a 2-day international conference held in Belgrade in May 2019, and was carefully prepared by a group of scholars from the Institute of Musicology SASA and other academic institutions from Central and Southeast Europe. The lengthy discussions and fruitful exchange of ideas that took place at the conference created fertile ground for the preparation of the chapters that make up this collection. Of great value to that end were the dialogues between the authors, reviewers and editors. We owe thanks to numerous colleagues that contributed to the preparation of the conference and this volume. Particularly important among them were the members of the conference's scholarly committee, professors Leon Stefanija (University of Ljubljana, Faculty of Arts), Tatjana Marković (University of Music and Performing Arts Vienna) and the late professor Vesna Mikić (University of Arts in Belgrade, Faculty of Music). Equally important were the comments and insights of the reviewers of this collection as well as the language editor Aleš Lampe. We are also very thankful to the authors of the chapters, who patiently revised their work several times and responded promptly to the editors' requests in the extremely unfavorable conditions of a global pandemic. Finally, we express our gratitude to Jelena Mandić of the Ministry of Education, Science and Technological Development of the Republic of Serbia, who helped us resolve certain administrative issues and thus obtain the necessary institutional support, as well as to the management and administrative staff of the Faculty of Social Sciences of the University of Ljubljana and the Institute of Musicology SASA, who had a crucial role in the publishing of this volume.

Belgrade and Ljubljana, December 2020 



\section{Introduction}

\section{Ivana Vesić, Vesna Peno, Boštjan Udovič}

Culture and cultural artefacts have been an important instrument of establishing and maintaining political relations between different peoples and states since the emergence of diplomatic practice in the $17^{\text {th }}$ century, and some authors date this practice as far back as the period of ancient civilizations. ${ }^{1}$ Despite the long history of using culture for different political purposes and interests, particularly in relation to bonding peoples and states or increasing their influence, it was not until the creation of nation-states and, above all, the development of modern mass media such as widespread newspapers and journals, and regional and national radio and TV stations that this practice flourished and gained prominence. Therefore, it is no coincidence that researchers of this topic mainly on the last two centuries, particularly the Cold War era as one of the peak moments when it comes to creatively employing cultural products to achieve an array of nationally and internationally oriented political goals. ${ }^{2}$ Apart from revealing how diverse cultural actions contributed to the promotion of the countries of both the Western and the Eastern Bloc, along with their dominant values and ideology, a large number of studies published in the recent decades have also served to indirectly point to the necessity of thorough examination of the cultural part of foreign policy making and international relations, to providing it a stronger theoretical foundation and to the importance of including in the analyses different cases from different periods. Academics active in this area emphasize the need for greater clarity in defining key concepts and classificatory schemes in the analysis of cultural segments of international relations. For instance, Ang, Isar Ray and Mar highlight the popularity and, at the same time, the obscurity of the concept of cultural diplomacy, which has been given a dominant place in debates starting from the beginning of the $21^{\text {st }}$ century. ${ }^{3}$ As these authors observe, the semantic field of this term has

1 See Richard T. Arndt, The First Resort of Kings: American Cultural Diplomacy in the Twentieth Century (Potomac Books, 2006), 1-23.

2 Hundreds of thousands of studies dedicated to this topic that are mainly focused on the post-WWII period can be found in the most prestigious scholarly databases and search engines, including Google Scholar, EBSCO Discovery Service, JSTOR, Springer Link, etc.

3 Ien Ang, Yudhisthir Isar Ray, Phillip Mar, "Cultural Diplomacy: Beyond the National Interest?" International Journal of Cultural Policy 21/4 (2015): 365-381. 
"broadened considerably over the years," making it applicable to "pretty much any practice that is related to purposeful cultural cooperation between nations or group of nations." 4 This tendency not only contributed to a blurring of the lines between the concept of cultural diplomacy and other concepts that evolved prior to its expansion, including international cultural relations, public diplomacy and soft power, but also undermined the efforts to create a more coherent approach to the research of cultural phenomena in the domain of international relations. The issue is exacerbated by the heterogeneous disciplinary framing of this topic. Although it is mainly explored in the areas of political sciences and history, interest in researching the phenomenon also appears in other fields, including sociology, art history, musicology, ethnomusicology, etc. Apart from the fact that uncritical use of the concept of cultural diplomacy has made it "a floating signifier," 5 an even more challenging consequence, in our opinion, is the inability to properly link the research results to already produced knowledge on the one hand and on the other to systematically compare cases from different historical and geopolitical settings.

Notwithstanding certain difficulties that manifest in exploring the cultural part of international relations in the recent decades, the abundant and steadily growing collection of studies created after the fall of the Berlin Wall indicates that researchers are recognizing the importance and relevance of this topic along with its multifaceted potential. It is the potential that this research area offers for a broader and more nuanced understanding of the sphere of international affairs, along with capturing the complexities of the process of constructing a national culture and national cultural policy-making, that served as the primary motive for the preparation of this collection. Another very important aspect was that cultural phenomena have been on the margin in the research of the foreign policies of countries of Southeast Europe-including the countries that belonged to the Eastern Bloc-and have not been given much attention in discussions. Moreover, the presence of music in the conducting of international relations of the peoples and states of this part of Europe in modern history is almost completely neglected in existing publications.

Encouraged by the growing interest in the examination of the role of music in the sphere of international affairs from the $17^{\text {th }}$ century on, ${ }^{6}$ which has become evident in the last decade, and intrigued by the possibilities it brings for gaining new insights into cultural and musical phenomena both in the national and international context, we decided to gather scholars from different fields (history, musicology) from Southeast and Central Europe who are familiar with different historical periods. The intended focus was the era of nation-states, particularly

\footnotetext{
4 Ibid., 366.

5 Ibid., 367.

6 See the list of selected studies in the bibliography section.
} 
from the $18^{\text {th }}$ to $20^{\text {th }}$ century, but above all after World War I. In geographical terms, we focused on the peoples and countries of Southeast Europe, particularly those that were part of former Yugoslavia, together with parts of Central Europe that belonged to the Eastern Bloc (Czechoslovakia). The main aim was not to give final and axiomatic answers to issues concerning the employment of music and musical activities in international relations in the given period and geopolitical settings, but to point to the diversity of interconnections between the spheres of music, culture, international relations and politics as well as their outcomes. Our starting point was the assumption that culture serves as one of the sources for international relations, and that its relevance is determined by the historical circumstances and dominant tendencies in the national and international settings (development of states' cultural sphere, their economic and political power, power relations on the international scene, etc.). Apart from that, it is also important to create a clear conceptual distinction between the more general contexts of the use of culture and music in the sphere of international affairs, where not only the state and its bodies but also non-state actors have a crucial contribution (international cultural relations) through formal and informal occasions, and the more specific contexts where the primary role is statecraft (cultural diplomacy).

As a result, fourteen studies were prepared and divided into three sections. The first part, entitled "Diplomacy Behind the Scenes: Musicians' Contact With the Diplomatic Sphere" comprises of three chapters focusing on different phenomena-the intensive political and intellectual networking of a circle of $18^{\text {th }}$-century Croatian diplomats, composers and polymaths (Luka and Miho Sorkočević, Julije Bajamonti and Ruđer Bošković) with their European fellows and the resulting intercultural exchanges (Ivana Tomić Ferić); the influence of the political and diplomatic engagement of the Serbian Metropolitan in the Habsburg Monarchy, Josif Rajačić, in creating the project of Serbian national music (Vesna Peno and Goran Vasin); the particularities of the diplomatic career of one of the most notable $20^{\text {th }}$-century Serbian and Yugoslav music scholars, Petar Bingulac (Ratomir Milikić). Besides revealing previously less known or completely unknown facts, these studies indicate the relevance of considering different types of international contacts of individuals and groups in the process of establishing national (and regional) policies, as well as highlight the role of cultural and social capital in the activities of state diplomats.

The second part, entitled "Reflections of Foreign Policies in National Music Spheres," contains six chapters dedicated to discussing how the established foreign policies of selected states, including interwar Yugoslavia and Bulgaria, and postWWII Romania and Czechoslovakia, affected music production, distribution, consumption and research. Among other issues, attention was given to the power struggles between Great Britain and the Third Reich in the 1930s and the way they 
manifested in the musical life of Belgrade, at the time the capital of the Kingdom of Yugoslavia (Ranka Gašić); the influence of Yugoslavia's political alliance with France between the two world wars on the cultural and music production of some of the most prestigious artistic circles in Belgrade (Srđan Atanasovski); the YugoslavBulgarian diplomatic disputes after the Great War over the territory and peoples of Vardar Macedonia and their impact on the research of the folk music of that region (Ivana Vesić), as well as the outcomes of rapprochement between the two countries after 1937 in the domain of cultural exchange (Stefanka Georgieva). Moreover, this section presents the different stages of foreign policy of Communist Romania from 1948 to 1989 and how they marked music production and distribution in this country along with the reception of foreign musical works (Florinela Popa); the effects of the political turn in Czechoslovakia in 1948 and its adherence to the policies of the Eastern Bloc on the transforming the dominant views on music aesthetics, poetics and national music production (Lenka Křupková). These chapters convincingly point to the significance of power relations in the international arena in the shaping of (national) cultural and music spheres, as well as the existence of a correlation between activities in the national and international settings, and the resulting necessity of simultaneously observing two different levels-national and international-due to their close intertwining.

The third part, entitled "Music as a Means of Cultural Diplomacy," consists of five chapters offering a detailed insight into the strategies and programming of cultural cooperation and exchange of socialist Yugoslavia in different phases of its existence. Among other issues, the chapters explore how cultural and musical activities abroad followed the efforts of Yugoslav authorities to establish closer ties with certain countries, to promote Yugoslavia's achievements, values and ideology, and to counter negative representations. Apart from the in-depth scrutiny of Yugoslav foreign policy towards France (Aleksandra Kolaković) and Finland (Maja Vasiljević), where the general tendencies and turns were brought to light through the extent and prestige of the cultural and musical undertakings prepared, another very comprehensive and illuminative study is the examination of how international tours of professional folk dance ensembles were employed for the purpose of realizing the country's various political goals in the international framework (Ivan Hofman), as well as the study on the tours of popular bands and folk music performers (Julijana Papazova). The Yugoslav political shift in the late 1940s and its ramifications particularly in connection to exporting its musical products and accomplishments to the Western Bloc were also thoroughly examined (Biljana Milanović). 


\section{Bibliography:}

Ang, Ien, Isar Ray, Yudhisthir, Mar, Phillip. "Cultural Diplomacy: Beyond the National Interest?" International Journal of Cultural Policy 21/4 (2015): 365-381.

Ansari, Emily Abrams. The Sound of a Superpower: Musical Americanism and the Cold War. Oxford University Press, 2018.

Arndt, Richard T. The First Resort of Kings: American Cultural Diplomacy in the Twentieth Century. Potomac Books, 2006.

Berghahn, Volker R. America and the Intellectual Cold Wars in Europe. Princeton: Princeton University Press, 2001.

Campbell, Jessica L. "Shaping Solidarity: Music, Diplomacy, and Inter-American Relations, 1936-1946." PhD diss., University of Connecticut, 2010.

Channick, Joan. “The Artist as Cultural Diplomat." American Theatre Magazine 22/5 (2005): 4.

Coombs, Philip. The Fourth Dimension of Foreign Policy: Education and Cultural Affairs. New York: Harper and Row Publishers, 1964.

Cummings, Milton C. Cultural Diplomacy and the United States Government: A Survey. ICD Institute for Cultural Diplomacy, Centre for Arts and Culture, 2003.

Dimić, Ljubodrag. Agitprop kultura. Agitpropovska faza kulturne politike u Srbiji 1945-1952. Belgrade: Rad, 1988.

Doknić, Branka. Kulturna politika Jugoslavije 1946-1963. Belgrade: Službeni glasnik, 2013. [Orig. in Serbian Cyrillic]

Dragićević Šešić, Milena (Ed.). Cultural Diplomacy: Arts, Festivals and Geopolitics. Belgrade: Creative Europe Desk Serbia, Faculty of Dramatic Arts in Belgrade, 2017.
Eschen, Penny von. Satchmo Blows Up the World: Jazz Ambassadors Play the Cold War. London: Harvard University Press, 2004.

Fossler-Lussier, Danielle. Music in America's Cold War Diplomacy. University of California Press, 2015.

Gienow-Hecht, Jessica C. E. (Ed.). Decentering America: Explorations in Culture and International History. New York: Berghahn Books, 2007.

Gienow-Hecht, Jessica C. E. Sound Diplomacy: Music and Emotions in Transatlantic Relations, 1850-1920. Chicago: The University of Chicago Press, 2009.

Gienow-Hecht, Jessica C. E., Donfried, Mark C. (Eds.). Searching for a Cultural Diplomacy. New York-Oxford: Berghahn Books, 2010.

Irving, David R. M. "Lully in Siam: Music and Diplomacy in French-Siamese Cultural Exchanges, 1680-1690.” Early Music 3 (2012): 393-420.

Mikkonen, Simo, Suutari, Pekka (Eds.). Music, Art and Diplomacy: East-West Cultural Interactions and the Cold War. London: Routledge, 2017.

Mitchell, John M. International Cultural Relations. London: Allen \& Unwin, 1986.

Nisbett, Melissa. "New Perspectives on Instrumentalisation: An Empirical Study of Cultural Diplomacy." International Journal of Cultural Policy 19/5 (2013): 557-575.

Nisbett, Melissa, Doeser, James. The Art of Soft Power: A Study of Cultural Diplomacy at the UN Office in Geneva. London: King's College London, 2017.

Nye, Joseph S. Jr. Bound to Lead: The Changing Nature of American Power. New York: Basic Books, 1990. 
Nye, Joseph S. Jr. Soft Power: The Means to Success in World Politics. New York: Public Affairs, 2004.

Parmar, Inderjeet, Cox, Michael (Eds.). Soft Power and US Foreign Policy: Theoretical, Historical and Contemporary Perspective. London-New York: Routledge, 2010.

Perišić, Miroslav. Diplomatija i kultura - Jugoslavija, prelomna 1950. Belgrade: Narodna biblioteka Srbije, Institut za noviju istoriju Srbije, 2013.

Prévost-Thomas, Cécile, Ramel, Frédéric (Eds.). International Relations, Music and Diplomacy. Sound and Voices on the International Stage. London: Palgrave Macmillan, 2018.
Reeves, Julie. Culture and International Relations: Narratives, Natives and Tourists. London: Routledge, 2007.

Saunders, Frances S. The Cultural Cold War: The CIA and the World of Arts and Letters. New York: The New Press, 1999.

Singh, J. P. (Ed.). International Cultural Policies and Power. Basingstoke: Palgrave Macmillan, 2010.

Toynbee, Jason, Vis, Farida. "World Music at the BBC World Service, 1942-2008: Public Diplomacy, Cosmopolitanism, Contradiction." Media, Culture \& Society 32/4 (2010): 547-564. 


\section{Part I.}

Diplomacy Behind the Scenes:

Musicians' Contact

With the Diplomatic Sphere 



\title{
The European character of Dubrovnik and the Dalmatian littoral at the end of the Enlightenment period: music and diplomatic ties of Luka and Miho Sorkočević, Julije Bajamonti and Ruđer Bošković*
}

\author{
Ivana Tomić Ferić
}

Taking a look into the life and artistic paths of prominent Croatian Enlightenment thinkers, musicians and diplomats in the context of their cities Dubrovnik (Luka and Miho Sorkočević, Ruđer Bošković) and Split (Julije Bajamonti), this paper intends to point to the broader context of their foreign activities and communication, whether direct or through extensive epistolary correspondence, with European intellectuals. For the purpose of presenting new thoughts and findings from recent musicological research, the text illuminates unknown data about Bajamonti's (musical) legacy, as well as about the relationship between composers from the Croatian coastal area in the late Settecento (the 1700s), clarifying their role in the penetration of European Enlightenment ideas to Croatian territory.

The reception of different foreign cultures, convergences, influences and permeations, and the reception and transformation of ideas testify to the intensive and continuous dialogue of cultural environments, circles and aspirations in this part of the Mediterranean. Generations of Croatian writers, philosophically and theologically educated scientists and artists were shaped in major European university centers, gaining academic titles, publishing their works and holding lectures at foreign universities and academies, engaging at the same time with central issues and ideals of their time and performing their tasks in the highest positions, both ecclesiastical and secular. All these characteristics are common to the abovementioned historical figures, who were part of cultivated Europe and were involved in the political and social changes that not only impinged on them but caught them in their whirlwind. Brothers Luka and Miho Sorkočević (and later Luka's son Antun, also a diplomat and musician) took part in these changes as high-ranking officials of the Dubrovnik Republic, while Julije Bajamonti, a learned polymath from Split, exerted a specific influence on the cultural and social life of

* This research has been fully supported by the Croatian Science Foundation under the project GIDAL IP-2016-06-2061. 
Croatian intellectuals, as well as on their presentation far outside Croatian lands, with his versatility and epistolary exchanges. ${ }^{1}$

Dubrovnik patrician, Count Luka Sorgo (Sorkočević in the Croatian version of the name; Dubrovnik, 1734-1789) was the ambassador of the Dubrovnik Republic to France in 1765, during the reign of Louis XV, and when Joseph II became the Emperor of Austria, the Republic sent him to the court in Vienna (in 1781). During his relatively brief stint in Vienna, he met several leading composers and poets of his time (Glück, Haydn, Metastasio), which was a valuable experience for his later life and work.

Like Sorgo, Ruđer Josip Bošković (Dubrovnik, 1711 - Milan, 1787), a famous naturalist and philosopher, also carried out very delicate diplomatic missions for the Dubrovnik Republic throughout his life. In the period between 1755 and 1776, he developed strong social contacts, and enjoyed a great reputation with the Holy See during his time in Paris (November 1759 - May 1760). He also had excellent relations with high-ranking French state authorities, especially with the Ministry of Foreign Affairs and the Versailles court, and was highly respected among French and English scholars (he became a fellow of the Royal Society in London in 1761). In the Austrian capital, he was recognized both for his diplomatic merits and as an outstanding scholar and author of the seminal work Philosophiae naturalis theoria redacta ad unicam legem viruim in natura existentium, published in Vienna in 1758. With his connections, he prepared Sorgo's trip to Vienna and arranged a welcoming atmosphere in his new diplomatic mission, as well as bringing him in contact with the famous Italian poet and most celebrated European librettist of the $18^{\text {th }}$ century, Pietro Metastasio (then residing in Vienna). ${ }^{2}$ Sorgo was a family

\footnotetext{
1 Most of Bajamonti's correspondence has been preserved in the Bajamonti Archive of the Archaeological Museum Split [Arheološki muzej u Splitu (AMS)]. It is a collection of letters and drafts in a number of volumes on a total of 227 A4-size pages, covering the period from April 16, 1787 to October 17, 1800 (a total of 1244 drafts), as well as fifty pages from August 9, 1771 to July 20, 1800. The alphabetical index of Bajamonti's drafts distinguishes 230 addressees-local and foreign scholars, writers, artists and public figures - with whom Bajamonti, occasionally or frequently, corresponded. Among others, we will mention the learned Hvar bishop Ivan Dominic Stratico, writers Ivan Luka Garanjin and Radoš Michieli-Vitturi from Trogir, French author Joseph de Lalande, Viennese librarian Michael Denis, astronomy professor at the Padua University Giuseppe (Josip) Toaldo, Leone (Lav) Urbani, a doctor from Split with a Venetian address, governor-generals of Dalmatia Paolo Emilio Canal and Angelo Diedo, Venetian printer and publisher Giacomo (Jakov) Storti, members of the Sorgo family, etc. See Ivana Tomić Ferić, "Susreti prekojadranskih kultura u razdoblju klasicizma: Bajamontijeve glazbene i izvanglazbene veze [Meetings of Trans-Adriatic Cultures in the Classical period: Bajamonti's Musical and Non-Musical Relations]," Bašćinski glasi 13 (2017/18): 73-121.

2 See Vjera Katalinić, "Korisne veze: Luka Sorkočević - Ruđer Bošković - Pietro Metastasio [Useful Liaisons: Luka Sorgo-Ruggiero Boscovich-Pietro Metastasio]," Arti musices 46/1 (2015): 27-35.
} 
friend of the Boškovićs, and he corresponded with Ruđer Bošković on various topics, particularly regarding the affairs of the Republic. ${ }^{3}$

As one of the most learned and most progressive figures, not only in Dalmatian but also in all of Croatian history, Julije (Giulio) Bajamonti (1744-1800), a native of Split (of Italian origin) - polymath, physician, writer, translator, linguist, bibliographer, historian, ethnographer, philosopher, economist, chemist, musician and musical theorist ${ }^{4}$ - developed strong and friendly relations with the Sorgo brothers. He probably met Luka Sorgo through his younger brother Miho (Dubrovnik, 1739 - Paris, 1796), and the preserved correspondence confirms their mutual respect and commitment to enrich the cultural life of their cities. From the transcripts of Bajamonti's drafts of letters addressed to Luka (kept today in the Bajamonti Archive of the AMS, sign. XII/A, Koncepti korespondencije)5, we can learn a great deal about the origin and the performance of the Bajamonti's Mass for the Dead (Messa da morto) in F major for male choir, soloists and orchestra, composed in May 1787, on the occasion of preparations for the solemn memorial service given by the Senate of the Dubrovnik Republic in the Cathedral in honor of Ruđer Bošković. The score reflects Bajamonti’s evident enthusiasm for Boškovićs work, which marks a distinct period in the history of natural sciences.

\footnotetext{
3 The Kaznačić legacy in the Archives of the Croatian Academy keeps some of Bošković's letters, among others those addressed to Luka Sorgo. See Archives of the Croatian Academy, Fond Kaznačić, XV 2/I-85, Bošković's letters to Luka Sorgo, 1780, Zagreb.

4 Bajamonti was engaged in music in many ways, not only as a composer, music teacher and Kapellmeister at the Split Cathedral (1790-1800), but also as a reproducer, folk music transcriber and musical theorist and author of the first encyclopedically conceived dictionary of music compiled in Croatia, with three hundred entries from the field of musical theory and organology. See Ivana Tomić Ferić, Julije Bajamonti (1744.-1800.): Glazbeni rječnik [Julije Bajamonti (1744-1800): Dictionary of Music] (Zagreb: HMD, 2013).

5 The correspondence kept in the AMS is divided into two groups: group A (Julije Bajamonti's Archive in AMS, sign. XII/A, Correspondence Drafts) contains the drafts of letters Bajamonti sent to others, while group B (Julije Bajamonti's Archive in AMS, sign. XII/B) includes letters sent to Bajamonti by others. Correspondence from group B is partially arranged and classified and carries the signature XII/B with an additional number of the folder in which the letters are stored from individual subgroups (for example, the correspondence between Miho Sorkočević and Bajamonti has the signatures XII/B-111-1 and XII/B-111-2). There is, however, a considerable problem with the part of the archive that Bajamonti used for his debates and as notes, so the letters of some people to Bajamonti remain unarranged and scattered across different parts of the archive. In order to complete the list of preserved letters, it is necessary to mark the pages of the entire material and compare it with data from existing studies. This way we will be able to reveal which letters actually exist and whether there are any deviations in relation to the existing cataloguing of the archives. This is one of the goals of the announced project GIDAL IP-2016-06-2061 (acronym for the four-year scientific musicological project Musical Sources of Dalmatia in the Context of Central European and Mediterranean Music Culture from the $18^{\text {th }}$ to the $20^{\text {th }}$ Century), led by the author of this text. For the purpose of this study, we used archival material from group XII/A (Bajamonti's drafts) and from XII/B-111 (Correspondence Miho Sorkočević-Julije Bajamonti).
} 
After the death of the great scholar in 1787, Luka Sorkočević (responsible for the musical aspect of the memorial service) approached Bajamonti (then serving on the island of Hvar) and asked him to send a commemorative requiem from his own musical archive. The Dubrovnik composer sought a vocal mass for the dead with instrumental accompaniment that he would be able to prepare in time for the performance at the Dubrovnik Cathedral. From his request and Bajamonti's response, it is possible to observe the state of church music in Dalmatian cities in that time, especially in Dubrovnik and Split. Bajamonti, in fact, did not have any appropriate requiem in his collection, and only managed to find two masses for the deceased "in the Franciscan style, without instrumental accompaniment," probably simple masses for two voices rhythmized in the manner of cantus fractus, which in his opinion did not fit the intended purpose. However, he knew Pellizzari's requiems and considered them appropriate, but they also lacked instrumental accompaniment. ${ }^{6}$ For this reason, he decided to compose a requiem himself, grateful that he had been given the opportunity, in the absence of other masses, to present his work in honor of the "immortal" Bošković. Wanting to win the favor of the Dubrovnik nobility through Luka's support, he completed the requiem in a short time: in the first letter of May 11, 1787, he says that he had started composing, and less than two weeks later, in a letter of May 23, he proudly states that he is waiting for the occasion and favorable weather conditions to send the completed composition in time (see Appendix 1 and 2). Assuming that the musicians in Dubrovnik would be engaged in the premiere performance of his piece, Bajamonti, along with the score, sent instructions to the performers, accompanied by a commemorative sonnet, which he wrote in Ruđer Boškovićs honor. Performance instructions can be viewed as a kind of preface to the work: Bajamonti decided to compose a mass for two tenor voices and one bass, which was a common ensemble of church singers, and along with string instruments intended to introduce wind instruments (since there were some in Dubrovnik), but if necessary, the composition could also be performed with strings only, with two violins or the organ taking the wind parts. ${ }^{7}$

\footnotetext{
6 Bajamonti's musical activity started very early in his youth when he began to acquire basic knowledge in musical theory and musical skills in his native Split by studying with the then Kapellmeister of the Split Cathedral Benedetto Pellizzari (?-1789), an Italian from Vicenza. Pellizzari was doubtlessly the most popular and most fruitful composer on the eastern shores of the Adriatic in mid- $18^{\text {th }}$ century. About 400 of his compositions are spread throughout music collections from Koper (Capodistria) to Kotor (Cattaro), but are largely kept in Split, where he was active from 1753 and was mainly attached to the church with teaching obligations. See Ivana Tomić Ferić, "Cultural contacts between the two shores of the Adriatic in the second half of the eighteenth century, as exemplified in the works and correspondence of Julije Bajamonti," in L'Adriatico tra sogno e realta, edited by Persida Lazarević Di Giacomo and Maria Rita Leto (Alessandria: Edizioni dell'Orso, 2019), 229-269.

7 In his letters, Bajamonti does not list the entire ensemble, but only mentions violins and the organ, strings and winds. The string ensemble is evident from the score, and when listing wind
} 
He intended to compose the choral parts for moderate vocal range and performance requirements, as he did not know the vocal competences of the singers. Therefore, his instructions explain that, in the absence of soloists for each part, singers of the nearest vocal range can perform instead, i.e. the bass or the first tenor can sing most of the solo sections of the second tenor and vice versa.

Unfortunately, the original score of Requiem was not preserved in full in the Musical Archive of the Split Cathedral (GASK, international archival signature HRSk): today, we can find only the incomplete score, parts and a transcript of Sanctus and Agnus Dei (identified by Vito Balić during the most recent examination of the GASK). ${ }^{8}$ There is no composition title on the cover page of the score and on the parts that are in Bajamonti's handwriting. There is only a dedication on the cover page: "Per le solenni esequie / decretate dal Senato di Ragusa / a suffragio dell'anima dell'immortale / ab. Boscovich [For the solemn memorial service / ordered by the Senate of Dubrovnik / for the rest of the immortal soul / of abbot Bošković]."

From the musical perspective, the score confirms Bajamonti's interest in local folk music, and with its simple homophonic structure is a counterpoint to pieces he had written to Metastasio's verses, which show influences of contemporary trends of Italian opera. The musical form follows the form and content of the mass text, and the musical figures reveal a good connoisseur of Pellizzari's music and a

instruments (oboe, flute, horn, trumpet), the composer considers the performance possibilities in Dubrovnik. From the first page of the score, we can clearly see the instrumental ensemble: first and second violin, viola and string bass, as well as two oboes, which may be replaced by two flutes and two horns accompanied by an organ that contains only a figured bass part (see Appendix 2, A copy of Bajamonti's draft).

8 The incomplete score (HR-Sk-V/55:1, $30.4 \times 22.6 \mathrm{~cm}$ ) is written on a sheet of 10 -stave music paper and consists of unbound bifolia (8 pages). Only the first two bifolia (16 pages), up to the $43 \mathrm{rd}$ bar of Kyrie, have been preserved. The first page of the score bears the remark "Incontrata, $e$ trovata completa" by an unidentified archivist, according to which it is clear that the GASK had the full score of the Requiem until an unidentified point in time. The movements Sanctus and Agnus Dei ("miscelanea", HR-Sk-XCIX/1674:201c) are added to the collection in three three-part sections in the form of a choral score along with a thorough bass part. There are 16 preserved parts (HR-Sk-V/55:2-17; only the viola part is missing), and they are written on the same type of paper in three different manuscripts. The score, including bass, horn and string bass, are in Bajamonti's handwriting, but without the name of the composition or instrument and without the signature. Two tenor and two violin parts were written in a handwriting resembling Bajamonti's with the handwritten title of the composition and the author's name ("Messa da morto a 3 voci con stromenti" or "Messa de' morti a tre voci con stromenti" / "Del Nob. Sig: D:r Giulio Bajamonti") and the full name of the part, but without mentioning Bošković. The handwriting of two other violin parts (HR-Sk-V/55:13,15) are slightly different. The handwriting in the remaining parts is noticeably different. While one possible explanation is that someone helped Bajamonti write these parts, it is also possible that the Requiem was performed on different occasions, for which other Kapellmeisters also copied the parts. For the transcribed movements Sanctus and Agnus Dei from the Requiem, there is no doubt that they were repeatedly performed. See Ivana Tomić Ferić, Vito Balić (Eds.), Requiem for Ruđer Bošković (Sheet Music: Musical sources of Dalmatia, Vol. 3) (Split: Arts Academy, University of Split, 2019). 
specialist in composing church music. Having completed the mass and the sonnet, Bajamonti asked Count Lukša, as he intimately used to call the older brother Sorgo, to send him all the commemorative speeches that would be published in Dubrovnik on the occasion of Bošković's death (see Appendix 3). However, despite sending the score and the sonnet to Dubrovnik via Sergeant Resićs felucca on June 1, 1787 (as reported by Luka Sorkočević in a letter dated June 2 of the same year) ${ }^{9}$, Bajamonti's composition did not arrive in time to be performed at the solemn memorial service, as his letter of July 19 reads (see Appendix 4). Nonetheless, it was performed a little later (June 25), at a private concert, probably at the palace of the Sorkočević family in Komolac, in Rijeka Dubrovačka. After composing the Requiem, Bajamonti began writing his Eulogy for Ruđer Bošković, which he completed only in 1789 and published it with the support of Miho Sorkočević, first in Dubrovnik (Elogio del Boscovich) ${ }^{10}$ and then a year later in Naples (Elogio dellabate Ruggiero Giuseppe Boscovich). ${ }^{11}$

Wanting to be different from others, Bajamonti studied in detail all the eulogies written in Boškovićs honor that he received from his Dubrovnik friends, and wrote a lot about his own eulogy in the letter drafts (he gave the most complete review to Miho Sorgo in a letter dated August 2, 1789). ${ }^{12}$

As one of the most prominent citizens of Dubrovnik, who performed important duties in the service of the Republic and was a member of the Roman Academy of Arcadia, Miho Sorgo had a cordial friendship with many European intellectuals, especially with Paduan naturalist and travel writer Alberto Fortis (Padua, 1741 - Bologna, 1803), the author of the popular travelogue Viaggio in Dalmazia (Venice, 1774). Fortis became famous in Europe for showing the world the previously unknown treasure of the eastern Adriatic coast, and he maintained contact not only with Sorgo but also with other Dalmatian writers and philosophers. With Bajamonti he discussed many topics and details-biographical, scientific, political, social, economic and cultural-constantly presenting and exchanging their own and others' discussions and books. Their correspondence shows the penetration and permeation of Enlightenment ideas on the Adriatic coasts in mid- $18^{\text {th }}$ century, reflecting the universality of the spirit and the lifestyles of its authors. In collaboration with Miho Sorgo, they shared in their letters thoughts

\footnotetext{
9 "A 2 Giugno 87. Al C(onte) Sorgo ò dato avviso d'averli spedita la messa da morto colla filucca del serg(en)te Resich partito ieri [...]”, AMS, XII/A, p. 15 (Letter from June 2, 1787).

10 The Institute for Historical Sciences in Dubrovnik - Croatian Academy of Sciences and Arts, Mescolanze raccolte da Giovanni de Bizzarro, Vol. I, t. 6. Elogio del Boscovich. Ragusa: Andrea Trevisan, 1789, Dubrovnik.

${ }^{11}$ Elogio dell'abate Ruggiero Giuseppe Boscovich (Napoli: Presso Donato Campo, 1790), VIII+40 p., kept in the National and University Library in Zagreb, R II F-40-167; Biblioteca nazionale Vittorio Emanuele III - Napoli, Sala 6a Misc. A.25/12.

12 See the full transcript in Appendix 5.
} 


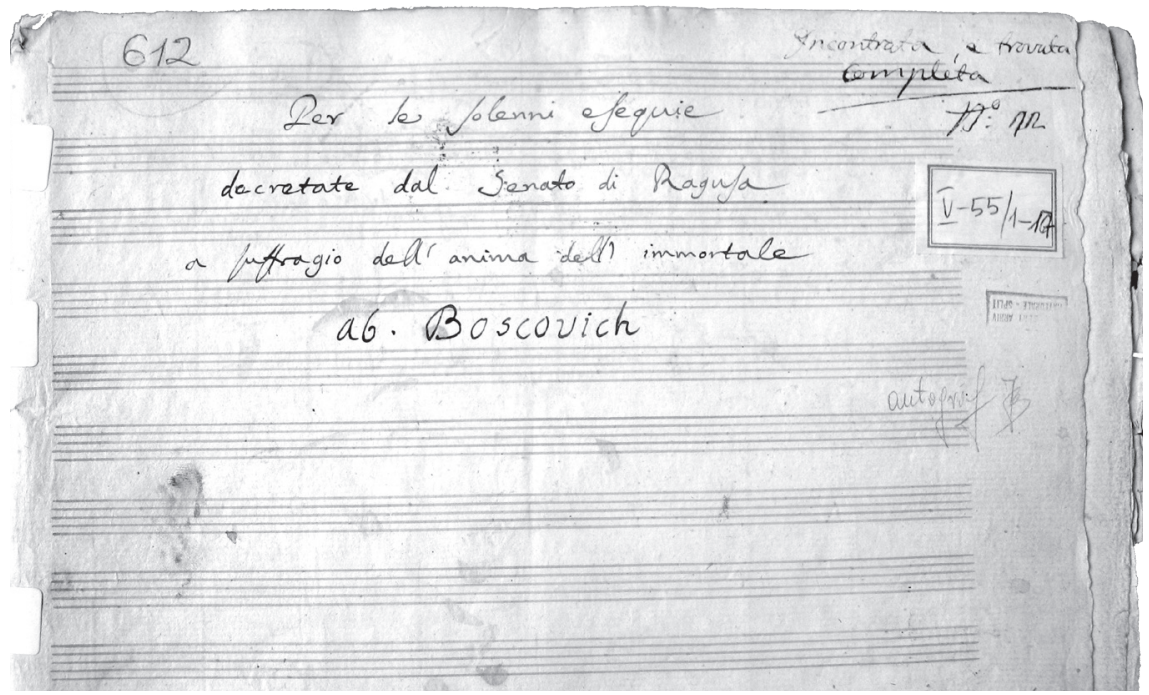

Figure 1. Bajamonti's dedication to Bošković, autograph, the first page of the incomplete Requiem score. HR-Sk-V/55:1.

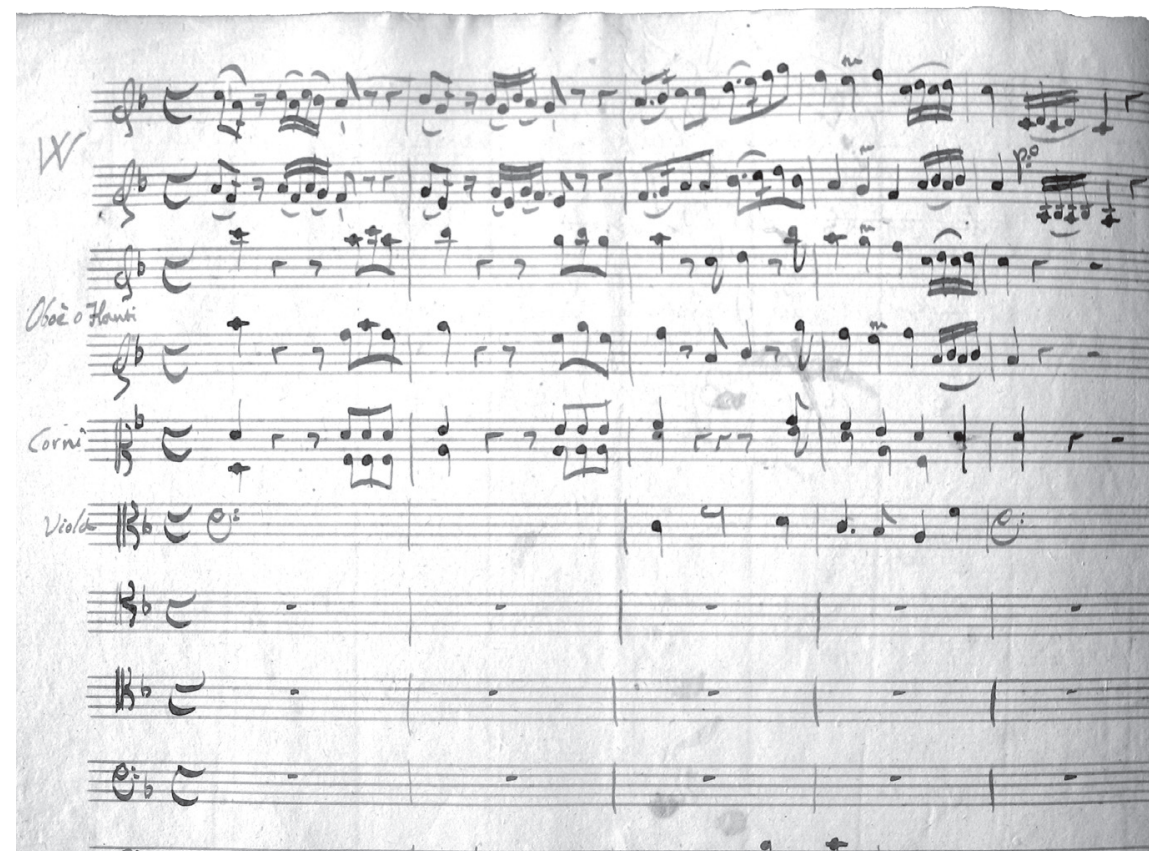

Figure 2. The beginning of Bajamonti's Requiem, autograph, the second page of the incomplete score. HR-Sk-V/55:1. 
about literature, poetry, music, friends and news from Dubrovnik, Split or Hvar. All of them respected and honored each other, continually sharing, reviewing or commenting on their own and others' studies and ideas (see Appendix 6, a copy of Miho Sorkočevićs letter to Bajamonti). In honor of Fortis, Miho Sorgo prepared and published in 1790 a poetic composition Albertus Fortius Rhacusa discendens, with Bajamonti's Italian translation.

The writing style of this Croatian follower of the Enlightenment is modern and close to the level of European classicist thoughts, as is evident from his distancing from scholastic philosophy and its later branches, from the pathos similar to baroque tradition and oriented toward practical reflection in which philosophy is linked to politics in order to create a rich, modern nation. In the field of music, the compositions of Bajamonti and Luka Sorgo fit into a compositional-technique framework of the period of breaking from the old, Baroque style into a new, Classical one, and were an integral part of the creative practice of the time. Bajamonti's musical legacy is quite extensive and includes about 230 sets or fragments of various pieces, where secular forms are less represented (arias, duets, choir songs and chants, symphonies), while most of the opus contains church music (motets accompanied by the organ or chamber orchestra, masses, passions, requiems, responsorial psalms, anthems, Te Deums). The oratorio La Traslazione di San Doimo from 1770 is the first Croatian oratorio but also one of the most significant pieces of Croatian $18^{\text {th }}$-century music, which synthesizes Bajamonti's historical research, his literary work, composing and performing inspirations. In his youthful compositions (mostly sacred), he was under a strong influence of Pellizzari, who built his opus on a rather unproblematic link between the characteristics of the Baroque and the pre-Classical style. ${ }^{13}$ Bajamonti was much more progressive, but he made a complete departure from Pellizzari only after he was acquainted with the musical life and culture in more developed centers of music of Padua and Venice in the course of his studies. In Italy, he had the opportunity to meet, hear, analyze and transcribe valuable achievements of Italian and other composers, especially German ones (e.g. Paisiello, Stamitz, Mozart, Glück), who essentially determined his own creative expression. He brought numerous scores from Italy, both his own and transcripts or adaptations of other works, which prove that he was relatively up to date and fairly open to formal innovations that fluctuated on the western coast of the Adriatic. ${ }^{14}$ By emphasizing the Italian influence and the use of Pietro Metastasio's verses in Bajamonti's compositions, Belamarić dares to claim that Bajamonti's work will have its real frame only in a formal style

\footnotetext{
${ }^{13}$ Miljenko Grgić, "Dr. Julije Bajamonti, glazbenik [Dr. Julije Bajamonti, the musician]," in Split's polymath Julije Bajamonti, edited by Ivo Frangeš (Split: Književni krug, 1996), 87-117.

${ }^{14}$ For more details about the pieces from Padua and Venice handwritten by Bajamonti (unsigned) presenting the musical characteristics and phraseology of Italian music authorities, whose work the polymath from Split studied, see Grgić, “Dr. Julije Bajamonti,” 90.
} 
confrontation with related works of a relatively broad Italian composing front of his age. ${ }^{15}$ Moreover, he believes that instead of listing his authenticated pieces, it would be much more useful to study the share of Bajamonti's interventions and digressions from patterns in adaptations of the works of Guglielmi, Anfossi, Sacchini, da Capua and other Italian masters. ${ }^{16}$ Only through a comparative study would it be possible to evaluate the influence of his immediate environment-more noticeable in his late creative period when, inspired by the pre-Classical style and compositions of Luka Sorgo, Bajamonti turns to folklore and elements of simple folk dances-against inarguable Italian formal and stylistic references that he might have taken or copied in his compositions, be it intentionally or unintentionally.

Luka Sorgo's symphonies are also marked by the spirit of early Classicism, in fact they are the first and most authentic testimonies of Croatian pre-Classical musical thought-but there are some differences in comparison with the composing style of his younger colleague. While Bajamonti was powerfully influenced by Venetian opera, just as Split and Dalmatia were oriented to Venice as their main focus in culture, Luka, as a representative of the Dubrovnik Republic, which communicated with various centers and milieus, was more oriented to wider musical and cultural currents, the kind that could be felt in Rome, Milan, Vienna and in particular the innovations that Glück and his Viennese and Parisian works had introduced. ${ }^{17}$ We can learn about Sorgo's personal contacts with Glück, as well as Metastasio, Haydn and other leading composers and artist of the time, from the diary that he wrote during his journey to Vienna and his return to Dubrovnik. Thanks to this document, we can follow his experiences in Vienna, where he described, above all, a series of encounters and events related to politics and diplomacy, but also some related to culture and music, as well as other social events. ${ }^{18}$ It was precisely this connection he maintained with prominent individuals, scholars and artists that essentially contributed to his Enlightenment tendencies.

Like his older brother, Miho Sorgo also developed through different diplomatic tasks for the Dubrovnik Republic a dense network of contacts with writers interested in the history and customs of Slavs-from Italian authors Melchiore Cesarotti and Alberto Fortis to Spanish theater and music writer Esteban de Arteaga - as well as Bošković, whose oeuvre forms a separate and respectable

\footnotetext{
15 Joško Belamarić, "Metastasijevi stihovi u skladbama iz Glazbenog arhiva splitske katedrale [Metastasio's verses in compositions kept in the Musical Archive of the Split Cathedral]," Arti musices 11 (1980): 157-201.

16 Ibid., 167.

17 Vjera Katalinić, Sorkočevići dubrovački plemići i glazbenici [The Sorkočevićs, the Nobles and Musicians from Dubrovnik] (Zagreb: Muzički informativni centar Koncertne direkcije Zagreb, 2014), 151-153.

18 The diary is kept in the Dubrovnik State Archive. For more details about its content, see Katalinić, Sorkočevići, 48-71.
} 
part in the whole history of natural sciences among Croats. It is interesting to note that, besides written communication, Luka Sorgo and Ruđer Bošković had the opportunity to meet Pietro Metastasio in person, with many mutual compliments and praise. Presenting one of Metastasio's letters to Bošković, sent from Vienna to Paris on August 18,1781, Katalinić highlights a section where the Italian poet praises Luka Sorgo's refinement and erudition, his manners, and noble and rational behavior with which he won over the Viennese nobility. ${ }^{19}$ It can be assumed that Count Lukša shared his positive impressions about the "sincere, natural and clever" 20 Metastasio with his colleague from Split, especially taking into consideration the series of scores Bajamonti composed to his verses, which are stored in the Musical Archive of the Split Cathedral. In the case of all the historical figures presented here, we can conclude that they constantly broadened the narrow frames of understanding life and the world around them. With their creative and social activities, open-mindedness and sensitivity to cultural and spiritual values, they strongly represented the general spirit of the Enlightenment. It seems that those thirsting for scientific and cultural progress made their cities open to foreign artist, musicians, theatre ensembles, scholars, naturalists and travelers, who enriched the cultural life of the Dalmatian littoral at the end of the Enlightenment period.

By establishing connections and contacts with foreign individuals, circles and institutions, and fostering sensitivity to their own cultural and spiritual values, Julije Bajamonti, brothers Luka and Miho Sorgo and Ruđer Bošković combined in their work and activities all the important features of 18th-century local and European culture. With their refined views and beliefs, their eminent knowledge and artistic dedication, they devoted themselves and their work to the mission of the Enlightenment and remain to this day a model of noble and self-sacrificing modesty, but also of lasting value in shaping Croatia's cultural identity and its international confirmation.

The relations of Croats with other Western European countries in the $18^{\text {th }}$ century were prolific and diverse, and their revelation evokes the undeniable values of national achievements in various branches of science and art. They testify to the greatness of "small peoples," to the development of cultural identity as a result of the intertwining of different traditions, civilizational circles, opinions and influences. In the sphere of musical history, it is difficult to estimate how strong the centripetal force was with which prominent European centers (e.g. Venice, Padua, Rome, Naples, Vienna) tinged musical activity in Dalmatia, but it is more than certain that the encounters, permeation and transformation of cultural traditions happened directly-by direct transmission of tradition and influence-from teachers to students and indirectly through the exchange of instruments, scores, repertoire and music

\footnotetext{
19 Ibid., 27-35.
}

${ }^{20}$ Ibid., 29. 
books. That is why the research presented here, analyzing the concrete examples of intercultural interactions through selected parts of Bajamonti's, Sorkočevićs and Bošković's legacy in the wider musicological, cultural and political context has current relevance.

By building a recognizable distinctiveness, Croats, as "the antemurale of Europe," contributed to its spiritual communion. Examples of this togetherness and cultural synthesis are found in Croatian Petrarchism, Latinism, Dantology, but also in the ideas of the Enlightenment followed and developed by all these great individuals whose activities we discussed. 


\section{Primary sources:}

Archeological Museum in Split (AMS): Archives of Bajamonti's legacy, XII/A: 1-228, Correspondence Drafts, 1787-1789, Split.

Archeological Museum in Split (AMS): Archives of Bajamonti's legacy, XII/B-111-3, Correspondence Miho Sorkočević - Julije Bajamonti, 1779, Split.

Musical Archive of the Split Cathedral (GASK): HR-Sk-V/55:1, Julije Bajamonti, Requiem for Ruđer Bošković, 1787, Split.

Archives of the Croatian Academy of Sciences and Arts: Fond Kaznačić, XV 2/I-85, Boškovićs letters to Luka Sorgo, 1780, Zagreb.
The Institute for Historical Sciences in Dubrovnik - Croatian Academy of Sciences and Arts, Mescolanze raccolte da Giovanni de Bizzarro, Vol. I, t. 6. Elogio del Boscovich, Ragusa: Andrea Trevisan, 1789, Dubrovnik.

National and University Library in Zagreb, R II F-40-167, Elogio dell'abate Ruggiero Giuseppe Boscovich, Napoli: Presso Donato Campo, 1790, Naples.

Biblioteca nazionale Vittorio Emanuele III Napoli, Sala 6a Misc. A.25/12, Elogio dellabate Ruggiero Giuseppe Boscovich, Napoli: Presso Donato Campo, 1790, Naples.

\section{References:}

Belamarić, Joško. "Metastasijevi stihovi u skladbama iz Glazbenog arhiva splitske katedrale." Arti musices 11 (1980): 157-201.

Duplančić, Arsen. "Ostavština Julija Bajamontija u Arheološkom muzeju u Splitu i prilozi za njegov životopis." In Split's polymath Julije Bajamonti, edited by Ivo Frangeš, 13-80. Split: Književni krug, 1996.

Grgić, Miljenko. "Dr. Julije Bajamonti, glazbenik." In Split's polymath Julije Bajamonti, edited by Ivo Frangeš, 87-117. Split: Književni krug, 1996.

Katalinić, Vjera. "Korisne veze: Luka Sorkočević-Ruđer Bošković-Pietro Metastasio." Arti musices 46/1 (2015): 27-35.

Katalinić, Vjera. Sorkočevići dubrovački plemići i glazbenici. Zagreb: Muzički informativni centar Koncertne direkcije Zagreb, 2014.

Stojan, Slavica. "Kulturni krug Luke i Miha Sorga (Sorkočevića): Glazbenici, pjesnici i diplomati." Anali Dubrovnik 54/2 (2016): 247-262.

Tomić Ferić, Ivana. "Cultural contacts between the two shores of the Adriatic in the second half of the eighteenth century, as exemplified in the works and correspondence of Julije Bajamonti." In L'Adriatico tra sogno e realta, edited by Persida Lazarević Di Giacomo and Maria Rita Leto, 229-269. Alessandria: Edizioni dell'Orso, 2019.

Tomić Ferić, Ivana. Julije Bajamonti (1744.1800.): Glazbeni rječnik. Zagreb: HMD, 2013.

Tomić Ferić, Ivana. "Suradnja s Julijem Bajamontijem." In Luka \& Antun Sorkočević, diplomats and composers, edited by Pavica Vilać, 233-263. Dubrovnik: Dubrovnik Museums, 2014.

Tomić Ferić, Ivana. "Susreti prekojadranskih kultura u razdoblju klasicizma: Bajamontijeve glazbene i izvanglazbene veze." Bašćinski glasi 13 (2017/18): 73-121.

Tomić Ferić, Ivana, Balić, Vito (Eds.). Requiem for Ruđer Bošković. Sheet Music: Musical sources of Dalmatia, Vol. 3. Split: Arts Academy, University of Split, 2019.

Wolf, Larry. Venice and the Slavs. The Discovery of Dalmatia in the Age of Enlightenment. Stanford: Stanford University Press, 2001. 


\title{
APPENDICES \\ (Transcripts of Bajamonti's letters/drafts)
}

\author{
Appendix 1 \\ Bajamonti's letter to Luka Sorgo, \\ May 11, 1787, XII/A, AMS, p. 3-4
}

Al s(igno)r Conte Luca Sorgo. A Ragusa.

Da Lesina 11 Maggio 87.

La sua lettera dei 24 Aprile pross(imo) pass(ato) më pervenuta solam(en)te due giorni fa col mezzo di un venditore di bagatelle, il quali dice di averla ricevuta costà dal sig(no)r Angiolino sonatore. Non avendo io messe da morto fra le mie carte di musica, ho usato ogni diligenza per trovarne qui presso qualcheduno altro, ma non ne ho trovato che due, di gusto zoccolante, senza strumenti, e da non cantarsi a unianima matematica. Quelle del maestro di capella di Spalatro, che per'altro sarebbone ben opportune mancano pur dell'accompagnamento istrumentale; perché essendo colà determinato il prezzo de' mortorj in musica, il quoziente de' preti cantori patirebbe qualche sottrazione alorché s'avesse a pagare anche qualche laico sonatore. Quanto al conte Simunich, dilettante di violino, a di musica galante, io lo credo tanto lungi dal tenere fra la sue carte una messa da morto, che par quanto io abbia con lui amicizzia, e di famiglia e di persona, temerci che se la pigliasse meco se io giungesi a fargli una ricerca di questo genere. In tale stato di cose, e non essendomi possibile per la contrarietà de' tempi di farle avere una pronta risposta sopra ciò ho pensato di scrivere io se stesso una messa da morto, che quando non mi si frappongano straordinarj imbarazzi, spero di compire in pochi giorni. Non essendomi nota la portata gutturale di cotesti sacri cantori, penso di attenermi a una misura media, e di comporre l'armonia a due tenori e un basso che sono le voci più ordinarie. Perciò che riguarda l'orchestra, sò che costà oltre gli strumenti d'arco non mancano quei da fiato, i quali io penso di far'entrare nella mia composizione, in modo però che possa eseguirsi anche coi soli violini. La fattura è già incominciata, e forse il vento contrario, che secondo tutte le apparenze vuol durare ancora, farà ch'io la finisca prima di averle potuto mandare altra risposta. Ma intanto io apparecchio questo foglio che spedirò colla la prima occasione, perché Ella veda se mai Le poteste comodare, in mancanza di altre messe da morto, di servirsi della mia; la quale se per l'ostinazione de' tempi non arrivasse costà entro a questo mese, certamente non dovrebbe mancare di arrivarvi nel principio del prossimo venturo;il che forse ancora potrebbe convenire alle giuste e degne 




a Jua Jottera dei $p_{4} 4$ aprile proff paff. me pervenuela solam the jorni fa ex"

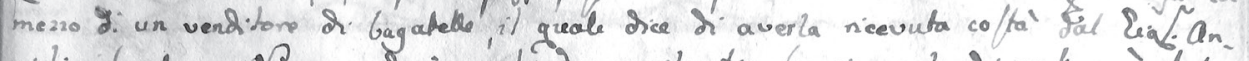

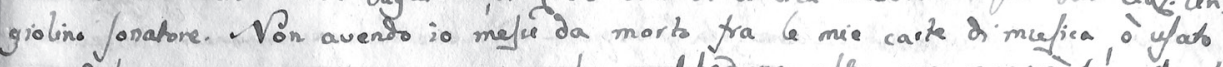
- gni Xigena per trovarne gei prefo gualchedueno altro ma non nes trovato che

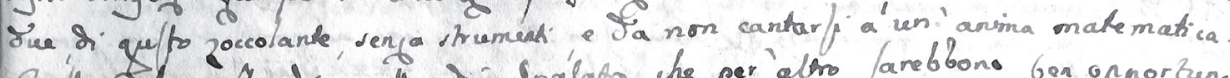

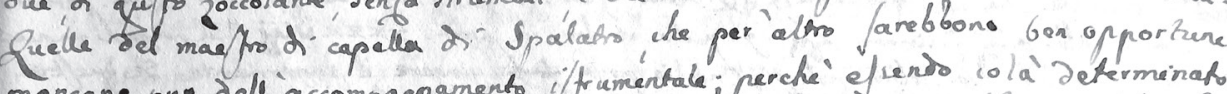
mancane pur dell accompagnamento iffumentale; perche ef uento cola' determinato

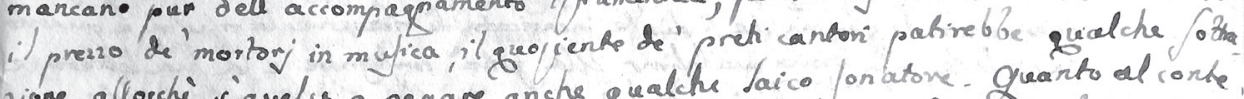

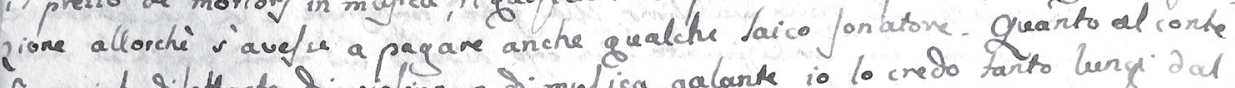


venere fra la Jue carke una malsa da morto che per geanto io ab bia cor lus" amicrizia ed famiglia ed perfora, hemens che de fa pialiass mees, de io

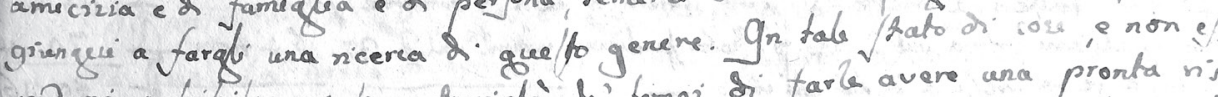

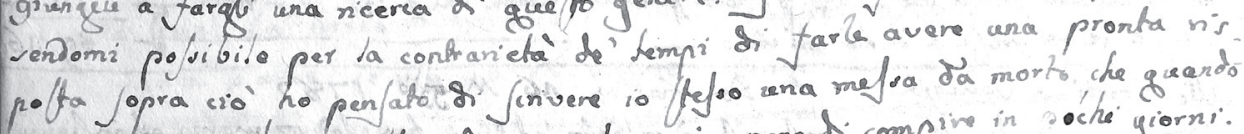

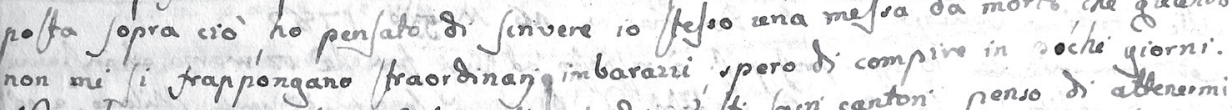



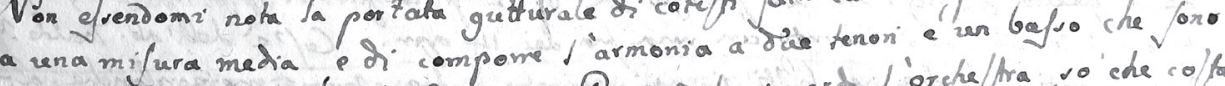





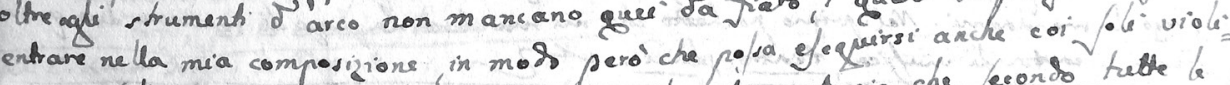

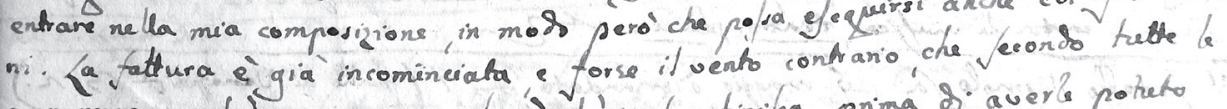
apparenge unol durane ancora tara' ch' io la finigsa prima di averls poteto

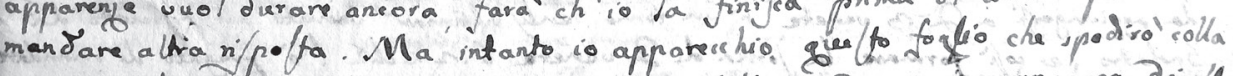
prima occatione, perche Ella veda se mai le poteff comadare, mancanza 2 , allue

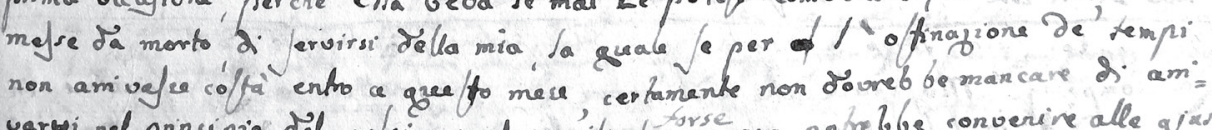

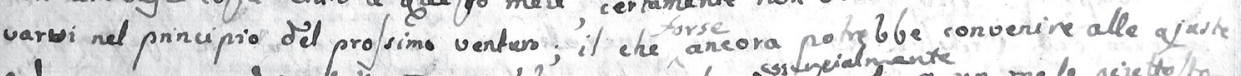

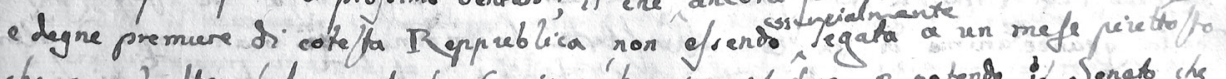

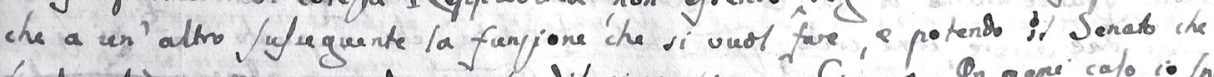

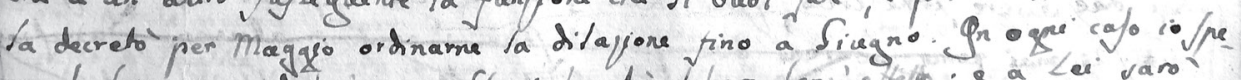

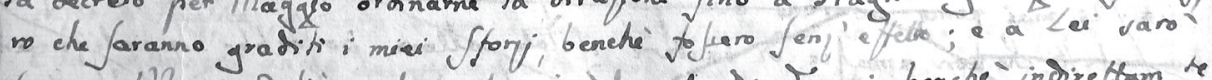

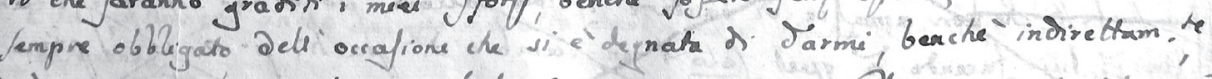

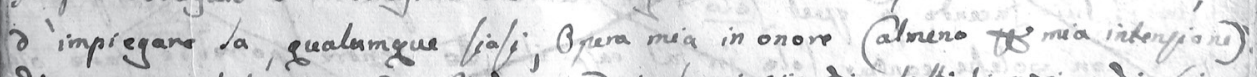

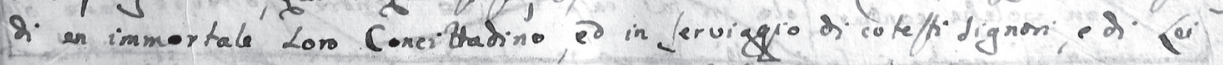



A copy of the draft of Bajamonti's letter to Luka Sorgo about his Requiem, May 11, 1787, AMS, XII/A, p. 3-4 
premure di cotesta Reppublica, non essendo essenzialmente legata a un mese piuttosto che a un altro susseguente la funzione che si vuol fare, e potendo il Senato che la decretò per Maggio ordinarne la dilazione fino a Giugno. In ogni caso io spero che saranno graditi i miei sforzi, benché fossero senzeffetto; e a Lei sarò sempre obbligato dell'occasione che si è degnata di darmi, benchè indirettam(en)te, d'impiegare la, qualunque siasi, Opera mia in onore (almeno p [er] mia intenzione) di un immortale Loro Concittadino ed in serviggio di cotesti Signori, e di Lei in particolare, a cui rispettosamente mi prottesto...

\section{Appendix 2 \\ Excerpt from Bajamonti's letter to Luka Sorgo, May 23, 1787, XII/A, AMS, p. 4-5}

Al Sig(nor) Co(nte) Luca Sorgo a Ragusa.

Da Lesina 23 Maggio 87.

La Composiz(io)ne Musicale che ho l'onore di trasmettere a Lei siccome incaricato dell'Orchestre p(er) i solenni funerali da farsi costà in suffraggio della grande anima di un loro iliustre Cittadino, in mancanza d'altri pregi dee avere, como credo, q(ue)llo della facilità che appunto da Lei si cercava. Se mai in alcuna delle parti non vi fosse cantore che amasse di restare isolato, voglio dire di cantare i solo alloro potrà forse supplire un cantore di unialtra delle parti: cosi un primo tenore o un basso oltre ai solo proprj potrebbe fare $i$ solo del tenore secondo, e questo i solo del primo o del basso: che se q(ues) to cambio non potesse aver luogo in tutti i solo potrà certam(en)te effettuarsi nella maggior parte de med(esi)mi. Perciò che riguarda glaccumpagnam(en)ti, so che costà o hanno stromenti da fiato oltre a q(ue)lli darco, e credo che non ci sarà bisogno di sostituz(io)ni: a ogni modo se mai p(er) qualche accidente mancassero gli Oboè, o i Flauti, o i Corni, e la Tromba, si potrà ne' passi obbligati supplire con due Violini, o coll'organo. Ora non manca altro che 'l tempo favorevole e una occasione o diretta, o mediata p(er) farle giungere lo spartito di q(ues)ta Messa che pron-tiss(i)mo, e che desidera di presentarsi a Lei, e col di Lei mezzo a cotesti Sig(no)ri tutti, presso a' quali la prego di conciliare al med(esi)mo quella indulgenza chesso non merita $p(e r)$ altro se non per la buona intenz(io)ne dellautore, il quale pieno di venerazione e per il sublime ed immortale Boscovich, i per tutti cotesti Signori, con particolare stima, ed altamamento si protesta... 


\section{Appendix 3 \\ Excerpt from Bajamonti's letter to Luka Sorgo, \\ May 24, 1787, XII/A, AMS, p. 5}

Al C(onte) Luca Sorgo. A Ragusa.

Da Lesina 24 Maggio 87.

Alla messa aggiungo un sonetto, non so con qual fronte! Im(m)aginandomi le belle ed eccellenti cose che si saranno fatte da cotesti squisiti poeti, io non dovea esporre niente del mio: ma la voglia di fare omaggio al gran Boscovich e alla sua patria, mi rende ardito. Io sono sicuro ch'Ella vorrà aver la bontà di mandarmi l'elogio e le altre composizioni prodotte in questa occasione, le quali cose tutte io spero di vedere colle stampe di costà...

\section{Appendix 4 \\ Excerpt from Bajamonti's letter to Luka Sorgo, July 19, 1787, XII/A, AMS, p. 14}

Al C(onte) Luc'Antonio Sorgo a Ragusa.

Da Lesina 19 Luglio 87.

Il mio Spalatrino che con buona ed onesta maniera Le si esibi di farmi tenere le di Lei lettere, se è burlato di Lei, e di me, e per colpa del medesimo io non ho ancora potuto sapere se la mia messa sia costà giunta a tempo per i funerali del Boscovich solamente dalla di Lei lettera de' 25 del prossimo passato Giugno prendo motivo di compiacermi che la detta mia fattura sia stata da Lei, e da cotesti altri Sig(no)ri accolta con bontà in un privato concerto. Con unialtra sua dei 26 detto ho ricevutto il complimento illirico-poetico della sorella del defonto allauttore del funebre elogio, e rendo le dovute grazie alla degna nutricia delle nazionali musi per la memoria che conserva di me. Ringrazio anche la Sig(nor) a Gozze di Lei nipote per il suddetto elogio mandatomi, ma non pervenutomi... 


\section{Appendix 5 \\ Excerpts from Bajamonti's letter to Miho Sorgo, \\ August 2, 1789, XII/A, AMS, p. 100, 101, 102}

(p. 100)

Al C(onte) Michele Sorgo a Ragusa

Da Les(in)a 2 agosto (1)789

Eccole di bel nuovo l'elogio del Boscovich ch'io ò creduto di migliorare. Possa il fatto corrispondere alla mia buona intenzione. Io l'aveva già scritto con uno scarso ajuto di materiali, e mera riuscito per verità troppo magro e meschino. Di cose d'altri sullo stesso argomento io non aveva veduto che l'orazione del Zamagna, e due brevi coserelle nel giornale di Vicenza. Mi mancava la maggior parte dell'opere del mio eroe non avendo io avute in mio potere che le poche datemi già dal S(igno)r di Lei fratello, e sono soltanto quelle ch'egli avea doppie fra tutte le altre da lui possedute. Non è già che io avessi voluto dare gli estratti di tutte, ma ne avrei potuto trarre varj sugosi cenni. Ora rileggendo la mia fattura ò creduto bene di esporre più chiaramente

(p. 101)

teoria boscovichiana dell'unica legge delle forze naturali: e a far ciò mi sono servito dell'opera sopra tale argomento, la quale ò presso di me. Ò aggiunto anche un cenno sopra le operette antiquarie del Boscovich. Sulla fede poi dal Ricca ò aggiunto la notizia di alcune cose che si leggono nelle illustrazioni boscovichiane sopra il poema dello Stay; e dell'aver il Boscovich nel suo viaggio astronomico per lo stato pontifizio scoperte alcune macchie di alcuni famosi matematici. Dal Ricca ${ }^{21}$ ò anche preso l'anedoto che il Boscovich fu creduto un mago dagli alpigiani in occasione del detto suo viaggio astronomico, e varie paricolarità che riguardano il nostro eroe da quando fu professore a Pavia fino al suo stabilimento in Francia, e dalla partenza sua da quel regno fino alla sua ultima malattia. Quanto alle cose dell'altra vita, non l'o levate interamente, ma mi par di averle moderate e poste in un aspetto meno urtante; poichè dove prima io aveva scritto assolutamente che l'anima di Boscovich passeggia di cielo in cielo, che va nel purgatorio di una stella o di un sole, ed altre si fatte impertinenze, ora comincio dallo scrivere che se ci fosse lecito di vedere nellaltro mondo forse potremmo dire varie belle e nuove cose, e in seguito dicendone io (non so se di belle o di brutte) sempre ci metto un forse un chi sa; e finalmente

${ }^{21}$ References to Francesco Ricca's Elogio storico dell' abate Ruggiero Giuseppe Boscovich (Milano: Nella stamperia di Giuseppe Marelli con licenza de’ superiori, 1789). 
quando sono al punto del purgatorio mi ravvedo e confesso di aver vaneggiato. Oltracciò per salvare qualche riguardo inquisitorio ò posto a piè della pagina ps., una nota o prottesta da buon cristiano facendo apparire buoni cristiani anche gli editori dellelogio. Che se ad onta di tutto ciò Ella trovasse ancora della stravaganza nelle mie fantasie, io ardirei di dire che un po' di stravaganza fa bene e si fa leggere più volentieri. Io scommetterei che la maggior parte di quelli che leggeranno (se ciò avverrà mai che vábbiano leggitori di sì fatta cosaccia) il mio elogio del Boscovich, proveranno minor noja quando saranno arrivati a forza di pazienza al viaggio della di Lui anima d'uno in un altro cielo, e di pianeta in pianeta e di cometa in cometa, di quello chè nell'altre più serie e più esatte parti dello scritto. Poichè abbiamo a quest'ora parecchi elogi di questo grande uomo, come s'avrebbe a distinguer il mio dagl'altri se non in grazia di qualche stravaganza? Benchè, a dir vero, cè per altro ne' tratti sospetti che un poco di poesia? Ora non abbiamo noi della poesia nelle prose de' piu celebri e grandi scrittori di eloquenza, e di filosofia cominciando da Platone e terminando nel Massillon? A ogni modo io mi rimetterò al giudizio di Lei e d'altri intendenti, nè mi dorrà d'esserne corretto anche un altra volta, anzi me ne pregierò. Del resto ò in parte levate e in parte modificate certe riflessioni troppo ricercate e poco spiritose ch'io aveva estese sopra l'imbecillità in cui cadde il Boscovich prima dellultima sua malattia. E finalmente per ciò che spetta a quanto scrissi

(p. 102)

in fine dellelogio sopra la stanchezza delle matematiche e sopra la sicurezza del Boscovich di non aver mai a restare oscurato dal confronto d'illustri successori, Ella forse, notando si fatti passi, à voluto tacciarmi di esaggerazione e adulazione: maio con sua pace (se mai Ella avesse presa la cosa per questo aspetto) io scrissi a quel modo di buona fede, e con intima persuasione che cosi sia e debba essere. Che v'abbia ormai dell'intermittenza nel fervore delle matematiche, mi pare che sia cosa di fatto. Che il Boscovich non debba restare oscurato da illustri successori, io lo credo detto con tutta moderazione, perchè io non dico già che non v'abbiano ad essere anche in avvenire de'grandi matematici, ma non credo che abbiano a far divenire picciolo il Boscovich, siccomesso nè il gran Newton non fecero diventar piccioli Euclide, Archimede o altri antichi.

S'Ella farà degna d'essere stampata costà la mia fatturaccia, il che lusingherebbe molto la mia ambizione, io suppongo che ci porrà il semplicissimo titolo: Elogio del Boscovich. Quando si dice Boscovich s'intende il grande, il famoso, il distinto chè appunto Ruggiero, non già Boxo o altri. Il luogo delledizione espresso nel frontispizio annunzierà essere questo fra gli elogj boscovichiani 
addottato dalla patria del lodato: onore ben grande pel lodatore. Alcuni passi che si leggono nell'introduzione o principio dellelogio testificheranno la stima e l'omaggio dell'autore verso i compatrioti del suo eroe e saranno la più naturale e la più ingenua di tutte le dedicatorie. Ancora io suppongo si adotterà un ortografia ben intesa, oggidi usata da più ragionevoli scrittori e stampatori, senza iniziali majuscole, fuorchè ne' nomi proprj e in principio di periodo, $e$ senza molte virgole. Finalmente la forma non molto grande delledizione donerà alla stessa uneleganza di più. Ma troppo grave torto ò fatto io a chi dirigerà cotesta stampa collestendermi tanto in cosi fatte minuzie.

I nostri complimenti chez vous. A quest'ora avrà ricevuto le ottave.

\section{Appendix 6 \\ Miho Sorkočević's letter to Bajamonti, October 23, 1779, XII/B-111-3, AMS}

Am(ic)o Stim(atissim)o

Per mancanza d'occasioni non ho prima d'ora risposto all'ultima vostra lettera, doppiamente cara per l'aviso che in essa mi date dellarrivo a cod(est)a parte del nostro Fortis; Egli è desiderato da tutti i suoi Amici, in particolare da me che godo in anticipazione, pensando al piacere che averò nel riattaccare la nostra conversazione; Solo temo che poiché esso passeggia le amene vie delle Città Italiane, con torvo ciglio, non abbia a corrucciarsi seriamente all'aspetto della mia Sparta. Dico questo per ischerzo, sapendo quanto esso è Filosofo, discreto, e grazioso in particolare colli amici; Credo che sia ito a trovarne ora uno a Imoski, che trovasi Proveditore; Salutatelo dopo che sarà disceso alla Marina, $e$ diteli che ho ricuperato le sue robbe che trovansi trasportate in mia casa. Ho pure una lettera per lui. Vi prego pure di riverirmi il Sig(nor)e D(otto)r Urbani, ed avermi in grado de vostri veri Amici

Rag(us)a 23 Ottob(r)e 1779

$D$ (evotissi)mo Aff(ettuosissi)mo Ser(vitore) Am(ic)o

Michele di Sorgo 
Am: frinó

Ler mancanza d'uccasiomi non bí prima dóra risporto all' uliima cortra lettera, doppiamente cara per laviso che ix essa mi date dell' amivo a cucl." parze del noitro Fortsi. Eghi é desiderato da tuti i fnoi Anvici, in particolare da me che godo in anticipar= ione, pensando at piacere che avero nel nouraccare la nostra Converrazione; Solo temo che porichè esso passeggra le amene vie delle Citri Grahiane, con = torw cighio, non ablia a corncuciansi seriamente all' aspero deha ma parizas. Fico quasto per ischerno, sapendo quanto esso e'Filosofo, disireto, e graziaso in partiolare coll amici; Credo che sia ito a truvarne ara uno a gmosali, che trovasi Provediture; Salutatelo dopo che vara' disceso ala olavina, e diteh che hi rimperato le sue che trovarsi traspostare in mi Casas. Bo pune una Cettera per lini. Si prego pume di riverirm if fig? D. Urfam; ed averm in gracio de votn veni Amià. Rag.23 Buob: 1719

Diñ Afgimo Rev: Am:

Slicbele di Sorgo

A copy of Miho Sorkočević’s letter to Bajamonti, October 23, 1779, AMS, XII/B-111-3

-36 - 


\title{
The birth of the Serbian national music project under the influence of diplomacy
}

\author{
Vesna Peno, Goran Vasin
}

The aspiration to take a general perspective of the development of Serbian church and art music in the $19^{\text {th }}$ century within the broader sociopolitical and cultural context implies, according to recent findings, revision of the accepted theses in music historiography. One such recent scholarly endeavor ${ }^{1}$ has shed new light on the circumstances in which the Serbian national music program was initiated in Vienna, primarily associated in the second half of the $19^{\text {th }}$ century with the name Kornelije Stanković (see Appendix, Figure 1). This paper also shows that the Serbian "Enlightenment" in music at the time of rising nationalism(s) could be considered in the context of actual diplomatic activities that the church and political exponents of Orthodox nations took in the Habsburg capital. Structurally, there are two narratives that eventually meet toward the end of the paper. The first is related to the introduction of polyphony in Greek liturgical practice in Vienna. This music novelty gave rise to conflicting opinions expressed in the diplomatic dispatches that the Patriarch of Constantinople, residing in Fener, exchanged with Serbian Metropolitan Josif Rajačić (see Appendix, Figure 2), a church representative of all Orthodox citizens in Vienna. The second narrative in this paper follows the role that protopresbyter Mikhail Fyodorovich Raevsky (see Appendix, Figure 3), an influential Russian diplomat in Vienna, played in the creation of Pan-Slavic, therefore also Serbian, cultural politics and national music tendencies. Rajačić and Raevsky played important, if not decisive, roles in the overall social matrix from which Kornelije Stanković - not by chance and not exclusively owing to his artistic talent-entered the Serbian music stage. For this reason, particular attention is paid to these two figures, although there was a pleiad of high-ranking individuals in the Serbian circles of the time who contributed to the development, direction

\footnotetext{
1 Vesna Peno, "O višeglasju u bogoslužbenoj praksi pravoslavnih Grka i Srba: teološkokulturološki diskurs [On harmony singing in the religious practice of Orthodox Greeks and Serbs: A theological-culturological discourse]," Muzikologija 17 (2014): 129-154; Vesna Peno, Pravoslavno pojanje na Balkanu na primeru grčke i srpske tradicije: između Istoka i Zapada, eklisiologije i ideologije [Orthodox Chant in the Balkans on the Examples of Greek and Serbian Traditions: Between the East and West, Ecclesiology and Ideology] (Belgrade: Muzikološki institut SANU, 2016).
} 
and promotion of creative endeavors of the young Kornelije Stanković. ${ }^{2}$ The final part of the paper shows in what manner Stanković was praised for his musical mission during his short life with global and national importance, of which he was adamantly convinced.

Liturgical and particularly the church-music circumstances of Orthodox Christians in Vienna gave birth to a rare uniformity in the 1840s. On one hand, three nations-Greeks, Serbs and Russians-who shared the same faith, but whose church institutions had been burdened by many serious ecclesiastical issues for centuries, ${ }^{3}$ found themselves in ecclesiastical unison. On the other hand, an untypical encounter of Orthodox citizens of Vienna, who in many aspects had more differences than they had in common, occurred through liturgical music. The reason for their coming closer together was the introduction of four-part choral music in two churches in Vienna: the Trinity Church and the Church of St. George. ${ }^{4}$ In the mid-1840s, representatives of church boards in these two Greek Church communities ordered, not by accident, four-part sheets of liturgical chants from then very popular court composers/musicians Benedict Randhartinger (Chaviara $\&$ Randhartinger, 1844) and Gottfried von Preyer (Nikolaidou \& Preyer, 1845). ${ }^{5}$ Their scores (see Appendix, Figures 4 and 5) ${ }^{6}$ were performed by Austrian singers of the Vienna Opera, under the baton of Austrian conductor Joseph Griebel, on the most important Christian holidays-Easter and Pentecost-in 1844. ${ }^{7}$ Josif Rajačić, the Metropolitan of the Serbian Orthodox Church, celebrated these liturgies, with Greek and Russian priests as concelebrants. These festive liturgies in the Orthodox

\footnotetext{
2 The preliminary plan on conducting a broader, interdisciplinary examination of the connections of Kornelije Stanković with influential political figures that defended Serbian interests in AustriaHungary could not be realized due to reasonable causes. The data collected will be presented and systematized in a separate study.

3 Aleksandar Šmeman, Istorijski put pravoslavlja [The Historical Path of Eastern Orthodoxy] (Cetinje: Mitropolija Cetinjska-Atos, 1994).

4 On the enlightening motives of the Greek proponents of four-part singing and the inferiority complex of Balkan Greeks and Serbs regarding the unknown and alluring Austrian high art, particularly music traditions, see P. E. Formozes, Oi horodiakes ekdoseis tes ekklesiastikes mousikes se europaike mousike grafe stis duo orthodoxes elleneikes ekklesies tes Viennes [Editions of Choral Church Music in the European Music Notation in Two Greek Orthodox Churches in Vienna] (Thessaloniki: B. Regoupoulos, 1967); Giannes Filopoulos, Eisagoge stin ellenike polyphonike ekklesiastike mousike [Introduction to Greek Polyphonic Church Music] (Athens: Nefele Mousike, 1990); Peno, Pravoslavno pojanje na Balkanu, 63-67, 195-201.

5 The Greek authors of four-part scores presented manifestos on new musical trends in the prefaces of their publications. See Peno, Pravoslavno pojanje na Balkanu, 64-65.

6 The Greek text is romanized in the printed scores.

7 See P. E. Formozes, Oi horodiakes ekdoseis.
} 
temples were seen by the Vienna press in German, Greek and Serbian as cultural events par excellence, but also as ecclesiastical and political events of ecumenical importance. An additional reason for this was that, along with the "leading music figures of imperial court in terms of music," almost all dignitaries of Vienna's social milieu-representatives of different nations and confessions-also took part in the celebrations. ${ }^{8}$

The spiritual delight that the Orthodox and Roman Catholics of Viennaotherwise harshly divided by core national interests-shared on the occasion, was interpreted on the other side of the Balkans (considered in the broad sense), in Constantinople, as a betrayal of traditional values. An official epistle written in response and signed by members of the Greek Church Synod, headed by Ecumenical Patriarch Anthimus VI, was addressed in firstly to the Greek parishes in Vienna and Trieste, ${ }^{9}$ but also to all other local churches of the Orthodox world. ${ }^{10}$ The very epistle did not explicitly mention Slavic nations or the three centuries-long Russian tradition of polyphonic chant (and part songs). However, while Russians and their authentic music practice may have been neglected in Constantinople by chance, the Fener bishops did have in mind, along with their fellow Greeks, also Serbs, toward whom they had been exhibiting non-canonical ecclesiastical pretensions for an entire century. ${ }^{11}$

Rajačićs reply to the prelate of Constantinople concerning the "music novelties" in Vienna arrived with a two-year delay, after the so-called May Assembly of 1848 , on the occasion of which Rajačić was pronounced Patriarch. ${ }^{12}$ Not forgetting

8 See "Beč. Na Voskresenije [Vienna. On Easter]," Peštansko-budimski skoroteča 27 (1844): 159; M. Th., "O muzikalnom izobraženiju [On musical education]," Serbskij narodnij list 26 (1846): 202-206.

9 Greeks introduced harmony singing in Trieste in the same period.

${ }^{10}$ Engkuklios Patriarchike kai Sunodike Epistole katargousa kai apagoreusa ten kainotomon eisaxin kai chresin tes kainofanous tetrafonou mousikes en tes ierais akolouthiais ton apantachou orthodoxon ekklesion [Epistle of the Patriarchate and Synod condemning and proscribing the introduction and use of four-part music in the services of Orthodox churches] (Constantinople: Patriarchikes tou Genous Tupografio, 1846).

11 The Patriarchate of Constantinople non-canonically abolished the Patriarchate of Peć in 1776, threatening the autocephaly of the Serbian church. Although after the great migrations, Serbs north of the Sava and Danube were outside the sphere of influence of Constantinople territorially and in terms of ecclesiastical jurisdiction, pretensions from Fener extended beyond established boundaries. Patriarch Anthimus is known for his unjust approach to Slavic peoples in general, as well as despotic moves toward the Patriarchate of Alexandria.

12 On the same occasion, the Metropolitanate of Karlovci was, also nominally, raised to the level of Patriarchate. It has to be considered that these were only titular markers that were recognized by the Austrian emperor for political reasons, and were not the result of ecclesiastical law common to all official Orthodox churches. The canonical features of the Serbian Patriarchate were not recognized by other Orthodox churches, and the act of promulgation was interpreted particularly negatively in Constantinople. In correspondences with representatives of other Orthodox churches, Rajačić 
to point out that he himself was the Serbian archpriest and at the same time the archpriest of all Orthodox Christians in the Habsburg Empire, Rajačić did not miss the opportunity to acidly remind his Greek fellows of what he considered to be historical facts. He said that the Greek monophonic chant, referred to as "ancient and traditional" in the epistle, had little in common with the chant that Slavs, seeking "true faith," once heard in the Church of Hagia Sophia and made them so elevated that they "received Christianity from the Greeks." ${ }^{13}$ Rajačić was referring here to the emissaries of Russian Prince Vladimir in the late $10^{\text {th }}$ century, who were so impressed by the chanted church services in Constantinople that they revealed to their ruler how God was with the Romaioi, the people who praised him more beautifully than the Khazars, Mohammedans or Latins. ${ }^{14}$

Some might say this remark in the entirely cynical latter was not deliberate. Nevertheless, this vague reference to the Slavic, that is, Russian brethren who, attracted by chanting, joined the eastern Christian family, had a specific purpose. The Serbian political and church leader's affiliation with the Russian Ministry of Foreign Affairs and the Russian Church Synod was at the time particularly strong. ${ }^{15}$ Attempting to strengthen the shaken Serbian position in the Habsburg monarchy and restore church life, while also trying to stay above the proactive movements of Serbian middle-class youth in a non-coreligionist empire, Rajačić enjoyed strong support of Mikhail Fyodorovich Raevsky (1811-1884), who had been serving at the Russian Consulate in Vienna since 1842. The entire Russian diplomatic mission to help the Serbs on both sides of the Danube, but also across the Drina, all the way to Dalmatia and Montenegro, was organized by the Russian protopresbyter. His huge experience as a priest, ${ }^{16}$ and his multiple Pro-Slav engagements made him the head of Russian Church and a political hub for the Habsburg monarchy and the Balkans. ${ }^{17}$ Namely, Raevsky maintained relations with all leading Slavic

continued to be addressed as Metropolitan, and this was typical until the 1919 unification of the Serbian Patriarchate.

${ }^{13}$ Josif Rajačić, Svjatjejšemu vostočnija pravoslavnija Cerkvi Patriarhu Konstantinopolskomu Antimu v Požunje [To the Holy Patriarch of the Eastern Orthodox Church in Constantinople], Archive of the Serbian Academy of Sciences and Arts in Sremski Karlovci, MP-A 293-1848.

${ }^{14}$ Lavrentyevski letopis f. 37r, see http://litopys.org.ua/lavrlet/lavr05.htm\#lyst37.

${ }^{15}$ After the suffering of Serbs in war conflicts with Hungarians in 1848-1849, the ties with the Russian court and the Synod of the Russian Church strengthened even further.

${ }^{16}$ Before coming to Vienna, Raevsky served as a diplomat in Stockholm. See Nikola Petrović, "Dvadeset pisama Kornelija Stankovića Mihailu F. Rajevskom [Twenty letters from Kornelije Stanković to Mikhail F. Raevsky]," in Kornelije Stanković i njegovo doba, edited by Dimitrije Stefanović (Belgrade: Muzikološki institut SANU, 1985), 74.

17 The impressive list of Raevsky's correspondents that bears evidence to his abundant diplomatic activities includes the Russian consuls from Mostar, Rijeka (L. Berezin), Dubrovnik, Belgrade, Ioannina and Constantinople, Russian priests in various European capitals, and above all, the leading political figures and representatives of the Russian aristocracy, part of who were interested 
representatives in the Habsburg capital as well as elsewhere in the Empire, in the Principality of Serbia and in the Ottoman Empire who focused on the affirmation of national programs that concerned both the state and church. Not surprisingly, the Russian mission did not only go one way, merely fulfilling the expectations of fellow Slavs. Raevsky acted primarily on the foreign policy interests of his state and his Church when conducting specific activities directed toward cultural, educational and political emancipation of Serbs, Croats, Slovenes, Czechs and Bulgarians. ${ }^{18}$

A segment of his personal sphere of interest, as well as of his like-minded compatriots, was music. ${ }^{19}$ Common church chants, along with the common Old Church Slavonic language, could have additionally strengthened existing bonds between Russians and Serbs. More open Greeks in Vienna were also not indifferent to the specific, "Russian" church music style, of which the authors of prefaces and arrangers of the four-part liturgies by Randhartinger and von Preyer did not directly speak, but Josif Rajačić mentioned openly in his epistle to the Patriarch of Constantinople. In his reply to Fener regarding the events in 1844, he pointed out that not only did choral music not diminish, but on the contrary, it fostered unity at church services between Greeks, Serbs and Russians who found themselves in joint prayers in Vienna. The highest Orthodox Church official in the Austrian capital had a reason to feel diplomatically superior to the Patriarch of Constantinople, at least when it comes to the institutionalization of music reform in Orthodox temples in Austria. With such a feeling, he allowed himself to remind the first among the bishops of Constantinople ${ }^{20}$ of the far more complex problems among Christians in the Balkans that needed to be tackled before chant issues. ${ }^{21}$

in the "Serbian question," such as Count Dmitry Nikolaevich Bludov (1785-1864), a diplomat, president of the State Council of the Russian Empire and a great patron of the arts, and his daughter, countess Antonina Bludova (1813-1891), a writer and a close friend of Empress Maria Alexandrovna. See V. Matula, I. V. Čurkina, Zarubežnie Slavjane i Rossi, Dokumenti Arhiva M. F. Raevskoga 40-80-godi 19. veka [Slavs and Russians Abroad, Documents from the Archive of M. F. Raevsky 1840s-1880s] (Moscow: Nauka, 1975), 46-59.

18 Particularly during the period of forced Germanization of non-Austrian inhabitants of the empire, Raevsky played a great role in the spreading of Russian language among Slavs, using his wide network of contacts. His actions included publishing Russian textbooks, and historical reviews and reports on the political and cultural circumstances on the Balkans, which is confirmed in his prolific correspondence with the first person of the Moscow synodal publishing house, P. Bezonov, as well as the longstanding consul in the Bosnian Pashaluk, Slavicist Alexander Hilferding, and numerous Slavic cultural and political activists. Ibid., 35, 123-138.

${ }^{19}$ Balakyrev wrote to Raevsky several times from Prague on the importance of Russian art music among Czechs. Ibid., 27-29.

${ }^{20}$ In that time, the bishops of Constantinople were still responsible for the Serbs of Bosnia and Herzegovina and Old Serbia.

${ }^{21}$ Rajačić openly pointed to the Hellenic propensity for power, hypocrisy and corruption in his addresses to Patriarch Anthimus VI. Raevsky regularly received reports from Russian consuls on Greek bishops' unfortunate treatment of Serbs, particularly from Bosnia and Herzegovina, which 
In circumstances where each and every capacity needs to be recognized and utilized in efforts for national enlightenment and development, but also striving for Pan-Slavic unity, liberation from non-coreligionist government and non-canonical primacy of Constantinople in the not-yet-freed Serbian regions, the emergence of a talented young musician like Kornelije Stanković—his patron was Pavle Riđički (1805-1893), a well-respected landowner, industrialist and nobleman, a member of Matica srpska (since 1837) and author of the Constitution of the short-lived Serbian Vojvodina (1849) - could not have gone unnoticed. At Riđički's home, Stanković had the opportunity to meet, even before going to Vienna, the most prominent social and cultural activists among Serbs in Pest who were holding key positions in national and church assemblies and were directly involved with Patriarch Rajačić, as well as with leaders in the Principality of Serbia, officials of the Vienna court and Russian bearers of the idea of a Pan-Slavic revival. ${ }^{22}$ In a circle of true friends and like-minded university colleagues-closest to Stanković were philologist Jovan Bošković, painter Stevan Todorović, historian Fedor Demelić and Mihail Polit Desančić, a publicist, lawyer and politician-this young musician joined the all-national revival and Pan-Slavic mission with romantic zeal.

Judging by the letters he exchanged with Raevsky, Stanković started putting church and folk tunes on paper precisely on the initiative of his Russian patron. ${ }^{23}$ It is from him that he learned about the endeavors of Alexei Fyodorovich Lvov (1790-1870), a Russian violinist, composer and conductor who as the head of the Sankt Petersburg Court Chapel published a four-part harmonization of a well-known chant in 1839. No less, if not more, important was Patriarch Rajačićs encouragement for Stanković, since this young artist was the Patriarch's advantage the Greeks did not have: a man of their own kin and creed, educated on European

included forbidding to use their mother tongue in prayers. He then shared the information with the Russian Synod and Court, in which the Orthodox peoples outside their own homeland put their hopes of liberation.

22 We refer to the doctor of philosophy, writer and editor of the journal Letopis Matice srpske (1842-1847; 1850-1853), Jovan Subotić. In 1848, he initiated the formulating of Serbian requests before the "assembly" of Serbs in Pest. He was also a representative of Serbs in Pest on the May Assembly in Sremski Karlovci, where he was elected member of the Constitutional Board. Apart from Subotić, Riđički was also close friends with Konstantin Bogdanović (1811-1854), a lawyer, secretary of the State Council and member of the Society of Serbian Intellectuals in the Principality of Serbia. He was the personal secretary of Rajačić, maybe even in the year when the letter on choral music was sent to Constantinople. In the circle around Riđički, Kornelije Stanković also had the chance to meet Đorđe Stojaković (1811-1863), a lawyer from Pest, member of the Constitutional Board of the Serbian Vojvodina, a political advisor of Prince Miloš and Prince Mihailo Obrenović, and since 1856 a counselor of Vienna's highest court.

${ }^{23}$ Vesna Peno, “Jednoglasni zapisi crkvenog pojanja Kornelija Stankovića [Kornelije Stankovićs monophonic transcriptions of church chants]," in Tradicija kao inspiracija, edited by Sonja Marinković, Sanda Dodik (Banja Luka: Akademija nauka i umjetnosti Republike Srpske, Muzikološko društvo Republike Srpske, 2015), 199-211. 
premises, who was capable of putting chants previously fostered only through oral tradition into European notation and four-part choir sheets. Their attentive and strict evaluation of Stankovićs first works and insistence on close scrutiny of his scores prior to public performance spoke volumes of the fact that it was vital for both Rajačić and Raevsky that Stanković's work reflect traditional singing. ${ }^{24}$

With the support of influential figures, and confident that it was his task to bring to public attention unknown treasures of Serbian folk music, Stanković succeeded in becoming an acclaimed national music leader ${ }^{25}$ in the course of his short life. His numerous concerts attracted large audiences and were praised in the press on both sides of the Danube and Drina. Eventually, renowned Russian contemporaries became interested in Stanković's work, such was the aforementioned Lvov, or following the composer's death also Vladimir Fyodorovich Odoyevsky, a Russian prince, the founder of the Russian Music Society and the Conservatorium in Moscow, as well as a close associate of Dmitry Razumovsky, a reputable Russian mediaevalist and ancient Russian chant scholar.

That Stanković was recognized as a Serbian music missionary among his contemporaries due to his multi-layered and diversely directed Russian-Serbian and Pan-Slavic diplomatic activities was confirmed with his nomination for the Order of St. Stanislaus, $3^{\text {rd }}$ class. For this award he was endorsed by protopresbyter Raevsky on September 8, 1862, on the occasion of the celebration of 1000 years

\footnotetext{
24 See Appendix, Figure 6. Both Stankovićs liturgies were performed with the patriarch's blessing during services he celebrated. The first four-part Liturgy was sung by a mixed choir on the second day of Easter in Patriarch Rajačićs home chapel. See Đorđe Perić, "Bibliografija Kornelija Stankovića [The bibliography of Kornelije Stanković]," in Kornelije Stanković i njegovo doba, 289. In a letter to Pavle Riđički from April 27, 1851, the composer states that the Liturgy was performed in the Greek church on Easter the same year in the presence of the patriarch and a great crowd of believers: "Greeks, Russians, Serbs and Germans, including composer Simon Sechter." Although without directly saying so, Stanković reveals that his Liturgy was presented by mentioning that "Christ Is Risen sounded for the first time." See Ivanka Veselinov, "Iz prepiske Kornelija Stankovića [From Kornelije Stanković's correspondence]," in Kornelije Stanković i njegovo doba, 87. In a letter from May 11, 1858, Karlovci Archpriest Atanasije Popović, whom the patriarch charged with monitoring Stanković's work, reported to Rajačić that at the Pentecost celebration in the Russian church in Vienna the vespers were served "with our chants, to the pleasure and joy of the numerous Orthodox believers." See Archive of the Serbian Academy of Sciences and Arts in Sremski Karlovci, ASANUSK MP-A 517-1858, according to Dimitrije Stefanović, "Prilog proučavanju notnih autografa, arhivskih i drugih dokumenata o Korneliju Stankoviću [A contribution to the study of musical autographs, archival and other documents about Kornelije Stanković]," in Kornelije Stanković i njegovo doba, 124). On Serbian the chants collected in Karlovci and Stanković's choir arrangements performed on Easter and Pentecost in the Russian chapel in Vienna, the journal Srbski dnevnik (Serbian daily) reported in 1858. See Milana Bikicki, "Kornelije Stanković u vojvodjanskoj štampi [Kornelije Stanković in the press of Vojvodina]," in Kornelije Stanković i njegovo doba, 212.

${ }^{25}$ Stanković's works were, along with advertisements in the Serbian press, subject to valuable subscriptions.
} 
of Russian statehood in Novgorod. ${ }^{26}$ This award from the Russian side was an additional motive for Belgrade Metropolitan Mihailo Jovanović, who studied in Russia and was closely associated with Raevsky, to put in a good word for the young artist in the Principality of Serbia. ${ }^{27}$

The fact that diplomatic dispatches with information on the activities of influential Austrian citizens of Serbian origin circulated quite well between Belgrade and Vienna—not only between Vienna and Sankt Petersburg — and were tightly linked to Russian diplomatic activities may be confirmed by one report of the Austrian consul in Belgrade. He sent a note to the Ministry of Foreign Affairs in Vienna proposing that Stanković be awarded the Knight's Cross of the Imperial Austrian Order of Franz Joseph. It is curious that this proposal came a year before the Serbian musician was decorated by the Russians. ${ }^{28}$ In a conspicuous excerpt from the dispatch, the consul described that an imperial subject, Kornelije Stanković, was the only person among Serbs who dedicated himself professionally to music, choosing it as his life purpose. For a nation like Serbs, in which noble arts and crafts were so underdeveloped, this was such an odd and curious occurrence that he humbly dared not go in further detail or even think of providing more information to his Imperial Highness ${ }^{29}$. Drawing attention to Stankovićs close relationship with Riđički, who had recently been awarded with the highest grace by his Imperial Highness, as well as his successful studies with Sechter, which attracted attention of Patriarch Rajačić, the Austrian consul emphasized that it was this church dignitary who assigned Stanković the "arduous task of collecting and arranging Serbian (Eastern Orthodox) chants living only in oral tradition into four-voice scores by following strict scholarly rules." ${ }^{30}$ Having confirmed that the Serbian musician was

\footnotetext{
${ }^{26}$ On the same occasion, Metropolitan Mihailo Jovanović (1826-1898) was awarded the Order of St. Anna, $1^{\text {st }}$ class, while Vuk Karadžić, Jovan Subotić and Jovan Hadžić were given the Order of St. Anna, $2^{\text {nd }}$ class.

${ }^{27}$ Metropolitan Jovanović was one of Stankovićs many patrons. An ardent supporter of PanSlavism, who led the Serbian Church in accordance with the diplomatic directions of the Russian state and Church of the late $19^{\text {th }}$ century, he admired Russian church music as well as Stankovićs musical undertakings. He advocated for prince Mihailo Obrenović to open a department for multi-part church singing in Belgrade. He also financially supported the publishing of Stankovićs Liturgy, which was printed in Vienna in 1862. (Mirka Pavlović, "Zaostavština Kornelija Stankovića [Kornelije Stanković's manuscripts]," in Kornelije Stanković i njegovo doba, 166; Dimitrije Stefanović, "Mitropolit Mihailo i Kornelije Stanković [Metropolitan Mihailo and Kornelije Stanković]," in Život i delo mitropolita Mihaila (1826-1898), edited by Dimitrije Stefanović (Belgrade: SANU, 1994), 299-300. About the cooperation between Stanković and Metropolitan Mihailo Jovanović, see also Peno, Pravoslavno pojanje na Balkanu, 118.

28 The report with the mentioned proposal was written on June 19, 1861.

${ }^{29}$ V., "Izveštaj," Muzički glasnik 9 (1922): 5-6.

${ }^{30} \mathrm{Ibid}$. The consul also referred to Stankovićs fundraising performance for the construction of a Serbian church in Vienna in 1862, which was well received by Viennese art critics, and announced his journeys across Serbia, Croatia and Dalmatia with an aim of collecting folk songs.
} 
a politically and morally upstanding imperial subject, the consul also presented the actual political motives behind his proposal: "in this politically convenient moment, an opportunity has arisen to award not only Stanković for his merits in music, but the entire Serbian community in Austria. The main task given to this very talented young man, to collect, put into four-part choir scores and publish all liturgies of the Eastern Orthodox Church, is a chance which, bearing in mind the well-known character of Orthodox Christians, will not pass without particular interest of priests and the common people as well [...]. It seems politically significant that such a task is carried out by an Austrian subject with German education, because his work, unique as it is, cannot be limited to the area of the Patriarch of Karlovci, but will influence all Slavic Orthodox churches." ${ }^{11}$ In the final part of his dispatch, the Austrian diplomat fully revealed the reasons why the Serbian musician should be decorated, stating that such an act of political thoughtfulness, to indulge Austrian Serbs with rights regarding their faith in every possible way, was aimed at turning away their priests from Russia, whose propaganda in religious and political issues, conducted in a fickle manner, had to be reduced in significance and essence as Austrian Serbs gained more national and ecclesiastical independence. ${ }^{32}$

What happened after the dispatch is well known: Stanković did not receive the Knight's Cross of the Order of Franz Joseph, nor did he manage to visit Russia due to his advanced illness, despite his fervent wish to get to know the Russian chant from its very source, and to present his work to Russians himself. His musical diplomatic mission among South Slavs, particularly Croats, lasted as long as he was popular and famous, as long as they saw any use in him. Nevertheless, his work and legacy gained wide acclaim ${ }^{33}$ already by the end of the $19^{\text {th }}$ century when liturgical music of the Serbian Church and on concert stages was canonized by the work of another socially very prominent musician, Stevan Stojanović Mokranjac. ${ }^{34}$ But regardless of how much the work of the first learned Serbian musician was overshadowed by the socially, diplomatically and musically superior Mokranjac, ${ }^{35}$ it is undeniable that Stanković, under the influence of his patrons, initiated the shift in Serbian church music from Eastern monophony toward Western polyphony. Russian

\footnotetext{
31 It is obvious that the Austrian consul was convinced in what Stanković believed-that his harmonizations of "the most beautiful Serbian melodies of all of Orthodoxy will be heard in the churches of other Christian peoples." See Fedor Demelić, "Kornelije Stanković," Letopis Matice srpske 39/110 (1867): 210 (188-234).

32 V., "Izveštaj," 6.

${ }^{33}$ See Pavlović, "Zaostavština Kornelija Stankovića."

${ }^{34}$ Vesna Peno, Ivana Vesić, "From Myth to Reality: Stevan Stojanović Mokranjac and Serbian Church Music," Musicological Annual 54/1 (2018): 49-58.

${ }^{35}$ See Biljana Milanović (Ed.), Stevan Stojanović Mokranjac (1856-19014). The Belgrade Choral Society Foreign Concert Tours (Belgrade: Institute of Musicology SASA, Serbian Musicological Society, 2014).
} 
church music had already taken this course three centuries earlier, which is why the emergence of harmonization of the one-voice/one-part chant, which has been considered "Serbian" ever since, was easily marked and accepted as traditional. 36 There is no doubt that emergence of choral "Serbian folk" church music was one of the outcomes of the general political and cultural tendencies, in which one can follow reliable traces of diplomatic activities. These aspects accentuate the position uttered at the beginning of this paper about revising the pages written in Serbian music historiography on musicians whose more or less transparent diplomatic engagement left a mark on Serbian church music.

\footnotetext{
${ }^{36}$ In the preface to his Liturgy, Stanković wrote a sort of national music manifesto, explaining his reasons for using a multi-part choral arrangement in which he incorporated folk tunes. See Kornelije Stanković, Pravoslavno crkveno pojanje u srbskog naroda I [Orthodox Chant of the Serbian People I] (Vienna, 1862; phototype edition, edited by Danica Petrović, Belgrade-Novi Sad: SANU, Narodna biblioteka Srbije, Matica srpska, 1994).
} 


\section{References:}

“Beč. Na Voskresenije." Peštansko-budimski skoroteča 27 (1844): 159. [Orig. in Serbian Cyrillic]

Bikicki, Milana. "Kornelije Stanković u vojvodjanskoj štampi.” In Kornelije Stanković $i$ njegovo doba, edited by Dimitrije Stefanović, 205-225, Belgrade: Muzikološki institut SANU, 1985. [Orig. in Serbian Cyrillic]

Demelić, Fedor. "Kornelije Stanković." Letopis Matice srpske 39/110 (1867): 188-234. [Orig. in Serbian Cyrillic]

Engkuklios Patriarchike kai Sunodike Epistole katargousa kai apagoreusa ten kainotomon eisaxin kai chresin tes kainofanous tetrafonou mousikes en tes ierais akolouthiais ton apantachou orthodoxon ekklesion. Constantinople: Patriarchikes tou Genous Tupografio, 1846.

Filopoulos, Giannes. Eisagoge stin ellenike polyphonike ekklesiastike mousike. Athens: Nefele Mousike, 1990.

Formozes, P. E. Oi horodiakes ekdoseis tes ekklesiastikes mousikes se europaike mousike grafe stis duo orthodoxes elleneikes ekklesies tes Viennes. Thessaloniki: B. Regoupoulos, 1967.

Lavrentyevski letopis f. 37r, http://litopys. org.ua/lavrlet/lavr05.htm\#lyst37.

M. Th. “O muzikalnom izobraženiju.” Serbskij narodnij list 26 (1846): 202-206. [Orig. in Serbian Cyrillic]

Matula, V., Čurkina, I. V. Zarubežnie Slavjane i Rossi, Dokumenti Arhiva M. F. Raevskoga 40-80-godi 19. veka. Moscow: Nauka, 1975. [Orig. in Russian Cyrillic]

Milanović, Biljana (Ed.). Stevan Stojanović Mokranjac (1856-19014). The Belgrade Choral Society Foreign Concert Tours. Belgrade: Institute of Musicology SASA, Serbian Musicological Society, 2014.
Pavlović, Mirka. "Zaostavština Kornelija Stankovića." In Kornelije Stanković i njegovo doba, edited by Dimitrije Stefanović, 123-135, Belgrade: Muzikološki institut SANU, 1985. [Orig. in Serbian Cyrillic]

Peno, Vesna. "O višeglasju u bogoslužbenoj praksi pravoslavnih Grka i Srba: teološkokulturoloski diskurs.” Muzikologija 17 (2014): 129-154. [Orig. in Serbian Cyrillic]

Peno, Vesna. "Jednoglasni zapisi crkvenog pojanja Kornelija Stankovića." In Tradicija kao inspiracija, edited by Sonja Marinković, Sanda Dodik, 199-211. Banja Luka: Akademija nauka i umjetnosti Republike Srpske, Muzikološko društvo Republike Srpske, 2015. [Orig. in Serbian Cyrillic]

Peno, Vesna. Pravoslavno pojanje na Balkanu na primeru grčke i srpske tradicije: između Istoka i Zapada, eklisiologije $i$ ideologije. Belgrade: Muzikološki institut SANU, 2016. [Orig. in Serbian Cyrillic]

Peno, Vesna, Vesić, Ivana. "From Myth to Reality: Stevan Stojanović Mokranjac and Serbian Church Music." Musicological Annual 54/1 (2018): 49-58.

Perić, Đorđe. "Bibliografija Kornelija Stankovića.” In Kornelije Stanković i njegovo doba, edited by Dimitrije Stefanović, 287-326. Belgrade: Muzikološki institut SANU, 1985. [Orig. in Serbian Cyrillic]

Petrović, Nikola. "Dvadeset pisama Kornelija Stankovića Mihailu F. Rajevskom.” In Kornelije Stanković i njegovo doba, edited by Dimitrije Stefanović, 73-83. Beograd: Muzikološki institut SANU, 1985. [Orig. in Serbian Cyrillic] 
Rajačić, Josif. Svjatjejšemu vostočnija pravoslavnija Cerkvi Patriarhu Konstantinopolskomu Antimu v Požunje, ASANUSK, MP-A 293-1848. [Orig. in Serbian Cyrillic]

Stanković, Kornelije. Pravoslavno crkveno pojanje u srbskog naroda I, Vienna, 1862. phototype edition, edited by Danica Petrović, Belgrade-Novi Sad: SANU, Narodna biblioteka Srbije, Matica srpska, 1994. [Orig. in Serbian Cyrillic]

Stefanović, Dimitrije. "Prilog proučavanju notnih autografa, arhivskih i drugih dokumenata o Korneliju Stankoviću." In Kornelije Stanković i njegovo doba, edited by Dimitrije Stefanović, 123-135. Belgrade: Muzikološki institut SANU, 1985. [Orig. in Serbian Cyrillic]
Stefanović, Dimitrije. "Mitropolit Mihailo i Kornelije Stanković." In Život i delo mitropolita Mihaila (1826-1898), edited by Dimitrije Stefanović, 293-304. Belgrade: SANU, 1994. [Orig. in Serbian Cyrillic]

V., "Izveštaj." Muzički glasnik 9 (1922): 5-6. [Orig. in Serbian Cyrillic]

Veselinov, Ivanka. "Iz prepiske Kornelija Stankovića." In Kornelije Stanković i njegovo doba, edited by Dimitrije Stefanović, 85-102. Belgrade: Muzikološki institut SANU, 1985. [Orig. in Serbian Cyrillic]

Šmeman, Aleksandar. Istorijski put pravoslavlja. Cetinje: Mitropolija Cetinjska, Atos, 1994. [Orig. in Serbian Cyrillic] 


\section{APPENDIX}

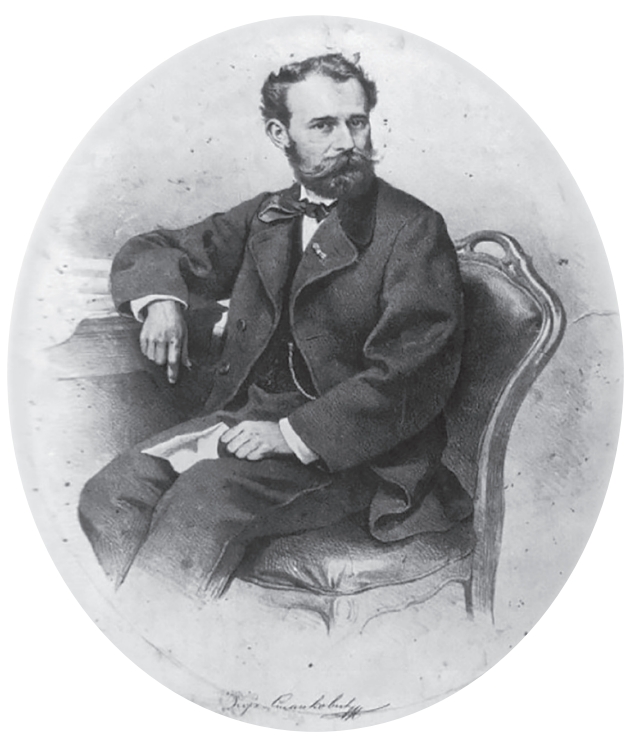

Figure 1.

Kornelije Stanković (1831-1865),

https://www.medias.rs/kornelije-stankovic-kompozitor-pijanista-i-horovodja.

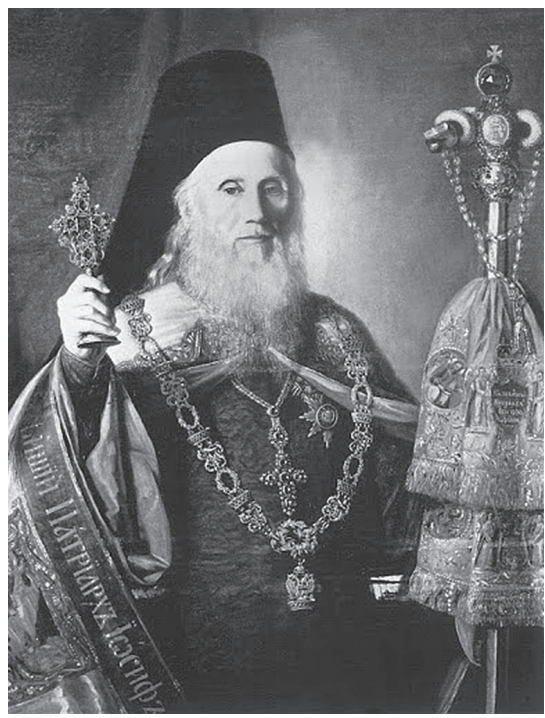

Figure 2.

Josif Rajačić, the Metropolitan of Karlovci and Serbian Patriarch (1785-1861), www.riznicasrpska.net.

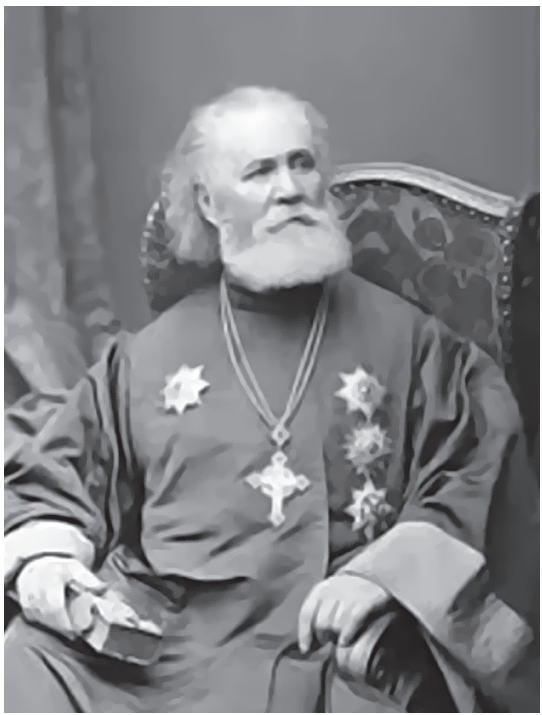

Figure 3.

Mikhail Fyodorovich Raevsky, archpriest (1811-1884), stated in Wikimedia. 
xopós No. KK. 'O Xtpovizsis 'T'upos.

iz- Andrate.

(2)

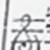

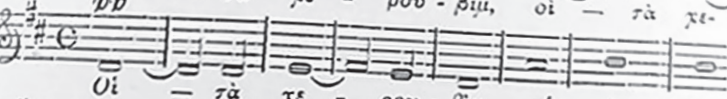

(2)

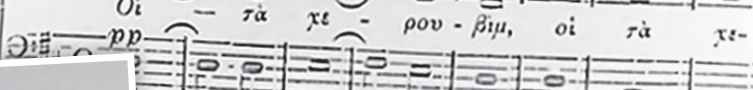

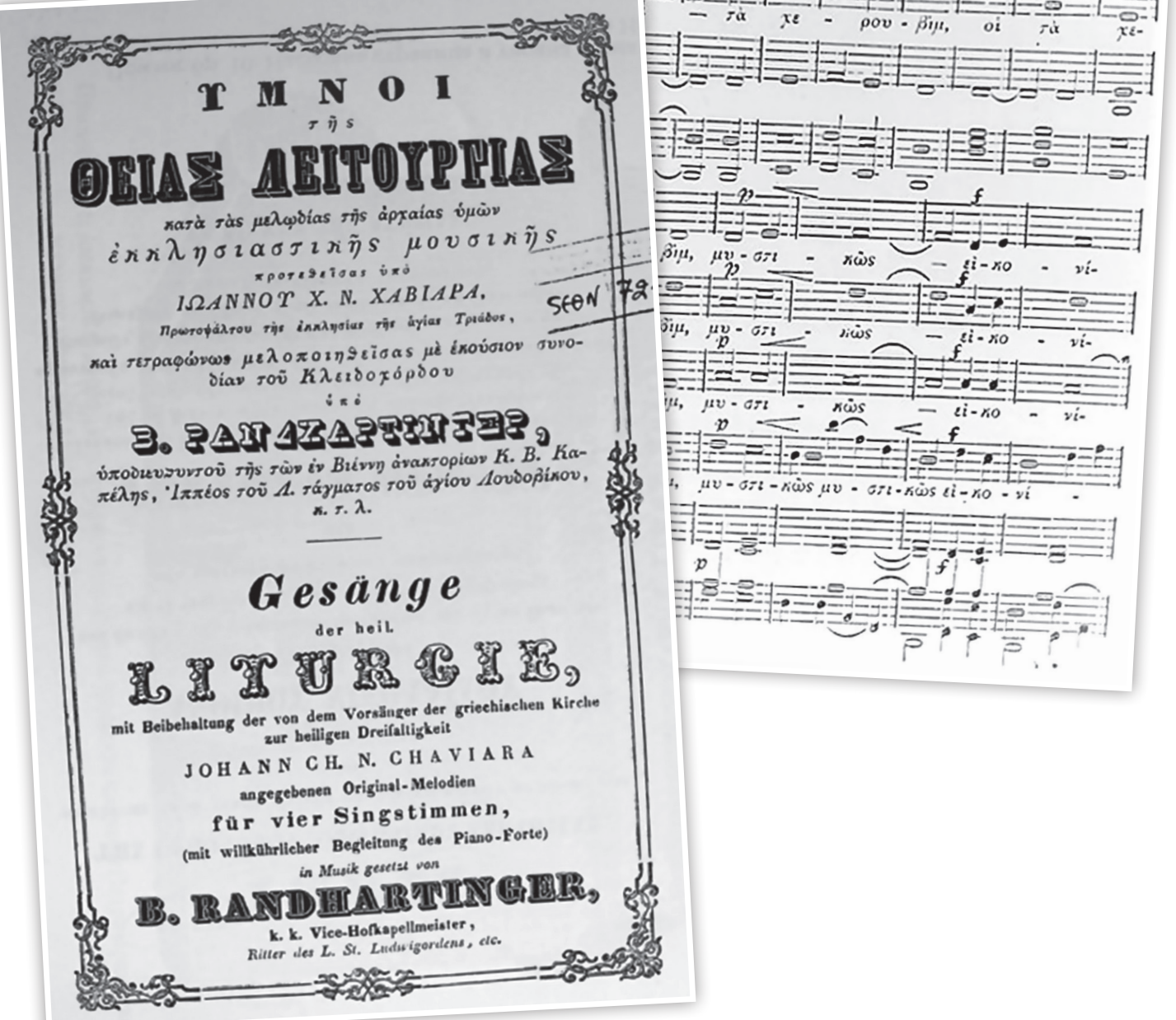

Figure 4 .

Cover page and excerpt from the score of Benedict Randhartinger's Liturgy. 


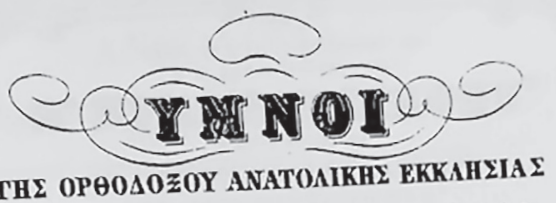

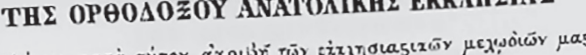

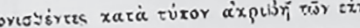
$\dot{0} \geq 0^{\circ}$

\section{AVOIMOY NIKOAAIIAOY}

Teropespizos,

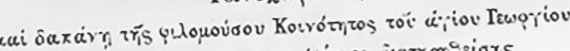



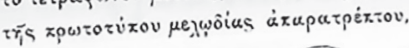

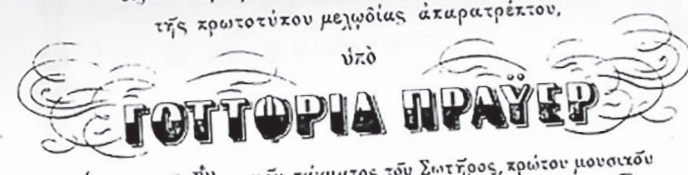

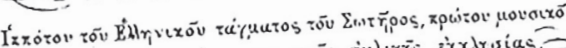



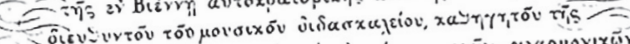

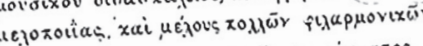
Eт

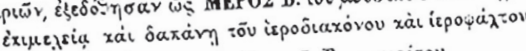

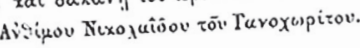

È BIÉNNH TḦ̌ AYYsPIAE

1847.

Figure 5.

Cover page and excerpt from the score of Gottfried von Preyer's Liturgy. 


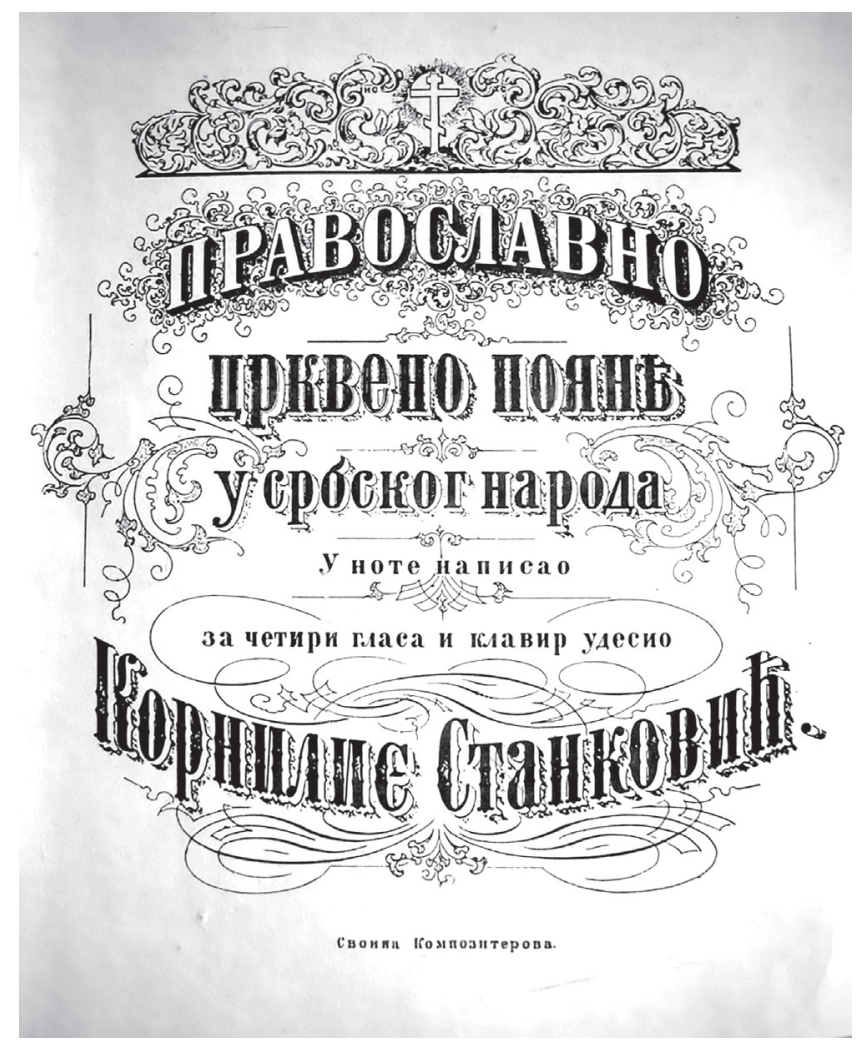

Figure 6.

Cover page of Kornelije Stanković's

Pravoslavno crkveno pojanje u srbskog naroda. 


\title{
Petar Bingulac, musicologist and music critic in the diplomatic service
}

\author{
Ratomir Milikić
}

Little can be found about Petar Bingulac (Vukovar, 1897 - Belgrade, 1990) in historiographic papers that do not refer to musical arts and musicology, where he left an indelible mark. As a historian exploring diplomatic history, while harboring deep respect and passion for classical music, the author of this paper did not dare until recently to even think about drawing a link between Petar Bingulac, the diplomat, and Petar Bingulac, the music theorist bravely traversing across national musical heritage, secular and religious alike. Unfortunately, not even to a genuine Renaissance man like Petar Bingulac has been granted a properly elucidated niche in professional literature he truly deserves. Encyclopedic references aside, there is not much to learn about his life in diplomacy outside archival records.

Some time ago, we researched the position of officers in a prisoner-of-war camp in Strasbourg in 1944. On the location of the officers' camp, a chapel with wall paintings dedicated to St. Sava survived, which the Republic of France protected as a heritage site. All the credit for the birth of this chapel goes to a group of imprisoned active-duty and reserve officers, patriots who never let their confinement get to them and obliterate their faith. ${ }^{1}$ Petar Bingulac ${ }^{2}$ was one of them. In a number of memoir testimonials by those who either remained émigrés after WWII or returned home and offered the completely new political and state setup a window into the horrific experience of camps, we can find a few notes about a choir in that particular camp. ${ }^{3}$ The choir raised

\footnotetext{
1 See Milutin Simić, Hram svetog Save u okolini Strazbura [St. Sava Temple near Strasbourg] (Belgrade: Čigoja štampa, 2000); Ratomir Milikić, "Nepokretno i pokretno kulturno nasleđe Srba u Francuskoj iz dva svetska rata: pomoć Francuske Srbiji kroz likovnu umetnost 1914-1916. godine i oficirski logor u Strazburu (1944) [The tangible and intangible cultural heritage of Serbs in France from the two World Wars: French support for Serbia through visual arts 1914-1916 and the officers' camp in Strasbourg (1944)]," in Očuvanje i zaštita kulturno-istorijskog nasleđa Srbije u inostranstvu, edited by Vidoje Golubović, Branislav Đorđević (Belgrade: Institut za međunarodnu politiku i privredu, 2017), 312-327.

2 Among the officers also held in the camps near Strasbourg were Professor Pavle Vasić, Stanislav Beložanski, Dragomir Arambašić, Colonel Branislav Pantić, as well as Milan Bartoš, Oto Bihalji Merin, Rafailo Blam, Đorđe Karaklajić, and many other active-duty and reserve officers.

3 See more in Stanislav Vinaver, Godine poniženja i slobode. Život u nemačkim oflazima [Years of Humiliation and Freedom. Life in German War Camps] (Belgrade: Prosveta, 1945); Branislav J. Pantić,
} 
morale and successfully instilled hope in prisoners, encouraging them not to lose their spirits. The choirmaster ${ }^{4}$ was Petar Bingulac. From Bingulac's diplomatic file, we can learn that he was granted the rank of reserve lieutenant colonel in 1926, which is why he spent the war in the officers' camp. ${ }^{5} \mathrm{Had}$ he remained home, he could have met a much worse fate, as was the case with several other career diplomats. ${ }^{6}$

It was not until we gained insight into his life in the camp that we came to the conclusion that Petar Bingulac, the camp choirmaster of Strasbourg, was the same Petar Bingulac whose name we had come across so often in diplomatic reports from the 1930s.

Unfortunately, literature on the work of the Ministry of Foreign Affairs of the Kingdom of Serbs, Croats and Slovenes (SCS) / Kingdom of Yugoslavia, is very scarce, ${ }^{7}$ while employees of this important department have been researched even less. This paper makes a modest contribution through a biographical note on Petar Bingulac, the diplomat.

Petar Bingulac was admitted to the Ministry of Foreign Affairs of the Kingdom of SCS in August 1925 as a 28-year-old lawyer. Employment-wise, the foreign ministry was as closed to the broader population as it is today, and it was

Banditsko-komunistički logor 1945 [The Bandit-Communist Camp 1945] (Sidney: s.n., 1964); Staja Stajić, Dva miliona minuta do slobode [Two Million Minutes to Freedom] (Belgrade: Prosveta, 1963), 172.

4 A little scroll was painted on the chapel wall, reading: "And Bingulac's choir sang the ekteniya."

5 Archives of Yugoslavia [Arhiv Jugoslavije (AJ)], Ministry of Foreign Affairs of the Kingdom of Yugoslavia [Ministarstvo spoljnih poslova Kraljevine Jugoslavije] (334), Personnel Section (box No. 139), Correspondence (No. 4491) by the City Council of Vukovar, dated June 24, 1927.

6 The lives and careers of diplomats of the Kingdom of Yugoslavia took very different directions. Some managed to stay outside Yugoslavia and serve the legitimate government-in-exile of the Kingdom of Yugoslavia, which earned international recognition and was seated in London/Cairo. Some were interned and sent back to their occupied home country (the largest group was led by Ivo Andrić, the Ambassador to Germany at the time), and a smaller group of diplomats were confined to prisoner-of-war camps for officers (including Petar Bingulac, who had been drafted as a reserve officer). The worst fate befell the diplomats exposed to repressive measures by the occupation authorities. Two brothers, Ilija and Aleksandar Milikić, along with former head of legation Aleksandar Bodi, were arrested and shot by the Gestapo over charges of espionage, while another former head of legation, the Consul General in Prague, Radovan Šumenković, was sent to a concentration camp, leaving behind a memoir he wrote after the war to testify to his dark days of incarceration. The Ministry of Foreign Affairs of the Kingdom of Yugoslavia was liquidated shortly after the 1941 occupation, and it is curious that there are no records of the liquidation anywhere in the archives of the Republic of Serbia.

7 The earliest monograph about the Ministry of Foreign Affairs of the Kingdom of Yugoslavia is Pavle Karović's Diplomacija [Diplomacy] (Belgrade: Geca Kon, 1937), and the most comprehensive one published recently is Srđan Mićićs study Od birokratije do diplomatije - Istorija jugoslovenske diplomatske službe 1918-1939 [From Bureaucracy to Diplomacy-The History of the Yugoslav Diplomatic Service 1918-1939] (Belgrade: Institut za noviju istoriju Srbije, 2018), but the latter makes no mention of Petar Bingulac. 
hardly possible to gain entry into the closed ranks without a personal intervention. ${ }^{8}$ For Petar Bingulac, it was his father's intervention. Nikola Bingulac was an MP for the People's Radical Party ${ }^{9}$ at the time, and it is a letter he wrote in 1925 on stationary with the National Assembly's header that testified to his vouching for his son. Truth be told, he was only asking that Petar be granted a month's leave so that he could defend his $\mathrm{PhD}$ at a law school in Paris, which indeed he was, and very quickly. He defended the thesis at the end of that same year. ${ }^{10}$

Petar Bingulac started his diplomatic career the same way as most of his peers-as an intern serving in different sectors. His first job was with the Department for the Enforcement of International Treaties, which was a very important one, analyzing and monitoring the implementation of international conventions, as well as the enforcement of those the Kingdom had acceded to. According to his first Qualification Report for 1925 (qualification reports were prepared for every civil servant at the time), his work was described as very good, as he was involved in legal affairs, and his conduct as appropriate and very decent. His superiors also noted the young intern's sense of initiative at work and his discretion. ${ }^{11}$ Bingulac made an equally favorable impression the following year, this time with a special emphasis on the quality of his translations of international treaties from German, Italian and English. ${ }^{12}$

He continued to work for the Department (with brief interruptions) until April 1928, when he was allowed to take the state licensing exam. Upon passing the exam (for which no records are preserved), he was appointed as a clerk at the same Department. In September 1928, he moved to the Code Section of the

\footnotetext{
8 Both at the time of the Kingdom of Serbia and after the Great War in the Kingdom of SCS/Yugoslavia, a veil of secrecy cloaked admissions to the Ministry of Foreign Affairs. An entrance exam was prescribed, and there was a level of knowledge usually expected from all candidates for internships, but those requirements were frequently derogated from. The Ministry's admissions program was complicated and very demanding, but a way around the obstacle could be found. As it happened, even members of examination committees would sometimes help candidates. Patronage dominated the institution to the extent that it often subdued competence, which was why it was pejoratively dubbed the "Yellow House." See more in Ratomir Milikić, "IIvo Andrić" o Žutoj kući ili jedan denuncijantski pamflet o Ministarstvu inostranih poslova Kraljevine Jugoslavije [Ivo Andrić on the Yellow house, or a pamphlet on the Ministry of Foreign Affairs of the Kingdom of Yugoslavia]," Istorija 20. veka I (2018): 57-68.

9 There was not much mention of his father in professional literature either. Nikola Bingulac's name was neither in the Kingdom's pioneer publishing endeavor Ko je ko u Jugoslaviji [Who is Who in Yugoslavia] (Belgrade; Jugoslovenski godišnjak, Zagreb, Nova Evropa, 1928), nor in the biographical lexicon of the time, Senat, Narodna skupstina [The Senate, the National Assembly], edited by Č. Mitrinović (Skopje: Nemanja, 1935).

10 AJ, 334-139, A letter dated November 7, 1925 to the Minister of Foreign Affairs by Nikola Bingulac, MP, using stationery with the letterhead of the People's Radical Party faction in the National Assembly.

11 AJ, 334-139, Qualification Report for 1925, dated January 18, 1926.

12 AJ, 334-139, Qualification Report for 1926, dated February 9, 1927.
} 
Political Department, receiving an excellent grade that same year. ${ }^{13}$ Owing to the inherent sensitivity, work with codes implied diligence and commitment, as well as confidence, which had to be earned. In Diplomacija, Pavle Karović wrote about the work in the Department: "[It is necessary] to entrust well-rewarded officers with work on codes, as this very important job is unusually tedious, yet it requires a conscientious and perseverant person and, quite often, plenty of overtime."

In April 1929, a problem arose in connection with Petar Bingulac's post. Even though the Ministry of Foreign Affairs was very well disposed, having signed with Bingulac a fulltime employment contract in June 1928, and awarded him with a salary a grade above the one prescribed by law, the State Council decided to abolish his employment class (civil servants were divided into "classes" then), and started a lawsuit that lasted for years until the statute of limitations on the case eventually expired to the benefit of Bingulac. ${ }^{14}$

The end of 1929 found him in the Kingdom's delegation to the Reparation Commission headquartered in Paris. The French capital hosted a session of the commission of experts overseeing the payment of war reparations for the damage caused by the Axis powers, led by Germany, from February 11 to June 7, 1929.

It was also Petar Bingulac's first truly diplomatic post. Although no records are available of his stay in Paris, ${ }^{15}$ the available sources put Bingulac in the Political Department of the Ministry of Foreign Affairs as early as late 1930, when he wrote a request to be allowed to marry Anđa Bunuševac, a law graduate and a journalist at the newspaper Politika. ${ }^{16}$ That request, too, was granted in record time. ${ }^{17}$ In that same period, on September 6, 1930, he was awarded the Order of the Yugoslav Crown (Rank V); it was the first version of the Order and one of the earliest awards of the honor that was only established earlier that year. ${ }^{18}$

\footnotetext{
13 Pavle Karović, Diplomacija, 71.

${ }^{14}$ AJ, 334-139, Correspondence between the Court of Auditors, the State Council and the Ministry of Foreign Affairs under Reference No. 60.852.

15 The Archives of Yugoslavia do not hold records of the Ministry of Foreign Affairs related to the work of the Yugoslav delegation at that important conference.

16 AJ, 334-139, A request to the Minister dated November 18, 1930, referring to Anđa Bunuševac as a law graduate, a Politika newspaper associate and daughter of Belgrade's industrialist Rista Bunuševac.

17 AJ, 334-139, The Minister's consent dated November 21, 1930, sent through the Administration Department, (confidential) No. 4027, dated November 22, 1930.

18 The Order of the Yugoslav Crown was the only honor established in the joint state between the two World Wars. In April 1930, shortly after the Kingdom was renamed Yugoslavia and a personal regime was set up, the first (and also only) honor that was linked solely to the tradition of the joint state was instituted. All preceding decorations only mirrored the tradition of the Kingdom of Serbia. The Order, modeled after the French Legion of Honor, was bestowed in "recognition of achievements made for the King and Homeland, the unity of the state and the peoples." The first version of the Order was made in a dozen copies (all ranks included) and ceased to exist in December that same year, 1930. After that, a version designed in a slightly different way was
} 
In January 1931, he was assigned as a clerk to the Consulate General in Hamburg, but after a few days the decision was reversed, and he was reassigned to the Consulate General in Milan in the same capacity. ${ }^{19} \mathrm{He}$ came through his first year of service with flying colors, and in addition to the excellent grade, he was described as "a highly intelligent mind, a broadly educated, extremely conscientious clerk with pleasant demeanor." ${ }^{20}$ His son, Nikola, was born in Milan on April 28, 1932. Bingulac was very successful in performing all consular duties, while following the Italian press and keeping the books at the same time. However fragmented and scattered they may be, the records of the Consulate General in Milan ${ }^{21}$ paint a portrait of a young diplomat in his first post abroad, with the scope and content of genuine diplomatic work. Bingulac was taking care of general affairs in a consular office that was very important for the Kingdom of Yugoslavia when Mussolini's regime was at the peak of his power and prestige. Aside from the consular affairs concerning Yugoslav citizens in Italy, Bingulac's responsibilities included those of today's press attachés, following the Italian media and monitoring the press coverage of the Kingdom of Yugoslavia.

For his successes, Bingulac's superior, Consul General Svetislav Predić, ${ }^{22}$ nominated him for a promotion. The young diplomat was promoted a year later, in 1933, when he became a vice-consul.

In January 1934, he was supposed to end his term in Italy and be appointed secretary at the foreign ministry. That appointment was also delayed, and Bingulac did not return to Belgrade until mid-1934, when he reported to the Political Department (Section V) of the Ministry of Foreign Affairs of the Kingdom of Yugoslavia. ${ }^{23}$ We feel that in a bid to learn more about the budding diplomat's other side, a list of things he brought from Milan might be thought-provoking

awarded. For more see Pavel Car, Tomislav Muhić, Odlikovanja Srbije i Jugoslavije od 1859. do 1941. [The Orders of Serbia and Yugoslavia from 1859 to 1941] (Vienna: Verlag Militaria, 2012), 340.

19 AJ, 334-139, Petar Bingulac's career postings until January 1931. Such last-minute changes to service arrangements abroad were very rare, but Bingulac's was not the only case. Even today, it is not very popular to make changes once a diplomatic post abroad has been set.

${ }^{20}$ AJ, 334-139, Qualification Report for 1931.

${ }^{21} \mathrm{AJ}$, Consulate General of the Kingdom of Yugoslavia in Milan [Generalni konzulat Kraljevine Jugoslavije u Milanu] (419).

22 Before he joined the diplomatic service, Svetislav Predić was vice-governor of the Prometna Banka trade bank in Belgrade, as well as the chair and chief counsel of the City of Belgrade. Predić was also the secretary of the Industrial Chamber and an inspector at the Ministry of Trade and Industry. For him, too, the post in Milan was the first diplomatic appointment, after a brief engagement at the Kingdom's Ministry of Foreign Affairs.

${ }^{23}$ Section V of the ministry's Political Department was in charge of drafting, publishing and applying international treaties and conventions. This department was "a true foreign policy maker, where all the information, inputs and notifications on the international situation would be collected. How secure and accurate the implementation of a foreign policy will be, depends on the department's organization and spirit, as well as the quality of its staff." See Karović, Diplomacija, 66-67. 
enough. Apart from usual household items and things diplomats traditionally own, Bingulac's list included the furnishings of a study he was sending back, namely a desk, a piano, a radio phonograph, a large number of books, musicological materials and gramophone records. ${ }^{24}$

He did very well in the Political Department, but a note of "excellence" was missing in his report. ${ }^{25}$ Yet as early as 1935, he was accredited to the post of secretary at the Legation of the Kingdom of Yugoslavia in Prague on a ministerial order. ${ }^{26}$ Mere weeks later, his work was graded as excellent, with a commendation. His next promotion also awaited him in Prague, in 1937. ${ }^{27}$ Clearly the shift to diplomatic affairs was not very difficult for Bingulac, as his performance in Prague was invariably graded as excellent, with a note that he would accomplish every assignment most conscientiously and to the highest standard. ${ }^{28}$

After Czechoslovakia fell apart, the Sudetenland was annexed and Czechia ceased to exist, and with it the Legation in Prague. The crisis surrounding Czechoslovakia's borders in the Sudetenland was a prelude to WWII. Threatening with military intervention, Hitler asked for Czechoslovakia's richest region, the Sudetenland, and the Allies, Great Britain and France, accepted his demands at the Munich Conference on September 28, 1938, alleging they were protecting global peace. The Czechoslovakian territory was partitioned between Germany, Poland and Hungary. The country ceased to exist in March 1939, when the rest of Czechia was occupied by the Third Reich, and Slovakia became an independent state heavily dependent on it. On the eve of WWII, the Consulate General replaced the Legation

\footnotetext{
${ }^{24}$ AJ, 334-139, List of items (confidential) No. 929, the year 1934.

25 AJ, 334-139, Qualification Report for 1934, dated January 20, 1935, signed by Head of Legation Vladimir Martinac.

${ }^{26}$ The minister was Milan Stojadinović, serving from 1935 to 1939, who also had the leading position in the Ministerial Council. AJ, 334-139, Decree (confidential) No. 4451, dated October 2,1935 .

27 Promotions abroad were a taboo of sorts at the time, pretty much remaining so to date. They happen, but very rarely, while a diplomat serves a term in a foreign country. They are often used to reward a diplomat for exceptional, devoted work or, alternatively, as a sign of benevolence toward a diplomat in the top echelons of the ministry. AJ, 334-139, Decree (confidential) No. 984, delivered to the Legation in Prague on March 2, 1937.

${ }^{28}$ In our research, we explored Fond of the Ministry of Foreign Affairs at the Archives of Yugoslavia, but also parts of Fonds of the Consulate General of the Kingdom of Yugoslavia in Milan and the Legation of the Kingdom of Yugoslavia in Czechoslovakia-Prague [Poslanstvo Kraljevine Jugoslavije u Čehoslovačkoj - Prag, No. 391]. The two fonds were in complete archival disarray, comprising over 200 boxes of records altogether. As there is no inventory of fonds, we inspected a few boxes from each, some including documents signed by Petar Bingulac. In terms of form and content, they appeared to be regular diplomatic and consular correspondence, but the sample was so limited that we are unable to offer our opinion of Bingulac's diplomatic activity in the two cities without a more comprehensive insight into the archival holdings. That is why we need to rely on information that could be derived from his personal affairs and annual qualification reports.
} 
of the Kingdom of Yugoslavia, continuing to monitor the situation. Those were the circumstances surrounding Bingulac's appointment as Vice-Consul, working under a newly-appointed Consul General, Radovan Šumenković. ${ }^{29}$

There is a basic division in the diplomatic service into diplomatic and consular posts. Even though, as a rule, the former deal with political affairs and the latter represent the state administration, providing services to citizens, this is not always the case in practice, particularly back in Bingulac's day. Consular offices include those of a consul general, a consul and a vice-consul-as a deputy to the head of a consulate-as well as some lower consular ranks. The role of consulates and consulates general was similar to that of legations in parts of Europe and the world. The only difference was that a consulate was always working under the head of legation as a direct supervisor (and shortly before the war, the ambassador to the host country). Consulates dealt with political and diplomatic affairs alike. Bearing this in mind, the Consulate General in Prague was rather specific. It operated under the Embassy of the Kingdom of Yugoslavia in Berlin (as Germany was the state that occupied the Czech territory). The work of the Consulate General in Prague was essential from 1939 to April 1941, as it briefed the Kingdom of Yugoslavia's Ministry of Foreign Affairs, particularly on the military strength of the Third Reich and the position of the Czech people under occupation.

The complexity of the situation required Šumenković to travel frequently to Belgrade to provide for regular debriefings, and Bingulac would be running the Consulate General in his absence. Excellence in performance aside, Bingulac's 1939 grading report carried a special emphasis on his ability to collect classified and high-quality information. ${ }^{30}$ The next promotion, which made him a Consul,

${ }^{29}$ It's quite predictable that the Consulate General in Prague, shortly after the German occupation
of the Czech areas, would be working largely for intelligence purposes. When the WWII started
it was a convenient place to report on WWII developments in Central Europe, the number and
strength of German units included. For that reason Radovan Šumenković traveled to Belgrade for
quite frequent briefings. After Yugoslavia was attacked on April 6, 1941, the Kingdom's diplomatic
representative offices under direct control of the Third Reich were closed, and the staff interned on
the banks of Lake Constance. In June 1941 they were taken by train to the occupied capital Belgrade,
led by Ambassador Ivo Andrić (in violation of international norms, because all other diplomats, even
those coming from the states that attacked Yugoslavia together with Germany, had been evacuated
to neutral states). Few from the group of returnees were arrested by Gestapo as soon as they arrived
in Belgrade. Radovan Šumenković was the least fortunate of all, as he was accused of espionage and
sent to the Dahau concentration camp, barely surviving until the end of the war. Sumenković was
charged over an extremely bizarre case. A diplomatic representative of the "Independent State of
Croatia" moved into his official residence in Prague, where he found a hidden notebook containing
data on the strength of the German army in Prague, which was probably left behind by mistake after
the evacuation of the Consulate General in April that same year (1941). He delivered the notebook
to the German authorities and Gestapo accused Sumenković of espionage. It was certain that Petar
Bingulac was also involved in intelligence collection, and what "saved" him from imprisonment was
probably the fact that he was already in a camp for officers. ${ }^{30}$ AJ, 334-139, Qualification Report for 1939, dated January 9, 1940. 
followed early in 1940, when he was still in Prague. ${ }^{31}$ He kept monitoring the political situation in Central Europe as the German occupation of not only Czechia, but also Poland, was unraveling, creating an unconditional political affiliation by the rest of the region-particularly the newly-created Slovakia. Bingulac also witnessed the occupation of not only Czechia and Moravia, but also Poland.

In late 1940, Petar Bingulac moved to Belgrade, re-joining the Political Department in mid-October. ${ }^{32}$ Detailed lists of the items he had sent back to Belgrade are preserved. ${ }^{33}$ Among other things, a drawing room with a radiogram, a piano, a radio, a library and crates with books, sheet music and gramophone records came back from Prague.

Although he returned to Belgrade less than six months before the whirlwind of war reached the Kingdom of Yugoslavia, no records are available as to his career movements in that brief period, as the archives covering the work of the Ministry of Foreign Affairs at the time were extremely fragmented. Bingulac's grade for 1940 is lost (just like his personal file for that matter), ${ }^{34}$ but our guess is that he responded to a draft call in early 1941, since he was captured as a reserve officer and transferred between several officers' camps.

The interesting thing is that unlike other former employees of the Ministry of Foreign Affairs of the Kingdom of Yugoslavia, Petar Bingulac sent into retirement from the position of secretary at the Ministry of Foreign Affairs (position level $\mathrm{V})$ after 18 years and six months of service, the years in captivity included. The

\footnotetext{
31 AJ, 334-139, Decree (confidential) No. 1325, dated March 13, 1940. The promotion made as a global war was simmering close to the geographical jurisdiction of the Consulate General in Prague was by all means an extraordinary appraisal of Petar Bingulac's work, but it also reflected the necessity for high-quality diplomats who found themselves in war-affected territories not be replaced in such circumstances, but rather that their status be solidified in the host countries, i.e. the Third Reich.

32 AJ, 334-139, Decree (confidential) No. 4322, dated August 21, 1940, not enforced until October 1940.

${ }^{33}$ AJ, 334-139, Certificate No. 1348/40 issued by the Consulate General in Prague.

${ }^{34}$ The fact that Bingulac's personal file is missing from the foreign ministry's personnel records is not an exception, but rather a rule of sorts. It is hard to tell why, but there is a degree of certainty in the assumption that some personal files were taken by the occupation authorities if related to persons of interest. Also missing were the personal files of the Milikić brothers, Ilija, the head of Section IV of the Political Department, and Aleksandar, a young diplomat. Parts of the file of Aleksandar Bodi, a head of legation, are also missing. We know that in those three cases, the Gestapo took the files to carry out an investigation over allegations of espionage for the Allies. As other files belonging to people interned to officers' camps are also gone, we can assume that they, too, were taken by the German occupation authorities. There is also a third category of missing files we came across while examining the Archives of Yugoslavia-those of people (very few by all means) who joined the government structures of the new Democratic Federative Yugoslavia.
} 
decision on his retirement was made by Milan Nedić's collaborationist cabinet in late March 1944, while Bingulac was still imprisoned. ${ }^{35}$

As the war was nearing its end in the Balkans and the fundamentals of a new Yugoslavia were being built, Bingulac returned from the camp together with writer Stevan Jakovljević ${ }^{36}$ in April 1945. From that period, we have found an illustrative excerpt from a diary of another diplomat, Kosta St. Pavlović: "Friday, April 27, 1945 [...] A Yugoslav National Liberation Committee was established at the Ministry of Foreign Affairs, as well as within all other ministries. It's a local soviet for the 'Yellow House.' The chair is Petar Bingulac (his wife has always been considered a Communist), and members completely unknown clerks. They must be some novel Communists. It must be that they'll be the ones who choose which clerks will stay which will go." ${ }^{37}$

Petar Bingulac's role in ensuring the appropriate staffing of the newly-formed ministry is unrecorded, and we cannot be sure if he had any. But what we do know is that he soon devoted himself fully to music, never to return to diplomacy again, sharing the same fate with many older and more experienced peers-first and foremost Ivo Andrić ${ }^{38}$ - who switched to career areas they had been far less engaged in between the two wars. For him it was musicology, which he approached as a music critic and researcher. Had WWII not broken out, Petar Bingulac would have gone down in history as a diligent diplomat who would always put the interests of the state before anything else. But by a curious twist of fate, the world was able to also see his artistic side and versatile talents, and Bingulac was able to leave an indelible mark on Serbian musicology.

${ }^{35}$ AJ, 334-139, Act No. 630 issued by the Presidency of the Ministerial Council to the Ministry of Finance, dated March 3, 1944.

${ }^{36}$ Stevan Jakovljević was a celebrated pre-war writer who earned his literary fame as the author of Srpska Trilogija (The Serbian Trilogy), describing the suffering of the Serbian people during the Great War. Jakovljević was a professor at the Belgrade Faculty of Pharmacy.

37 Kosta St. Pavlović, Ratni dnevnik, 1945-1946 [A War Diary 1945-1946] (Belgrade: Istorijski arhiv Beograda, 2017), 95. The author's bitter remark about Petar Bingulac's wife is largely a consequence of small-town ignorance. Using a more contemporary term, Anđa Bingulac was one of the most prominent Serbian feminists of the day. She was the first female professional journalist at Politika, the founder of the Association of Women with University Education in Yugoslavia (1927) and a member of its governing committee. After Queen Maria Karađorđević, she was the first woman to have a driving license in Yugoslavia. Anđa Bunuševac-Bingulac could not possibly fit the predominant patriarchal view of the world. Her first husband was Nikola Kotur, an architect and a political secretary of the League of Communist Youth of Yugoslavia (SKOJ), killed during the Moscow Trials in the 1930s. Even though it was a brief marriage and the two were already separated when he fled for the Union of Soviet Socialist Republics (USSR), she continued to be labeled a Communist.

38 See more in Ratomir Milikić, “Ivo Andrić’ o Žutoj kući,” 57-68. 


\section{Primary sources:}

Archives of Yugoslavia (AJ) (Belgrade): Ministry of Foreign Affairs of the Kingdom of Yugoslavia; Consulate General of the Kingdom of Yugoslavia in Milan; Legation of the Kingdom of Yugoslavia in Czechoslovakia-Prague

\section{References:}

Car, Pavel, Muhić, Tomislav. Odlikovanja Srbije i Jugoslavije od 1859. do 1941. Vienna: Verlag Militaria, 2012.

Karović, Pavle. Diplomacija. Belgrade: Geca Kon, 1937. [Orig. in Serbian Cyrillic]

Mićić, Srđan. Od birokratije do diplomatije - Istorija jugoslovenske diplomatske službe 1918-1939. Belgrade: Institut za noviju istoriju Srbije, 2018. [Orig. in Serbian Cyrillic]

Milikić, Ratomir. "Nepokretno i pokretno kulturno nasleđe Srba u Francuskoj iz dva svetska rata: pomoć Francuske Srbiji kroz likovnu umetnost 1914-1916. godine i oficirski logor u Strazburu (1944)." In Očuvanje i zaštita kulturno-istorijskog nasleđa Srbije $u$ inostranstvu, edited by Vidoje Golubović, Branislav Đorđević, 312-327. Belgrade: Institut za međunarodnu politiku i privredu, 2017. [Orig. in Serbian Cyrillic]

Ko je ko u Jugoslaviji. Belgrade-Zagreb: Jugoslovenski godišnjak, Nova Evropa, 1928.
Milikić, Ratomir. “Ivo Andrić” o Žutoj kući ili jedan denuncijantski pamflet o Ministarstvu inostranih poslova Kraljevine Jugoslavije." Istorija 20. veka I (2018): 57-68.

Pavlović, Kosta St. Ratni dnevnik, 1945-1946. Belgrade: Istorijski arhiv Beograda, 2017. [Orig. in Serbian Cyrillic]

Pantić, Branislav J. Banditsko-komunistički logor 1945. Sidney: s.n., 1964.

Senat, Narodna skupština (biografski leksikon), edited by Č. Mitrinović, Skopje: Nemanja, 1935. [Orig. in Serbian Cyrillic and French]

Simić, Milutin. Hram svetog Save u okolini Strazbura. Belgrade: Čigoja štampa, 2000.

Stajić, Staja. Dva miliona minuta do slobode. Belgrade: Prosveta, 1963.

Vinaver, Stanislav. Godine poniženja i slobode. Život u nemačkim oflazima. Belgrade: Prosveta, 1945. [Orig. in Serbian Cyrillic] 


\section{Part II.}

\section{Reflections of Foreign Policies in National Music Spheres}





\title{
Musical life in Belgrade as an instrument of global political polarization on the eve of WWII
}

\author{
Ranka Gašić
}

International relations in the 1930s were characterized by disintegration of the international order established at the Versailles Peace Conference, which marked the end of WWI. The political rupture between the Third Reich on one side and the socalled Western democracies (Great Britain and France) on the other was escalating rapidly. The Yugoslav government was striving to uphold its position of neutrality. However, the international context - the country's relations to the war allies (Britain and France) and its membership in the Little Entente (a defensive alliance between Yugoslavia, Romania and Czechoslovakia) — did have a significant impact on social and cultural life in the country. The dominant cultural models were coming from Western and Central Europe. German culture exercised an influence for a long time. In the $19^{\text {th }}$ century, it was Austrian culture that left a significant mark on the Serbian society, and the German cultural contents and models continued even after the bitter experience of WWI. However, political use of culture in this respect was appearing gradually and reached its peak at the time when WWII broke out in 1939. Cultural influences in Yugoslavia took a turn in 1934, when the assassination of Yugoslav King Alexander I in France ended the era of French-dominated influence, which was then supplanted by the British one. By the eve of WWII, the cultural life in Belgrade had become a theater of fierce competition between the Third Reich and Great Britain.

Music was perhaps the least developed form of art in interwar Belgrade. Before WWI, musical life in Belgrade was shaped by choral societies and a small number of music schools. Most music institutions were founded only after 1918the Belgrade Philharmonic in 1923, the South Slav Choral Union in 1924, the Collegium Musicum in 1926, and the Music Academy as late as 1937. Therefore, in the case of 1930s Belgrade, music was perhaps the least suitable means of cultural and political propaganda. However, the developments in international politics did in fact have an impact on the musical life in Belgrade, due to the activities of several associations dealing with cultural propaganda: the German Academy in Munich, the British Council in London, and the bilateral societies in Belgrade dealing with the implementation of the cultural policies formulated abroad and with organizing cultural events. From 1939 on, when a propaganda, economic 
and intelligence warfare between the Third Reich and Britain was underway in Belgrade, both countries established their institutes for general coordination of cultural propaganda activities. In the case of Germany, this was done by direct contact between state representatives (press attaché of the Yugoslav Embassy in Berlin and the president of the German Academy), whereas the British Council collaborated closely with the Anglophile societies in the country. ${ }^{1}$

In the two interwar decades, the German cultural influence underwent a great change. In 1921, Vienna-based pianist Moriz Rosenthal encountered a very unwelcoming treatment from the Belgrade audience, which demonstrated openly the hostility toward his homeland, and violinist Sigmund Feuermann played in front of an almost empty concert hall. ${ }^{2}$ However, the same year (1921), certain intellectual circles began working toward the renewal of cultural relations between Germany (then Weimar Republic) and Serbia (then Kingdom of Serbs, Croats and Slovenes). The German-Yugoslav Society was established in Frankfurt am Main, under the leadership of politician and historian Herman Wendel. ${ }^{3}$ It engaged in various cultural activities, including musical soirees. ${ }^{4}$ In 1930, a similar Yugoslav-German Society was established in Belgrade, which also undertook the organizing of "music shows." ${ }^{5}$ However, in the late 1930s, all Yugoslav-German Societies were subordinated to the German Ministry of Foreign Affairs. To that end, a German Scientific Institute was set up in 1940. Cultural activities instigated by the German cultural propaganda institutions were held across the country, always including German settlements in Vojvodina. Rikard Švarc, a renowned Belgrade music critic, in his otherwise very affirmative review of the concerts by the Magdeburg Madrigal Singers in Belgrade and several towns in Vojvodina in the autumn of 1935 nevertheless commented on the propaganda character. ${ }^{6}$

\footnotetext{
1 See Ranka Gašić, Beograd u hodu ka Evropi. Kulturni uticaji Britanije i Nemačke na beogradsku elitu 1918-1941 [Belgrade on the Way to Europe: Cultural Influences of Britain and Germany on the Belgrade Elite 1918-1941] (Belgrade: Institut za savremenu istoriju, 2005); Ranka Gašić, "Srpska kultura između dva svetska rata [Serbian culture between the two World Wars]," Istorija 20. veka 2 (2008): 162-182.

2 Radina Vučetić-Mladenović, Evropa na Kalemegdanu: "Cvijeta Zuzorić” i kulturni život Beograda 1918-1941 [Europe in Kalemegdan. "Cvijeta Zuzorić" and the Belgrade Cultural Life 1918-1941] (Belgrade: Institut za noviju istoriju Srbije, 2003), 99-100; Stanislav Vinaver, "Muzički život [Musical life]," Misao VI/56 (1921): 416.

3 The Political Archive of the Federal Foreign Office [Politisches Arhiv des Auswaertigen Amtes (PA-AA)] Bonn, Cultural-Political Department [Kultur-Politische Abteilung (Kult-Pol)] VI W R 65793, Statute of the Yugoslav-German Society, 4; PA-AA, Bonn, Kult-Pol VI W R 65793, The correspondence of the German Foreign Ministry from 1929, 1930 and 1931.

4 PA-AA, Bonn, Kult-Pol VI W R 65793, Statute ..., 2.

5 PA-AA, Bonn, Kult-Pol VI W R 65798, Annual report of the Yugoslav-German Society's Board for the 1932/1933, Annual report ... 33/34; Annual report ... 1938.

6 Rikard Švarc, "Muzika u zemlji [Music around the country]," Zvuk 8-9 (1935): 319. On the work of Rikard Švarc, see Aleksandar Vasić, "Muzički kritičar Rikard Švarc [Rikard Švarc, the music critic]," Zbornik Matice srpske za scenske umetnosti i muziku 61 (2019): 87-103.
} 
It was not until the late 1930s that more important guest performances by German musicians took place-those of the Frankfurt Opera (1938), the Dresden String Quartet (1940), the Munich String Trio (1940), the Berlin Philharmonic Chamber Orchestra and the Vienna Boys' Choir (between 1937 and 1940). ${ }^{7}$ As the war was approaching, the Yugoslav authorities were trying not to align the country too closely with the Third Reich and consequently jeopardize its neutrality. So Radio Belgrade and the Belgrade Music Academy took part in organizing the Munich String Trio's performances in late 1940, together with the German Scientific Institute, while on the other hand, the Yugoslav Ministries of Foreign and Internal Affairs expressed their disapproval with the organizing of the Dresden String Quartet's concerts in the spring of 1940 "in view of the political situation." Although the ministries did not officially ban the concerts, they kept track of the people who attended them. ${ }^{8}$

The guest performances of the Frankfurt Opera in 1938 were a major event for Belgrade at the time. Several of its members were awarded with high Yugoslav decorations. ${ }^{9}$ On that occasion, Pavle Stefanović, a prominent music critic, published in Glasnik Muzičkog društva "Stanković" (Stanković Music Society Herald) two very positive reviews of their performances of Le nozze di Figaro (The Marriage of Figaro), Der Rosenkavalier (The Rose-Bearer) and Die Walküre (The Valkyrie). These reviews were, however, accompanied with a commentary on the international political context. Relating to "the motives of cultural and political propaganda of the extremely expensive and massive undertaking of the Third Reich's Frankfurt Opera, which, by venturing an excursion to the cultural centers of Romania and Yugoslavia, virtually degraded itself," Stefanović writes about mass emigration of Jewish and other politically unsuitable musicians from the Third Reich, the country where "Hindemith was silenced." He believed that this musical event was an attempt to "atone for the bad impressions made on the international community by the abominable treatment of art in that country."

The persecution of Jewish musicians in the Third Reich also left its mark on the Belgrade musical life. The Hanigun Jewish Choral Society, composed of Jewish opera singers who fled Germany held three concerts in Belgrade in 1934, performing Jewish sacred and folk music. ${ }^{10}$ German opera director and conductor of Jewish origin Erich Hetzel (1899-1944) studied drama, music and literature, and

\footnotetext{
7 Archives of Yugoslavia [Arhiv Jugoslavije (AJ)], Ministarstvo prosvete Kraljevine Jugoslavije [Ministry of Education of the Kingdom of Yugoslavia], 66-454-718, Report on the activities of the Department for International Cultural Relations.

8 AJ, 66-374-610, Letter of the Minister of the Interior to the Ministry of Education, March 22, 1940.

9 AJ, 66-344-582, Ministry of Education enactment, May 1938.

10 Rikard Švarc, "Muzika u zemlji. Beograd. (Orguljski koncert Jurija Arbatskog. Amaterski orkestar Lira. Jevrejsko vokalno udruženje Hanigun. Glasbena matica iz Ljubljane) [Music around the
} 
worked in various German theaters before emigrating to Belgrade in 1933. He was employed by the Opera of the Belgrade National Theater in 1934 as professional opera director. He was a representative of the German modern-style opera direction. While in Belgrade, he had the opportunity to stage ten operas of very different styles-from the $18^{\text {th }}$ century to the modern-day operas by Richard Strauss and Dmitri Shostakovich. His stagings of Wagner's operas in Belgrade were based on the latest versions from the Bayreuth Festival and Wieland Wagner's innovations. He directed several of the most successful opera performances in Belgrade on the eve of WWII-The Merry Wives of Windsor, Gianni Schicchi, Tannhauser and Don Quixote. ${ }^{11}$ During the Nazi occupation of Belgrade (1941-1944) he was in hiding, only to be killed in the Allied bombing of Belgrade in April 1944. ${ }^{12}$ Another opera director of Jewish origin was Joseph Krisp (1902-1974) from Austria, director of the Vienna State Opera and the Vienna Philharmonic Orchestra who fled to Belgrade in 1938, after the Anschluss. He was engaged as a guest director at the Opera of the Belgrade National Theater for the 1938/39 season. There he conducted Mozart's Le nozze di Figaro and Die Zauberflöte (The Magic Flute), Verdi's Un Ballo in Maschera (A Masked Ball), La Traviata, Aida, Il Trovatore (The Troubadour), Puccini's Madama Butterfly, Rossini's Il barbiere di Siviglia (The Barber of Seville), Smetana's Prodaná nevěsta (The Bartered Bride), and Mussorgsky’s Boris Godunov. He was later praised by music critics for his significant contribution to the overall professional level of the Belgrade Opera. ${ }^{13}$

The opposition of Belgrade intellectual circles to the government's Germanophile policy was also plainly demonstrated in the case of the Obilić Academic Choral Society's tour to Germany, which was planned for 1936 and was canceled at short notice. In his report to the German Foreign Ministry, German Ambassador to Yugoslavia Victor von Heeren referred to "Francophile university

country. Belgrade. (Organ concert by Yury Arbatsky. The Lira amateur orchestra. The Hanigun Jewish Vocal Society. Musical society Glasbena matica of Ljubljana]," Zvuk 6 (1934): 233-234.

${ }^{11}$ Stana Đurić-Klajn, "Muzički život u Beogradu između dva rata [Musical life in Belgrade between the two world wars]," in Istorija Beograda III, edited by Vasa Čubrilović (Belgrade: SANU, Prosveta, 1974), 398-409, 402.

12 Aleksandar Radovanović, Pregled istorije Narodnog pozorišta u Beogradu 1868-1993 [Overview of the history of the National Theater in Belgrade, 1868-1993] (Belgrade: Narodno pozorište, Institut za književnost i umetnost, 1994), 70, 82; Roksanda Pejović, Opera i balet Narodnog pozorišta u Beogradu (1882-1941), (Belgrade, 1996), 119-121, 241-244; Nadežda Mosusova, "Srpska muzička scena (125 godina Narodnog pozorišta) [Serbian musical scene (125 $5^{\text {th }}$ anniversary of the National Theater)]," Srpska muzička scena. Zbornik radova sa naučnog skupa održanog od 15. do 18. decembra 1993. godine povodom 12-godišnjice Narodnog pozorišta, edited by Ana Matović, Nadežda Mosusova, Ranko Ivančević (Belgrade: Muzikološki institut SANU, 1995), 5-37, 25.

${ }^{13}$ Pejović, Opera i balet, 235, 255-256; Raško Jovanović, Olga Milanović, Zoran Jovanović, 125 godina Narodnog pozorišta u Beogradu [125 th anniversary of the National Theater in Belgrade] (Belgrade: SANU, 1994), 203; Aleksandar Radovanović, Pregled istorije Narodnog pozorišta, 79. 
professors," particularly historian Vladimir Ćorović, and "their influence on members of the Choral Society," recommending, at the same time, that another attempt be made to organize the canceled Obilić tour. ${ }^{14}$ However, it was not Corović, but Branko Dragutinović, the conductor of the Choral Society at the time, who instigated this short notice cancelation. He became a freemason the same year. As a correspondent for masonic magazines Javnost and Vidici, he frequently published articles on the oppression of Jewish and other artists in the Third Reich. ${ }^{15}$

Musicians from Belgrade took part in three international competitions in Vienna (in 1933 and 1937) by invitation of the Austrian Embassy, the University of Music and Performing Arts and distinguished Vienna musicians. In 1933, Belgradebased composers Petar Krstić and Josip Štolcer Slavenski were members of the jury at the international piano and singing competition in Vienna. Yugoslav participants were very successful in this competition, and Vienna State Opera director Klemens Kraus was awarded a high Yugoslav decoration on this occasion. ${ }^{16}$ At the time of the most intensive state-sponsored international cultural activity (1937-1940), there were only three guest performances of Belgrade musicians in Germany: the Opera of the Belgrade National Theater, the Ballet of the Belgrade National Theater, and the private ballet company_Students' Folk Company_led by Maga Magazinović at the Hamburg Folk Festival in July 1939. ${ }^{17}$ Yugoslav authorities insisted on the principle of equal quality of guest performances in terms of musicians' skills and reputation, which was almost impossible in the case of two so very different cultural and social milieus. A guest performance of an operetta company from Vienna was declined by the Ministry of Education in June 1939, for being "below the artistic level that was

\footnotetext{
${ }^{14}$ AJ, The Central Press Agency [Centralni Presbiro], 38-49-108, Report of the Agency's correspondent M. Crnjanski for the first half of 1937; PA-AA, Bonn, Kent III, Political Department [Politische Abteilung] IV, 103320, 001, Ambassador von Heeren to the German Ministry of Foreign Affairs, May 14, 1936.

${ }^{15}$ Music critic Branko M. Dragutinović (Belgrade, 1903-1971) attended a music school in Belgrade and studied music history at the Belgrade University. His professor was Miloje Milojević, a distinguished Serbian composer. From 1925 to 1938, he was the conductor of the Obilić Academic Choral Society. He worked as secretary of the Belgrade Opera from 1938 to 1940, and as a high school lecturer until 1944. After 1945 he taught at the Belgrade Music Academy, and worked as an assistant director of the Opera from 1950. He was continuously active as a music critic from 1926 on, and published articles in different Belgrade-based journals and magazines. ("Branko Dragutinović," Leksikon jugoslavenske muzike I (Zagreb: JLZ Miroslav Krleža, 1984), 203-204.) He became a member of the Dositej Obradović Masonic Lodge in 1936. See Zoran D. Nenezić, Masoni u Jugoslaviji 1764-1980 [Freemasons in Yugoslavia, 1764-1980] (Belgrade: Narodna knjiga, 1984), 573.

16 AJ, 66-374-610, Ministry of Education enactment, 1933.

17 AJ, 66-454-718, Report of the Department for International Cultural Relations; AJ, 38-141-414, Press articles on the Maga Magazinović German Tour; Gojko Miletić, "Međunarodna afirmacija Narodnog pozorišta [International affirmation of the National Theater]," in Jedan vek Narodnog pozorišta u Beogradu 1868-1968, edited by Milan Đoković (Belgrade: Narodno pozorište, Nolit, 1968), 554-571.
} 
agreed upon" between Yugoslav and German ministries. Since the Belgrade Opera had already performed in Frankfurt, a private operetta company was considered to be below that artistic level. ${ }^{18}$ Many prominent opera singers from Belgrade performed in Germany at the time, such as Zlata Đunđenac, Anita Mezetova, Janja Vasiljeva, Krsta Ilić and Vladeta Popović. Melanija Bugarinović was one of the few who took part in Wieland Wagner's Bayreuth Festival. Bahrija Nuri Hadžić also had a very successful career in German-speaking countries, performing in Vienna in 1934 and 1938, and in Zurich in 1939. ${ }^{19}$

On the other hand, the most influential factors of the British cultural propaganda were Anglophile associations and Radio Belgrade.

The large number of Anglophile intellectuals and activists in Belgrade was organized into three bilateral societies: the Anglo-American-Yugoslav Club (established in 1924), the Society of Friends of Great Britain and America (1930), the Society for Promoting Anglo-Saxon Culture in Yugoslavia (1935), as well as two more associations dealing with cultural relations with Britain (the Society of Former British Students, and the Society of Students of English Language and Literature). ${ }^{20}$ After June 1940, all Anglophile activities were coordinated by the Yugoslav British Institute.

Local musicians had long since been familiar with German and generally Central European cultural centers and music. This was, however, not the case with Britain and Anglo-American culture. English music was almost completely unknown to the Belgrade audience. Although performances by British (and even more so American) musicians were rare after WWI, their frequency rose significantly precisely in the late 1930s. British and American musicians held several concerts in Belgrade, organized by the Anglophile societies, starting from 1929. In December 1929, British pianist Frederic Lamond performed at the Stanković Music School Hall, and in the following year Utica Jubilee Singers from the US gave a concert at Hotel Kasina. Also in 1930, the efforts of composer Kosta Manojlović, a former British student, in his capacity as the Secretary General of the South Slav Choral Union, made is possible to organize a tour of an orchestra composed of fifty British musicians throughout Yugoslavia. ${ }^{21}$ In December 1933, the Society of Friends of Great Britain and America, together with the Belgrade branch of the

\footnotetext{
18 AJ, 66-454-718, Report of the Department for International Cultural Relations, June 15, 1939. ${ }^{19}$ AJ, 66-454-718, Report of the Department for International Cultural Relations, 1934, 1938, 1939; Jovanović, Milanović, Jovanović, 125 godina Narodnog pozorišta, 221; Mirka Pavlović, "Veličina iz Beograda - Bahrija Nuri Hadžić (1904-1993) [A star from Belgrade-Bahrija Nuri Hadžić (1904-1993)]," in 125 godina Narodnog pozorišta u Beogradu. Zbornik radova sa naučnog skupa održanog 16-19. novembra 1994, edited by Stanojlo Rajičić (Belgrade: SANU, 1997), 417-437.

${ }^{20}$ Milan Milojević, Anglo-Yugoslav Cultural Relations (London: s.n., 1944), 7, 11.

${ }^{21}$ AJ, 66-374-610, Concert of the Utica Jubilee Singers from the USA; AJ, 38-73-197, The guest performance of English Musicians' Group in August 1930, September 1930; Esther Johnson's petition, AJ, 66-374-610, October 1933.
} 
YMCA, organized a concert of the First Belgrade Choral Society at an English Evening, followed by a Shakespeare recital. ${ }^{22}$ In order to further promote AngloSaxon culture, the Anglophile societies organized an English Week in Belgrade (October 1934), which closed with an English Musical Evening. ${ }^{23}$ The Mokranjac Choral Society always took part in annual celebrations of the "Anglo-American Day" (i.e. Armistice Day, November 11) from 1935 on. ${ }^{24}$

All the guest performances by both British and American musicians in the late 1930s were organized by the British Council in collaboration with the Society of Friends of Great Britain and America. One of them was Esther Johnson's concert in October 1938, when the American pianist played contemporary Yugoslav art music among other pieces. Both British and American musicians expressed their interest in Yugoslav folk music. Hugh Ross, a British-born American conductor of the Schola Cantorum of New York, consulted the Yugoslav authorities in 1938 for the purpose of selecting Yugoslav folk songs and dances to be presented at the World Exhibition in New York. ${ }^{25}$ A few years earlier, in 1932, British folk song collector Julia Chatterton came to Yugoslavia in search of material for her folk music anthology. ${ }^{26}$

British musicians performed mostly English, both art and folk music in Belgrade. In February 1937, the Fleet Street Choir performed a set of English songs at the Kolarac University and the Manjež Theater, and bass-baritone singer Keith Falkner gave a concert of modern English serious music together with pianist Cyril Smith. In 1939, English folk singer Ethel Lewis gave two recitals at the Anglo-Yugoslav Club and the Music Academy, which were broadcast by Radio Belgrade. ${ }^{27}$ On the very eve of WWII, in May 1939, the US Ambassador to Belgrade gave an introductory speech on Yugoslav-American relations, opening a concert of American modern music in Belgrade. The performers were American musicians accompanied by the Radio Belgrade Symphony Orchestra. 28

\footnotetext{
22 "An English Evening," South Slav Herald (December 1, 1933): 5.

23 "An English Week," SSH (October 3, 1934): 1.

24 “An English Week," SSH (May 16, 1934): 1; “An English Week," SSH (October 3, 1934): 1; "Armistice Day 1935," SSH. (November 16, 1935): 1; "Armistice Day in Belgrade," SSH (November 16-30, 1936): 2.

${ }^{25}$ AJ, 66-374-610, Letter of the Yugoslav Consul General in New York, B. P. Stojanović, to the Ministry of Education, August 1938.

26 "English Composer in Belgrade," SSH (May 17, 1932): 1.

27 "Sir Hamilton Harty," SSH (November 1-16, 1936): 2; "Music-Art-Theatre in Yugoslavia," SSH (February 18-28, 1935): 5; "Belgrade Calling," SSH (February 1-16, 1937): 2; "Belgrade Calling," SSH (October 1, 1938): 1; "Ester Johnson's Concert," SSH (December 16, 1932): 2; AJ, 38-73-197, Bulletin of the Anglo-American-Yugoslav Club, January 1939; AJ, 38-73-197, Bulletin of the AngloAmerican-Yugoslav Club, January and February 1940.

28 AJ, The collection of the Society of Friends of Great Britain and America [Udruženje prijatelja Velike Britanije i Amerike u Jugoslaviji] (342), Report of the Society's Board, May 31, 1939.
} 
Radio was a modern cultural propaganda medium which few citizens of Yugoslavia could afford in that time. On July 15, 1924 a Radio Club was founded in Belgrade. Its members were mostly young people from the upper middle class, state officials, academics, university professors, engineers and doctors. These amateur radio enthusiasts helped the process of widening the radio network and increasing the number of then very expensive radio sets. The radio subscription rate in Yugoslavia was the lowest in Europe (only 0.3\% in 1933). ${ }^{29}$ With a total of 100,000 radio sets in Yugoslavia on the eve of WWII, radio was accessible only to the upper middle class. ${ }^{30}$ Radio Belgrade was established as a joint-stock company in March 1927. It was granted a concession for fifteen years, so in August 1940 the company was taken over by the state. The majority stockholder was Julius Hanau, a representative of the Marconi Wireless Co., incidentally also a high-profile British intelligence agent. Radio Belgrade Inc. is a very good example of global political polarization in terms of capital investment and cultural propaganda. As a new and expensive medium, Radio Belgrade was financed and technically equipped exclusively by foreign capital. For example, in April 1933, 98\% of the shares were owned by British citizens. ${ }^{31}$

In the years just before WWII, editors at Radio Belgrade were connected in different ways with either Anglophile circles or with the official government policy toward the Third Reich. This also reflected in the music programing of Radio Belgrade. There were many broadcasts of musical events in Austria and Germany, like the Salzburg Music Festival or the Bayreuth Festival. The Salzburg Music Festival was regularly broadcast. The opera radio program was very versatile: it covered a wide range from Gluck's Orpheus to R. Strauss' Salome and Shostakovich's Katerina Izmaylova. The first edition of the Great Opera Evening series was broadcast on June 2, 1929, featuring Wagner's operas performed by the Belgrade National Theater Opera. From 1935, the Radio Belgrade Orchestra performed operas and symphonic concerts in the studio. ${ }^{32}$

The concerts by English and American musicians in Belgrade were often broadcast by the Radio. When the British cultural propaganda in Yugoslavia intensified in 1937, the Radio Belgrade's board of directors was changed, and Mihailo Vukdragović was appointed conductor and music director of the Radio

\footnotetext{
29 "Special Radio Features in This Issue," SSH (November 1, 1933): 1.

${ }^{30}$ Radivoje Marković, "Prve godine [The first years]," in Ovde Radio Beograd. Zbornik povodom pedesetogodišnjice, edited by Milan Bulatović et al. (Belgrade: Radio Beograd, 1979), 11-29; Milan Bulatović, "Do celovitog sistema pet programa [Before the system of five programs was built]," in Ovde Radio Beograd, 37-51.

${ }^{31}$ Marković, "Prve godine," 13-14.

${ }^{32}$ Ljubomir Kocić, Ljubinko Miljković, “Tragovima sazvučja muzike [Following the musical harmonies]," in Ovde Radio Beograd. Zbornik povodom pedesetogodišnjice, edited by Milan Bulatović et al. (Belgrade: Radio Beograd, 1979), 103-129.
} 
Belgrade Orchestra. As an antifascist and a freemason, he-together with Vojislav Vučković-left a significant mark on Radio Belgrade's musical program. Armistice Day celebrations were also regularly broadcast. On March 31, 1938, the Radio Belgrade Symphony Orchestra, conducted by Vukdragović, gave a concert of modern American music, organized by the Society of Friends of Great Britain and America, and the National Federation of Music from North Dakota (US). Vukdragović took this opportunity to acquire written music of modern American composers to be performed in Belgrade in the autumn of 1938. ${ }^{33}$

By 1940, Yugoslavia was already forced into the political sphere of the Third Reich. After that, the shares of Radio Belgrade Inc. were taken over by the state, which consequently led to a replacement of its music director. Kosta Manojlović was now appointed to the post, together with Stevan Hristić and Svetomir Nastasijević. ${ }^{34}$ Radio Belgrade now broadcast more music performances by German musicians, such as the one by the Berlin Philharmonic Chamber Trio on May 19, 1940. After that, out of the total of 46 music radio broadcasts of foreign musicians' performances, 15 were German, 13 Hungarian and none were English. Radio Belgrade not only broadcast, but also organized concerts of German musicians-like the one by Maria Nemet, a soloist of the Vienna State Opera on January 3, 1941. ${ }^{35}$

The position of Yugoslavia in international relations in the 1930s and the global political rupture took their toll on the musical life in Belgrade. On the one hand, propaganda activities were also engineered in the centers of political power abroad-such as propaganda tours of German musicians in Belgrade but also in Vojvodina, as well as the efforts of the British Council to organize concerts of British and also American musicians. Also important was the attitude of the Belgrade audience and the creators of cultural policies toward the political developments in Europe, such as the persecution of Jewish artists in the Third Reich. This attitude was clearly manifested in the acts of welcoming Jewish musicians, canceling Obilic's German tour, intensive Anglophile activities in the late 1930s, cooperation with English and American performers, and finally, the musical radio program as a reflection of the competing foreign capital and the Yugoslav government's delicate handling of international relations in the 1930s.

\footnotetext{
33 AJ-342, Report to the Society's Annual Assembly, May 1938.

${ }^{34}$ Kocić, Miljković, “Tragovima sazvučja muzike," 111. Hristić was a grandson of the $19^{\text {th }}$-century politician Nikola Hristić. He studied in Leipzig and other places in Germany, and later worked as a professor at the Belgrade Music Academy. See Nadežda Mosusova, "Mesto Stevana Hristića u jugoslovenskoj i evropskoj muzici [Stevan Hristić in the context of Yugoslav and European music]," in Život i delo Stevana Hristića: zbornik radova sa naučnog skupa održanog 19. i 20. novembra 1985. povodom 100-godišnjice kompozitorovog rođenja, edited by Dimitrije Stefanović (Belgrade: SANU, 1991), 1-7. ${ }^{35}$ AJ, 66-374-610, Report on the Radio Belgrade program to the Ministry of Education.
} 


\section{Primary sources:}

Archival sources

Archives of Yugoslavia (AJ) (Belgrade): Ministry of Education of the Kingdom of Yugoslavia; Central Press Agency; Society of Friends of Great Britain and America

The Political Archive of the Federal Foreign Office (PA-AA) (Bonn/Berlin): Cultural-Political Department; Kent III, Political Department IV
Press and Periodicals

South Slav Herald, Belgrade, 1932-1941

Zvuk, Belgrade, 1932-1936

\section{References::}

"Branko Dragutinović." Leksikon jugoslavenske muzike I. Zagreb: JLZ Miroslav Krleža, 1984, 203-204.

Bulatović, Milan. "Do celovitog sistema pet programa." In Ovde Radio Beograd. Zbornik povodom pedesetogodišnjice, edited by Milan Bulatović et al., 37-51. Belgrade: Radio Beograd, 1979. [Orig. in Serbian Cyrillic]

Đurić-Klajn, Stana. "Muzički život u Beogradu između dva rata. In Istorija Beograda III, edited by Vasa Čubrilović, 398-409. Belgrade: SANU, Prosveta, 1974. [Orig. in Serbian Cyrillic]

Gašić, Ranka. Beograd u hodu ka Evropi. Kulturni uticaji Britanije i Nemačke na beogradsku elitu 1918-1941. Belgrade: Institut za savremenu istoriju, 2005.

Gašić, Ranka. "Srpska kultura između dva svetska rata," Istorija 20. veka 2 (2008): 162-182. [Orig. in Serbian Cyrillic]

Jovanović, Raško, Milanović, Olga, Jovanović, Zoran. 125 godina Narodnog pozorišta u Beogradu. Belgrade: SANU, 1994. [Orig. in Serbian Cyrillic]

Kocić, Ljubomir, Miljković, Ljubinko. “Tragovima sazvučja muzike." In Ovde Radio Beograd. Zbornik povodom pedesetogodišnjice, edited by Milan Bulatović et al., 103-129. Belgrade: Radio Beograd, 1979. [Orig. in Serbian Cyrillic]

Marković, Radivoje. "Prve godine.” In Ovde Radio Beograd. Zbornik povodom pedesetogodišnjice, edited by Milan Bulatović et al., 11-29. Belgrade: Radio Beograd, 1979. [Orig. in Serbian Cyrillic]

Miletić, Gojko. "Međunarodna afirmacija Narodnog pozorišta." In Jedan vek Narodnog pozorišta u Beogradu 1868-1968, edited by Milan Đoković, 554-571. Belgrade: Narodno pozorište, Nolit, 1968. [Orig. in Serbian Cyrillic]

Milojević, Milan. Anglo-Yugoslav Cultural Relations. London: s.n, 1944.

Mosusova, Nadežda. "Mesto Stevana Hristića u jugoslovenskoj i evropskoj muzici." In Život $i$ delo Stevana Hristića: zbornik radova sa naučnog skupa održanog 19. i 20. novembra 1985. povodom 100-godišnjice kompozitorovog rođenja, edited by Dimitrije Stefanović, 1-7. Belgrade: SANU, 1991. [Orig. in Serbian Cyrillic]

Mosusova, Nadežda. "Srpska muzička scena (125 godina Narodnog pozorišta)." In Srpska muzička scena. Zbornik radova sa naučnog skupa održanog od 15. do 18. decembra 1993. 
godine povodom 125-godišnjice Narodnog pozorišta, edited by Ana Matović, Nadežda Mosusova, Ranko Ivančević, 5-37. Belgrade: Muzikološki institut SANU, 1995. [Orig. in Serbian Cyrillic]

Nenezić, Zoran D. Masoni u Jugoslaviji 1764-1980. Belgrade: Narodna knjiga, 1984.

Pavlović, Mirka. "Veličina iz Beograda Bahrija Nuri Hadžić (1904-1993).” In 125 godina Narodnog pozorišta u Beogradu. Zbornik radova sa naučnog skupa održanog 16-19. novembra 1994, edited by Stanojlo Rajičić, 417-437. Belgrade: SANU, 1997. [Orig. in Serbian Cyrillic]

Pejović, Roksanda. Opera i balet Narodnog pozorišta u Beogradu (1882-1941). Belgrade, 1996. [Orig. in Serbian Cyrillic]

Radovanović, Aleksandar. Pregled istorije Narodnog pozorišta u Beogradu 1868-1993. Belgrade: Narodno pozorište, Institut za književnost i umetnost, 1994.
Švarc, Rikard. "Muzika u zemlji. Beograd. (Orguljski concert Jurija Arbatskog. Amaterski orkestar Lira. Jevrejsko vokalno udruženje Hanigun. Glasbena matica iz Ljubljane)." Zvuk 6 (1934): 233-234.

Švarc, Rikard. "Muzika u zemlji." Zvuk 8-9 (1935): 319-321.

Vasić, Aleksandar. "Muzički kritičar Rikard Švarc." Zbornik Matice srpske za scenske umetnosti i muziku 61 (2019): 87-103. [Orig. in Serbian Cyrillic]

Vinaver, Stanislav. "Muzički život." Misao 5-6 (1921): 416-424. [Orig. in Serbian Cyrillic]

Vučetić-Mladenović, Radina. Evropa na Kalemegdanu: "Cvijeta Zuzorić" i kulturni život Beograda 1918-1941. Belgrade: Institut za noviju istoriju Srbije, 2003. [Orig. in Serbian Cyrillic] 



\title{
Allies in Music: French influence and role models in the Cvijeta Zuzorić Association of Friends of Art
}

\author{
Srđan Atanasovski
}

In the interwar period, France was seen as the main military and diplomatic ally of the Kingdom of Serbs, Croats and Slovenes (SCS), later Kingdom of Yugoslavia, and the defender of the fragile Versailles Peace Treaty. This relationship resulted in a clear French influence in the realm of art and culture in Yugoslavia. Moreover, the triumph of the French cultural influence was also interpreted in the light of the simmering conflict between Serbian and Croat elites in Yugoslavia, as Serbian intellectuals traditionally gravitated toward Paris and France, unlike the Croat (and Slovene) ones, which had been part of the Central European and Austro-Hungarian cultural sphere. This article analyzes the French cultural influence through the musical activities of the Cvijeta Zuzorić Association of Friends of Art. The organization was established to promote modern art and the endeavors of young artists. It was firmly latched onto various mechanisms of state support, and participated in promoting the dominant ideology of the Karađorđević royal dynasty. The paper follows the association's musical activates through its three phases: the initial period, marked by annual artistic soirees, the middle period and the activities of the Narodni konzervatorijum (National Conservatory), which included weekly concerts of varying quality, and the final period of open music competitions. The article maps a clear picture of French artistic influences, which notably included open modeling of certain commissioned and awarded compositions on famous French pieces.

\section{France as an ally in politics and culture}

Throughout the interwar existence of Kingdom of SCS/Yugoslavia, the state was riven with internal political struggles and external European geopolitical instabilities. ${ }^{1}$ Born out of the WWI and the military victory of the allies and the Serbian army, the Kingdom of SCS was hastily proclaimed on December 1, 1918, at the official meeting between a delegation of the National Council of the State of Slovenes, Croats and

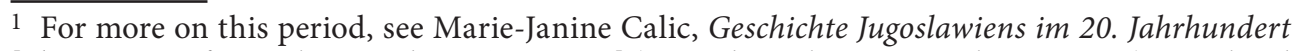
[The History of Yugoslavia in the $20^{\text {th }}$ Century] (Munich: Verlag C. H. Beck oHG, 2010), translated into Serbian as Mari-Žanin Čalić, Istorija Jugoslavije u 20. veku (Belgrade: Clio, 2013), 103-119. 
Serbs, formed on the southern Slavic territories of the defeated Austria-Hungary, and regent Alexander Karađorđević, representing the Kingdom of Serbia and its King Peter I. The newly formed Kingdom of SCS participated at the Paris Peace Conference in the following year, affirming its position as one of the main actors in the Balkans and securing its territory to clear dissatisfaction of many of its powerful neighbors, including Italy, Austria and Hungary. However, the kingdom's internal disputes were not resolved in Pairs, and continued well into the interwar period, even after the process of adopting a constitution was completed in 1921. These disputes can be summarized in three main, significantly overlapping issues - national, federal and dynastical - and the dividing lines were most strongly pronounced between the Serbian and Croatian political and economic elites. The main question, which can be felt throughout the interwar Yugoslav political landscape, is whether Serbs, Croats and Slovenes are three separate nations joining in a political union, or merely "tribes" of a single "integral" Yugoslav nation (hence integral Yugoslavism). ${ }^{2}$ Bearing in mind that the European interwar period was formative for the doctrine of nation-state sovereignty and dominated by primordial and racial interpretations of the nation, the importance of this question cannot easily be overemphasized. This issue is closely followed by deliberation on the internal governance of the kingdom, with the dilemma between a centralized system and a federal framework, where the separate nations would govern their respective historical or ethnic territories. Finally, a significant share of Croatian politicians contested the position of the Serbian royal dynasty, and demanded a discussion on the possibility of establishing a republican rule.

The resulting political turbulences-including political assassinations, terrorist actions, a period of dictatorship, federal restructuring, etc.- did not, however, take place in a vacuum, but in a context of perpetual contestation of the Versailles Treaty throughout the interwar period in Europe. The diplomatic alliances that Yugoslavia formed in the interwar period were thus reflected in the sphere of tempestuous internal politics. Overall, France was seen as the principal guardian of the Versailles Treaty, which countries like Germany, Italy and Hungary tried to subject to revision. The alliance with France, as well as other alliances supported by France, such as the Little Entente (with Czechoslovakia and Romania), were a major centripetal force in Yugoslav politics. Moreover, the French cultural and artistic influence immediately after the WWI was seen as a direct result of this fruitful alliance, since a significant part of artists and intellectuals had spent the war years in Paris. Therefore, the cultural influences of France throughout the interwar period were seen as an expression of friendship with a powerful protector. ${ }^{3}$

2 Cf. Jovo Bakić, Ideologije jugoslovenstva između srpskog i hrvatskog nacionalizma 1918-1941: sociološko-istorijska studija [The Ideologies of Yugoslavism between Serbian and Croatian Nationalism 1918-1941: A Sociological-Historical Study] (Zrenjanin: Gradska narodna biblioteka “Žarko Zrenjanin,” 2004).

3 Ljubodrag Dimić, Kulturna politika u Kraljevini Jugoslaviji: 1918-1941 [Cultural Policies in the Kingdom of Yugoslavia] (Belgrade: Stubovi kulture, 1997), Vol. 3, 186-187. 
The French influence was also interpreted in the context of the internal political divisions as a country amicable to the Serbian intelligentsia, as well as its political and economic elite. Besides France being the main military ally of the Serbian forces during the war, Serbian intelligentsia gravitated to France and Paris as a place of education, and was imbued by French cultural and artistic models, unlike their Croat and Slovene counterparts, who-as former citizens of AustriaHungary-were drawn toward the cultural centers of the German-speaking Central Europe. ${ }^{4}$ As Ljubodrag Dimić argues, the promotion of the French avant-garde and impressionism in painting was directly opposed to the academicism permeating the Viennese and Munich schools. ${ }^{5}$

\section{The Cvijeta Zuzorić Association of Friends of Art}

The Cvijeta Zuzorić Association of Friends of Art (Udruženje prijatelja umetnosti Cvijeta Zuzorić) was established in Belgrade in 1922 on the incentive of Branislav Nušić, a prominent Serbian writer and head of the Arts Department at the Ministry of Education. ${ }^{6}$ The task of the association was to draw public attention to the local artistic production, and especially attract the Belgrade middle and upper classes to support high art. ${ }^{7}$ The founders aspired to encourage interest in art and "create the conditions for its progress and development among our people." 8 The idea was for the Cvijeta Zuzorić Association to be run by the wives of prominent Belgrade politicians, which would bring considerable social capital and draw sponsorship for modern art from the Belgrade financial elite, including the royal family. However, this arrangement also resulted in strong and unambiguous influence of state cultural policies throughout the association's existence, which seems to have been particularly pronounced in its musical activities. ${ }^{9}$ For example, the association

\footnotetext{
4 See Milosav Janićijević, Stvaralačka inteligencija međuratne Jugoslavije [The Creative Intelligentsia of Interwar Yugoslavia] (Belgrade: Institut društvenih nauka, Centar za sociološka istraživanja, 1984), 100-112.

5 Dimić, Kulturna politika, 190.

6 For details on the Cvijeta Zuzorić Association, see Radina Vučetić, Evropa na Kalemegdanu. "Cvijeta Zuzorić" i kulturni život Beograda 1918-1941 [Europe in Kalemegdan. "Cvijeta Zuzorić" and the Belgrade Cultural Life] (Belgrade: Institut za noviju istoriju Srbije, 2003).

7 Cf. Peđa J. Marković, Beograd i Evropa 1918-1941. Evropski uticaji na proces modernizacije Beograda [Belgrade and Europe 1918-1941. European influences on the process of Belgrade's modernization] (Belgrade: Savremena administracija, 1992), 179.

8 Historical Archive of the City of Belgrade [Istorijski arhiv Beograda (IAB)], Cvijeta Zuzorić Association of Friends of Art [Udruženje prijatelja umetnosti Cvijeta Zuzorić (CZ)], 3a.

9 Cf. Ivana Vesić, Konstruisanje srpske muzičke tradicije u periodu između dva svetska rata [Constructing the Serbian Musical Tradition in the Period between the Two World Wars] (Belgrade: Muzikološki institut SANU, 2018), 23, 110-123; Srđan Atanasovski, "Muzička delatnost Udruženja prijatelja umetnosti Cvijeta Zuzorić u kontekstu kulturne politike Kraljevine Jugoslavije [The
} 
regularly organized events promoting a shared Yugoslav and pan-Slavic identity and fostering cultural ties within the country, as well as events that were in accordance with the kingdom's foreign policy.

With respect to its musical activities, the history of the association can be divided into three periods: the first one covers the initial period dominated by artistic charity soirées, the second encompasses the activities of the National Conservatory launched in 1925 and maintained until 1932, and the third period includes open competitions for new Yugoslav musical compositions, organized between 1934 and 1941. The first period is characterized by irregular musical activity and frequent cooperation with the literary and visual arts section of the association. Musical performances were thus often held as part of artistic soirées, matinées or exhibitions. The association's pronounced openness and proclivity toward modernism in art was clearly established in these initial activities, and one of the flagship events in this period was the artistic soirée entitled Hiljadu i druga noć (The Thousand and Second Night), fashioned after surrealist avant-garde soirées held in Paris.

The society launched the National Conservatory in 1925 as a regular series of concerts meant to enrich the musical life in the capital. The concerts usually took place twice per month, they varied in content and quality, and often had educational purposes. As the quality started declining (especially after 1929), and the Belgrade musical life became richer, the management felt this was not the real purpose of the organization, and closed National Conservatory with the 1932 season. The music section of the association opted to organize funding competitions for new Yugoslav compositions on an annual basis as a better way of fostering modern music production by young composers. In the period between 1934 and 1941, they conducted five competitions, awarding monetary prizes to the best compositions submitted, and holding concerts of laureates' pieces, styled as festivals of Yugoslav music. The inaugural competition of 1934-1935 was open for new symphonic pieces. In 1936 and 1940, they invited composers to submit chamber music. In 1938, they held an opera competition. And the final edition in 1941 awarded the best new Yugoslav art songs. The association remained active until German occupation in 1941, when it decided to close its doors, to the resentment of the occupying forces.

Modeling after eccentrism:

Satie's Parade and Milojevićs Sobareva metla

Of all the musical works premiered or created at the instigation of the Cvijeta Zuzorić Association of Friends of Art, the ballet Sobareva metla / Le balai du valet

musical activity of the Cvijeta Zuzoric Association of Friends of Art in the context of the cultural policy of the Kingdom of Yugoslavia]," in Likovi i lica muzike, edited by Ivana Perković-Radak, Tijana Popović-Mlađenović (Belgrade: Fakultet muzičke umetnosti, 2010), 207-224. 
(The Servant's Besom) by Miloje Milojević (to a libretto by poet Marko Ristić, and with Klaudija Isačenko and Jelena Poljakova as the original choreographers) has been attracting the greatest attention of music scholars for decades. This ballet indeed represents a sort of excursion both in the oeuvre of Milojević himself as well as the musical landscape of interwar Belgrade in general. Music scholars have analyzed the progressive, avant-garde style used by Milojević, emphasizing particularly the collage structure of the music, polystylism, use of non-musical sound elements (such as a gunshot) and musical references ranging from Richard Wagner to popular music, which all serve to draw clear parallels to the ballet Parade by Eric Satie and Jean Cocteau, produced by Sergei Diaghilev's company Ballets Russes in Paris in 1917. ${ }^{10}$

The political and social frictions immediately after the WWI created the specific cultural and artistic landscape that this work is inextricably linked to. Writer and literary critic Milan Bogdanović used the term "post-war modernism" at that time, and it may serve well to explain this phenomenon. Bogdanović notes that "after the war modernism has all been in a certain state of exaltation, in ecstasy, a delirium. It is not reformist, but wants to be destructive, which has given it the apparent character of a revolutionary literary event." 11 The end of the war and the final realization of the national idea of liberation and unification also served as a significant impetus for the development of modernist orientations. In the years immediately following the war, Belgrade was ruled by a kind of "explosion of novelties" in virtually all segments of city life, especially in the field of education, culture and art. ${ }^{12}$ With the final "vindication of Kosovo," the national myths became redundant as the basic inspiration of artists, who were seemingly free to reject collectivist, national paradigms and turn to

\footnotetext{
${ }^{10}$ See Marija Masnikosa, "Funkcija muzičkih simbola u kompozicijama Smrt majke Jugovića i Sobareva metla Miloja Milojevića" [The function of musical symbols in the compositions Smrt majke Jugovića and Sobareva metla by Miloje Milojević], in Izuzetnost i sapostojanje, edited by Miško Šuvaković (Belgrade: Fakultet muzičke umetnosti, 1997), 140-145; Biljana Milanović, "Sobareva metla: bliskost s evropskom avangardom [Sobareva metla: closeness to the European avant-garde]," in Kompozitorsko stvaralaštvo Miloja Milojevića, edited by Melita Milin, Vlastimir Peričić (Belgrade: Muzikološki institut SANU, 1998), 262-277; Jelena Arnautović, "Korak ispred vremena: dijalog Miloja Milojevića sa francuskim neoklasicizmom u baletu Sobareva metla [One step ahead of time: Miloje Milojevićs dialogue with French neoclassicism in the ballet Sobareva metla]," in Tradicija kao inspiracija, edited by Sonja Marinković, Sanda Dodik (Banja Luka: Akademija umjetnosti, 2010), 72-86.

${ }^{11}$ Milan Bogdanović, "Slom posleratnog modernizma [The collapse of post-war modernism]," Danas 3 (1934): 300-311.

12 Katarina Tomašević, "Prividni ili stvarni sukob Starog i Novog (vidovi sapostojanja tradicionalnog i modernog u srpskoj muzici između dva svetska rata) [Apparent or real conflict between the Old and the New (the types of coexistence of the traditional and the modern in Serbian music between the two World Wars)]," in Izuzetnost i sapostojanje, edited by Miško Šuvaković, 103-104; cf. Katarina Tomašević, Na raskršću Istoka i Zapada. O dijalogu tradicionalnog i modernog u srpskoj muzici (1918-1941) [At the crossroads between the East and West. On the dialogue of the traditional and the modern in Serbian music] (Belgrade, Novi Sad: Muzikološki institut SANU, Matica srpska, 2009).
} 
the "art for art's sake" poetics. ${ }^{13}$ Post-war modernism also represented the aspirations of artists to secure appropriate recognition and place in the society for their art, as there was a general aspiration within the ruling class and elites in post-war Belgrade to revive the cultural life and professionalize artistic fields. ${ }^{14}$

Encouraging modernism could also have been an important tool of cultural policy in the hands of the regime, with the aim of homogenizing and denationalizing the cultural and artistic scene in the spirit of integral Yugoslavism. As already discussed, immediately after the war and still in the process of constituting a common state, the ideology of Yugoslavism was perpetually challenged. As Branka Prpa concludes, even in the ranks of the Serbian intelligentsia, especially in the Belgrade circles, and as early as around 1923, there was strong skepticism about the idea of Yugoslav unity. ${ }^{15}$

Articulating a demand to be included in the currents of European culture and art, the proponents of modernistic tendencies often made clear statements by adopting the most avant-garde acts of their European contemporaries as their role models. Not surprisingly, this was prone to ridicule. In the words of painter Radoje Marković from the mid-1920s: "In our country, the intellectual leadership was inspired by ready-made ideas from other environments." 16 Vasa Pomorišac also commented that "our artists took, without consideration, everything that the West, i.e. Paris, declared modern." 17 The origin of these models and "readymade ideas," however, was not accidental-they were overwhelmingly of French provenance. Thus, for example, the Dadaist/Surrealist literary movement (writers such as Aleksandar Vučo, Milan Dedinac, Marko Ristić, etc.) was completely under the French influence and closely followed the developments in Paris. ${ }^{18}$ Miloje Milojević also spent the WWI in Paris in direct contact with the newest achievements in French music. ${ }^{19}$

The annual artistic soirées were a mechanism through which the Cvijeta Zuzorić Association positioned itself on the cultural scene of the capital and collected the first significant financial resources for the construction of its Art Pavilion.

\footnotetext{
${ }^{13}$ Branka Prpa-Jovanović, "Jugoslavija kao moderna država u viđenjima srpskih intelektualaca 1918-1929" [Yugoslavia as a modern state in the views of Serbian intellectuals 1918-1929] (PhD diss., Univerzitet u Beogradu, 1995), 423; cf. Branka Prpa, Srpski intelektualci i Jugoslavija: 1918-1929 [Serbian Intellectuals and Yugoslavia: 1918-1929] (Belgrade: Clio, 2018).

14 Jelena Milojković-Đurić, "Muzika kao deo srpske kulture u periodu između dva svetska rata [Music as a part of Serbian culture in the period between the two World Wars]," (PhD diss., Univerzitet u Beogradu, 1980), 16-17.

15 Prpa-Jovanović, “Jugoslavija kao moderna država," 93. Cf. Bakić, Ideologije jugoslovenstva.

16 Prpa-Jovanović, "Jugoslavija kao moderna država," 378-379.

17 Milojković-Đurić, "Muzika kao deo srpske kulture," 195.

18 Prpa-Jovanović, "Jugoslavija kao moderna država," 172.

${ }^{19}$ See Petar Konjović, Miloje Milojević: kompozitor i muzički pisac [Miloje Milojević: Composer and Music Writer] (Belgrade: Srpska akademija nauka, 1954), 58-63.
} 
In addition to the first and most cited ball, The Thousand and Second Night, for which Milojević composed his ballet Sobareva metla and which is the only one documented in the archival records of the association, two more balls were held: Svadba u Skadarliji (A Wedding in Skadarlija) and Zlatni vek (The Golden Age). ${ }^{20}$ The Thousand and Second Night ball was organized on February 16, 1923, at a time when the administration of the Cvijeta Zuzorić Association was not yet operative and the organization was in the hands of Branislav Nušić, who worked in the Arts Department of the Ministry of Education. The idea for the event came from Rade Drainac, who witnessed the success of an art ball in Zagreb, and suggested that the ball be organized for the benefit of artists and writers. In consultation with Nušić and "several artists, writers and friends," the original idea was changed so that the funds raised would go for the construction of the Art Pavilion and the artists who took part received appropriate fees. Artists were paid 46,950 dinars (Milojević received 1,000 dinars), and 80,288 dinars were raised for the pavilion. ${ }^{21}$

Nušić invited an extremely large number of artists to the initial meetings for planning the ball-as many as 77-among whom were representatives of the most important institutions (such as the National Theatre), art schools, the press and several ministers. ${ }^{22}$ Notes from the meeting are preserved in the archives and include numerous suggestions regarding the contents of the soirée. Although most of these proposals were rejected, we can make certain conclusions about how the final content of the ball was shaped. The proposals most often imitated the avant-garde experiments of the Parisian art scene-one can find mentions of caricatures, imitations of cinema, etc. It is in these pages that we find the inception of the ballet Sobareva metla, which is mentioned for the first time as an "eccentric ballet of Ms. Isačenko". It is obvious that some of those present had information on Satie and Cocteau's ballet Parade, as one page of the notes has the following list jotted down: "7 record players, one typewriter, one siren-one Singer sewing machine-drum [...] saw, ocarina" 23 (see Figure 1). In other words, most of the non-musical sounds present in Satie and Cocteau's Parade were mentioned in the notes from this meeting. Thus, the connection between Sobareva metla and Parade, which these notes make clear, seems to have been conceived within the framework of joint artistic meetings. Besides describing the ballet as "eccentric," the notes also envisage the music to be composed as "futuristic." 24

\footnotetext{
${ }^{20}$ Krista Đorđević, “Osnivanje i delatnost Udruženja prijatelja umetnosti 'Cvijeta Zuzorić”" [The establishment and activities of the Cvijeta Zuzorić Association of Friends of Art], in Beograd u sećanjima: 1919-1929 (Belgrade: Srpska književna zadruga, 1980), 77.

${ }^{21} \mathrm{IAB}, \mathrm{CZ}, 4,4 \mathrm{j}$.

${ }^{22} \mathrm{IAB}, \mathrm{CZ}, 4 \mathrm{a}$.

23 “7 gramofona, jedna pisaća mašina, jedna sirena - jedna singerova šivaća mašina - bubanj [...] testeraš, okarina."

${ }^{24} \mathrm{IAB}, \mathrm{CZ}, 4$.
} 


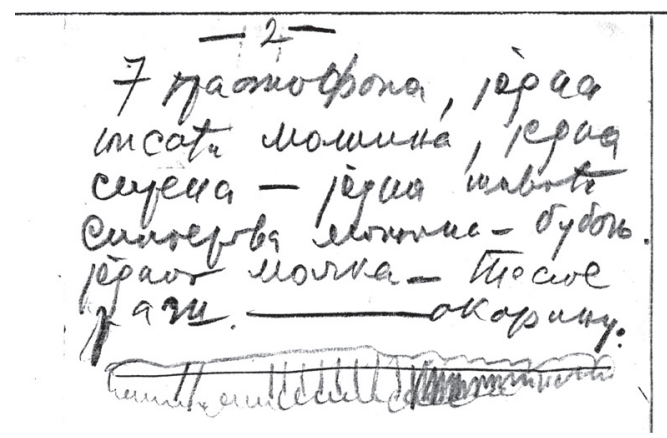

Figure 1. Fragment of the notes from the preparation of The Thousand and Second Night ball. IAB, CZ, 4 .

The notes from the artistic meetings in preparation of the soirée lead us to conclude that the avant-garde, collage structure of the ballet Sobareva metla is not merely Milojevićs intention, but a result of a kind of collective authorship. Belgrade's surrealist writers probably have the most credit for the avant-garde result itself, as this orientation was much more pronounced in their works than in those of contemporary Belgrade composers (of whom only Stanislav Binički and Milojević attended the meetings). If the poetics and concept of this ballet did not originate with Milojević, there is also little merit in interpreting this work as "a testimony to the early aspirations for experiment in Serbian music." ${ }^{25}$ On the contrary, it is a one-time influence, facilitated at a very specific sociopolitical moment, of avant-garde tendencies that were evolving in the contemporary literary field, and not a development within the field of music itself. Finally, The Thousand and Second Night ball in its entirety can be interpreted as an aspiration of the Belgrade political and artistic elite to present the achievements of the French avant-garde to the general public in Belgrade.

The artistic soirée raised great interest and was highly attended; the hall of Hotel Kasina, where it was held, was full and a provisional hallway was set up to connect it to the hall of Hotel Pariz next door to gain more space. ${ }^{26}$ The ball was of great importance for the initial positioning of the Cvijeta Zuzorić Association as an institution promoting modernist aspirations. However, it is also certain that the strong and broad official and institutional support, including from the National Theater and the Ministry of Education, somewhat blunted the edge of the avant-garde in the performances and reduced them to a kind of "cultured artistic event," in the words of Mirjana Veselinović-Hofman. ${ }^{27}$ The Thousand and Second Night ball was a distinct event for the interwar Belgrade society, in which

\footnotetext{
25 Milanović, “Sobareva metla," 262.

26 Đorđević, “Osnivanje i delatnost," 77.

${ }^{27}$ Mirjana Veselinović-Hofman, “Teze za reinterpretaciju jugoslovenske muzičke avangarde [Theses for the reinterpretation of the Yugoslav musical avant-garde]," Muzički talas 30-31 (2002): 25.
} 
avant-garde artistic practices-otherwise related primarily to poetry, as well as certain individual artists-were briefly institutionalized. ${ }^{28}$ It is within one such event, and owing to the sociopolitical conditions, that the unique transfer of postwar modernism to the field of music was achieved, which is indeed an extraordinary feat if we consider the demanding material conditions of musical production. ${ }^{29}$

\section{Modeling after impressionism: \\ Debussy, Milojevićs Plave legende and Bradićs String Trio}

As early as around 1925, we can notice a reaction to the avant-garde experiments, which were on the one side accused of being hermetic, overly intellectual and inaccessible, and on the other perceived as excessively emphatic, emotional and expressive. ${ }^{30}$ At the same time, the overall activities of Cvijeta Zuzoric Association of Friends of Art from 1923 to the end of the 1930s continued to be strongly marked by French cultural influence, in accordance with the cultural policy of the Kingdom of SCS/Yugoslavia. Thus, an exhibition of French graphics of the $17^{\text {th }}$ and $18^{\text {th }}$ centuries was held in 1926 in cooperation with the French-Serbian Club, which a letter to the Ministry of Education said was "organized for the purpose of French propaganda." ${ }^{11}$ The association then arranged an exhibition of French modern painters, in which "the best Parisian modern masters are to participate," and received 2,000 dinars from the ministry for this project. ${ }^{32}$

In the musical activities of the association, the French influence was manifested on the one hand in the French repertoire, and on the other hand in the first performances of works by Yugoslav authors written in the French manner. At the aforementioned exhibition in the hall of the French-Serbian Club, the association organized a matinée of $18^{\text {th }}$-century French art on March 8, 1926, which included performances of music by Jean-Baptiste Lully and Jean-Philippe Rameau. The programs of the association's musical events, including the activities of the National Conservatory, featured works by French composers such as Ernest Chausson, Camille Saint-Saëns, Vincent d'Indy, Claude Debussy, Philippe Gaubert and Gabriel Fauré. As we can see, "the French manner" no longer implied "eccentric" avant-garde experiments, as in case of The Thousand and Second Night ball, but above all what was seen as impressionism in music. Miloje Milojević, who was

\footnotetext{
${ }^{28}$ Cf. Bogdanović, "Slom posleratnog modernizma," 301.

${ }^{29}$ In this regard, it is also important to note that Milojević's ballet premiered from a piano score reduction, and that the work was only published in full as late as 1981.

${ }^{30}$ Prpa-Jovanović, "Jugoslavija kao moderna država," 170.

${ }^{31}$ Archives of Yugoslavia [Arhiv Jugoslavije (AJ)], Ministry of Education of the Kingdom of Yugoslavia [Ministarstvo prosvete Kraljevine Jugoslavije], 66-626-1034, Letter to the Ministry of Education for the purpose of obtaining customs relief, March 13, 1926.

32 AJ, 66-626-1034, Letter of president Olga Stanojević to the Ministry of Education, August 7, 1926.
} 
also one of the leading music writers of the period, explicitly voiced this position in his essay on impressionism, describing this style as quintessentially French, and noting that musical impressionism is an art that originates "on the French soil." 33

It is not suspiring that some of the most paradigmatic works of impressionism in Serbian music history were composed in direct connection to the Cvijeta Zuzorić Association of Friends of Art. ${ }^{34}$ The turn toward impressionism is probably best exemplified in the oeuvre of Milojević himself: just one year after Sobareva metla, Milojević presented his cycle Plave legende (Blue legends), op. 34, for piano and reciter, set to two poems by Jovan Dučić. The piece was performed for the first time at the concert of contemporary authors on February 17, 1924, and again at the concert of contemporary Yugoslav composers on March 17, 1926, both organized by the Cvijeta Zuzorić Association. ${ }^{35}$ Plave legende, subtitled as "poetic prose with piano accompaniment" (pesnička proza uz pratnju klavira), is characterized in musicological literature as completely and unambiguously Debussyan:

What dazzles in Milojevićs Plave legende is Debussyism, but Debussyism so complete and unambiguous that listening to the piece one could think that he or she is attending a performance of an unknown and newly discovered work by the French master. ${ }^{36}$

Dučić, a poet of a typically pro-French orientation, provided verses for another musical work related to the Cvijeta Zuzorić Association: Dubrovački rekvijem (The Dubrovnik Requiem) for mixed choir and soprano solo by Stevan Hristić, which was composed specifically for the occasion of the opening of the association's Art Pavilion on December 23, 1928. ${ }^{37}$ Once again, this work is recognized as an example of impressionism in Serbian music. ${ }^{38}$

However, the most open reference to French impressionism and Debussy, who already epitomized the style, was reached in the last phase of the association's musical

\footnotetext{
${ }^{33}$ Miloje Milojević, Muzičke studije i članci [Musical Studies and Articles], Vol. 3, edited by Gordana Trajković-Milojević (Belgrade: Izdavačka knjižarnica Gece Kona, 1953), 167.

${ }^{34}$ For a discussion on what constitutes and represents impressionism in Serbian music, see Valentina Radoman, Muzički impresionizam: elementi impresionističkog stila u srpskoj muzici prve polovine 20. veka [Musical Impressionism: Elements of the Impressionist Style in Serbian Music of the First Half of the $20^{\text {th }}$ Century] (Novi Sad: Akademija umetnosti, 2018), 96-146.

${ }^{35} \mathrm{IAB}, \mathrm{CZ}, 756,770$.

${ }^{36}$ Vlastimir Trajković, "Ključni opusi u stvaralaštvu Miloja Milojevića [Key opuses in the work of Miloje Milojević]," in Kompozitorsko stvaralaštvo Miloja Milojevića, edited by Melita Milin, Vlastimir Peričić (Belgrade: Muzikološki institut SANU, 1998), 21-22. The information dating Plave legende to 1927 in the same source obviously cannot be accurate.

${ }^{37}$ IAB, CZ, 43.

${ }^{38}$ Tijana Popović, "Elementi impresionističkog stila u stvaralaštvu Stevana Hristića [Elements of the impressionist style in the work of Stevan Hristić]," in Stevan Hristić i njegovo delo, edited by Vlastimir Peričić (Belgrade: Fakultet muzičke umetnosti, 1985), 42-69.
} 
activities, namely in its competitions for new Yugoslav compositions, and it was a work by a composer from Zagreb, Zvonimir Bradić, born in 1904 and a student of Blagoje Bersa. Responding to the second edition of the competition (1935), calling for new chamber music, Bradić submitted an elaborate and interpretatively demanding three-movement String Trio, the score of which has been preserved in the archive of the society. The jury consisted of three association members-Divna Popović, Nela Alkala and Mica Simić-and three composers from the music section of the association-Mihailo Vukdragović, Rikard Švarc and Kosta P. Manojlović. Selected from 28 submissions, Bradićs trio was awarded first prize, followed in second place by Antun Dobronićs Ballad for cello and piano and Mihovil Logar's song cycle Legenda $o$ Marku (The Legend of Marko). The jury did not provide an explanation for the decision in writing, but Manojlović and Vukdragović published an announcement for a concert of the awarded pieces, which was held on May 7, 1936:

Mr. Bradic's String Trio consists of three movements and confronts the performers with a difficult problem. The work is purely tonal and thematically elaborated, with freer harmonic progressions, impulsive rhythm and use of chromatics both in the theme and in harmony. In this respect, the theme $A$ from the first and second movements stands out. ${ }^{39}$

While using much more laudatory language to describe Logar's song cycle, Manojlović seems curiously reserved in praise of the winner of the competition. Similarly, Vukdragović provided only biographical data on Bradić in his announcement, adding that he would act as an "excellent representative of a solid composition school" established by Bersa, while delving into specific merits of Dobronićs and Logar's works. This wavering attitudes might stem from the fact that the jury judged the submitted works from the score, while the announcements were written when the performers were already ahead with their rehearsals. Music critics who attended the concert-Branko Dragutinović and Milenko Živković-were even more reserved toward Bradićs String Trio:

What catches the eye most in Zvonimir Bradic's String Trio is the agility in his treatment of instruments-a trait he obviously took from the excellent school of the late Blagoje Bersa. Apart from this, the lack of invention, the harmony that reaches a harsh hardness in his abandoning of all considerations of tonality, the tendency to expand the formal frameworks, leading to a dissolution of form-all of this results in Bradic's trio leaving a rather vague impression, despite some successful moments (especially the fugato at the beginning of the third movement). (B.D. $)^{40}$

\footnotetext{
$39 \mathrm{IAB}, \mathrm{CZ}, 785$.
}

40 Ibid. 
The String Trio of Z. Bradic lacks strong thematic invention; if those endless repetitions were omitted in a formal sense, this composition could act more directly. In our opinion, the second movement is formally the most compact. Surprisingly, the cello part is insufficiently developed throughout the trio. (M.Ž. ${ }^{41}$

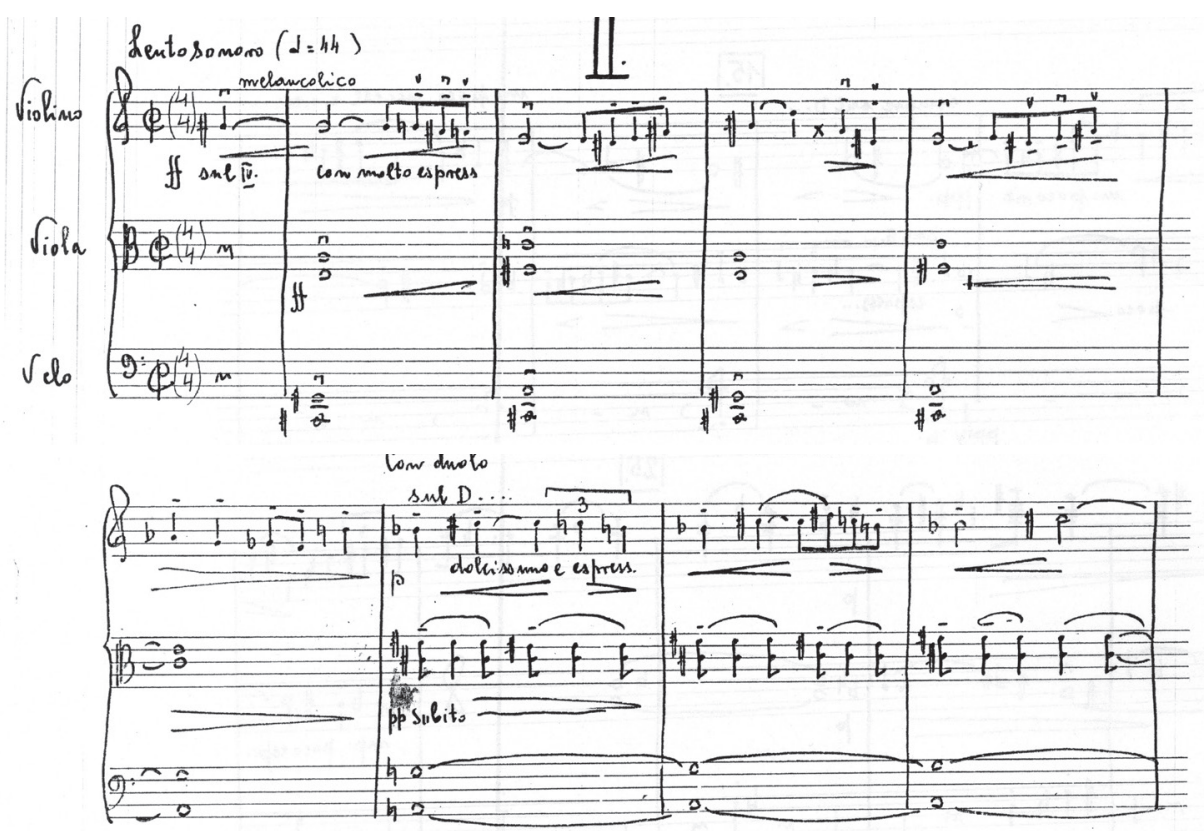

Figure 2. Zvonimir Bradić, String trio, $2^{\text {nd }}$ movement, Lento sonoro, m. 1-10. IAB, CZ, 785.

Très modéré

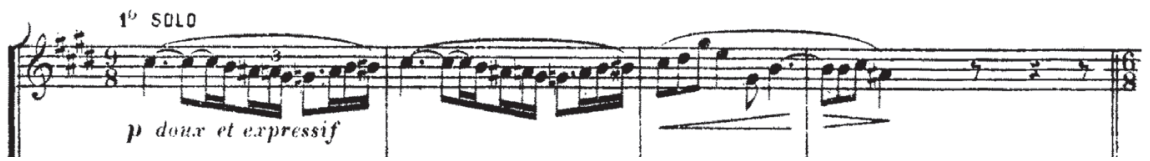

Figure 3. Claude Debussy, Prélude à l'après-midi d’un faune

(Paris: E. Fromont, 1895), flute part, m. 1-4.

${ }^{41}$ Ibid. 
In other words, there is a stark contrast between the laudatory first prize on one hand and the reserved statements by the jury members and mixed reviews by music critics on the other. This contrast might partially be explained by the score itself-it was the sole basis for the work of the jury. Surprisingly, the very beginning of the lyrical second movement, Lento sonoro, contains a direct citation of one of the most emblematic themes of musical impressionism: the opening of Claude Debussy's Prélude à l'après-midi d'un faune (1894). What could have served as a signal of political suitability of this chamber work is then used as the first subject of the lyrical Lento and the basis for thematic development (see Figure 2 and 3).

Based on the discussed cases, it is clear that the musical activities of the Cvijeta Zuzoric Association of Friends of Art strongly represented the official pro-French cultural policies of the Kingdom of Yugoslavia, at least up to mid-1930s, when the influence of France itself started to waiver and Yugoslavia was forced to reposition itself on the map of European alliances. There are, however, two important points which need to be additionally emphasized, and which are also important for understanding the broader musical scene of interwar Yugoslavia. Firstly, it is consequential to note that what we might interpret as influences of French music were-in the most prominent cases, such as Milojevićs Sobareva metla and Plave legende and Bradićs String Trio-clear and unequivocal modeling and quotations that would have been accessible and understandable to the educated audience of the Cvijeta Zuzorić Association. Secondly, it is clear that the perception of what was "French" regressed during this period from avant-garde art to academic impressionism. This change comes from both sociopolitical and professional reasons: the specific circumstances that enabled the encroachment of post-war modernism into music were short-lived, and professionalization and consolidation of the field of music became a priority. ${ }^{42}$ In the context of the Cvijeta Zuzorić Association of Friends of Art, this resulted in a seeming rise of conservatism and academism, which even competitions for new compositions designed to promote modern music could not fully address. The cutting edge of French influences, which in 1923 were epitomized by the likes of Erik Satie, Jean Cocteau and Sergei Diaghilev, was blunted and reduced in only a few years to the former glory of Claude Debussy, already deeply ingrained in musical academism.

\footnotetext{
${ }^{42}$ Cf. Tomašević, Na raskršću Istoka i Zapada; Vesić, Konstruisanje srpske muzičke tradicije; Ivana Vesić, Vesna Peno, Između umetnosti i života: o delatnosti udruženja muzičara u Kraljevini SHS/ Jugoslaviji [Between art and Life: On the Activities of Musicians' Associations in the Kingdom of SCS/Yugoslavia] (Belgrade: Muzikološki institut SANU, 2017).
} 


\section{Primary sources:}

Historical Archive of the City of Belgrade (IAB) (Belgrade): Cvijeta Zuzorić Association of Friends of Art
Archives of Yugoslavia (AJ) (Belgrade): Ministry of Education of the Kingdom of Yugoslavia

\section{References:}

Arnautović, Jelena. "Korak ispred vremena: dijalog Miloja Milojevića sa francuskim neoklasicizmom u baletu Sobareva metla." In Tradicija kao inspiracija, edited by Sonja Marinković, Sanda Dodik, 72-86. Banja Luka: Akademija umjetnosti, 2010. [Orig. in Serbian Cyrillic]

Atanasovski, Srđan. "Muzička delatnost Udruženja prijatelja umetnosti Cvijeta Zuzorić u kontekstu kulturne politike Kraljevine Jugoslavije." In Likovi i lica muz$i k e$, edited by Ivana Perković-Radak, Tijana Popović-Mlađenović, 207-224. Belgrade: Fakultet muzičke umetnosti, 2010. [Orig. in Serbian Cyrillic]

Bakić, Jovo. Ideologije jugoslovenstva izmedu srpskog $i$ hrvatskog nacionalizma 1918-1941: sociološko-istorijska studija. Zrenjanin: Gradska narodna biblioteka “Žarko Zrenjanin”, 2004.

Bogdanović, Milan. "Slom posleratnog modernizma." Danas 3 (1934): 300-311.

Calic, Marie-Janine. Geschichte Jugoslawiens im 20. Jahrhundert. Munich: Verlag C. H. Beck oHG, 2010.

Čalić, Mari-Žanin. Istorija Jugoslavije u 20. veku. Translated by Ranka Gašić and Vladimir Babić. Belgrade: Clio, 2013. [Orig. in Serbian Cyrillic]

Dimić, Ljubodrag. Kulturna politika u Kraljevini Jugoslaviji: 1918-1941. Politika i stvaralaštvo. Belgrade: Stubovi kulture, 1997. [Orig. in Serbian Cyrillic]
Đorđević, Krista, "Osnivanje i delatnost Udruženja prijatelja umetnosti 'Cvijeta Zuzorić"' In Beograd u sećanjima: 19191929, 76-83. Belgrade: Srpska književna zadruga, 1980. [Orig. in Serbian Cyrillic]

Janićijević, Milosav. Stvaralačka inteligencija međuratne Jugoslavije. Belgrade: Institut društvenih nauka, Centar za sociološka istraživanja, 1984.

Konjović, Petar. Miloje Milojević: kompozitor i muzički pisac. Belgrade: Srpska akademija nauka, 1954. [Orig. in Serbian Cyrillic]

Marković, Peđa J. Beograd i Evropa 1918-1941. Evropski uticaji na proces modernizacije Beograda. Belgrade: Savremena administracija, 1992.

Masnikosa, Marija. "Funkcija muzičkih simbola u kompozicijama Smrt majke Jugovića i Sobareva metla Miloja Milojevića." In Izuzetnost $i$ sapostojanje: $V$ medunarodni simpozijum Folklor, muzika, delo, edited by Miško Šuvaković, 140-145. Belgrade: Fakultet muzičke umetnosti, 1997. [Orig. in Serbian Cyrillic]

Milanović, Biljana. "Sobareva metla: bliskost s evropskom avangardom." In Kompozitorsko stvaralaštvo Miloja Milojevića, edited by Melita Milin, Vlastimir Peričić, 262-277. Belgrade: Muzikološki institut SANU, 1998. [Orig. in Serbian Cyrillic]

Milojević, Miloje. Muzičkestudije i članci. Vol. 3, edited by Gordana Trajković-Milojević. 
Belgrade: Izdavačka knjižarnica Gece Kona, 1953. [Orig. in Serbian Cyrillic]

Milojković-Đurić, Jelena. "Muzika kao deo srpske kulture u periodu između dva svetska rata.", $\mathrm{PhD}$ diss., Univerzitet u Beogradu, 1980.

Popović, Tijana. "Elementi impresionističkog stila u stvaralaštvu Stevana Hristića." In Stevan Hristić i njegovo delo. edited by Vlastimir Peričić, 42-69. Belgrade: Fakultet muzičke umetnosti, 1985.

Prpa-Jovanović, Branka, "Jugoslavija kao moderna država u viđenjima srpskih intelektualaca 1918-1929." PhD diss., Univerzitet u Beogradu, 1995.

Prpa, Branka. Srpski intelektualci i Jugoslavija: 1918-1929. Belgrade: Clio, 2018.

Radoman, Valentina. Muzički impresionizam: elementi impresionističkog stila $u$ srpskoj muzici prve polovine 20. veka. Novi Sad: Akademija umetnosti, 2018.

Tomašević, Katarina. "Prividni ili stvarni sukob Starog i Novog (vidovi sapostojanja tradicionalnog i modernog u srpskoj muzici između dva svetska rata)." In Izuzetnost $i$ sapostojanje: $V$ međunarodni simpozijum Folklor, muzika, delo, edited by Miško Šuvaković, 103-104. Belgrade: Fakultet muzičke umetnosti, 1997. [Orig. in Serbian Cyrillic]
Tomašević, Katarina. Na raskršću Istoka i Zapada. O dijalogu tradicionalnog i modernog u srpskoj muzici (1918-1941). Belgrade, Novi Sad: Muzikološki institut SANU, Matica srpska, 2009. [Orig. in Serbian Cyrillic]

Trajković, Vlastimir. "Ključni opusi u stvaralaštvu Miloja Milojevića." In Kompozitorsko stvaralaštvo Miloja Milojevića, edited by Melita Milin, Vlastimir Peričić, 18-30. Belgrade: Muzikološki institut SANU, 1998. [Orig. in Serbian Cyrillic] Veselinović-Hofman, Mirjana. “Teze za reinterpretaciju jugoslovenske muzičke avangarde." Muzički talas 30-31 (2002): 18-32.

Vesić, Ivana. Konstruisanje srpske muzičke tradicije u periodu izmedu dva svetska rata. Belgrade: Muzikološki institut SANU, 2018. [Orig. in Serbian Cyrillic]

Vesić, Ivana, Peno, Vesna. Između umetnosti i života: o delatnosti udruženja muzičara u Kraljevini SHS/Jugoslaviji. Belgrade: Muzikološki institut SANU, 2017. [Orig. in Serbian Cyrillic]

Vučetić, Radina. Evropa na Kalemegdanu. "Cvijeta Zuzorić" i kulturni život Beograda 1918-1941. Belgrade: Institut za noviju istoriju Srbije, 2003. [Orig. in Serbian Cyrillic] 



\title{
7. \\ The echoes of diplomatic disputes. The Macedonian Question in the work of Serbian and Yugoslav music scholars
}

\author{
Ivana Vesić
}

As the Great Eastern Crisis was approaching in the mid-1870s, the conflicting political interests of neighboring Balkan peoples started to manifest. ${ }^{1}$ Claiming primacy over the same territory of the Ottoman Empire and its inhabitants in their mutually excluding national projects, political elites of the Balkans initiated longstanding political and diplomatic struggles that did not lose intensity over the course of time. The so-called Macedonian Question became one of the most important points of dispute between the countries of this part of Europe at the time, imposing itself as an almost insurmountable obstacle in the relations between Serbian and Bulgarian elites since the second half of the $19^{\text {th }}$ century. The end of the Second Balkan War (1913), and even more so the Great War with the Treaty of Neuilly between the Kingdom of Serbs, Croats and Slovenes (SCS) and the Kingdom of Bulgaria (1920) did not bring a stabilization of the political situation in the region. On the contrary, the fact that the territory of Vardar Macedonia was recognized as part of the newly founded Yugoslav Kingdom fueled fierce reactions of the Bulgarian side throughout the interwar period. ${ }^{2}$

The Bulgarian-Yugoslav political and diplomatic conflict was reflected in their internal and foreign policies, but also left a deep mark on the academic, cultural and public spheres of the two countries. Various intellectual, artistic

\footnotetext{
1 See Victor Roudometof (Ed.), The Macedonian Question: Culture, Historiography, Politics (East European Monographs, 2000); Victor Roudometof, Collective Memory, National Identity, and Ethnic Conflict: Greece, Bulgaria, and the Macedonian Question (Praeger Publishers, 2002); Vladislav B. Sotirović, "Macedonia between Greek, Bulgarian, Albanian, and Serbian National Aspirations, 1870-1912," Serbian Studies: Journal of the North American Society for Serbian Studies 23/1 (2009): 17-40.

2 See Živko Avramovski (Ed.), Jugoslovensko-bugarski odnosi u XX veku [Yugoslav-Bulgarian Relations in the $20^{\text {th }}$ Century], Vol. 1 (Belgrade: Institut za savremenu istoriju, Narodna knjiga, 1980); Živko Avramovski (Ed.) Jugoslovensko-bugarski odnosi u XX veku, Vol. 2 (Belgrade: Institut za savremenu istoriju, Narodna knjiga, 1982); Dragan Bogetić, Slobodanka, Kovačević, Hronologija jugoslovensko-bugarskih odnosa 1878-2003 [Chronology of Yugoslav-Bulgarian Relations 1878-2003] (Belgrade: Jugoistok XXI, Centar za evro-balkansku saradnju, 2003);
} 
and political circles contributed to the struggle of their authorities against the neighbors by reproducing or elaborating on the official discourse on Macedonia and Macedonians, as well as interpretations of their ethnical and cultural characteristics. ${ }^{3}$ Despite Yugoslavia's formal sovereignty over Vardar Macedonia, the fear of Bulgarian influence on the "fluctuating" and instable Macedonian identity stimulated extensive work on economic, cultural and political emancipation and integration of this region, and on contesting the validity of Bulgarian claims in the domestic and foreign public. ${ }^{4}$ The actions of Yugoslav authorities were followed by numerous initiatives of Belgrade-based women's, patriotic and academic associations and organizations that aimed at bringing Macedonians closer to the Serbian cultural space and at the same time away from Bulgarian bailiwick. ${ }^{5}$ Musicians and music experts, particularly of Serbian origin, also played role in this process.

Cultural integration of Vardar Macedonia into the Kingdom of Yugoslavia was based to a great extent on the experience of prewar cultural work of the Serbian political and intellectual elite. The same actors and methods were employed, as well as the same ideology. This was also typical for the various activities concerning the performing, research and production in music at the time. As we shall discuss in subsequent sections, not only were interwar musicians and music experts and scholars-intentionally or unintentionally-giving their support to the process of making Macedonians Serbs and Yugoslavs, and consequently defending the Yugoslav position against the Bulgarian stance, but they also followed the directions of their predecessors. Moreover, the idea of ethnical and cultural closeness of Serbs and Macedonians was internalized to such a degree that they felt no need whatsoever to explain it. This phenomenon was brought to light particularly in the studies of traditional folk music of Vardar Macedonia created at the time as well as in the rare debates with foreign researchers on that topic.

\footnotetext{
3 See, for instance, Ljubinka Trgovčević, Naučnici Srbije i stvaranje jugoslovenske države 1914-1920 [Serbian scientists and the establishing of a Yugoslav state 1914-1920] (Belgrade: Narodna knjiga, Srpska književna zadruga, 1986); Sofija Božić, "Makedonija kao sporno pitanje između Srpske kraljevske akademije i Bugarske akademije nauka 1913 [Macedonia as an issue between the Serbian Royal Academy and the Bulgarian Academy of Sciences 1913]," in Balkanski ratovi 1912-1913: nova viđenja i tumačenja, edited by Srđan Rudić, Miljan Milkić (Belgrade: Istorijski institut, Institut za strategijska istraživanja, 2013), 381-392.

4 Cf. Vladan Jovanović, "Demografske odlike Vardarske banovine i problemi samoidentifikacije [The demographic characteristics of the Vardar Banovina, and the problems of self-identification]," Etnoantropološki problemi 1 (2012): 563-584.

5 See the discussion in the following sections.
} 


\section{Cultural initiatives of the Serbian and Yugoslav elite regarding Vardar Macedonia (1860s-1930s)}

Interest for initiating cultural actions on the territory of Vardar Macedonia among the Serbian political and intellectual elite appeared as early as the late 1860s, manifested in the foundation of the Committee for Serbian Schools of Old Serbia and Macedonia (1868-1876), ${ }^{6}$ and after the Serbian-Turkish (1876-1878) and Russian-Turkish (1877-1878) wars also in the various projects aiming at strengthening Serbian influence in the domains of education, religious affairs and publishing. ${ }^{7}$ Alongside the official endeavors of the Serbian government regarding the expansion of educational institutions in Old Serbia and Macedonia under their control, Belgrade-based intellectual circles utilized the stronger presence of Serbian Orthodox Church clerics and Serbian diplomats in this part of the Ottoman Empire, as well as the export of school books and literature, to develop diverse forms of cultural work aimed at intensifying cultural and national bonding of Macedonians with the then Kingdom of Serbia and promoting their cultural heritage in the public. Among them a prominent place belonged to the Saint Sava Society, established in 1886, which assisted the schooling of locals from Old Serbia and Macedonia in Belgrade before the outbreak of the Balkan Wars, helped repair church and school buildings, and published books and materials supporting Serbian aspirations toward these regions. ${ }^{8}$ Certain women's societies and associations also contributed to this process, including the prestigious and influential Circle of Serbian Sisters (Kolo srpskih sestara) founded in 1903.

A number of choral societies as well as musicians took part in the making of Macedonian and Old Serbian traditional culture part of the Serbian national culture, presenting and popularizing its artifacts to the Serbian public. Renowned Serbian composers of the time, most of whom were the leading choirmasters of Belgradebased and provincial amateur ensembles, showed great interest in songs and dances from Macedonia and Kosovo and their artistic remodeling as documented in a detailed study by musicologist Srđan Atanasovski. ${ }^{9}$ Josif Marinković (1851-1931),

\footnotetext{
6 See more in Slaviša Nedeljković, "Delovanje Odbora za škole i učitelje u srpskim oblastima u Makedoniji od 1868. do 1876. [The functioning of the Committee for Schools and Teachers in Serbian areas in Macedonia from 1868 to 1876]," Vardarski zbornik 8 (2011): 283-305.

7 See more in Miloš Jagodić, "Planovi o politici Srbije prema Staroj Srbiji i Makedoniji (1878-1885) [Plans on the policies of Serbia toward Old Serbia and Macedonia (1878-1885]," Istorijski časopis LX (2011): 435-460.

8 See Jovan Hadži-Vasiljević, "Prilike pod kojima je postalo Društvo Sv. Save i njegov rad od postanka do sada [The circumstances of the foundation of the St. Sava Society and its work from the beginning until today]," Bratstvo XVIII (1924): 1-14.

9 Srđan Atanasovski, Mapiranje Stare Srbije. Stopama putopisaca, tragom narodne pesme [The Mapping of Old Serbia: In the Footsteps of Travel Writers, Tracing the Folk Song] (Belgrade: Biblioteka XX vek, 2017).
} 
Isidor Bajić (1878-1915), Vladimir Đorđević (1869-1938) and above all Stevan Stojanović Mokranjac (1856-1914) were intrigued by the music material from these regions, which served as a basis for some of their most appreciated works composed in the late $19^{\text {th }}$ and early $20^{\text {th }}$ century. Apart from using traditional music from Macedonia as a creative source, some composers initiated its preservation and exploration. ${ }^{10}$ In both cases, the narratives of the Serbian political and intellectual elite were typically reflected and reproduced. The idea of national and cultural unity of Serbs and Macedonians was deemed undeniable, and along with it the aspirations of the Kingdom of Serbia for territorial expansion and annexation of Old Serbia and Macedonia. Traditional music from this part of the Ottoman Empire was considered one of the numerous indicators of ethnical similarity between these peoples, and consequently contributed to legitimizing the Serbian elite's political program. ${ }^{11}$

Although the end of the Great War brought the realization of long-awaited political goals of the Serbian elite, specifically concerning the territorial incorporation of Vardar Macedonia into the Kingdom of SCS, 12 this fact did not discourage the continuation of the process of cultural integration of Macedonians. On the contrary, it intensified in the interwar period, which was largely the result of the circumstances faced in the field, such as the lack of strong Serbian and Yugoslav national consciousness among Macedonians and their general volatility regarding the issue of national identity. Consequently, many initiatives took place in the 1920s and 1930s whose aim was to foster stronger bonding of Slavs in this region with the Yugoslav state and society, and to stimulate the appropriation of Serbian and Yugoslav national and cultural identity. For this purpose, the Faculty of Philosophy was founded in Skopje in 1920,13 and soon after, as its important parts, the Scientific Society of Skopje, which published a very esteemed journal, Glasnik Skopskog naučnog društva (The Bulletin of the Skopje Scientific Society), since 1925, as well as the Society for Serbian Language and Literature. Although

\footnotetext{
${ }^{10}$ Ibid., 110-191. Actually, only Mokranjac went beyond the borders of the Ottoman Empire for the purpose of collecting folk tunes (1896, Prishtina). Đorđević and Bajić collected music material in the southern parts of the Kingdom of Serbia, closest to the Old Serbia and Macedonia regions. ${ }^{11}$ Ibid., 110-191. Cf. Biljana Milanović, "Stevan Stojanović Mokranjac i aspekti etniciteta i nacionalizma [Stevan Stojanović Mokranjac and the aspects of ethnicity and nationalism]," in Mokranjcu na dar, edited by Ivana Perković Radak, Tijana Popović Mlađenović (Belgrade: Fakultet muzičke umetnosti, 2006), 33-53; Srđan Atanasovski, "Stevan Stojanović Mokranjac and Producing the Image of Serbian Folk-Song: Garlands from 'Old Serbia' as a Form of Musical Travelogue," Muzikološki zbornik 1 (2014): 75-90.

${ }^{12}$ On the coining of the term Vardar Macedonia see Dejan D. Antić, "Političke prilike i srpski narod u Vardarskoj Makedoniji (1903-1912) [Political circumstances and the Serbian people in Vardar Macedonia]," (PhD diss., Faculty of Philosophy of the University of Niš), 19-23.

${ }^{13}$ See "Pitanje o broju fakulteta (memoar komisije) [The issue of the number of faculties (Commission memoir)]," Prosvetni glasnik 2 (1928): 181-210.
} 
its construction started as early as 1915, after numerous changes to the plans and delays, the National Theater of King Alexander I was opened in Skopje in 1927, and the monumental new building, together with the Skopje theater ensemble, was expected to serve the national interests and contribute to the national and cultural emancipation of "our dear South." 14 Various women's, patriotic, sports and humanitarian organizations that were established in the Kingdom of Serbia before the Balkan Wars opened their branches throughout the urban centers of Vardar Macedonia, at the time part of the South Serbia province, ${ }^{15}$ in order to encourage locals to participate in political, educational, sports or artistic activities, but also to support their overall cultural and economic integration. ${ }^{16}$

A contribution in this process was, similarly to the prewar period, made by musicians and music associations, mostly through the domains of music performances and ethnography (see Figure 1). One of the oldest and most prestigious choirs from Belgrade, the Obilić Academic Choral Society (founded in 1884), regularly organized tours in "South Serbia" from 1923 onward, ${ }^{17}$ which beside concert performances included visits to important places from Serbian recent and distant past, and interaction with local associations and authorities. The intertwining of different tasks was well evidenced through a series of reports created during the Obilić tour around the region called South Serbia in 1925 by writer and journalist Gustav Krklec (1899-1977) published in the daily Vreme (Time). ${ }^{18}$

\footnotetext{
${ }^{14}$ See "Danas se svečano otvara nova zgrada Narodnog pozorišta Kralja Aleksandra I [Today is the ceremonial opening of the new building of the National Theater of King Alexander I]," Vreme (October 27, 1927): 4.

${ }^{15}$ On the administrative divisions of the Kingdom of SCS/Yugoslavia and the naming of the territory formerly known as Old Serbia and Macedonia, see Vladan Jovanović, Jugoslovenska država i Južna Srbija 1918-1929. Makedonija, Sandžak i Kosovo i Metohija u Kraljevini SHS [The Yugoslav State and South Serbia 1918-1929. Macedonia, Sanjak, and Kosovo and Metohija in the Kingdom of SCS] (Belgrade: Institut za noviju istoriju Srbije, 2002), 7-10.

16 See, for instance, "Izveštaj o radu Narodnog ženskog saveza Kraljevine SHS u 1924-25 [Report on the work of the National Women's Association of the Kingdom of SCS in 1924-25]," Ženski pokret 8 (1925): 274-285.

17 The Obilić Academic Choir visited Skopje, Kumanovo, Bitola, Ohrid and Prishtina in 1923, and partly repeated the same route in 1925, 1927, 1933 and 1937. See more in Boro Majdanac, Milena Radojčić (Eds.), Akademsko pevačko društvo Obilić 1884-1941: dokumenti, sećanja, komentari [The Obilić Academic Choral Society 1884-1941: Documents, Memories, Comments] (Belgrade: Istorijski arhiv Beograda, 2005).

${ }^{18}$ Krklec wrote five travelogues, each describing the specific phenomena he and his fellow visitors encountered on tour: "U Dušanovoj prestonici na obalama Vardara [In Dušan's capital on the banks of the Vardar River]," Vreme (July 7, 1925): 5; "U Prizrenu - srpskom Carigradu [In Prizren-the Serbian Constantinople]," Vreme (July 12, 1925): 5; "Sjaj i lepota Visokih Dečana [The brilliance and beauty of Visoki Dečani] Vreme (July 17, 1925): 3; "Tragovima Albanske golgote [In the footsteps of the Albanian Golgotha]," Vreme (July 21, 1925): 4; "Srce Metohije. Varošica Peć, sedište stare srpske Patrijaršije i njena okolina [In the heart of Metohija. The town of Peć/Peja, the seat of the old Serbian Patriarchy and its surroundings]," Vreme (July 24, 1925): 6.
} 
Krklec emphasized in his miniatures the commemorative and historical aspects of the tour with references to the Albanian Golgotha of the Serbian army during the WWI, Serbian Emperor Dušan's 14th century capital (Skopje), the greatness of his father's and his endowment Visoki Dečani, and at the same time tried to depict the specific atmosphere of South Serbian urban areas, mostly unknown to his readers. It was through these and similar occasions that Macedonians were given the opportunity to listen to what was considered core Serbian and Yugoslav artistic music, part of which was inspired by their own local traditional music (see Figure 2). Whether the familiarity of the tunes made an impression on the local audience, and whether the contact with the dominant musical culture (Serbian and Yugoslav) had an impact on the understanding of the musical heritage of that region is, unfortunately, hard to conclude from the short and uninformative press reports, which are mostly completely oblivious to the views of the locals.

The idea of indivisibility of Macedonian, Serbian and Yugoslav music that was reflected in the sphere of music performance was even more accentuated in the music ethnography undertakings of the 1920s and 1930s. The great interest in researching the traditional folk music of Vardar Macedonia was primarily expressed by Serbian scholars soon after the Great War. It was brought to light in their correspondence with the Arts Department of the Ministry of Education as well as the writings they published in the daily press, music periodicals and scientific journals. ${ }^{19}$ The fact that this region was generally unexplored and that very few scholars of Serbian origin had the chance to explore its musical heritage in situ since the late $19^{\text {th }}$ century, along with the assumption that traditional folk music was rapidly disappearing owing to the expansion of popular music practices, led them to believe in the necessity of broad and systematically conceived fieldwork on the territory of South Serbia. ${ }^{20}$ Despite the enthusiasm and willingness they displayed for conducting such research, there were many financial and organizational obstacles that stood on their way. In fact, problems regarding the creation of an adequate institutional framework for conducting ambitious research projects propagated by Serbian scholars persisted throughout the interwar period particularly in Belgrade, contributing to a large extent to a reduced number of field studies and frequent changes to research plans.

\footnotetext{
${ }^{19}$ Details will be discussed in the next section.

${ }^{20}$ Cf. Ivana Vesić, Konstruisanje srpske muzičke tradicije u periodu između dva svetska rata [The Constructing of the Serbian Music Tradition in the Period between the Two World Wars] (Belgrade: Muzikološki institut SANU, 2018), 231-235.
} 


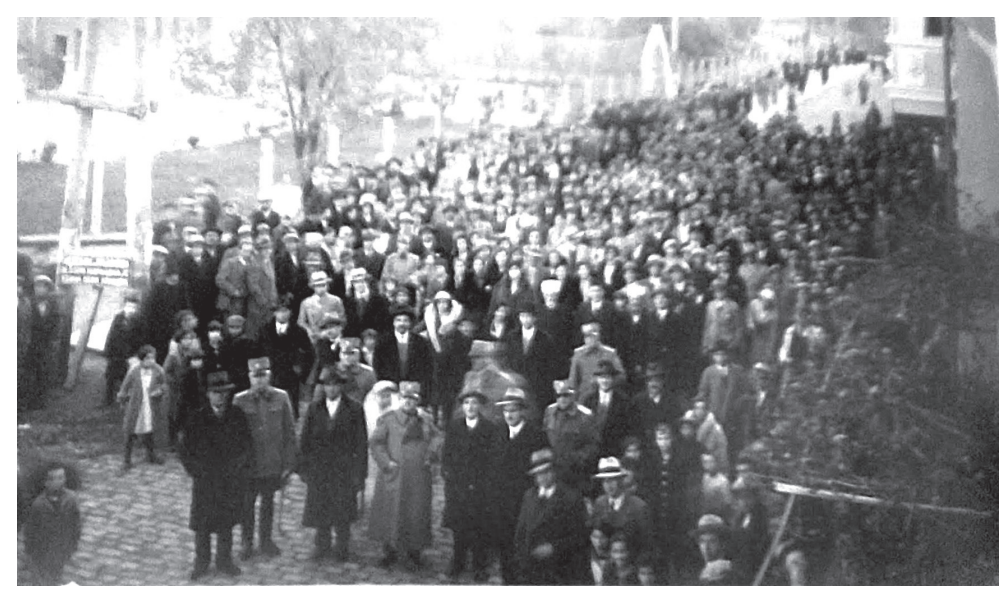

Figure 1. A tour of Music Society of Novi Sad around Serbia and South Serbia (1932), a scene from Bitola. Institute of Musicology SASA,

Legacy of Svetolik Pašćan Kojanov, unsigned.

Th IOI TOKPOBHT $\mathrm{KPABA}$ JУ AЛЕКСAH A ЈУЖНОС CABE3HO M HOBOM CAДY

TУРНG КРОЗ СРБИЈУ И ЈУЖКНУ СРБИЛУ

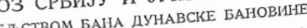
ПОЛ ПОКРОВИТЕЛСТВОМ БАНА ДУНАВСКЕ БАНО НИ ГOCIOДИНA MUЛАНA HИKOЛИTA

\section{Iротрам коншерта} јутословенске хорске музике KРУUЕВАШ НИШ ЛЕСКОВАI $\begin{array}{ll}\text { ТЕТОВО } & \text { СКОПЈЕ } \\ \text { БИТОЉ } & \text { ПРИЛЕП }\end{array}$ од 19 до 27 новембра 1932 године

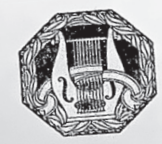

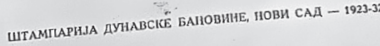

Figure 2. Concert program of the Music Society of Novi Sad for the tour around Serbia and South Serbia dedicated to Yugoslav choral music (November 19-27, 1932). Institute of Musicology SASA, Legacy of Svetolik Pašćan Kojanov, unsigned. 
Field research in Vardar Macedonia (and Kosovo) in the interwar period

That an institutional basis was a prerequisite for a systematical approach to collecting traditional folk music was clear to musicologists from Zagreb and Belgrade, who began to look for support from state authorities and already established cultural and scientific institutions as soon as 1920. Almost simultaneously, music scholars from both centers were looking for possible solutions to the problem of musical folklore research, so they turned to the officials of certain cultural institutions and state bodies. Musicologist and composer Božidar Širola (1889-1956) contacted the Ethnography Department of the Croatian National Museum in Zagreb, ${ }^{21}$ while his fellow musician and scholar Miloje Milojević (1884-1946) developed cordial relations with the Ethnographic Museum in Belgrade. ${ }^{22}$ The two institutions, together with the Ljubljana Royal Ethnographic Museum, became central in the process of collecting and exploring traditional music of different regions of Yugoslavia in the interwar period, although they faced many problems in achieving formal acknowledgement and proper financial support from the state for their folk music departments. ${ }^{23}$

Interestingly, the music material from Vardar Macedonia aroused interest and curiosity of both Belgrade and Zagreb in the 1920s, and as soon as the late 1920s Šrola went on fieldwork in the region of Lake Dojran, visiting, among others, the towns of Gevgelia and Kavadarci and writing down thirty melodies and various notes on folk dances, instruments and instrument playing. ${ }^{24}$ Since the Department of Folk Music he led as part of the Croatian National Museum started to use the phonograph in research in 1922, an idea was tabled two years later to organize field research in South Serbia in collaboration with music scholars from Belgrade. By that point, the Belgrade Ethnographic Museum had already established collaboration with Milojević, ${ }^{25}$ and Vladimir Đorđević, an able and esteemed folk music transcriber. However, despite the proposal of the museum's official Nikola Zega to the Serbian Royal Academy of Sciences to establish a Folk Music Department based on the claim that "collecting our folk melodies and songs is as significant as

\footnotetext{
${ }^{21}$ See Božidar Širola, Milovan Gavazzi, “Muzikološki rad Etnografskog muzeja u Zagrebu od osnutka do konca g. 1929 [Musicological activities of the Zagreb Ethnographic Museum from its foundation until the end of 1929]," Narodna starina 25 (1931): 3-80.

${ }^{22}$ See The Archives of Yugoslavia [Arhiv Jugoslavije (AJ)], Fond of the Ministry of Education of the Kingdom of Yugoslavia [Ministarstvo prosvete Kraljevine Jugoslavije] (66), 643-1067, Miloje Milojević, composer and teacher at the Third Belgrade Gymnasium to the Ministry of Education, March 24, 1920, Belgrade.

${ }^{23}$ Cf. Ivana Vesić, Vesna Peno, "Kosta P. Manojlović: A Portrait of the Artist and Intellectual in Turbulent Times," in Kosta P. Manojlović (1890-1949) and the Idea of Slavic and Balkan Cultural Unification, edited by Vesna Peno, Ivana Vesić, Aleksandar Vasić (Belgrade: Institute of Musicology SASA, 2017), 17-19; Širola, Gavazzi, "Muzikološki rad," 6-20.

24 Širola, Gavazzi, “Muzikološki rad,” 5.

${ }^{25}$ See Vesić, Peno, “Kosta P. Manojlović,” 18-19.
} 
the investigation and collecting of folk customs," it was not brought to fruition. ${ }^{26}$ This meant that the museum was open to experts who wanted to conduct field research, but was not able to support them financially. Instead, they were procured the material they needed and were probably provided expert assistance by the museum's employees. Still, the motives behind the organization of joint research by scholars from Zagreb and Belgrade for the purpose of phonographic recording of music in South Serbia are hard to discern from the available sources. Probably the Belgrade scholars were the initiators, and in the absence of their own equipment (phonograph) they decided to contact their colleagues in Zagreb, who were not only using phonographic recording in the field, but were also well informed on the technical part of the process. According to a preserved memo of the Zagreb museum's officials, joint field research was planned for the summer of 1924, and it was meant to include ethnologist Milovan Gavazzi (1895-1992) on their part. ${ }^{27}$ At first, the Ministry of Education gave approval for Vladimir Đorđević to represent the Belgrade museum, but subsequently replaced him with Kosta Manojlović (1890-1949), at the time a teacher at the Second Male Gymnasium in Belgrade. 28 Zagreb officials suggested the fieldwork be postponed to the autumn of 1924, since there were "insufficient wax plates, a malaria epidemic struck the region, there was ample seasonal work in rural areas," and they had also already made plans for a similar undertaking with Czech artist and passionate transcriber of folk tunes Ludvík Kuba (1863-1956). The joint project was never completed, but Manojlović, who was supposed to participate in it, managed to conduct a five-week research in the summer of 1924, visiting a number of places in Vardar Macedonia and Kosovo, and collecting 390 tunes. ${ }^{29}$ This fieldwork was most likely supported with the funds approved for the joint project. ${ }^{30}$

Manojlović's large-scale exploration of South Serbia was the first of its kind since the $19^{\text {th }}$ century, and as such attracted the interest of some of Belgrade's influential intellectual circles. One of the most prolific music critics and provocative writers at the time, Stanislav Vinaver, wrote an extensive and very inspired essay for the daily Vreme, where he presented some of Manojlovićs findings without hiding

\footnotetext{
26 See AJ, 66-643-1067, Belgrade Ethnographic Museum to the Arts Department of the Ministry of Education, No. 253, August 14, 1925, Belgrade.

27 See AJ, 66-643-1072, Ethnographic Department of the Croatian National Museum to the Arts Department, No. 70, June 27, 1924, Zagreb. Cf. Vesić, Peno, “Kosta P. Manojlović," 19.

28 Vesić, Peno, "Kosta P. Manojlović," 19.

${ }^{29}$ Based on Manojlović's testimony, it was not the first time he visited and explored this area. A year before (in 1923) he spent 15 days in Bitola, but the exact motives and results of this short fieldwork were left unexplained. See Kosta P. Manojlović, "Muzičke karakteristike našega Juga [Musical characteristics of our South]," Sveta Cecilija 5 (1925): 139.

${ }^{30}$ See Stanislav Vinaver, "Narod u punom jeku stvaranja. Otkrića i slutnje g. Koste Manojlovića [People in full creative swing. Findings and premonitions of Mr. Kosta Manojlović]," Vreme (October 2, 1924): 6.
} 
his enthusiasm. Vinaver depicted the trip through the prism of personal heroism of the researcher, his ascetic approach, strong devotion and discipline. ${ }^{31}$ As he stated:

Mr. Kosta Manojlović, who recently returned from South Serbia, is talking passionately about the harvest of motifs, folk motifs he found and collected there. He was given a meagre support of 4,000 dinars from the Arts Department [of the Ministry of Education], and he began his journey with a lot of love and austerity, living in very poor conditions, sleeping in stables, visiting the cottages of poor peasants, entering the shanties, where he wrote down the precious melodies of those people under candle light. [...] He would go to sleep after midnight, waking up before dawn, and rushing to places where he had heard there were good singers or old souls who once used to sing and were able to recall it. ${ }^{32}$

Vinaver's exuberant portrayal of Manojlovićs field research and his excited depiction of the specific qualities of "musicality" of South Serbians were meant not only to capture the attention of Vreme readers but they also laid the ground for similarly poetical representations of South Serbia by Gustav Krklec in his aforementioned reports on the Obilić tour and by Stanislav Krakov, who wrote a series of travelogues in the same paper in 1925. ${ }^{33}$

Manojlović used part of the collected material for the studies he published in Glasnik Profesorskog društva (The Bulletin of the Professors' Association), the journal Sveta Cecilija (Saint Cecilia) and Glasnik Etnografskog Muzeja (The Bulletin of the Ethnographic Museum) in 1925 and 1926. ${ }^{34}$ The findings from his fieldwork also served as a basis for his lengthy discussion intended for broader public titled Muzičko delo našeg sela (The Musical Oeuvre of Our Peasants) from 1929. Apart from presenting a portion of his transcriptions from the field, together with his insights and assumptions regarding the relations of traditional folk music of Vardar Macedonia with Serbian and Yugoslav musical folklore, Manojlović decided to catalogue the written tunes and create a collection within the Ethnographic Museum in Belgrade (see Figure 3). ${ }^{35}$ For that purpose, the museum's director Nikola Zega approved the printing of special forms needed for cataloguing.

\footnotetext{
${ }^{31}$ Ibid.

32 Ibid.

${ }^{33}$ Krakov's writings were published in September issues of Vreme. Cf. Vidosava Golubović, Letopis kulturnog života, 1919-1925: Vreme, Politika, Pravda [Chronicle of Cultural Life, 1919-1925: Vreme, Politika, Pravda] (Belgrade, Novi Sad: Institut za književnost i umetnost, Matica srpska, 1989), 352. ${ }^{34}$ Manojlović's writings on South Serbia from this period are listed in Srđan Atanasovski, "Kosta P. Manojlović and Narratives on 'Southern Serbia'," in Kosta P. Manojlović (1890-1949) and the Idea of Slavic and Balkan Cultural Unification, edited by Vesna Peno, Ivana Vesić, Aleksandar Vasić (Belgrade: Institute of Musicology SASA, 2017), 109-126.

35 See Manojlović, “Muzičke karakteristike našega Juga," 180; AJ, 66-643-1067, Ethnographic Museum in Belgrade to the Arts Department of the Ministry of Education, No. 253, August 14, 1925, Belgrade.
} 


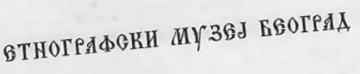

MYรHYКH DONKAOP

\section{5}

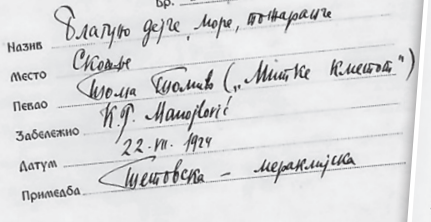

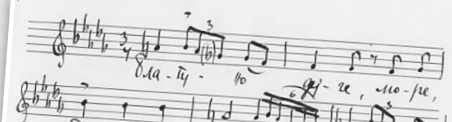

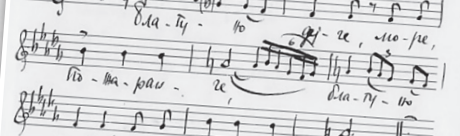



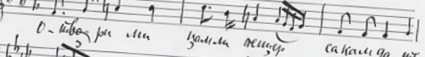

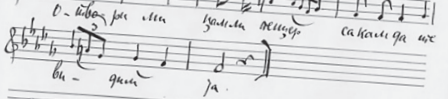

ia



Figure 3. Filled-in form with data on the song "Blaguno dejče, more, požaranče" written down in Skopje on July 22, 1924. Institute of Musicology SASA, Kosta P. Manojlovićs digitized catalogues.

A year after Manojlović completed his field study, Vladimir Đorđević initiated an ambitious, four-month fieldwork aiming at exploring the various parts of South Serbia, particularly areas in Vardar Macedonia. This broad and detailed research was conducted without financial support from the state although Đorđević hoped for its assistance. Parts of his findings were published in Glasnik Skopskog naučnog društva in 1926, ${ }^{36}$ but the majority was presented in a large collection entitled Srpske narodne melodije (Južna Srbija) (Serbian Folk Tunes of South Serbia) published by the Skopje Scientific Society in 1928. It was the first collection of folk tunes that appeared in the "Serbian" part of the kingdom before the WWII, and the only one dedicated to the heritage of South Serbia. Unlike Manojlovićs undertaking, which was publicly admired and warmly received, Đorđevićs historically important publication received only a short, although very affirmative notice in the daily Pravda, primarily owing to its critic Petar Krstić, who valued Đorđevićs folk music research highly. ${ }^{37}$ With the exception of Krstić, who never missed an opportunity to point to

\footnotetext{
36 Đorđević explained how he used the material he collected and where the findings were published in the Preface to his second collection of folk tunes from prewar Serbia (Srpske narodne melodije: Predratna Srbija, Belgrade, 1931, XI).

37 See Petar Krstić, "Srpske narodne melodije (Južna Srbija). Skoplje, 1928 [Serbian folk tunes (South Serbia). Skopje, 1928],” Pravda (January 27, 1928): 7.
} 
his fellow composer and musicologist's precious work, ${ }^{38}$ other influential figures of musicology in Belgrade, particularly Milojević and Manojlović, were very reserved in this respect. ${ }^{39}$ Although further research would be needed to confirm this, the attitude of the musical authorities might have contributed to a sort of lukewarm reception of Đorđevićs collection at the time in both the professional and general public in Serbia and Yugoslavia.

Almost at the same time as Đorđević, this area was visited and explored by Czech painter and dedicated folklorist Ludvík Kuba, who was determined to complete his decades-long research on the traditional folk music of all Slavs, as well as his published series Slovanstvo ve svých zpèvech (Slavs in Their Songs), which he started in 1884. Kuba was well known among Yugoslav scholars, and his research and findings were followed with great interest and appreciation, particularly in Zagreb. ${ }^{40}$ The journal Sveta Cecilija published a number of his studies in the interwar period, and many reports regarding his work. Kuba's trip to South Serbia in the summer of 1925, the only Yugoslav region he had not had the chance to visit, attracted attention of several prominent Yugoslav papers. Announcing this undertaking, the daily Vreme praised Kuba's efforts and methodology in collecting Slavic and Yugoslav folk songs. ${ }^{41}$ Trying to underline his skillfulness and talent, the journalist referred to the words of Stjepan Radić, the leader of the Croatian Peasant Party, who claimed that none of Croatian politicians understood Dalmatia as fully as this Czech folk-music connoisseur. The Zagreb-based Nova Evropa (New Europe) magazine published an interview with Kuba after he finished his three-month South Serbia fieldwork focusing on the folk costumes and songs of

\footnotetext{
${ }^{38}$ See Ivana Vesić, "Konstruisanje srpske muzičke tradicije u periodu između dva svetska rata: uticaj ideoloških podela u srpskoj političkoj i intelektualnoj eliti [The construction of Serbian music tradition in the period between the two world wars: the influence of the division in the Serbian political and intellectual elite]," (PhD diss., Faculty of Philosophy of the University of Belgrade, 2016), 131.

${ }^{39}$ Still, as ethnomusicologist Dragoslav Dević claimed, Đorđević's collection was of great importance for Milojević during his field research in Vardar Macedonia. His personal copy was always close to him and he wrote down variants of tunes and lyrics in it with a red pen. See Dragoslav Dević, "Miloje Milojević, melograf i etnomuzikolog [Miloje Milojević collector of folks songs and ethnomusicologist]," in Narodne pesme i igre Kosova i Metohije, edited by Dragoslav Dević (Belgrade: Zavod za udžbenika i nastavna sredstva, Karić fondacija, 2004), 10. Unfortunately, at the time Dević conducted his exploration on Milojevićs ethnomusicological work, this copy was not at his disposal as it was displaced. The author of this chapter found this copy in the archival material of the Institute of Musicology SASA and, as soon as it is digitized, it will be available to all interested researchers.

${ }^{40}$ See, for instance, Božidar Širola, "Ludvik Kuba. O 60-godišnjici njegova života [Ludvík Kuba. On the occasion of his $60^{\text {th }}$ birthday]," Sveta Cecilija 4 (1923): 97-98.

41 "Srpske narodne melodije najinteresantnije su u Evropi. Razgovor sa g. Ludvikom Kubom, pred njegov put u Južnu Srbiju [Serbian folk tunes are the most interesting in Europe. An interview with Mr. Ludvík Kuba ahead of his journey to South Serbia]," Vreme (July 17, 1925): 4.
} 
that region. ${ }^{42}$ While showing respect and admiration for Kuba's lifelong project of collecting Slavic folk music, the journalist expressed particular curiosity in his impressions and judgements on South Serbian folk culture with respect to the longstanding political and diplomatic disputes between Serbs and Bulgarians. The Czech folklorist declared himself an ardent supporter of Pan-Slavism, and as such was very critical of the "fragmentation, either political or cultural," among Slavs at the time, especially South Slavs.

As a result of his field research, Kuba prepared a study on traditional Macedonian folk music, which was bought by the Folk Music Department of the Croatian National Museum, together with a portion of the transcribed material, and published in the Sveta Cecilija journal in 1927, owing much to the efforts of Milovan Gavazzi, the museum's curator, who was doing a doctorate in Prague in that time. 43

Before Miloje Milojević conducted his own fieldwork in the regions of Vardar Macedonia and Kosovo between 1927 and 1930, ${ }^{44}$ another joint project was proposed for collecting the music materials of these areas with a phonograph. This time the Zagreb Museum gave the initiative, asking other Yugoslav national and ethnographic museums for their contributions. ${ }^{45}$ The recording of South Serbian folk music was to be part of a very meticulously and ambitiously planned program that would be presented at the international exhibition Musik im Leben der Völker (Music in the Lives of the Peoples) organized in Frankfurt from early June until the end of August 1927 with the support of the Weimar Republic government. Museum officials wished to send Kosta Manojlović and Vladimir Đorđević to make phonographic recordings of selected melodies in the field, as well as to create "hard copies" of the wax plates. In order to display the richness of Yugoslav folk music from different parts of the country to the German and global public, authorities considered recordings, written accounts, published material and different objects including musical instruments, as well as a series lectures by domestic and foreign scholars. Among the lecturers to be invited were Ludvík Kuba, Curt Sachs and Robert Lach. Unfortunately, due to lack of financial support, the detailed and carefully conceived program of the musicologists and ethnologists from Zagreb was not realized. The absence of proper engagement of the Yugoslav political elite, specifically of the Ministry of Education

\footnotetext{
42 Jovan Kršić, "Ludvik Kuba u Makedoniji (jedan razgovor) [Ludvík Kuba in Macedonia (interview)]," Nova Evropa 1 (1926): 19-23.

${ }^{43}$ See Ludvík Kuba, "Pučka glazbena umjetnost u Makedoniji [Folk music art in Macedonia]," Sveta Cecilija 1, 2 (1927): 25-27, 76-81. Cf. Širola, Gavazzi, “Muzikološki rad,” 10.

44 See Dragoslav Dević, "Miloje Milojević, melograf i etnomuzikolog," 10.

45 See AJ, 66-634-1072, The memos of the Department of Folk Music of the Croatian National Museum/Croatian Ethnographic Museum to the Arts Department of the Ministry of Education on the Musik im Leben der Völker exhibition, No. 27/1, 1927, Zagreb; No. 27-6/1927, April 23, 1927, Zagreb; No. 27/8, 1927, Zagreb, May 24, 1927.
} 
and its Arts Department, triggered vigorous reactions of certain intellectual circles, which underlined with great disappointment the alleged detrimental effects of the country's unsystematic approach to cultural diplomacy. 46

Milojević conducted his field research in the areas of both Vardar Macedonia and Kosovo in the summer months for four consecutive years (1927-1930) (see Figure 4). As he was appointed associate professor at the Faculty of Philosophy in 1927, where he worked since 1925, it is possible that the first and some of his later trips were supported financially by the Belgrade University. In August 1928, Milojević turned to the Minister of Education, requesting material support in order to complement his previous research with more data from the field. In the letter, he also revealed his plan to prepare a publication on South Serbian traditional folk music, which he found necessary to support the "issue of our South regarding the national perspective" and at the same time "contradict the thesis of Bulgarians." 47 Although the Ministry of Education had no spare funds at its disposal for Milojevićs proposals, he continued his explorations in the following years. His first findings were presented in the several public lectures that took place in 1928 and 1929. As a member of a group of university professors under the patronage of the Ilija M. Kolarac Foundation, ${ }^{48}$ Milojević - accompanied by his wife, concert singer Ivanka Milojević-held a series of lectures on the traditional folk music from South Serbia, illustrated with song performances, in Skopje, Veles, Štip, Strumica, Prilep, Bitola, Ohrid and Kumanovo. ${ }^{49}$ His thoughts on South Serbian music presented on these occasions were published later that year in a standalone publication Južna Srbija u našoj kulturi. Narodna muzika Južne Srbije [South Serbia in our culture. The traditional folk music of South Serbia] (Belgrade, 1928). In June 1929, upon invitation by Jan Branberger, the dean of the Prague State Conservatory, Milojević spoke on the specific characteristics of Serbian traditional folk music to the Prague audience, focusing primarily on the South Serbian part. ${ }^{50}$ The lecture captured the interest of Czechoslovaks, but mostly because of the political incident instigated by Bulgarian students, who-embittered by Milojević's views on Vardar Macedonia-protested

\footnotetext{
${ }^{46}$ See Miloje Milojević, "Muzički pregled. Za spas naše muzičke kulture. Povodom muzičkog festivala u Frankfurtu na Majni [Music review. For the preservation of our music culture. On the occasion of the music festival in Frankfurt]," Srpski književni glasnik XXI/4 (1927): 296-301.

47 See AJ, 66-373-608, Miloje Milojević, composer and associate professor, to the Minister of Education, August 25, 1928, Belgrade (with the response of the General Department of the Ministry of Education, Pbr. 13495, August 25, 1928, Belgrade).

${ }^{48}$ See "G. Vladimir Ćorović o predavanjima Kolarčevog univerziteta po Južnoj Srbiji [Mr. Vladimir Ćorović on the lectures of the Kolarac University around South Serbia]," Vreme (February 15, 1928): 4.

${ }^{49}$ See "Kolarčev univerzitet u Južnoj Srbiji [The Kolarac University in South Serbia]," Vreme (February 15, 1928): 3.

50 See Srečko Koporc, “O srbski narodni pesmi [On Serbian folk songs]," Cerkveni glasbenik 9/10 (1929): 139-140.
} 




Figure 4. Miloje Milojevićs written down variants of tunes and lyrics of songs from Vardar Macedonia in his personal copy of Vladimir Đorđevićs 1928 collection. Institute of Musicology SASA.

furiously and left the event. ${ }^{51}$ Apart from the public lectures, Milojević also discussed materials and findings from his field research at the Third Congress of Slavic Geographers and Ethnographers in 1930, ${ }^{52}$ and almost a decade later in the prestigious literary and academic journal Srpski književni glasnik (Serbian Literary Gazette). ${ }^{53}$ Despite the announcement in the correspondence with the Ministry

\footnotetext{
51 Ibid., 140.

52 His work entitled "Nekoje odlike muzičkog folklora Južne Srbije" [Some characteristics of the musical folklore of South Serbia] was published in the proceedings of the Congress (Zbornik III Kongresa slovenskih geografa i etnografa u Kraljevini Jugoslaviji /1930/, Belgrade: Pripremni odbor II KSGGE, 1933, 235-246) and separately (Belgrade: Štamparija Davidović, 1932). Part of his finds were published in the second volume of his collection of studies and essays in 1933, in two chapters: "Jedna porečka pesma o Karađorđu [One song from Poreče region on Karađorđe]" and "Za tragom narodne melodije našeg juga [On the footsteps of folk melodies of our South]" (Belgrade: Izdavačka knjižarnica Gece Kona). They represent enlarged versions of Milojević's articles published in Politika in 1929 and 1930. 53 Miloje Milojević, "O tipu narodnih melodija Južne Srbije i o njihovoj izražajnoj snazi [On folk tunes of South Serbia and their expressive potential]," Srpski književni glasnik LVI/6 (1939): 441-446.
} 
of Education, Milojević never completed the book on the folk music practices of South Serbia, leaving a large portion of the collected material unpublished.

By the end of the 1920s, the "Serbian" part of the Kingdom was the only one that did not possess proper equipment for recording sound in field research, and these unfavorable circumstances were only changed owing to the efforts of the officials of the Belgrade Ethnographic Museum and its voluntary curator Kosta Manojlović. After a phonograph was procured in 1930, Manojlović, together with the museum's director and ethnologist Borivoje Drobnjaković and photographer Petar Petrović, made recordings in the area of the then Vardar Banovina (large part of former South Serbia) in 1931, and a year later (without Drobnjaković) in Debar, Struga, Ohrid, Bitola and Skopje. ${ }^{54}$ Due to technical problems with copying the wax plates to a more stable medium, phonograph recording in the field under the museum's supervision stopped. ${ }^{55}$ Manojlović continued his research in this area in the early 1940s under the patronage of the Belgrade Music Academy, where he was Chancellor (1937-1939) and professor. ${ }^{56}$

\section{Traditional folk music of Vardar Macedonia}

in relation to Serbian and Yugoslav music from the musicology perspective

With respect to the interest and general approach of Serbian musicologists to Macedonian folk music, several phenomena can be singled out. Firstly, throughout the interwar period and especially during the 1920s, the territory of Vardar Macedonia and partly Kosovo represented an area of particular significance for Serbian researchers concerning the collection and exploration of musical folklore. This is evidenced by the number and design of field studies that took place after the end of the Great War. No other region in the Kingdom of SCS/Yugoslavia has drawn such attention of Serbian music scholars and ethnographers of the time. Judging by the explanations they gave in the published results of their research, correspondence and reports in the press, there were several reasons why the area of Vardar Macedonia was an object of enormous interest to them. As already pointed out, one was the fact that this region had not been thoroughly investigated before since it belonged to the Ottoman Empire and could not be easily reached

\footnotetext{
${ }^{54}$ See Borivoje Drobnjaković's reports on the work of the Ethnographic Museum published in the museum's Bulletin (Glasnik Etnografskog muzeja) 5 (1930): 168-171, 6 (1931): 145-149, 7 (1932): 147-152; Cf. Danka Lajić Mihajlović, “Trag muzike urezan u vosku: kolekcija fonografskih snimaka iz Muzikološkog instituta SANU [The trace of music in wax: the collection of phonographic recordgings from the Institute of Musicology SASA]," Muzikologija 23 (2017): 239-258. Manojlovićs insights from these undertakings were published in the museum's journal in 1933 and 1935.

${ }^{55}$ Lajić Mihajlović, “Trag muzike urezan u vosku," 242-243.

56 See Dragoslav Dević, "Sakupljači narodnih melodija u Srbiji i njihove zbirke [The collectors of the folk tunes of Serbia and their publications]," Glasnik Etnografskog muzeja 22-23 (1960): 109.
} 
by researchers from neighboring countries. Another reason came from the belief in its authenticity. To be more specific, traditional folk music from this area was considered closer to the ancient Slavic musical practices because it was not influenced by other cultures as much as the music of other areas. The slow penetration of "civilizational" processes in this part of the former Ottoman Empire was thought to have resulted in the preservation of the authenticity of Vardar Macedonia's musical folklore and its centuries-old elements. The idea that the music from this region, as well as the region of Kosovo, represents the most typical product of South Slavs and Yugoslavs was suggested by composer Petar Konjović as early as 1920, and as it turned out in the coming years it resonated with the stances of most Serbian musicologists. Manojlović, for instance, emphasized the "purity" of the Slavic melodies particularly from the Poreče region (west Macedonia), ${ }^{57}$ while Milojević believed that the deeper layers expressed in South Serbian tunes bore the imprint of the authentically Slavic (South Slavic) character. ${ }^{58}$

Even more important for musicologists was the "originality" of the folk material from Vardar Macedonia and its extraordinary aesthetic qualities. This aspect held a prominent place in the discussions of Manojlović and Milojević. In his first writings after his field research, Manojlović was mesmerized by the polyrhythmic structure of the tunes of Vardar Macedonia (and Kosovo), and claimed that this element "is the most important characteristic of Yugoslav music," making the music from this region more interesting than the music of other parts of Yugoslavia. ${ }^{59}$ The constant changes in meter, together with metric accents, reminded him of modernist music, particularly of the early works of Igor Stravinsky. ${ }^{60}$ The impressive rhythmic qualities of music from South Serbia were also described with a passion in Vinaver's article, which he wrote as his artistic reshaping of Manojlović first-hand insights and testimonies from the field. As Vinaver noted referring to the material from the Poreče region: "The general characteristic of these ancient songs is the sudden change of rhythm. It cannot even be written down. Polyrhythm follows the song's psychology. [...] Particularly touching are the unusual rhythms, unusual in their frequent changes, in the songs about the Turkish villain Džemo, and the Serbian revenge." 61

Manojlović found melodic aspects of traditional folk music from South Serbia no less interesting than the rhythmic stressing and the modal basis of a majority of the collected material instead of the Western European major-minor

\footnotetext{
${ }^{57}$ Kosta Manojlović, Muzičko delo našeg sela [The Musical Oeuvre of Our Peasants] (Belgrade: Štamparija Tucović, 1929), 31.

58 Milojević, "O tipu narodnih melodija," 443.

${ }^{59}$ Manojlović, “Muzičke karakteristike,” 144, 139.

60 Ibid., 139.

61 Vinaver, "Narod u punom jeku stvaranja," 6.
} 
scale system. ${ }^{62}$ The only element that was not typically Slavic was the presence of the augmented second, which he interpreted as an influence of the Orient, 63 although, as he believed, not without potential and very interesting "for use in artistic music [...] since it became an integral part of our [Slavic] soul." The idea of assimilation of foreign, particularly oriental elements and their integration into the traditional folk music of this region was also underlined in the writings of Milojević and Đorđević. The latter was convinced that the "foreign components and features were not as they were in our music. They were given our character. They were redone and reshaped in our manner." In the same sense, Milojević believed that the South Serbian peasant:

created a synthesis of oriental and his own racial [ethnic] musical elements, with all the power of his sensibility and fantasy, and brightened up that synthesis with all the necessary attributes of his racial [ethnic] ego. This way he also succeeded to refract the oriental musical elements through the prism of his particularity, adapting them to his racial [ethnic] psyche, and depriving them of all the specific characteristics of oriental music mentality, in other words: he fertilized his soul and fantasy with the folk elements from the East, but did not imitate them literally, using instead their marks to make on his own the most beautiful folk melodies, ours and Balkan; ours because they are Balkan; and Balkan, that is ours. ${ }^{64}$

The assumption that foreign elements were well integrated into the musical material of South Serbia (and other regions), and that the amalgamation yielded interesting and aesthetically remarkable results ran contrary to the dominant views of music scholars expressed in the 1920s, when most of them thought it essential to preserve the purity of musical folklore, along with an elimination of unauthentic elements. ${ }^{65}$ The possible cause of the shift in their interpretations could be that the researchers became better acquainted with the material from the field by the late 1920s compared to the previous period, since it was unavailable before the mid-1920s.

Similarly to Manojlović, Milojević also believed that the music from South Serbia, especially its upper, surface layers, had an exceptional beauty to them in comparison with music from "other Serbian, Croatian and Slovenian provinces in Yugoslavia." ${ }^{66} \mathrm{He}$ explained it with the specific circumstances in which Slavic peasants lived under the Ottoman rule, namely with their "need to focus on themselves, [...] and, as they were full of emotional intensity and vivid fantasy to which

\footnotetext{
${ }^{62}$ Manojlović, "Muzičke karakteristike," 175.

${ }^{63}$ Ibid.

${ }^{64}$ Milojević, "O tipu narodnih melodija," 443-444.

${ }^{65}$ See Vesić, Konstruisanje srpske muzičke tradicije, 235.

${ }^{66}$ Milojević, "O tipu narodnih melodija," 442.
} 
they ought to give vent, they found it living in silence, withdrawn in the hardly accessible parts of the Balkans, in dialogue with their own sullen and terrified soul, full of yearning and dreams." ${ }^{7}$ From Milojevićs perspective, the continuous solitude intertwined with deep sorrow and "racial specificity" made South Serbians from the banks of the Vardar River, the slopes of Balkan mountains and the lakes of Dojran, Ohrid and Prespa the real poets.

Common to researchers of Vardar Macedonia's musical folklore was the assumption that it represented an integral part of the Serbian and Yugoslav music "idiom," finding evidence in certain characteristics it shared with the folklore of other regions of the country. The distinction manifested in the emphasis they put on its relatedness to the Serbian cultural space. Milojević and Đorđević followed to a great extent the terminology and discourse of Yugoslav (and Serbian) policies, not only by designating the folklore of this area as South Serbian, but also by adhering to the tripartite ethnic division of the kingdom into Serbian, Croatian and Slovenian regions. Milojević still clung to both the South Serbian label and the ethnic delineation in the 1930s when it was no longer in use, similarly to other musicologists, experts and academics. Kosta Manojlovićs approach to terminology was more complex. Although he did refer to South Serbia in several of his articles in the 1920s and 1930s, most of his writings on folklore at the time inclined toward the position of integral Yugoslavism with a strong influence of Pan-Slavism. Such a position disregarded the ethnic differences within Yugoslavia as insignificant for the exploration of folk music and emphasized the importance of geographical and ethnographical differentiation. Therefore, it is not surprising that Manojlović spoke primarily in terms of regions of the kingdom and their interconnections evident in different elements-similarity of rhythmic and melodic patterns, expressive tools, intervals, scales, etc. The interconnections were embedded in the sameness of the ethnic basis, above all Yugoslav and its very close South Slav version. According to Manojlović, the music of Vardar Macedonia showed distinctive features in comparison with the music north of the Šar Mountains-particularly Old Raška, Šumadija, Kosovo, Sandžak and Bosnia and Herzegovina-which contained certain common characteristics: "a serene musical thought, even with the combined rhythms, with deep sorrow and sensitivity, and something pastoral [...]." 68 Still, the regional specificities did not contradict the cohesion of the Yugoslav musical folklore. The fact that the same rhythmical patterns can be found in different regions of Yugoslavia was, for Manojlović, an indisputable indicator of the "ethnical unity of our peoples" and their cultural artefacts. ${ }^{69}$

\footnotetext{
${ }^{67}$ Ibid.

${ }^{68}$ Manojlović, Muzičko delo, 25.

${ }^{69}$ Ibid., 24.
} 
Vladimir Đorđević also pointed to the distinctions between the musical folklores of the South Serbian region and other regions, mentioning as examples Vojvodina, Dalmatia and Montenegro. Despite obvious differences, what these regions and other areas had in common was the rhythmical element and the "harmonic features" of melodies that showed persistence as well as resilience to foreign influence. As Đorđević stated, "the foreign elements did not alter the character of our traditional folk music, in the same way as the foreign words did not modify the character of our language." ${ }^{70}$ Milojević stressed the diversity of folk music of Yugoslav regions, which he believed to be the result of cultural, religious, geographical and social as well as climate-related factors. Observing "from the surface level of Yugoslav musical folklore, the extremely dissimilar characteristics of folk tunes of different areas of Yugoslavia are brought to the fore. Šumadija sings differently form Slovenia. Dalmatians had their own type of musical expression divergent from those of Croatian Zagorje or Međimurje, or the Vranje area." ${ }^{71}$ Concerning the music from South Serbia, Milojević was sure that it gave a completely unique accent to Yugoslav musical folklore. Although the "surface layer" manifested numerous contrasting features, Yugoslav musical folklore bore its own specific elements present in the "deeper layers" not perceivable to ordinary people. As Milojević pointed out, the "broader mass" had no sense of the significance of these deeply embedded bonds, despite the fact they are the "bearers of our common racial [ethnic] embryo."72

The Serbian music scholars who explored the folklore of Vardar Macedonia never questioned its belonging to the Serbian and Yugoslav cultural space, or felt the need to enter into discussion with Bulgarian scholars, who claimed exactly the opposite. When the collection Balgaro makedonski pesni (Bulgarian Macedonian Songs), collected and prepared by Josif Cheshmedziev, came out in Sofia in 1926, there was no reaction from Belgrade. Interestingly, the Zagreb-based journal of the Association of Musicians of the Kingdom of SCS, Muzičar (Musician) featured a short review of this publication in the special issue dedicated to Bulgarian music, ${ }^{73}$ created as a result of the initiative to bolster the relations among the musicians and music organizations of the two countries. In Božidar Širola's presentation of Czeshmedziev's work, any reference to Bulgarian nature of the collected material was carefully omitted. ${ }^{74}$ Even the title of the collection was not provided in its original form, and the review bore the title "Macedonian folk songs as arranged by Josif Cheshmedziev." Širola praised the undertaking of the young Bulgarian

\footnotetext{
70 Vladimir Đorđević, "Predgovor [Preface]," Srpske narodne melodije (Južna Srbija) (Skopje: Skopsko naučno društvo, 1928), XIII.

${ }^{71}$ Milojević, "O tipu narodnih melodija," 441.

72 Ibid., 442.

73 1928, No. 3.

74 Božidar Širola, "Makedonske pučke popijevke u odradbi Josifa Češmedžijeva [Macedonian folk songs as arranged by Josif Cheshmedziev]," Muzičar 3 (1928): 8-9.
} 
composer, using the opportunity to remind the readers of the explorations of Kosta Manojlović in "Old Serbia and Macedonia," as well as the insights of the "esteemed L. Kuba" concerning the characteristics of South Slavic folk songs. ${ }^{75}$

In the case of Kosta Manojlović, it is worth mentioning that he started intensive collaboration with renowned Bulgarian composer and musicologist Dobri Hristov in 1926, and later also with other Bulgarian musicians and musical organizations. ${ }^{76}$ It was probably as a result of his commitment to the project of South Slavic cultural integration, along with Yugoslav-Bulgarian rapprochement, that he consciously avoided the controversies of the Macedonian Question. Manojlović, as already stated, did not completely abandon the terminology of the Yugoslav political elite, but his interpretations were shaped in accordance with the discourses of Pan-Slavism and South Slavism, which contributed to minimizing the role of ethnical particularities, and put the emphasis on the supranational level (Yugoslav, South Slav). In Manojlovićs writings for the Institute of Balkan Studies in Belgrade after the mid-1930, the supranational perspective was replaced with an even broader stance stressing the importance of cultural transfers and amalgamation in the shaping of Yugoslav folk music, and its positioning in the "Balkan eastern music group." 77 Whether such classification resulted from a change in Manojlovićs views, or he simply conformed to the ideology of the editors and publishers of the book Knjiga o Balkanu (A Book About the Balkans) and their emphasis on the Balkans as a culturally specific and homogenous whole is hard to conclude from the available sources.

While Bulgarian scholars and writers on folk music of Vardar Macedonia were mostly ignored by their Serbian counterparts, this was not the case with other foreign authors who explored this area. For instance, Vladimir Đorđević wrote a short review of Ludvík Kuba's article on Macedonian music (published in Sveta Cecilija), underlining some of his most important insights and findings-that the foreign influences were fruitful for the music of this area, that it has a specific, individual character compared to other areas in Yugoslavia, that the augmented second is deeply integrated in it, and that it should be preserved. Đorđević found that Kuba, with his investigation and results, "contributed nicely to our unexplored musical folklore," for which he was "very grateful." 78 Unlike Đorđević, Manojlović did not express his views on Kuba's work in Vardar Macedonia, nor in other Yugoslav regions, but he did make a reference to his transcriptions of songs from Bosnia and Herzegovina in his book Muzičko delo našeg sela. ${ }^{79}$

\footnotetext{
75 Ibid.

76 See Vesić, Peno, "Kosta P. Manojlović," 20.

77 See Vesić, Konstruisanje srpske muzičke tradicije, 237.

78 Vladimir Đorđević, "Ludvik Kuba. Pučka glazbena umjetnost u Makedoniji (Sveta Cecilija, god. XXI, 1927, sv. 1-2, Zagreb)," Glasnik skopskog naučnog društva. Odeljenje društvenih nauka 3 (1928): 320.

${ }^{79}$ Manojlović, Muzičko delo, 58.
} 
By contrast, Milojević often commented on Kuba’s research emphasizing what he believed was his incompetence, dilettantism and a lack of proper knowledge and skills. Milojević spoke very critically of Kuba's work for the first time in the aforementioned public lecture in Prague. An interesting report on this event was written by Slovenian musician Srečko Koporc and published in the Cerkveni glasbenik (Church Musician) magazine, pointing to, among other things, a complete incongruity in the evaluation of Kuba's work between Bulgarian musicians and scholars and Milojević. ${ }^{80}$ In this respect, we should mention the generally very positive judgment of Kuba's endeavors by leading researchers of folk music in interwar Yugoslavia, such as Božidar Širola and the intellectual circles of Zagreb, as well as the group of musicians and scholars gathered around the magazine Sveta Cecilija. To Koporc's great disappointment, Milojevićs lecture on Serbian musical folklore focused on a narrow set of elements and criticism of Kuba's undertakings, leading him to the conclusion that the Serbian composer and musicologist "proved to be a better musician than scholar," alluding to the illustrations performed by him and his spouse Ivanka. ${ }^{81}$ In a similar vein, Milojević wrote a harsh critique of Kuba's review of Đorđevićs collection of South Serbian tunes for the Prague journal Tempo. ${ }^{82}$ Along with repeating his thoughts on Kuba's incompetence, Milojević underlined his allegedly "politically biased" position and like-mindedness with the propaganda of the Bulgarian political and intellectual elite:

Both in his collection of folk tunes from Macedonia-published by the Hudebni Matice-and on other occasions, Mr. Kuba expressed his opinion that Macedonia is close to Bulgaria with respect to its language and music. Professional music studies of Macedonia will show the character of this music, and the results of these studies will not coincide with the arbitrary, tendentious and dilettante conclusions of Mr. Kuba. But to prove that Mr. Kuba writes in the Czech journal with an obvious political motive, we will mention a few of his sentences: 'The book [...] contains 428 songs, 30 of which are from Old Serbia and the rest are from Macedonia, named Southern Serbia after the end of the WWI. This name was of purely political nature, because Macedonia, due to its language, was always considered a Bulgarian country by all European experts [...]. The book, good on the musical side, is not flawless as regards the language.' Also: 'the tunes should have been called Bulgarian, if they could not be termed Macedonian.' It is interesting to note that the author did

\footnotetext{
${ }^{80}$ Koporc, "O srbski narodni pesmi," 140.

81 Ibid.

${ }^{82}$ M[iloje]. M[ilojević]., “Beleške. Češki muzički časopis Tempo o muzici našeg juga [Notes. Czech music journal Tempo on the music of our South]," Srpski književni glasnik XXX/5 (1930): 391-392.
} 
not have the courage to label the texts as Serbian. The title was chosen in such a manner as if some of us were presenting Carpathian-Russian songs with the following title: Czech folk melodies: Eastern Czech Republic. This would have been impossible for us. ${ }^{83}$

Instead of providing counterarguments to Kuba’s claims, Milojević's conclusion once again aimed at discrediting him as a music ethnographer, asserting that the thesis he presented coincided with the "thesis promoted by the well-organized and subsidized Bulgarian propaganda." 84

Although a very short text and not so informative, Milojevićs review and the general approach of ignoring the Bulgarian aspect among music scholars illustrate the degree to which the Serbian and Yugoslav position on Vardar Macedonia was internalized, leaving no space for critical reevaluation or debate. Any attempt at this was assumed an act of either supporting Bulgarian propaganda activities or questioning the legitimate Serbian and Yugoslav claims. In the cases of Milojević, Đorđević and partly Manojlović, continuity of the prewar stance and interests with respect to folk music research was undeniable, alongside the already mentioned compliance with the interwar Yugoslav political discourse.

\section{Conclusion}

The assumption of unity of the Yugoslav cultural space, including the region of Vardar Macedonia, seems to have been broadly spread and accepted among the Serbian musicians and music scholars active in the interwar period, which is manifested in their discourse and actions. Not only did the elite music circles find Macedonian folk music an integral part of Yugoslav folklore, but they even gave it primacy over the folklore of other regions with respect to the creation of Yugoslav musical art. Such core position of the music of this area was particularly underlined by Manojlović and Milojević, mostly due to its aesthetic qualities. As Manojlović claimed for the folk music of South Serbia, "it holds a central place [in Yugoslavia], because in its heart it maybe already cradles the future Yugoslav genius." ${ }^{85}$ In a similar manner, Milojević thought of the music of this area "as the richest source of our musical nationalism, racially [ethnically] most typical, expressively most intense, inexhaustible source," which he personally "adores." ${ }^{66}$ Serbian scholars' almost unanimous understanding of the value of the musical folklore of Vardar Macedonia was not given an in-depth explanation in any of the published studies,

\footnotetext{
83 Ibid., 392.

${ }^{84}$ Ibidem.

${ }^{85}$ Manojlović, “Muzičke karakteristike," 180.

${ }^{86}$ Milojević, "O tipu narodnih melodija," 446.
} 
or the detailed comparisons with material from other Yugoslav regions. Therefore, it comes as no surprise that their conclusions left researchers familiar with the traditional folk music of different Yugoslav regions astounded. Ludvík Kuba, whose approach to Yugoslav folk music, including the music of Vardar Macedonia, was not under the influence of Yugoslav national and regional policies, observed them with much doubt and reserve. Commenting on the published findings of Kosta Manojlović concerning South Serbia, Kuba had the following comment:

Based on my own experience and familiarity with the material, as well as my comparative research of the music of different Slavic peoples in the Balkans, I cannot put Macedonia before other Yugoslav regions. [...] If I do not give Macedonian songs primacy over other Yugoslav tunes, I have a reason for that, based on my comparative findings. [...] How could the most beautiful and purest sprouts of Yugoslav song emerge in the regions that are not inhabited solely by Slavic peoples, such as Serbia and Bosnia and Herzegovina? In Old Serbia, Serbs are forced to keep up with Albanians, while in Macedonia, although the non-Slavs are a minority, there are many Albanian and Tzintzar enclaves, and the urban areas are populated with Greeks, Turks, Sephardic Jews, and Gypsies. Why would the genius of Yugoslav music of the future look for the substance in which to be reborn in this region? Why would his embryo grow right here?87

Although Kuba's critical assessment was based on empirical evidence including historical, ethnographic and ethnomusicological facts, his understanding of the music of Vardar Macedonia (and the all of South Serbia) was quite remote for that of the Serbian musical elite of the time. There are many possible reasons for that, but the influence of Western European musical modernism and its fascination with exoticism and "primitivism" certainly cannot be denied. Despite the fact that Manojlović, Đorđević and Milojević wanted to base their research on scientific methods, it seems that their composer's voice usually prevailed and had the last say. This phenomenon, together with the tendency of these researchers to strictly adhere to the terminology and cultural policies of the Yugoslav political elite, resulted in ambiguity and vagueness in many of their insights and findings. Furthermore, it explains the lack of interest to reexamine the positions of their predecessors on the one hand, and the need to complement their work in this domain following the logic and perspective they used on the other.

The research of Serbian music scholars in Vardar Macedonia not only reflected the dominant political concepts of the Serbian and Yugoslav elite regarding

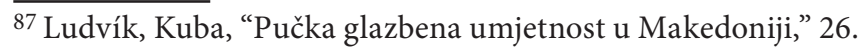


this area, but was also the result of their specific cultural policies. Considering the discrepancy between the research plans and efforts of scholars on the one hand and the state's support on the other, it seems that cultural policy makers of the Kingdom of SCS/Yugoslavia did not find collecting musical folklore a priority in the process of cultural integration of Yugoslavs, including "South Serbians," as well as in the international cultural exchange and promotion of the country. This is evident from their approach to individual research projects, as well as projects under the patronage of certain cultural institutions (museums), particularly during the 1920s. The lack of financial support from the state led to cancellation of research work, its postponing or overall reduction in its design, as well as different problems in the functioning of the folk music departments of the central ethnographic museums. Contrary to the claims of influential Bulgarian figures from the world of music at the time, the Yugoslav state did not intend nor ever gave "two million dinars" 88 for the purpose of researching the musical folklore of South Serbia. This situation did not profoundly change in the 1930s despite advances that were made in the representation of Yugoslav musical folklore abroad through the support of performances and tours of folk or other ensembles since the mid-1930s. Probably the new orientation in Yugoslav foreign policy in that period, specifically the rapprochement with Bulgaria and the signing of the Treaty of Eternal Friendship in $1937,{ }^{89}$ contributed to a great extent to such circumstances. Since folk music research in Vardar Macedonia could stir up the longstanding disputes between the two countries and provoke further controversies, it could be assumed that the status quo in this domain seemed as the most convenient solution. Still, a more in-depth examination of the internal and foreign cultural policies of the late 1930s and early 1940s should be conducted to clarify the role of certain factors in the process of collecting the musical folklore of Vardar Macedonia and other Yugoslav regions.

\footnotetext{
${ }^{88} \mathrm{~A}$ [ndrei]. P. Bersenev, "Voenoto-muzikalnoto delo (statiya chetvrta) [Military music legacy (part four)]," Muzikalen pregled 7 (1926): 3.

${ }^{89}$ More information on this topic can be found in Stefanka Georgieva's paper published in this volume.
} 


\section{Primary sources:}

Archives of Yugoslavia (AJ) (Belgrade): Ministry of Education of the Kingdom of Yugoslavia

Digital National Library of Serbia: http:// www.digitalna.nb.rs/
Digital Repository of the Svetozar Marković University Library: http://www.unilib.rs/ sadrzaji/digitalna-biblioteka/

Digital Library of Slovenia: http://www.dlib.si/ Old Croatian Journals (Portal of Digitized Journals): http://dnc.nsk.hr/Journals/

\section{References:}

Antić, Dejan D. "Političke prilike i srpski narod u Vardarskoj Makedoniji (1903-1912)." PhD diss., Faculty of Philosophy of the University of Niš, 2017. [Orig. in Serbian Cyrillic]

Atanasovski, Srđan. "Stevan Stojanović Mokranjac and Producing the Image of Serbian Folk-Song: Garlands from 'Old Serbia' as a Form of Musical Travelogue," Muzikološki zbornik 1 (2014): 75-90.

Atanasovski, Srđan. "Kosta P. Manojlović and Narratives on 'Southern Serbia.' In Kosta P. Manojlović (1890-1949) and the Idea of Slavic and Balkan Cultural Unification, edited by Vesna Peno, Ivana Vesić, Aleksandar Vasić, 109-126. Belgrade: Institute of Musicology SASA, 2017.

Atanasovski, Srđan. Mapiranje Stare Srbije. Stopama putopisaca, tragom narodne pesme. Belgrade: Biblioteka XX vek, 2017.

Avramovski, Živko (Ed.). Jugoslovensko-bugarski odnosi u XX veku. Vol. 1. Belgrade: Institut za savremenu istoriju, Narodna knjiga, 1980.

Avramovski, Živko (Ed.). Jugoslovenskobugarski odnosi u XX veku. Vol. 2. Belgrade: Institut za savremenu istoriju, Narodna knjiga, 1982.
Bersenev, A[ndrei]. P. "Voenoto-muzikalnoto delo (statiya chetvrta)." Muzikalen pregled 7 (1926): 3. [Orig. in Bulgarian Cyrillic]

Bogetić, Dragan, Kovačević, Slobodanka. Hronologija jugoslovensko-bugarskih odnosa 1878-2003. Belgrade: Jugoistok XXI, Centar za evro-balkansku saradnju, 2003.

Božić, Sofija. "Makedonija kao sporno pitanje između Srpske kraljevske akademije i Bugarske akademije nauka 1913.” In Balkanski ratovi 1912-1913: nova viđenja i tumačenja, edited by Srđan Rudić, Miljan Milkić, 381-392. Belgrade: Istorijski institut, Institut za strategijska istraživanja, 2013. [Orig. in Serbian Cyrillic]

"Danas se svečano otvara nova zgrada Narodnog pozorišta Kralja Aleksandra I." Vreme (October 27, 1927): 4. [Orig. in Serbian Cyrillic]

Dević, Dragoslav. "Sakupljači narodnih melodija u Srbiji i njihove zbirke." Glasnik Etnografskog muzeja 22-23 (1960): 99-122. [Orig. in Serbian Cyrillic]

Dević, Dragoslav, "Miloje Milojević, melograf i etnomuzikolog." In Miloje Milojević, Narodne pesme i igre Kosova $i$ Metohije, edited by Dragoslav Dević, 9-24. Belgrade: Zavod za udžbenika i nastavna sredstva, Karić fondacija, 2004. [Orig. in Serbian Cyrillic] 
Đorđević, Vladimir. "Ludvik Kuba. Pučka glazbena umjetnost u Makedoniji (Sveta Cecilija, god. XXI, 1927, sv. 1-2, Zagreb)." Glasnik skopskog naučnog društva. Odeljenje društvenih nauka 3 (1928): 320. [Orig. in Serbian Cyrillic]

Đorđević, Vladimir. "Predgovor.” Srpske narodne melodije (Južna Srbija). Skopje: Skopsko naučno društvo, 1928. XIII-XVIII. [Orig. in Serbian Cyrillic]

"G. Vladimir Ćorović o predavanjima Kolarčevog univerziteta po Južnoj Srbiji." Vreme (February 15, 1928): 4. [Orig. in Serbian Cyrillic]

Golubović, Vidosava. Letopis kulturnog života, 1919-1925: Vreme, Politika, Pravda. Belgrade, Novi Sad: Institut za književnost i umetnost, Matica srpska, 1989. [Orig. in Serbian Cyrillic]

Hadži-Vasiljević, Jovan. "Prilike pod kojima je postalo Društvo Sv. Save i njegov rad od postanka do sada." Bratstvo XVIII (1924): 1-14. [Orig. in Serbian Cyrillic]

"Izveštaj o radu Narodnog ženskog saveza Kraljevine SHS u 1924-25." Ženski pokret 8 (1925): 274-285. [Orig. in Serbian Cyrillic]

Jagodić, Miloš. "Planovi o politici Srbije prema Staroj Srbiji i Makedoniji (1878-1885)." Istorijski časopis LX (2011): 435-460. [Orig. in Serbian Cyrillic]

Jovanović, Vladan. "Demografske odlike Vardarske banovine i problemi samoidentifikacije." Etnoantropološki problemi 1 (2012): 563-584. [Orig. in Serbian Cyrillic]

Jovanović, Vladan. Jugoslovenska država i Južna Srbija 1918-1929. Makedonija, Sandžak i Kosovo i Metohija u Kraljevini SHS. Belgrade: Institut za noviju istoriju Srbije, 2002.
“Kolarčev univerzitet u Južnoj Srbiji.” Vreme (February 15, 1928): 3. [Orig. in Serbian Cyrillic]

Koporc, Srečko. "O srbski narodni pesmi." Cerkveni glasbenik 9/10 (1929): 139-140.

Krstić, Petar. "Srpske narodne melodije (Južna Srbija). Skoplje, 1928." Pravda (January 27, 1928): 7. [Orig. in Serbian Cyrillic]

Kršić, Jovan. "Ludvik Kuba u Makedoniji (jedan razgovor).” Nova Evropa 1 (1926): 19-23.

Kuba, Ludvík. "Pučka glazbena umjetnost u Makedoniji." Sveta Cecilija 1-2 (1927): 25-27, 76-81.

Lajić Mihajlović, Danka. “Trag muzike urezan u vosku: kolekcija fonografskih snimaka iz Muzikološkog instituta SANU." Muzikologija 23 (2017): 239-258. [Orig. in Serbian Cyrillic]

M[iloje]. M[ilojević]., "Beleške. Češki muzički časopis Tempo o muzici našeg juga." Srpski književni glasnik XXX/5 (1930): 391-392. [Orig. in Serbian Cyrillic]

Majdanac, Boro, Radojčić, Milena (Eds.). Akademsko pevačko društvo Obilić 18841941: dokumenti, sećanja, komentari. Belgrade: Istorijski arhiv Beograda, 2005. [Orig. in Serbian Cyrillic]

Manojlović, Kosta. "Muzičke karakteristike našega Juga.” Sveta Cecilija 5-6 (1925): 138-144, 174-180.

Manojlović, Kosta. Muzičko delo našeg sela. Belgrade: Štamparija Tucović, 1929. [Orig. in Serbian Cyrillic]

Milanović, Biljana. "Stevan Stojanović Mokranjac i aspekti etniciteta i nacionalizma." In Mokranjcu na dar, edited by Ivana Perković Radak, Tijana Popović Mlađenović, 33-53. Belgrade: Fakultet muzičke umetnosti, 2006. [Orig. in Serbian Cyrillic] 
Milojević, Miloje. "Beleške. Češki muzički časopis Tempo o muzici našeg juga." Srpski književni glasnik XXX/5 (1930): 391-392. [Orig. in Serbian Cyrillic]

Milojević, Miloje. "Muzički pregled. Za spas naše muzičke kulture. Povodom muzičkog festivala u Frankfurtu na Majni." Srpski književni glasnik XXI/4 (1927): 296-301. [Orig. in Serbian Cyrillic]

Milojević, Miloje. "O tipu narodnih melodija Južne Srbije i o njihovoj izražajnoj snazi." Srpski književni glasnik LVI/6 (1939): 441-446. [Orig. in Serbian Cyrillic]

Nedeljković, Slaviša. "Delovanje Odbora za škole i učitelje u srpskim oblastima u Makedoniji od 1868. do 1876." Vardarski zbornik 8 (2011): 283-305. [Orig. in Serbian Cyrillic]

"Pitanje o broju fakulteta (memoar komisije)." Prosvetni glasnik 2 (1928): 181-210. [Orig. in Serbian Cyrillic]

Roudometof, Victor. Collective Memory, National Identity, and Ethnic Conflict: Greece, Bulgaria, and the Macedonian Question. Praeger Publishers, 2002.

Roudometof, Victor (Ed.). The Macedonian Question: Culture, Historiography, Politics. East European Monographs, 2000.

Sotirović, Vladislav B. "Macedonia between Greek, Bulgarian, Albanian, and Serbian National Aspirations, 1870-1912." Serbian Studies: Journal of the North American Society for Serbian Studies 23/1 (2009): 17-40.

"Srpske narodne melodije najinteresantnije su u Evropi. Razgovor sa g. Ludvikom Kubom, pred njegov put u Južnu Srbiju." Vreme (July 17, 1925): 4. [Orig. in Serbian Cyrillic]
Širola, Božidar, Gavazzi, Milovan. "Muzikološki rad Etnografskog muzeja u Zagrebu od osnutka do konca g. 1929." Narodna starina 25 (1931): 3-80.

Širola, Božidar. "Ludvik Kuba. O 60-godišnjici njegova života." Sveta Cecilija 4 (1923): 97-98.

Širola, Božidar. "Makedonske pučke popijevke u odradbi Josifa Češmedžijeva." Muzičar 3 (1928): 8-9.

Trgovčević, Ljubinka. Naučnici Srbije i stvaranje jugoslovenske države 1914-1920. Belgrade: Narodna knjiga, Srpska književna zadruga, 1986. [Orig. in Serbian Cyrillic]

Vesić, Ivana. "Konstruisanje srpske muzičke tradicije u periodu između dva svetska rata: uticaj ideoloških podela u srpskoj političkoj i intelektualnoj eliti." PhD diss., Faculty of Philosophy of the University of Belgrade, 2016. [Orig. in Serbian Cyrillic]

Vesić, Ivana. Konstruisanje srpske muzičke tradicije u periodu izmedu dva svetska rata. Belgrade: Muzikološki institut SANU, 2018. [Orig. in Serbian Cyrillic]

Vesić, Ivana, Peno, Vesna. "Kosta P. Manojlović: A Portrait of the Artist and Intellectual in Turbulent Times." In Kosta P. Manojlović (1890-1949) and the Idea of Slavic and Balkan Cultural Unification, edited by Vesna Peno, Ivana Vesić, Aleksandar Vasić, 13-25. Belgrade: Institute of Musicology SASA, 2017.

Vinaver, Stanislav. "Narod u punom jeku stvaranja. Otkrića i slutnje g. Koste Manojlovića." Vreme (October 2, 1924): 6. [Orig. in Serbian Cyrillic] 


\title{
Before and after the "Treaty of Eternal Friendship." Musical and cultural contacts between Bulgaria and Yugoslavia in the 1930s (an attempt at typology)
}

\author{
Stefanka Georgieva
}

In the complicated and contradictory development of the relations between Bulgaria and Yugoslavia, the 1930s are a period which has steadily drawn the attention of Bulgarian historians. Researchers' interest in this topic has never faded, even during the Cold War, which brought the revelation and publishing of valuable documents from the accessible records of the Bulgarian Academy of Sciences and the Central State Archives in Sofia, from the Archives of Yugoslavia, press materials and others. The exploration of these enormous amounts of historiographic information is a serious trial for any attempt at suggesting a new interpretation of the events of this decade, which are only a tiny fragment of diverging and sometimes mutually exclusive tendencies in the two states' relations, heavily burdened by the consequences of the two Balkan Wars and WWI. In parallel with this, this same period was marked by an unmatched culmination in the history of their relations - the signing of the Treaty of Inviolable Peace and Eternal Friendship (1937), giving an impetus to overcome the status quo and the stagnation, mutual distrust and feud. ${ }^{1}$

The musical and cultural contacts between Bulgaria and Yugoslavia fall into the web of these complicated political processes. This paper aims to follow the dynamics of traditional connections and the establishing of new ones in the context of the resumed political dialogue between the two countries. Based on materials from the periodical press, archival sources and diplomatic correspondence related to the topic, it is an attempt to shed light on their development in order to emphasize the succession and continuity of cultural collaboration, with the participation of distinguished musicians and performers from both countries. The chronological lines of the chosen period are conditional. On the one hand, the tendency of rapprochement through choral exchange remained steady, and on the other, the

1 Krastyo Manchev, Valerian Bistritski, Bulgaria i neynite sasedi (1931-1939). Politicheski i diplomaticheski otnoshenia [Bulgaria and Its Neighbors (1931-1939). Political and Diplomatic Relations] (Sofia: Nauka i izkustvo, 1978), 63-83. 
scope of cooperation expanded through initiatives influenced to different extents by the positive tone in political communication.

Thus, a long-suppressed post-WWI process began to manifest itself as early as the mid-1920s, reviving the long cultural traditions with different centers of the new Kingdom of Serbs, Croats and Slovenes / Yugoslavia-Belgrade, Zagreb and Ljubljana. In March 1929, Belgrade's semiofficial mouthpiece Politika announced "the first mutual visits of cultural figures from both countries." 2 Quite some time before that, however, it had become popular in the Bulgarian and Yugoslav musical press to make initiatives for cooperation between professional music organizations of both countries, publishing reviews of mutual choir visits, as well as information about events in musical life and other similar information. ${ }^{3}$ Through the personal contacts between Yugoslavia's Kosta P. Manojlović and prominent Bulgarian musician Dobri Hristov, the first attempts were made to institutionalize the musical and cultural connections between the First Belgrade Choral Society and the newly created Bulgarian Choral Union (1926), and later also with the South Slav Choral Union (Južnoslovenski pevački savez, SSCU), the largest musical organization in the Kingdom. As early as the first assembly of SSCU delegates (1924), it was confirmed that the organization worked on "integral South Slavic musical thought, which is only a precursor of the integral unity of the Slavic South," rejecting "every tribal and local background" and striving for the formation of "a unique South Slavic musical ideology [...] and unique South Slavic national consciousness!" 4

Apparently influenced by certain political and ideological aspects of the so-called integral Yugoslavism, the SSCU's program declaration initially included not only Serbs, Croats, Slovenes, but also Bulgarians. This way, it reflected Kosta Manojlovićs view of building a unified South Slavic musical and cultural concept, an idea, which he regarded as his mission and which he also promoted among Bulgarian figures of choral music. His call "We come to widely open the door to rapprochement among brotherly peoples, starting with a spiritual basis," published in the Slovo newspaper (1926), gave words to the intense drive for mutual cooperation, regardless of the obstacles and limitations posed by the political situation. ${ }^{5} \mathrm{As}$

\footnotetext{
2 Quoted in Zdravka Micheva, "Balgaro-yugoslavsko kulturno sblizhenie 1933-1940 [BulgarianYugoslav cultural rapprochement 1933-1940]," Istoricheski pregled 3 (1967): 4.

3 One example is the introductory article "Music Bulgaria and Yugoslavia" published in Muzikalen pregled 15-16 (1926): 1-2.

4 Quoted in Biljana Milanović, "The Contribution of Kosta P. Manojlović to the Foundation and Functioning of the Južnoslovenski pevački savez [South Slav Choral Union]," in Kosta P. Manojlović (1890-1949) and the Idea of Slavic and Balkan Cultural Unification, edited by Vesna Peno, Ivana Vesić, Aleksandar Vasić (Belgrade: Institute of Musicology SASA, 2017), 77.

5 Quoted in Dobri Hristov, Muzikalno-teoretichesko i publitsistichesko nasledstvo [Musical, theoretical and publicist heritage]. Volume 2, edited by Venelin Krastev (Sofia: Balgarska akademia na naukite, 1970), 218.
} 
a matter of fact, Manojlović was one of the few Yugoslav intellectuals at that time who publically expressed his view about the need for cultural collaboration with Bulgarians and actively made "efforts to put this strategy into practice." $6 \mathrm{He}$ found a fellow Pan-Slavist in Dobri Hristov, who wrote to him on the occasion of the First Yugoslav Musical Exhibition in Belgrade (1926): "We hope that the beginning of the spiritual community on the ground of the most supreme art-music, will echo deeply in the hearts of our political leaders, to welcome that beautiful day of the creation of a united and powerful Yugoslav state." 7 That is why it is not by chance that the First Belgrade Choral Society chose Dobri Hristov as its honorary member, recognizing not only his creative work, but also his support for the idea of South Slavic and Pan-Slavic cultural solidarity.

The chronology of these Bulgarian-Yugoslav musical contacts, of which there is information in the press and in the personal archives of Bulgarian musical figures, has yet to be thoroughly explored. They differed in intensity and were mainly realized through personal creative initiatives. Nevertheless, some documents show that from the middle of the 1920s the musical diplomacy anticipated, and in some cases was ahead of the process of thawing of political relations between the two neighboring countries. ${ }^{8}$ In fact, attempts at cooperation between the choral unions were often thwarted due to different circumstances resulting from the cold interstate relations. There were instances of this both on the Bulgarian and on the Yugoslav part. ${ }^{9}$ Hesitations of Bulgarian choral musicians as to joining Manojlovićs "grand idea" of a South Slavic cultural union were secretly reflected in the resolution of the Second Congress of the Bulgarian Choral Union (1928), where there were tactful hints to disputes between the choral centers in Belgrade and Zagreb. Regardless of this, the musical exchange did not stop, but there was an apparent differentiation in contacts, where connections between Bulgarian, Croatian and Slovenian musicians, societies and others were more active and predominated over those with the neighboring Serbian musical institutions. ${ }^{10}$

\footnotetext{
6 Ivana Vesić, Vesna Peno, "Kosta P. Manojlović: A Portrait of the Artist and Intellectual in Turbulent Times," in Kosta P. Manojlović (1890-1949) and the Idea of Slavic and Balkan Cultural Unification, edited by Vesna Peno, Ivana Vesić, Aleksandar Vasić (Belgrade: Institute of Musicology SASA, 2017), 13.

7 Dobri Hristov's letter to Kosta P. Manojlović, Sofia, April 3, 1926. Quoted in Milanović, “The Contribution of Kosta P. Manojlović," 78.

8 See Stefanka Georgieva, "The Idea of South Slavic Unity among Bulgarian Musicians and Intellectuals in the Interwar Period," in Kosta P. Manojlović (1890-1949) and the Idea of Slavic and Balkan Cultural Unification, edited by Vesna Peno, Ivana Vesić, Aleksandar Vasić (Belgrade: Institute of Musicology SASA, 2017), 42, 54-55.

9 Vesić, Peno, "Kosta P. Manojlović," 20.

10 Agapia Balareva. Horovoto delo v Bulgaria ot sredata na 19 vek do 1944 godina. (Prilozhenia. Chuzhdi horove v Bulgaria. Balgarski horove v chuzhbina) [Choral Work in Bulgaria from the
} 
Since the late 1920s and the early 1930s, the relations in politics and music have been dominated by the discussion about the "Macedonian folklore" - the most burning issue in Bulgarian-Serbian scientific arguments in the field of music. On the Bulgarian side, it had its own center, the Macedonian Scientific Institute (1923-1947, restored in 1990), which was created to study the history, ethnography, language and economic life of Macedonia, to gather materials about the national liberation struggle of Macedonian Bulgarians, and to introduce all of these to scientific and cultural circles in Bulgaria and abroad. It brought together scientists and public figures with Macedonian roots, and attracted foreign collaborators, specialists on the political and cultural aspects of the so-called Macedonian Question as regular and honorary members of the Institute. ${ }^{11}$ Among them was Ludvík Kuba (1863-1956), a Czech writer, artist and ethnologist, professor at the Academy of Fine Arts in Prague, who released an impressive collection of Slavic folk songs in his series Slovanstvo ve svých zpèvech (Slavs in Their Songs) (1884-1928). ${ }^{12}$

One of the books in his collection, featured 31 Macedonian folk songs from all regions of this South Slavic province divided among three countries after WWI. In the preface to this edition, he shared his views about the Bulgarian roots of Macedonian speech and the common metric and tonal characteristics of the folk melodies. This provoked a heated discussion between Bulgarian and Serbian scientists with strong political overtones. ${ }^{13}$ What stood out on the Bulgarian side was the position of Dobri Hristov, until then an unrivaled theoretician of our folk music, who laid the scholarly foundations for the studying of its rhythmic and metric features. ${ }^{14}$ However, he was not just an "office scientist," but also "a transcriber of tunes [...] who was always among the people at the time." ${ }^{15}$ Among

Middle of the $19^{\text {th }}$ Century to 1944. (Appendices. Foreign Choirs in Bulgaria. Bulgarian Choirs Abroad)] (Sofia: Balgarska akademia na naukite, 1992), 166, 213-216.

${ }^{11}$ Until WWII, the Institute had 110 scientists as members. Their studies were published in the Macedonian Review Magazine. See "Kratka istoria na Makedonskia nauchen Institut [A brief history of the Macedonian Scientific Institute]," accessed January 25, 2019, http://www.mni.bg/2013/06/ kratka-istoria-na-makedonskia-nauchen.html.

${ }^{12}$ Ludík Kuba, Slovanstvo ve svỳch zpevĕch. Sborník písni všech slovanskỳch nàrodů s pưvodními texty a českỳmi překlady. (Kniha XIV. Díl V. Písne juhoslovanské. Čast VIII. Písne Makedonské) [Slavs in Their Songs. A Collection of Songs of all Slavic Nations with Original Lyrics and Czech Translations (Book XIV, Part V Songs of Yugoslavia, Section VIII Macedonian songs] (Prague: self-published, 1928).

${ }^{13}$ See Vasil Stoin, "Nauka ili politika [Science or politics]," Muzikalen zhivot 6 (1928): 2-5.

14 These are the studies: "Ritmichnite osnovi na narodnata ni muzika [The rhythmic foundations of our folk music]," Sbornik s narodni umotvorenia 27 (1913): 1-48, and "Tehnicheskiyat stroezh na balgarskata narodna muzika (ritmika, metrika, tonalni i harmonichni osobenosti) [Technical structure of Bulgarian folk music (rhythmic, metric, harmonic and tonal characteristics)]," in Dobri Hristov, Muzikalno-teoretichesko, 63-125.

${ }^{15}$ Nikolay Kaufman, "Dobri Hristov - praktikat [Dobri Hristov-a man of practice]," in Dobri Hristov i balgarskiyat 20 vek, edited by Elena Toncheva (Sofia: Institut za izkustvoznanie, 2005), 63. 
the working materials preserved in his archive is his own collection of tunes from different areas and ethnic regions, including Bitola, Prilep, Štip, Kostur (Kastoria, now Greece), Struga, Galičnik and others. 16 These prove his continuous interest in "the Macedonian folk song, which is his great love." 17

In 1931, Hristov published a collection of 66 folk songs of Macedonian Bulgarians with an introductory study, where he formulated the main aim of the edition: to present in "a cultural and historical document the true national image of Macedonian Bulgarians through their tunes, exposed consciously or unconsciously to changes today, distancing them from their original kind." 18 The records of folk tunes included in the collection were provided as "proof outlining the general Bulgarian musical folk style, in which the songs of Macedonian Bulgarians are treated as its substantial part." ${ }^{19}$ In his comment, Hristov retained the objective scientific approach and did not allow himself to mention questions concerning the involvement of folklore with political and manipulative goals in the dispute between Bulgarian and Serbian ethnomusicologists. ${ }^{20}$ But the question remains how his position on "Macedonian folklore" affected his relations with his colleague Manojlović, for which only scarce documents are preserved in the archive of the Bulgarian musician.

In the beginning of the 1930s, Bulgaria's dialogue with its neighbors became more and more important to its foreign policy. However, the rapprochement with Yugoslavia turned out not to be so simple, because of a true Gordian knot of political, territorial, economic, ethnic, ecclesiastical and other controversial issues. Regardless of the attempts and efforts at reconciliation, the mutual distrust and the frequent provocations on the borders remained although the manifestations of the shared interest in improving the relations between the two countries were already a fact. A breakthrough came in 1933 when it "also became the policy of the governing circles in Yugoslavia and Bulgaria. [...] Belgrade's and Sofia's motives

\footnotetext{
16 Kristina Yapova, Arhivat na Dobri Hristov. Katalog. (Razdel II. 10. Rabotni materiali. II.10.1. Zapisi na muzikalen folklor) [Dobri Hristov's Archive. Catalogue. (Section II. 10. Working materials. II.10.1. Folk music recordings)] (Sofia: Matom, 2002), 73-79.

17 Kaufman, "Dobri Hristov - praktikat," 64.

${ }^{18}$ Lidia Litova-Nikolova, "Dobri Hristov i sbornikat mu '66 narodni pesni na makedonskite balgari [Dobri Hristov and his collection "66 Folk Songs of Macedonian Bulgarians"]," in Dobri Hristov $i$ balgarskiyat 20 vek, edited by Elena Toncheva (Sofia: Institut za izkustvoznanie, 2005), 73.

19 Ibid.

20 Dobri Hristov, "Makedonskite balgarski pesni [Macedonian Bulgarian songs]," in Dobri Hristov, Muzikalno-teoretichesko, 131-154. In the 1920s, this aspect was commented on by another Bulgarian ethnomusicologist, Vasil Stoin, in the abovementioned article "Nauka ili politika," 2-5. See also the opinion of Svetlana Zaharieva, "Muzikalno-folklorno izsledvane i nazionalisam. Pogled kam minaloto s missal za nastojashteto [Musical folklore research and nationalism. A look at the past with view for the present]," Bulgarian musicology 1 (1995): 19-38.
} 
were different, and so were their foreign policy directions and aims." ${ }^{21}$ Although covertly and mostly on the Yugoslav side, plans with a more distant prospect were considered: creating a country bordering two seas, the Adriatic and the Black Sea-a country that would unite all South Slavic peoples. ${ }^{22}$ Suggestions for the rapprochement process also came from great powers, which had their own plans, claims and spheres of influence on the Balkans.

Two significant meetings between Tsar Boris III of Bulgaria and King Alexander I of Yugoslavia in Belgrade and Varna in the autumn of 1933 opened the way for dialogue between the two countries. Both of them belonged to a new generation of politicians who witnessed and participated first-hand in the events on the fronts of the Balkan Wars and WWI. Their contacts, preceding the signing of the Balkan Pact, caused suspicion in the other Balkan neighbors (Romania, Greece, Turkey). ${ }^{23}$ In this unstable situation in international relations, Bulgaria changed governments with a shift in political orientation, but the course toward communication with Yugoslavia was supported. Of course, it had its opponents, particularly in the circles of the Internal Macedonian Revolutionary Organization (IMRO), whose armed actions frequently provoked tensions with the neighbors. In 1934, both countries went through turbulent events. For Bulgaria this was the May coup d'état, which established total control of Tsar Boris III over the country, and for Yugoslavia it was the assassination of King Alexander I in Marseille, which broadly echoed on the international scale.

However, the rapprochement process did not stop, and entered a new stage after 1935, one marked by the activity of two other political figures-Yugoslav Prime Minister Milan Stojadinović (1888-1961) and Georgi Kyoseivanov (1884-1960), a former Bulgarian Ambassador to Belgrade (1933-1934) and later on Prime Minister of Bulgaria. They made many skillful diplomatic moves and held numerous bilateral meetings with the allies from the Balkan Pact, maneuvering between the interests of the great powers, as well as isolating the internal opponents of rapprochement. This cause gave them the opportunity to gain popularity with a large part of their populations, which supported its successful realization. ${ }^{24}$ As a result of this, they achieved what was probably the most important: the arguments and mutual claims after WWI were left behind. ${ }^{25}$

Under these circumstances, another process developed as early as the beginning of the 1930s, where the participants were rarely in the focus of public attention.

\footnotetext{
${ }^{21}$ Manchev, Bistritsky, Bulgaria i neynite sasedi (1931-1939), 63, 67-68, 77.

22 Ibid., 69.

${ }^{23}$ Krastyo Manchev, Istoria na balkanskite narodi. Vol. 3 (1918-1945) (Sofia: Paradigma, 2008), 240-244.

${ }^{24}$ Manchev, Istoria na balkanskite narodi, 237-240.

${ }^{25}$ Manchev, Bistritsky, Bulgaria i neynite sasedi (1931-1939), 77.
} 
Based on an understanding that cultural exchange was necessary before the interstate relations can improve, a group of public figures from both countries "began to intensively promote the idea of creating an organization for cultural cooperation and rapprochement." ${ }^{26}$ For its realization, they had to overcome not only the opposition of the pro-German politicians, but also the skepticism and distrust of the part of intellectuals in both countries who were extremely nationalistically predisposed. The first steps were made alongside the establishment of the Yugoslav-Bulgarian Rapprochement Club (September 20, 1933) and the Yugoslav-Bulgarian League (September 24, 1933) in Belgrade, and the Bulgarian-Yugoslav Society (September $29,1933)$ in Sofia. Branches with cultural and student sections were opened in Zagreb, ${ }^{27}$ Ljubljana ${ }^{28}$ and in various Bulgarian cities. The organizations issued a one-time journal Bulgarian-Yugoslav Review (Sofia, 1934; Belgrade, 1935), ${ }^{29}$ and encouraged mutual visits of writers, actors, artists, opera singers and others. ${ }^{30}$ The guest performances of representative Bulgarian and Yugoslav groups became more frequent: the Gusla Choir, the Rodna pesen Choir, the Choir of the Sofia Faculty of Theology, the Obilić Academic Choral Society, the Stanković Choir (Belgrade), the Glasbena matica Choir (Ljubljana), the Cyril and Methodius Choir (Zagreb) and others, which maintained and enriched the tradition from the 1920s. ${ }^{31}$ Reports on their concerts commonly reflected on Slavic topics. ${ }^{32}$

In the time of the restless internal political situation in Bulgaria and Yugoslavia in 1934, the Bulgarian Ambassador in Belgrade was Dimo Kazasov (1886-1980), one of the most controversial figures in Bulgarian public life in the interwar years. He is said to have been a skillful demagogue whose biography is a true labyrinth of pragmatism and adaptation moves. A fierce opponent of the

\footnotetext{
${ }^{26}$ Micheva, "Balgaro-yugoslavsko kulturno sblizhenie," 8.

27 On the activities of the Bulgarian-Yugoslav League in Zagreb, see "Edma balgarska sedmiza v Zagreb [A Bulgarian week in Zagreb]," Slavjanski vesti 8 (1936): 5.

${ }^{28}$ See Afrodita Aleksieva et al. (Eds.), Balgaro-balkanski kulturni vzaimootnoshenia. 1878-1944 [Bulgarian-Balkan Cultural Relations 1878-1944] (Sofia: Bulgarian Academy of Sciences, 1986), 114.

${ }^{29}$ Micheva, "Balgaro-yugoslavsko kulturno sblizhenie," 14.

${ }^{30}$ Reviews of these guest performances from 1934 onward were regularly published in the Zlatorog magazine.

${ }^{31}$ Micheva, "Balgaro-yugoslavsko kulturno sblizhenie," 10-11, 19.

32 See Nikola Stanev, "Sblizhenie mezhdu Yugoslavia i Bulgaria [Rapprochement between Yugoslavia and Bulgaria]," Slavyanski glas 3-4 (1933): 7; "Yugoslavyano-balgarski klub [The Yugoslav-Bulgarian club]," Slavyanski glas 3-4 (1933) 106-108; "Koncerti. Gostovanje bugarskog hora studenata teološkog fakulteta iz Sofije u Jugoslaviji [Concerts. The guest performance of the Bulgarian choir of Faculty of Theology students from Sofia in Yugoslavia]," Cirilometodski vjesnik 3 (1934): 29-30; "Iz vjesti. Treći koncert Zagrebačke filharmonije [From the news. Third concert of the Zagreb Philharmonics]," Sv. Cecilija 1 (1935): 18; "Tarzhestvo na rodnata ni pesen. Hor 'Rodina' v Yugoslavia [A celebration of our native song. "Homeland" Choir in Yugoslavia]," Literaturen glas 269 (1935): 2.
} 
monarchy, Kazasov established and led his own political circle Zveno (1927-1934). ${ }^{33}$ But why did Tsar Boris III entrust him with the diplomatic position in Belgrade when he openly displayed hostility to the monarchical order? In one such situation - a demonstrative breach of protocol-his mission in Belgrade quickly came to an end. But other reasons prevailed for him to be appointed to this post. One of them was probably that Kazasov knew the internal issues of the neighboring country very well. Well-known was his activity to establish Bulgarian-Yugoslav cultural contacts, a cause to which he dedicated himself with a consistency unmatched by the twists in his political biography.

A more interesting fact is that Kazasov's political career went hand in hand with active literary and journalistic engagement. A large part of his texts was devoted to pressing social events, but Kazasov had a huge amount of written works, which includes about 30 books. One of them was Today's Yugoslavia (1938), published shortly after his brief diplomatic posting in Belgrade. The book was written "to familiarize the Bulgarian reader with the closest Balkan country in origin and fate-Yugoslavia. [...] to find out, based on facts, what blessed the grounds for cooperation, and what a great future of shared prosperity lies before the joint efforts of Bulgarians, Serbs, Croats and Slovenes, who share the same origin and soul." ${ }^{34}$ At the same time, Kazasov was the permanent chairman of the Union of Bulgarian-Yugoslav Societies from 1932 to 1941. His activity in this capacity was a clear illustration of the parallel processes of rapprochement in the spheres of political and cultural communication. The joint initiatives were reflected in the Bulgarian press in numerous articles, whose tone was predominantly positive and supportive. Here, we come to a curious fact. Even before the Treaty of Eternal Friendship was signed, the managers of the Belgrade and Sofia National Theaters exchanged suggestions on decorating the other country's actors with medals, which their monarchs approved. ${ }^{35}$

\footnotetext{
${ }^{33}$ Dimo Kazasov participated in three coups-in 1923, 1934 and 1944. After that he served as the Minister of Propaganda, Information and Arts (1944-1947), managing director of publishing houses, printing companies and in the printed production trade (1950-1953). See Ilcho Dimitrov, Minaloto, koeto beshe blizko, a stava vse po-dalechno. Sreshti i razgovori [The past, which was close, but is becoming more and more distant. Meetings and conversations] (Sofia: Universitetsko izdatelstvo "Sv. Kliment Ohridski," 1992); Borislav Gardev, "Dimo Kazasov - talantliviyat demagog [Dimo Kazasov—the talented demagogue]," accessed February 4, 2019, https://liternet.bg/publish4/ bgyrdev/podir/01_12.htm.

${ }^{34}$ Dimo Kazasov, Dneshna Yugoslavia [Today's Yugoslavia] (Sofia: without publishing details, 1938), 3. He wrote only short notes about his diplomatic mission in Yugoslavia, spread throughout his numerous publications. See Dimo Kazasov, "Iskri ot burni godini [Fragments from lively years]," in Izbrani proizvedenia. With a foreword by the author, editor and compiler Stefan Zhelev (Sofia: Otechestven front, 1987), 419-420.

${ }^{35}$ Aleksieva et al. (Eds.), Balgaro-balkanski kulturni vzaimootnoshenia, 172.
} 
There were not any musicians among the founders of the Union of Bulgarian-Yugoslav Societies. ${ }^{36}$ The names of music critic Ivan Kamburov, Dimitar Hadzhigeorgiev, president of the Academy of Music, and Andrey Stoyanov, piano teacher and a member of the Bulgarian Academy of Sciences, were mentioned in a letter from 1935, which the editorial board of the World Encyclopedia in Belgrade sent them with an invitation to participate as collaborators in the publication. ${ }^{37}$ The press published messages about the connections of Bulgarian scientists with the Institute of Balkan Studies established in Belgrade (1934), as well as information about their publications included in the magazine La revue internationale des Etudes balkaniques and the series Knjiga o Balkanu (A Book About the Balkans). ${ }^{38}$ This way, along with the foundation of the Bulgarian-Yugoslav societies, bilateral contacts also became more active on the level of high science. The business correspondence between the managers of the Sofia National Opera and the Belgrade National Theater reveals another perspective of the cultural relations, related to guest performances of opera singers, negotiating new theater performances and other aspects. ${ }^{39}$ These specific areas of bilateral cooperation are yet to be more thoroughly researched.

The musical exchanges in the 1930s included a new generation of Bulgarian musicians-instrumentalists and conductors, singers of the Sofia opera, symphony orchestras, chamber music ensembles and others. In 1933, composers founded the Contemporary Music Society, which also actively assisted in the emergence of new forms and content in the contacts with the Yugoslav musical culture. The series of visits of representative Bulgarian musical groups opened with a concert by the Sofia Academy Symphony Orchestra in Belgrade in May 1934. The conductor was Sasha Popov (1899-1976), a virtuoso violinist with a brilliant international career, who entered this line of work to establish himself as a founder of symphonic performing arts in Bulgaria. ${ }^{40}$

These Bulgarian visits preceded the emergence of another course in the musical exchange between the two neighboring countries, which developed in the next stage, the period 1937-1940, and exceeded its borders, marking a culmination of cultural contacts of its kind, not only in the decade in question but the entire previous century. It is undoubtedly a reflection of the favorable development in bilateral relations following the Treaty of Eternal Friendship, which the two prime ministers, Georgi Kyoseivanov and Milan Stojadinović, signed in Belgrade on January 24, 1937. In its essence, the agreement turned out to be a concise declaration, with no

\footnotetext{
${ }^{36}$ See Annual report of the Bulgarian-Yugoslav Society 1933-1934. Without publishing details; Annual report of the Bulgarian-Yugoslav Society 1934-1935. Without publishing details.

${ }^{37}$ Aleksieva et al. (Eds.), Balgaro-balkanski kulturni vzaimootnoshenia, 55-57.

38 Ibid., 59, 64, and others; Micheva, "Balgaro-yugoslavsko kulturno sblizhenie," 15-16.

${ }^{39}$ Aleksieva et al. (Eds.), Balgaro-balkanski kulturni vzaimootnoshenia, 146-147, 155, 166.

40 The program was not announced in the press. The same year, Sasha Popov founded the Tsar's Military Symphony Orchestra, a predecessor of the Sofia Philharmonics, which he led from 1947 to 1956.
} 
other provisions or appendices to specify the mutual obligations and rights of the parties. ${ }^{41}$ It did not give answers to the most important questions in connection to the relations between Bulgaria and Yugoslavia: what their aims were, what they had in common, and what their national interests were. ${ }^{42}$ Guessing on all of these raised suspicion in the allies, but especially in the neighboring countries. The distrust toward the Bulgarian-Yugoslav "eternal friendship" grew, accelerated also by the political situation, which became more and more complicated, with the looming outbreak of a new military conflict on the European continent. According to Krastyo Manchev, one of the authoritative researchers of this historical event, "the treaty was not just a platonic outpouring of friendly sentiments." ${ }^{43}$ In fact, not only him, but also other Bulgarian historians assumed that there was a secret agreement behind it, based around the desire of both countries to have direct access to the Aegean Sea. However, these guesses have not been confirmed yet by documents from diplomatic archives. ${ }^{44}$ For Bulgaria, the Treaty was an important act, realizing its desire for neighborliness with the Kingdom of Yugoslavia, and a step toward the overcoming its international isolation after WWI.

As a matter of fact, there is only one area where the assessments of historians are amazingly unanimous-cultural cooperation between the two countries. Even if we presume that the political propaganda around the agreement had its impact on some of the publications in the Bulgarian and Yugoslav press, the media defining it as "a blessed deed" and "a reliable tool of peace" prevailed. ${ }^{45}$ Famous Bulgarian and Yugoslav artists, writers, actors and musicians joined the cultural events, and their presence was not merely an expression of formal support for the consensus achieved between the states, but participation in making the cultural dialogue with long historical traditions more active. 46

The effects of the Treaty on the musical exchange appeared right after its signing, with a series of symphony and chamber music concerts (Belgrade and

\footnotetext{
${ }^{41}$ Krastyo Manchev, Yugoslavia i mezhdunarodnite otnoshenia na Balkanite 1933-1939 (Sofia: Balgarska akademia na naukite, 1989), 152-165.

42 Manchev, Istoria na balkanskite narodi, 262-272; See also Manchev, Bistritski, Bulgaria i neynite sasedi (1931-1939), 226-227.

${ }^{43}$ Manchev, Istoria na balkanskite narodi, 268.

${ }^{44}$ There were hints about this also by the Yugoslav allies in the Balkan Pact. See Aleksieva et al. (Eds.), Balgaro-balkanski kulturni vzaimootnoshenia, 232-234.

${ }^{45}$ St.[?] Koledarov, "Edno blagosloveno delo [A blessed deed]," Slavjanska beseda 2 (1937): 76-77; "Dogovor za prijatelsto mezdu Balgaria i Yugoslavija [Treaty of friendship between Bulgaria and Yugoslavia]," Slavjanski vesti 1 (1937): 1-2; Nikola Stanev, "Kakvo predstavljavat sdruzenite Balgaria i Yugoslavija [What are the allied Bulgaria and Yugoslavia like]," Slavjanski vesti 12 (1937): 3-4; "Edin siguren instrument na mira. Balgaro-yugoslavskijat dogovor za vechna druzba [A reliable tool of peace. The Bulgarian-Yugoslav treaty of eternal friendship]," Chas 33 (April 19, 1937): 4. On the reviews in the Belgrade newspapers Politika and Pravda, see Micheva, "Balgaro-yugoslavsko kulturno sblizhenie," 24-25.

${ }^{46}$ Micheva, "Balgaro-yugoslavsko kulturno sblizhenie," 23-28.
} 
Sofia, March-April 1937) and multiple guest performances of musicians-singers and instrumentalists - which exceeded in scale the agreement's political aspects. ${ }^{47}$ On March 7, 1937, a concert was performed at the National Theater, "dedicated to Yugoslav music on the occasion of the constitutive congress of the BulgarianYugoslav societies in Bulgaria." The central figures who contributed to its realization were Dimo Kazasov, who gave a talk on "The rapprochement between Bulgarian and Yugoslav peoples," and music critic Ivan Kamburov, who presented, in his own words, "contemporary Yugoslav music, with a special focus" on composers of the "Belgrade group." Nevertheless, the program was thematically heterogeneous. It featured mainly solo and choral works by Davorin Jenko, Stanislav Binički, Jakov Gotovac and Miloje Milojević, but "Pesen" from Petar Konjović's opera Koštana and a String Quartet by Josip Slavenski were also performed. Soloists of the Sofia National Opera, the Kaval Choir and the Avramov Quartet participated. Reports from the event emphasized the presence of a "sophisticated audience"-intellectuals, writers and notable figures. ${ }^{48}$ Letters addressed to the prime ministers of Bulgaria and Yugoslavia were read, and they were proclaimed honorary members of the Slavjanska beseda Society. ${ }^{49}$

Another response to the political "fraternization" was a symphonic concert dedicated to Bulgarian music, which the Belgrade Philharmonics gave one month later (April 3, 1937) in the Grand Hall of the Kolarac People's University ${ }^{50}$ and was conducted by Tsanko Tsankov, a composer and professor at the National Academy of Music in Sofia. The program specified that the concert took place "under the auspices of the Yugoslav Prime Minister Milan Stojadinović." In the course of time, however, the political context of this event "has been forgotten," and it remained in the annals of Bulgarian musical history as the first joint participation of composers from the Contemporary Music Society abroad. ${ }^{51}$ The works of Petko Staynov (concert overture Balkan), Veselin Stoyanov (Capriccio), Ljubomir Pipkov (interludes from the opera Yaninite devet bratya [Yana's Nine Brothers]), Dimitar Nenov (Symphonic Sketches), Tsanko Tsankov (songs for soprano and orchestra)

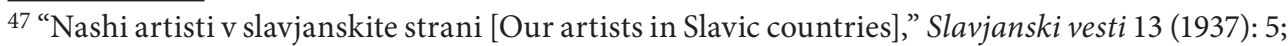
"Belgradski operni artisti na poseshtenije v nashata opera [Belgrade opera artists visit our opera]," Muzikalna misal 2 (1937): 12-13.

48 "Konzerti. Yugoslavjanski: Savmesten konzert s Balgaro-Yugoslavskoto druzestvo [Concerts. Yugoslav joint concert with the Bulgarian-Yugoslav society]," Slavjanska beseda 2 (1937): 89; Ivan Kamburov, "Konzert z yugoslavska muzika [Concert of Yugoslav Music]," Slavjanska beseda 2 (1937): 93-94.

49 "Iz zhivota na Slavjanska beseda [From the life of the Slavic talk]," Slavjanska beseda 2 (1937): 189-191.

50 "Iz slavjanskite strani. Belgrad. Sinfonichen konzert na Belgradskata filharmonija, posveten na Balgarskata muzika [From Slavic countries. Belgrade. Belgrade Philharmonics' symphonic concert dedicated to Bulgarian music]," Slavjanski vesti 14 (1937): 4-5.

${ }^{51}$ Ivan Hlebarov, Novata balgarska muzikalna kultura (izsledvane v dva toma). Tom parvi: 1878-1944 [The New Bulgarian Musical Culture (study in two volumes). Volume 1: 1878-1944] (Sofia: Haini, 2003), 299-300.
} 
and Pancho Vladigerov (concert overture Zemya [Earth]) included in the program were an original review of their creative achievements in the mid-1930s.

On the Bulgarian side, support for the Treaty of Eternal Friendship was also demonstrated with a Concert of Yugoslav Music by the State Philharmonics in the hall of the National Theater in Sofia on April 12, 1937, held under the auspices of the Minister of Public Enlightenment, Nikolay Nikolaev, and with Mirko Polić as guest conductor. The program featured works by Petar Konjović, Matija Bravničar, Mirko Polić, Miloje Milojević, Krešimir Baranović, Josip Slavenski and Milenko Živković, who were present at the concert, according to the press. Composer Veselin Stoyanov, a member of the Contemporary Music Society, delivered an address "about the musical collaboration between the two countries." 52 This way, regardless of the political patronage for the event, it became an occasion for new prospects of professional networking with the Yugoslav musicians. Such an emphasis on bilateral musical and cultural relations can also be found in the extensive review of the concert, where we can read: "for the art of music, there are no political boundaries. [...] Sooner or later, the compositions with artistic merits leap across wire fences and all kinds of artificial obstacles." ${ }^{53}$

The speed with which musical exchange surpassed the framework of political patronage was discussed by many people and collective art initiatives. During the period 1935-1939, for example, the cultural events of the Balgarsko rodno izkustvo (Bulgarian Native Art) society included more than 80 concert programs, with evenings dedicated to Hungarian, French, Czechoslovak, German, Italian, Polish, Romanian, Russian, Greek and Turkish music. ${ }^{54}$ It is easy to notice from this set of the national musical cultures that the organizers did not care much about the political situation or participation restrictions on musicians from countries that were members of one political alliance or another. The concerts included two Evenings of Yugoslav Music, featuring one of the most impressive ensembles of the Kingdom. At the first concert, the Belgrade Philharmonic Orchestra (conductor Lovro Matačić) performed works by Krešimir Baranović (overture to the opera Striženo-košeno [Sheared-Mowed]), Lucijan M. Škerjanc (Suite for string quartet), Božidar Kunc (Concerto for Piano and Orchestra in B Minor, op. 22, the soloist was not specified), Petar Konjović (prelude to the opera Koštana), Jakov Gotovac (Orači [The Ploughmen] and Symphonic kolo), Vojislav Vučković (Symphony) and Svetomir Nastasijević (Symphonic Suite). The

\footnotetext{
52 "Iz slavjanskite strani. Sofia. Sinfonichen konzert na Darzavnata filharmonija s yugoslavska muzika [From Slavic countries. Sofia. Symphonic concert of the State Philharmonics with Yugoslav music]," Slavjanski vesti 14 (1937): 5.

53 Vasil Spasov, "Yugoslavskijat simfonichen konzert [Yugoslav symphonic concert]," Chas 32 (April 19, 1937): 1.

54 Sofia Vasileva, "Kulturno druzestvo 'Balgarsko rodno izkustvo' 1929-1939 [The 'Bulgarian Native Art' culture society, 1929-1939]," Izdatel 1-2 (2006): 22-24.
} 
second one presented diverse genres and consisted of three parts: Part I featured Petar Kristićs Scherzo, Josip Štolcer-Slavenski's Nokturno and Petar Stojanović's symphonic poem Sava; in Part II the Zagreb String Quartet performed works by Ivan Mane Jarnović, Krsto Odak and Petar Konjović; and Part III were the Zagreb String Quartet and performances of singers. ${ }^{55}$

At the same time, messages appeared in the press about forthcoming guest performances of the opera ensembles from Belgrade and Zagreb in Sofia upon the invitation of the Native Art Society, which, however, were not confirmed by further information. Probably, they announced already the initiatives included in the cultural program, which in some cases remained unrealized or were carried out later and with the support of other musical institutions. One such event was the visit of the ballet ensemble of the Belgrade National Theater in June 1938. There was information about its preparation in the correspondence between the managers of the national theaters in Sofia and Belgrade. ${ }^{56}$ The ensemble performed a rich program, which included the ballets Đavo u selu (The Devil in the Village) by Fran Lhotka and The Firebird by Igor Stravinsky, as well as parts from Pyotr I. Tchaikovsky's Symphony No. 5. The artistic mastery of the Yugoslav dancers and "the strongly expressive choreography, rich in rhythm and forms," were highly appreciated by Bulgarian critics. ${ }^{57}$

But one of the peak of the Bulgarian-Yugoslav musical collaboration in the 1930s was still to come. In December 1939, Vladimir Tenev, the manager of the National Theater in Sofia, and the representative of the Zagreb-based UJDA association in Bulgaria signed a contract to stage Jakov Gotovac's opera Ero s onoga svijeta (Ero the Joker) in Sofia. ${ }^{58}$ The production was made entirely by Bulgarian artistic staff, consisting of young performers like conductor Asen Naidenov, director Dragan Kardzhiev, singers Georgi Belev, Pavel Elmazov, Mihail Lyutskanov, Nina Karova and others, who had already proved their creative abilities. ${ }^{99}$ It is a curious fact that Bulgarian tenor Stoyan Kolarov appeared as a guest performer in one of the central roles, Mića. At that time, he was a permanent member of the Zagreb opera, and was widely recognized by critics as one of its best interpretive singers. ${ }^{60}$ Moreover, the choreographer was Nina Kirsanova, the head of the ballet ensemble

55 "Iz glazbenog svijeta. Veliki uspjeh hrvatskih kompozitora i muzičara na festival u Bugarskoj [From the world of music. Great success of Croatian composers and musicians at a festival in Bulgaria]," Ćirilometodski vjesnik 10 (1937): 98-99.

56 Aleksieva et al. (Eds.), Balgaro-balkanski kulturni vzaimootnoshenia, 183-184.

${ }^{57}$ Maria Danailova, "Belgradskijat balet v Balgaria [The Belgrade ballet in Bulgaria]," Zlatorog XIX (1938): 275-278.

58 Aleksieva et al. (Eds.), Balgaro-balkanski kulturni vzaimootnoshenia, 188-189.

59 Zlata Bozhkova, Sofijska narodna opera. Memoari [Sofia National Opera. Memoirs] (Sofia: Nauka i izkustvo, 1975), 163.

60 Petar Mavrov, Tenorat Stojan Kolarov [The Tenor Stoyan Kolarov] (Varna: Morski svjat, 2019), 23-35. 
of the Belgrade National Theater. ${ }^{61}$ The premiere, which took place on February 28, 1940 , was attended by the composer, Jakov Gotovac. An extensive interview was made on the occasion of his visit to Bulgaria, in which he expressed his satisfaction with the performance and the opportunity to establish personal contacts with Bulgarian musicians and composers. ${ }^{62}$

The initial arrangements for the production were made in the conditions where a military conflict had already erupted, beginning with the "strange war" of Germany and the USSR against Poland (September 1-17, 1939). The old continent became the stage of another "theatrical" spectacle, which soon outgrew its territory and turned into a new World War. It did not miss the Balkans. The attack of Hitler's Germany on Yugoslavia and Greece (April 6, 1940) and the strong pressure on Bulgaria and Yugoslavia to join the Tripartite Pact revived the tension in their interstate relations. No less complicated were the internal political problems of both countries. In Yugoslavia, they spiraled into a political crisis so big that "the previously signed alliances began to be doubted, along with the previously pursued foreign policy and sometimes the integrity and the borders of the country." ${ }^{63}$ In Bulgaria, Georgi Kyoseivanov's government was replaced by the cabinet of Bogdan Filov (April 15, 1940), formed with a team of Germanophiles. The adopted policy of rapprochement with Yugoslavia was abandoned, and a clear disrespect for the Treaty of Eternal Friendship was shown. Differences emerged in the Union of Bulgarian-Yugoslav Societies regarding its character and courses of action. Growing increasingly complicated, the political situation impacted the intensity of the cultural connections, even leading them to break, according to some researchers. ${ }^{64}$

But was this really the case? When it comes to Bulgarian-Yugoslav musical connections during those years, we can find exceptions that show how conditional the attempts are to typologize the relations of music and politics in different stages or periods. An example of this can be seen in the life and creative work of Bulgarian composer Pancho Vladigerov (1899-1978), who left Germany in 1932 and returned

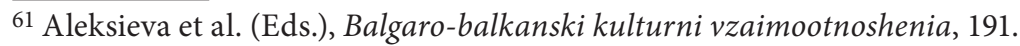

62 This interview, along with Gotovac's correspondence with Bulgarian musicians, was published in the study Rozalina Spasova, Stefanka Georgieva, "Unknown Letters of Jakov Gotovac, Boris Papandopulo, Josip Štolcer Slavenski in Boris Gaidarov's Archives (From the History of BulgarianCroatian Music Contacts between the 1920s and the 1940s)," Arti Musices 42/1 (2011): 25-30. A review by P. Rudevitz (alias of Vladimir Vassilev), published in the Zlatorog magazine in 1940 defines Gotovac's opera as "an example of folk art on national motives." Quoted in Borjana Mangova, "Deynostta na Sofiyskata narodna opera kato obekt na otrazhenie v spisanie Zlatorog (1920-1943) [The activity of the Sofia People's Opera as a subject of reflection in the Zlatorog magazine (19201943)]," in VII Akademichni proletni chetenia 'Balgarskata muzikalna kultura prez 20-te i 30-te godini na 20 vek,' edited by Anda Palieva (Sofia: Nazionalna muzikalna akademia, 2017), 268-281.

${ }^{63}$ Manchev, Istoria na balkanskite narodi, 306.

${ }^{64}$ Micheva, "Balgaro-yugoslavsko kulturno sblizhenie," 29.
} 
to Bulgaria for good. ${ }^{65} \mathrm{He}$ did not stop performing as a guest in the big musical centers, but the performances were clearly concentrated in central Europe and the Balkan countries (Warsaw, Budapest, Bucharest), and particularly in the neighboring Yugoslavia. Vladigerov gave multiple chamber music concerts and concerts of his own music in Belgrade (January 1935, February 1937) and Zagreb (1937, 1938, 1939), and in Ljubljana his opera Tsar Kaloyan was staged (May 1937). At the concerts, the audience did not spare its "spontaneous and sincere applauses, giving him recognition not only as a renowned world artist, but also as one of the greatest and most talented representatives of South Slavic music." 66

During those years, Vladigerov created a series of major instrumental and orchestral works, including his Symphony No. 1 (op. 33, 1939). Its first performance had a fate worth noting. ${ }^{67}$ After the Sofia Tsar's Military Symphony Orchestra formally refused to perform it without providing a reason, it was played for the first time by the Radio Belgrade Symphony Orchestra under the baton of Mihailo Vukdragović (1940). The latter wrote a review of Vladigerov's piece, emphasizing his contribution to contemporary Bulgarian musical culture. ${ }^{68}$ This concert turned into a sensation in the Sofia press, which the newspaper Dnevnik ran on the front page under the headline "Big production of Pancho Vladigerov rejected in Bulgaria reaps brilliant success in Belgrade." ${ }^{69}$ The article included fragments of an interview with the composer, in which he praised "the great musical culture of the splendid orchestra of Radio Belgrade," but also expressed his sincere regrets that his latest work was not performed for the first time in his native country. ${ }^{70}$ As a matter of fact, the program of this concert in Belgrade included another Bulgarian first performance-Symphony No. 1 (in F Major) by Boyan Ikonomov (1900-1973), a composer from the same generation as Vladigerov, whose work was written in Paris in 1937. It is strange that it remained outside the scope of attention of Bulgarian and Yugoslav musical critique. ${ }^{71}$

65 The motives for this were discussed by his biographer, and were mainly personal, not related to the complicated political situation in Germany. See Evgeni Pavlov-Klosterman, Pancho Vladigerov (Sofia: Muzika, 2000), 153.

${ }^{66}$ Novosti (January 25, 1935). Quoted in Pavlov-Klosterman, Pancho Vladigerov 133.

67 Pavlov-Klosterman, Pancho Vladigerov, 145.

68 Vreme (April 4, 1940). Quoted in Pavlov-Klosterman, Pancho Vladigerov, 145.

${ }^{69}$ P.Petko Tiholov, "Edna goljama produkzija na Pancho Vladigerov, othvarlena ot Balgaria, pozana bljaskav uspeh v Belgrad [Big production of Pancho Vladigerov rejected in Bulgaria reaps brilliant success in Belgrade]," Dnevnik (April 28, 1940): 1.

70 After Belgrade, Vladigerov's Symphony No. 1 was performed in Bucharest (April 12, 1940), and its first performance in Sofia was not until 1945. See Pavlov-Klosterman, Pancho Vladigerov, 144.

${ }^{71}$ Boyan Ikonomov studied composition and conducting under Vincent d'Indy at the Schola Cantorum in Paris. In 1934, he specialized in conducting with Felix Weingartner in Switzerland. From the 1930s to the 1960s, he worked at the musical department of the Sofia radio. His early works 
Vladigerov's creative activity continued in the beginning of the new decade. In 1940, he visited Zagreb, wrote his String Quartet No. 1 and dedicated it "to Prof. Milan Graf and his Zagreb Quartet." After that, his works were performed at the Bulgarian Music Week in Ljubljana (1940). These performances of Vladigerov's music in the Yugoslav musical centers require more detailed research and exploration of new historiographical materials. Because they are among the strongest proofs of the continuity of the musical contacts and their independence from the political situation and circumstances.

The 1930s mark the golden pages in the history of Bulgarian-Yugoslav musical relations, which remained unparalleled for the rest of the $20^{\text {th }}$ century. Belonging into the complex mix of geopolitical and Balkan dependencies, as well as in the focus of the complicated neighborly relations after WWI, they reflect certain specific connections between politics and music, mapping the "internal" stages in their development. The first period, from 1926(28) to 1931, is when culture was ahead of the thawing of political dialogue with initiatives for creative rapprochement (the First Belgrade Choral Society and the Bulgarian Choral Union). During the second one (1931-1937), which followed the process of political rapprochement, the cultural contacts are institutionalized with the activity of the Bulgarian-Yugoslav leagues in Belgrade and Sofia and other organizations, through joint initiatives in the fields of science, literature and arts. The third stage (1937-1940) marks the culmination in the musical and cultural exchange between the two countries, which builds up through the professional contacts of a new generation of Bulgarian and Yugoslav composers, with the participation of musical institutions, orchestras, operas and other actors. But the events on the political scene are just markers which delineate the chronology of the cultural rapprochement process up to the signing of the Treaty of Inviolable Peace and Eternal Friendship. In this sense, they assist the charting of different fields of the musical exchange, in which cooperation surpasses the ideological framework of the political situation and achieves relative independence. The leading role in reaching this level was played by prominent Bulgarian and Yugoslav intellectuals, whose empathy and participation in the intercultural dialogue remain a topic for future research. ${ }^{72}$

consist predominantly of chamber music and instrumental genres. His first symphonic work, as well as a large part of his works remain unfamiliar to this day and have not been published in Bulgaria.

72 This chapter was translated from Bulgarian to English by Mariana Pavlova. 


\section{Primary sources:}

Chas [Чac], Sofia, 1935-1940

Ćirilometodski vjesnik, Zagreb, (1933-1940)

Dnevnik [Дневник], Sofia, 1902-1944

Literaturen glas [Литературен глас], Sofia, 1928-1944

Muzikalen pregled [Музикален преглед], Stara Zagora, 1924-1929

Muzikalen zhivot [Музикален живот], Sofia, 1928-1931
Muzikalna missal [Музикална мисъл], София, 1936-1939

Slavjanska beseda [Славянска беседа], Sofia, 1937-1943

Slavyanski glas [Славянски глас], Sofia, 1902-1940

Slavjanski vesti [Славянски вести], Sofia, 1937-1943

Sv. Cecilija, Zagreb, 1887-

Zlatorog [Златорог], Sofia, 1920-1943

\section{Internet sources:}

Gardev, Borislav. Dimo Kazasov - talantliviyat demagog, accessed on February 4, 2019, https://liternet.bg/publish4/bgyrdev/podir/01_12.htm.

"Kratka istoria na Makedonskia nauchen institute." accessed on January 25, 2019, http:// www.mni.bg/2013/06/kratka-istoria-na-makedonskia-nauchen.html.

\section{References:}

Balareva, Agapia. [Баларева, Агапия] Horovoto delo v Bulgaria ot sredata na 19 vek do 1944 godina. Sofia: Balgarska akademia na naukite,1992. [Orig. in Bulgarian Cyrillic]

Balgaro-balkanski kulturni vzaimootnoshenia, 1878-1944, edited by Afrodita Aleksieva, Lilia Kirova, Nikolay Savov, Ginka Stamenova, Antoaneta Todorova. Sofia: Balgarska akademia na naukite, 1986. [Orig. in Bulgarian Cyrillic]

Bozhkova, Zlata. [Божкова, Злата] Sofijska narodna opera. Memoari. Sofia: Nauka i izkustvo, 1975. [Orig. in Bulgarian Cyrillic]

Dimitrov, Ilcho. [Димитров, Илчо] Minaloto, koeto beshe blizko, a stava vse po-dalechno. Sreshti i razgovori. Sofia: Universitetsko izdatelstvo "Sv. Kliment Ohridski," 1992. [Orig. in Bulgarian Cyrillic]
Georgieva, Stefanka. "The Idea of South Slavic Unity among Bulgarian Musicians and Intellectuals in the Interwar Period." In Kosta P. Manojlović (1890-1949) and the Idea of Slavic and Balkan Cultural Unification, edited by Vesna Peno, Ivana Vesić, Aleksandar Vasić, 37-56. Belgrade: Institute of Musicology SASA, 2017.

Hlebarov, Ivan. [Хлебаров, Иван] Novata balgarska muzikalna kultura (izsledvane $v$ dva toma). Tom parvi: 1878-1944. Sofia: Haini, 2003. [Orig. in Bulgarian Cyrillic]

Hristov, Dobri. [Христов, Добри] Muzikalno-teoretichesko i publitsistichesko nasledstvo. Vol. 2, edited by Venelin Krastev. Sofia: Balgarska akademia na naukite, 1970. [Orig. in Bulgarian Cyrillic] 
Hristov, Dobri, "Ritmichnite osnovi na narodnata ni muzika." Sbornik s narodni umotvorenia 27 (1913): 1-48. [Orig. in Bulgarian Cyrillic]

Hristov, Dobri, “Tehnicheskijat strojez na balgarskata narodna muzika (pitmika, metrika, tonalni i harmonichni osobenosti)." In Dobri Hristov. Muzikalno-teoretichesko i publizistichno nasledstvo. Vol. 2, edited by Venelin Krastev, 63-127. Sofia: Balgarska academia na naukite, 1970. [Orig. in Bulgarian Cyrillic]

Hristov, Dobri. "Makedonskite balgarski pesni." In Dobri Hristov. Muzikalno-teoretichesko i publizistichno nasledstvo. Vol. 2, edited by Venelin Krastev, 131-154. Sofia: Balgarska academia na naukite, 1970. [Orig. in Bulgarian Cyrillic]

Kaufman, Nikolay. [Кауфман, Николай] "Dobri Hristov - praktikat." In Dobri Hristov i balgarskiyat 20 vek, edited by Elena Toncheva, 62-67. Sofia: Institut za izkustvoznanie, 2005. [Orig. in Bulgarian Cyrillic]

Kazasov, Dimo. [Казасов, Димо] Dneshna Yugoslavia. Sofia, 1938. [Orig. in Bulgarian Cyrillic]

Kazasov, Dimo. Izbrani proizvedenia. [With a foreword by the author] Editor and compiler Stefan Zhelev. Sofia: Otechestven front, 1987. [Orig. in Bulgarian Cyrillic]

Kuba, Ludvík. Slovanstvo ve svỳch zpevĕch. Sborníkpísni všech slovanskỳch nàrodì spưvodními texty a českỳmi překlady. (Kniha XIV. Díl V. Písne juhoslovanské. Čast VIII. Písne Makedonské). Prague: self-published, 1928.

Litova-Nikolova, Lidia. [Литова-Николова, Лидия] “Dobri Hristov i sbornikat mu '66 narodni pesni na makedonskite balgari”' In Dobri Hristov $i$ balgarskiyat 20 vek, edited by Elena Toncheva, 72-77. Sofia: Institut za izkustvoznanie, 2005. [Orig. in Bulgarian Cyrillic]
Manchev, Krastyo, Bistritski, Valerian. [Манчев, Крьстьо, Бистрицки, Валериан] Bulgaria $i$ neynite sasedi (1931-1939). Politicheski i diplomaticheski otnoshenia. Sofia: Nauka i izkustvo, 1978. [Orig. in Bulgarian Cyrillic]

Manchev, Krastyo. Istoria na balkanskite narodi. Tom 3, (1918-1945). Sofia: Paradigma, 2008. [Orig. in Bulgarian Cyrillic]

Manchev, Krastyo. Yugoslavia i mezhdunarodnite otnoshenia na Balkanite 1933-1939. Sofia: Balgarska academia na naukite, 1989. [Orig. in Bulgarian Cyrillic]

Mangova, Borjana. [Мангова, Боряна] "Deynostta na Sofiyskata narodnata opera kato obekt na otrazhenie v spisanie Zlatorog (1920-1943)." In VII Akademichni proletni chetenia 'Balgarskata muzikalna kultura prez 20-te i 30-te godini na 20 vek, edited by Anda Palieva, 268-281. Sofia: Nazionalna muzikalna akademia, 2017. [Orig. in Bulgarian Cyrillic]

Mavrov, Petar. [Мавров, Петър] Tenorat Stojan Kolarov (1907-1964). Varna: Morski svjat, 2019. [Orig. in Bulgarian Cyrillic]

Micheva, Zdravka. [Мичева, Здравка] "Balgaro-yugoslavsko kulturno sblizhenie 1933-1940." Istoricheski pregled 3 (1967): 3-29. [Orig. in Bulgarian Cyrillic]

Milanović, Biljana. “The Contribution of Kosta P. Manojlović to the Foundation and Functioning of the Južnoslovenski pevački savez [South-Slav Choral Union]." In Kosta P. Manojlović (1890-1949) and the Idea of Slavic and Balkan Cultural Unification, edited by Vesna Peno, Ivana Vesić, Aleksandar Vasić, 65-90. Belgrade: Institute of Musicology SASA, 2017.

Otchet na Balgaro-yugoslavskoto druzhestvo za godinata 1933-1934. [Without publishing details]. [Orig. in Bulgarian Cyrillic] 
Otchet na Balgaro-yugoslavskoto druzhestvo za godinata 1934-1935. [Without publishing details]. [Orig. in Bulgarian Cyrillic] Pavlov-Klosterman, Evgeni. [Павлов-Клостерман, Евгени] Pancho Vladigerov. Sofia: Muzika, 2000. [Orig. in Bulgarian Cyrillic]

Spasova, Rozalina, Georgieva, Stefanka. "Unknown letters of Jakov Gotovac, Boris Papandopulo, Josip Štolzer Slavenski in Boris Gaidarov's Archives (From the History of Bulgarian-Croatian Music Contacts between the 1920s and the 1940s)." Arti Musices 1 (2011): 5-35.

Tiholov, Petko. [Тихолов, Петко] Kam varhovete na izkustvoto. Sofia: Muzika, 1979. [Orig. in Bulgarian Cyrillic]
Vesić, Ivana, Peno, Vesna. "Kosta P. Manojlović: A Portrait of the Artist and Intellectual in Turbulent Times." In Kosta P. Manojlović (1890-1949) and the Idea of Slavic and Balkan Cultural Unification, edited by Vesna Peno, Ivana Vesić, Aleksandar Vasić, 13-25. Belgrade: Institute of Musicology SASA, 2017.

Yapova, Kristina. [Япова, Кристина] Arhivat na Dobri Hristov. Katalog. Sofia: Matom, 2002. [Orig. in Bulgarian Cyrillic] Zaharieva, Svetlana. [Захариева, Светлана] "Muzikalno-folklorno izsledvane i nazionalisam. Pogled kam minaloto s missal za nastojashteto." Bulgarian musicology 1 (1995): 19-38. [Orig. in Bulgarian Cyrillic] 

9.

\title{
Music during the Cold War: A Romanian story
}

\author{
Florinela Popa
}

After WWII, Romania found itself in the sphere of influence of the Soviet Union and became a member of the Warsaw Pact in 1955. As such, the country was involved in the Cold War from 1948 to 1989. In this context, its foreign policy went through several stages, which can also be observed at the level of music both in the diplomatic relations it cultivated and in the research produced in Romania. The first phase was characterized by the total subordination to Moscow, the striving toward establishing a "union of brotherly nations" with other "people's democracies". In the second phase, Romania distanced itself from the USSR, and the third phase was one of international isolation.

\section{Phase 1}

The conditions under which Romania finished WWII-unexpectedly switching sides to the Allies at the last minute and being "liberated" by the Red Army-rendered inevitable its positioning within the Soviet Bloc. After becoming a people's republic led by a single party (the Romanian Workers' Party) on December 10, 1947, Romania signed on 4 February, 1948 a Treaty of Friendship, Collaboration and Mutual Assistance with the Soviet Union, ${ }^{1}$ thus firmly distancing itself from the West and relinquishing any assistance the Marshall Plan might have offered.

The faithful copying of the Soviet model and the virulent pro-Soviet propaganda pushed Romania toward totalitarianism at full speed. As all other sectors of Romanian cultural life, music also entered the grinder of Sovietization: musical institutions were reorganized and subjected to political control, formalist tendencies in music were "exposed," and musicians' diplomatic relations had to conform to the country's foreign policy.

The Muzica journal, turned into the regime's mouthpiece in 1950, testifies to the intense exchanges with the Soviet Union in particular, but also with Bulgaria, the German Democratic Republic, Hungary, Czechoslovakia, the Ukrainian Soviet Socialist Republic and the Moldavian Soviet Socialist Republic. Following the

1 Dennis Deletant, "România sub regimul comunist (decembrie 1947-decembrie 1989) [Romania under Communist Rule (December 1947-December 1989)]," in Istoria României, edited by M. Bărbulescu et al. (Bucharest: Corint, 2012), 408. 
Tito-Stalin Split of 1948, not even a passing reference to Yugoslavia appeared in Muzica throughout the 1950s. During the heyday of Stalinism, international festivals were organized - such as the Romanian Music Week (1951), the Bulgarian Music Week (1952), or the Prague Spring International Music Festival (ongoing since 1946) - designed to connect musicians from "friendly countries."

Through the manner in which the press records such events, the power relations between the participants are plain to see: the musicians from the USSR enjoy a position of clear superiority, having the first and last word, praising and criticizing with equal impunity. Then there is the "brotherly" position, the position of "friendship" among apprentices from people's democracies, needing to be guided in the assimilation of Leninist-Stalinist teachings. The presence of any Western name-which is very rare anyway-is invariably accompanied by the designation "progressive" and presented as a sort of dissidence against capitalism. The implicit opposition of "friendly countries" versus "capitalist countries" leaves no room for even the tiniest doubt as to the official political line: "Composers from all over the country $[\ldots]$, representatives of friendly countries, and progressive artists from capitalist countries participated in the Romanian Music Week." 2

It is evident that the relations between Romanian and USSR musicians were marked by clear subservience, despite the professed "friendship" and "brotherhood." It is significant that the only musicians invited to lecture at the Romanian Composers' Union during the Romanian Music Week were members of the USSR delegation: Vladimir G. Zakharov, Vasily P. Solovyov-Sedoi and Alexander G. Arutiunian. Muzica published their heavily politically oriented talks in full, but no other foreign participants' impressions or perspectives.

Zakharov, for instance, criticized the poor representation of the "fight for peace" and "friendship between peoples" in the Romanian music of the time-two hot topics, suited to the position feigned by the USSR during the Cold War: "We didn't have the opportunity to listen to any great symphonic works dedicated to the fight for peace. We listened to too few works dedicated to the friendship between peoples, even if the motto of the week is Let us sing the peace and friendship between peoples."

The implications of the Cold War in music are also discernible in the picturesque speech given by Solovyov-Sedoi. Under the guise of a plea for the valorizing of folklore, he condemns Western music, recounting a most likely fictitious event which supposedly took place at the 1948 Second International Congress of Composers and Music Critics in Prague:

\footnotetext{
2 “Săptămâna Muzicii Românești [Romanian Music Week]," Muzica 5 (1952): 20.

3 Vladimir Grigoryevich Zakharov, "Cuvântarea compozitorului V.G. Zaharov ținută în ședința din 28.IX.1951 a Plenarei Uniunii Compozitorilor din R.P.R. [Composer V. G. Zakharov's Speech at the Meeting of September 28, 1915 of the Plenary of the Romanian People's Republic Composers' Union]," Muzica 5 (1952): 59-60.
} 
A Dutch musician uttered the following absurd phrase: "How are Dutch composers supposed to write music if there is no folk music in the Netherlands?"

I remember that the audience received these words with a somber silence. Indeed, it is difficult to imagine a nation without its own music. I believe that things are rather different. It's that Dutch musicologists study imported music and the music of their local composers, written in the likeness of that imported music or of the music they receive from capitalist countries in exchange for Dutch cheese, the principle being: a wheel of cheese for a little jazz song, whose sensationalist title reads Mary Likes the Smell of Cheese in Spring. But we, the composers from people's democracies and the composers from the Soviet Union, know very well that not peoples, but only politicians [from capitalist countries, $A / N$ ] prevent through all available means the peoples' national self-determination. ${ }^{4}$

The conclusion of this grotesque peroration is that "Romanian musicologists and composers do not need to import themes for their works." ${ }^{5}$

In the early 1950s, all Romanian musicians visiting the USSR wrote enthusiastically about the level reached by the Soviet musical establishment, and by Moscow in particular. More often than not, the discourse nevertheless degenerates into singing praise to Stalin, who comes to be seen not only as the leader of the Eastern Bloc, but as an embodiment of the ideal politician, for whom the whole world longs, including those under "subjugation" in the West:

Visiting the Museum with gifts to comrade Stalin and the Museum of the Revolution, I was able to realize once again that comrade Stalin is indeed the world's most beloved man. Hundreds of thousands of gifts from all countries of the world, among which are Austria, Spain, the Netherlands, Indonesia, Tunisia, Thailand, Iran, Lebanon, France, Brazil, Argentina, testify to the fervent love that simple people all over the world feel for the great leader of the Soviet people. 6

Between 1950 and 1953 in particular, artistic exchanges between Romanian musicians and those from other "friendly countries" intensified. In presenting such

4 Vasily Pavlovich Solovyov-Sedoi, "Cuvântarea compozitorului V.P. Soloviev-Sedoi ținută în ședința din 29.IX.1951 a Plenarei Uniunii Compozitorilor din R.P.R. [Composer V. P. SolovyovSedoi's speech at the meeting of September 28, 1915 of the Plenary of the Romanian People's Republic Composers' Union]," Muzica 5 (1952): 63-64.

5 Ibid.

6 Mauriciu Vescan, “Aspecte din viața muzicală a capitalei Uniunii Sovietice [Aspects of musical life in the capital of the Soviet Union]," Muzica 12 (1952): 146. 
events, the press highlighted their "political and cultural" 7 or "political and artistic" 8 significance. References to the Cold War even tainted speeches on children's artistic performances. The visit of the Kreuzchor children's ensemble from Dresden to Romania in 1952 was seen "as a materialization of the collective and brotherly efforts of the working people in the Romanian People's Republic and in the German Democratic Republic to join forces, collaborate and fight for the protection of peace and culture, threatened by American and English imperialists." 9

Beyond such slogans as "the fight for peace," most texts that emphatically support the "peace and friendship between peoples" allude to the "enemy" - the Western, capitalist, "imperialist" world. As a concession, only the (few) Western "progressive" musicians who are in contact with the Socialist Bloc and who might aspire to a life similar to the one in the Soviet Union are mentioned.

On the front page of the 12/1952 issue, Muzica published Stalin's answers to a New York Times correspondent on the Cold War. To the question as to where the international tensions originated, Stalin answered: "Everywhere and anywhere the aggressive actions of the 'cold war' policy against the Soviet Union show themselves." 10 The no less aggressive policy of the Soviet Union and its satellite states can be deduced even from ordinary texts on music, whose leitmotif is the "peace and friendship between peoples."

A common denominator of the attitude toward the West is the demonization of Anglo-American imperialism, the ever-present enemy, guilty, for example, of the deepening cultural rupture between East and West Germany, as is apparent from several texts on music published in the GDR. Here is an example:

The new Germany weaves its song with the fight for freedom from the tyranny of Anglo-American imperialism. Just as highways, like asphalt rivers, regularly display large posters featuring cartoons-hilarious ones at that-addressing the Yankees who will not leave with the famous "Go home," the people have their cherished melody, quivering on the lips of all free Germans, the well-known Go home, with an ironic syncopated rhythm chorus: "Go home, Yank! Yank, go home! Say goodbye to father Rhine."11

\footnotetext{
7 See Vasile Cristian, "Soli ai muzicii din țările prietene [Heralds of Music from Friendly Countries]," Muzica 9 (1952): 84.

8 See Hilda Jerea, "Festivalul muzicii bulgare [Bulgarian Music Festival]," Muzica 9 (1952): 97.

9 Cristian, "Soli ai muzicii din țările prietene," 85.

${ }^{10}$ Joseph Vissarionovich Stalin, "Răspunsurile tovarășului I. V. Stalin la întrebările primite din partea corespondentului diplomatic al lui New York Times, James Reston, la 21 decembrie 1952 [Comrade's J. V. Stalin's Answers to the Questions of the New York Times Diplomatic Correspondent James Reston from December 21, 1952]," Muzica 12 (1952): 9.

11 Virgil Gheorghiu, "Impresii din Republica Democrată Germană [Impressions from the German Democratic Republic]," Muzica 12 (1952): 148.
} 
The author of the article recounts the success Romanian baritone Octav Enigărescu apparently enjoyed with this song at sold-out performances in Dresden, Berlin and Erfurt: "You could tell that the German wishes with all his heart that the uninvited guests would leave, that he is anxious to preserve peace, and that he will know how to defend it at all times and at all costs." ${ }^{12}$ Such comments are hard to believe, especially since East Germany had been a Moscow's satellite state and under strict control of the Soviets for three years. Therefore, the "uninvited guests" could not have been the Americans.

The dissatisfaction with "Anglo-American imperialists" allegedly expressed by a West German conductor in the very city of Berlin cast, yet again, a somber shadow over West Germany. The name of the conductor is omitted although his words are given as a quotation. With this in mind, we may assume that both the conductor and his remark were invented:

I remember how a West German conductor, wanting to meet the delegation of Romanian artists, approached us in Berlin and said: "I am an apolitical man, but I want to perform the music of my country. The Anglo-American imperialists will not allow it. Beethoven's Fidelio, Mozart's Le nozze di Figaro are very rarely performed. Instead, decadent ballets and jazz music abound." 13

The 1952 Prague Spring International Music Festival also provided fruitful material for anti-Capitalist tirades. Considerable international participation of musicians from both the East and the West occasioned composer Alfred Mendelsohn to play the two worlds off against each other in his article "Impressions from Prague." In it, he makes a clear distinction between the "Socialist state, supporter of the arts and artists, and the capitalist state, the enemy of true art and progressive artists." 14 Notwithstanding these claims, the composer proceeds to deny the existence of the Iron Curtain, claiming it is an invention of the "scheming Anglo-Americans":

Musicologists and performers from Capitalist countries will be able to bring to the working class and the progressive strata from their countries the message of love and trust of the builders of Socialism, the testimony of a brotherly welcome and of the high level in composition and performance, from here where the proletariat is in power. They will help in dispelling the stupid lie put forth by the scheming Anglo-Americans about the alleged "iron curtain." Between the people deeply convinced of the importance of the fight for peace and of the fight against all oppression and crime committed against peaceful nations, there is no iron curtain. ${ }^{15}$

\footnotetext{
12 Ibid.

13 Ibid., 149.

14 Alfred Mendelsohn, “Impresii din Praga [Impressions from Prague],” Muzica 9 (1952): 104.

15 Ibid., 106.
} 
Soviet propaganda went even further, exploiting the "enemy's" every weakness, real or invented. The insinuation, for instance, that English musicians would begin craving a cultural life similar to that in the East-in a Muzica article titled "English Musicians' Fight for Peace" - is hilarious, at the very least:

The economic crisis in England caused by governmental policy on armament burdens the English musicians' lives as well. Concerts are ever rarer, many philharmonic halls close their gates, as the funds allotted by the state to cultural necessities are heavily reduced [...]. English musicians begin to understand that the development of musical art is only possible in an era of true peace, of durable peace won through the joint fight of all peoples. ${ }^{16}$

Another news article, one on American composers being censored at home, without being a fiction of Soviet propaganda, reflects the vulnerability experienced in the West for about a decade by the threat posed by the Soviet Union. Unfortunately, the Communist witch-hunt in the US beginning in the late 1940s due to tensions engendered by the Cold War was quite close to the terror instituted in the Eastern Bloc for a while:

The works of seven renowned American composers were termed "subversive" and banned on the order of McCarthy, ${ }^{17}$ the author of the wellknown violent measures. The seven composers are: George Gershwin, Aaron Copland, Leonard Bernstein, Roy Harris, Randall Thompson, Virgil Thomson and Roger Sessions. Aaron Copland [...] attracted McCarthy's ire by dedicating one of his works to Abraham Lincoln, ${ }^{18}$ and Roy Harris by writing a symphony called the "Stalingrad Symphony"19 inspired by the Soviet Army's historical victory at Stalingrad. 20

This extremely dark phase of the Cold War, in which Romania was also trapped, left a visible mark on the establishment of diplomatic relations through music. Romanian output of the time could not evade Sovietization. Also relevant is

\footnotetext{
16 “Din alte țări [From Other Countries]," Muzica 2 (1953): 76-77.

17 Joseph Raymond McCarthy (1908-1957), American politician, Republican Senator for Wisconsin between 1947 and 1957. In a time when Cold-War tensions fed the fears of Americans who worried about a possible substantial Communist subversion, McCarthy was extremely active in preventing the spread of Communism to the US. He is known for his accusations (many of them false) with regard to several Soviet and Communist spies infiltrating the US government, universities, the film industry, etc. ${ }^{18}$ Lincoln Portrait (1942) for narrator and orchestra.

19 The information is inaccurate. The author is in fact talking about Symphony No. 5 (1942), untitled but dedicated "to the heroic and freedom-loving people of our great ally, the Union of Soviet Socialist Republics." See https://www.naxos.com/catalogue/item.asp?item_code $=8.559609$, accessed August 26, 2020.

20 "Din alte țări," 77.
} 
the immense quantity of works dedicated to Stalin or to the "peace and friendship between peoples." 21

\section{Phase 2}

After Stalin's death, Romania took at first tentative, then increasingly steadfast steps toward autonomy from Moscow. As part of the Warsaw Pact, Romania was involved in the Hungarian Uprising of 1956, but not in the invasion of Czechoslovakia in 1968. The support provided to the USSR in the former event influenced-according to some historians-the withdrawal of Soviet troops from the country in 1958.22 The refusal to participate in the latter and its condemnation led to an interesting reconfiguration in Romania's foreign policy.

Signs of Romania's distancing from Moscow appear at the beginning of the 1960s. An important step was the rejection of the plan initiated by Khrushchev and presented in Moscow to members of Comecon (the Council for Mutual Economic Assistance) on August 3-5, 1961, which would have forced Romania "to remain a provider of raw materials and to abandon its rapid industrialization program." 23 Although a follower of Leninist-Stalinist ideology, Gheorghe Gheorghiu-Dej, the then Communist leader, became much more popular among Romanians with a series of anti-Russian measures introduced gradually from 1963: the Maxim Gorki Institute in Bucharest was closed down, Russian was no longer a compulsory subject in schools, Russian street names were replaced, ARLUS (the Romanian Association for Strengthening the Bonds with the Soviet Union) and later the Cartea Rusă (Russian Book) media outlet were dissolved.

After taking power in 1965, Nicolae Ceaușescu continued his predecessor's National-Communist stance, one based on rapid industrialization and an autonomous foreign policy. It was probably by no accident that "Romania was the first country of the Eastern Bloc to establish diplomatic relations with West Germany in 1967, and not break off diplomatic relations with Israel after the Six-Day War." 24 Such gestures and especially Ceaușescu's refusal to take part in the Warsaw Pact troops' invasion of Czechoslovakia made Romania appealing to the West, and it was not long before the latter exploited this apparent crack in the Socialist Bloc. 25

\footnotetext{
${ }^{21}$ Until 1950, "tens and tens of works" dedicated to Stalin had already been written, "filled with the warmth of this love." See Anatol Vieru, "Succesele muzicii noastre în urma însuşirii principiilor Hotărârii CC al PC (b./bolșevic) asupra operei Marea prietenie de V. Muradeli [The Success of Our Music Following the Implementation of the Principles of the Decree of the Central Committee of the Bolshevik Communist Party on the Opera The Great Friendship by V. Muradeli]," Muzica 1 (1950): 15.

22 See Deletant, "România sub regimul comunist," 431.

${ }^{23}$ Ibid., 435.

24 Ibid., 439.

${ }^{25}$ Ibid., 446.
} 
This was also the context of US President Nixon's visit to Romania in August 1969, as well as Ceaușescu's visits to the US in October 1970 and to France in June 1970.

By and large, the 1960s were Romania's only period of relatively relaxed domestic policy and liberalization, with ideological control reaching its lowest point between 1965 and 1970. Western television series being broadcast on Romanian television and a Pepsi Cola factory opening in Constanța in 1967 are seen as the "ultimate symbol of concessions made to Western 'capitalism."' 26

Romanian music-in terms of both composition and international networking-enjoyed this wave of freedom moderately. A reasonably faithful reflection of this phase, whose developments become apparent when compared with the period of Sovietization, can be found in the policy adopted by Muzica, the regime's main means of communication in the field of music until the beginning of the 1990s.

A timid change in tone emerged in the mid-1950s. The polarization between "friendly countries" and "capitalist countries", as well as the omnipresence of the term "progressive" in relation to Western musicians endorsed in the East faded.

In the new political context, at least on a discursive level, the regime wanted to promote Romanian music "on all meridians," ignoring as much as possible the schism between the Socialist and the Capitalist Blocs. It was for reasons such as this that the George Enescu International Festival was created in 1958. Organized every three years, it became a good indicator of Romanian political developments. Despite some inherent ups and downs, it remains Romania's most important musical event to this day. The first five editions (1958, 1961, 1964, 1967 and 1970), starring first-class performers and orchestras, were illustrative of Romania's relative international openness (the first edition boasted such guests as Yehudi Menuhin, David Oistrakh, Halina Czerny-Stefańska, Nadia Boulanger, Monique Haas, Yakov Zak, Claudio Arrau, John Barbirolli, Carlo Felice Cillario and Carlo Zecchi).

The idea of Romanian music attracting notice worldwide was also a subject of Muzica's editorial policy, as its pages reported with patriotic pride the success that Romanian music enjoyed overseas, without overt political bias:

The universal acclaim in the press, from Moscow and Leningrad to Vienna, Paris, Helsinki, Athens, Rome, Washington or Philadelphia, bears witness to the fact that today our music has become and will become with each passing day more widely-known and more valued. ${ }^{27}$

Despite this professed internationalization, Romanian musicians' relations with colleagues abroad were frequently obstructed. Romanian composers were not allowed to participate in prestigious international festivals such as the Warsaw Autumn until

\footnotetext{
${ }^{26}$ Ibid., 443-444.

27 George Georgescu, "Să promovăm mai departe arta și cultura noastră nouă socialistă [Let us continue to promote our new socialist art and culture]," Muzica 12 (1962): 15.
} 
1965, as the then president of the Composers' Union Ion Dumitrescu "was opposed to the idea that the 'experimental music' of the younger generation should be known abroad." 28 There were also no copyright conventions to facilitate the travel of Romanian music abroad. An example of this was a refusal to collaborate with important Western publishing companies (e.g. Schott) interested in Romanian music. ${ }^{29}$

Despite the fact that it was difficult to have an "exchange of opinions or concepts with brothers beyond the 'iron curtain"' Romanian music took quite a step back from socialist realism, and quite a step forward on its way toward finding its own voice. In addition to the "series of scores in which contemporary Romanian music writing is grounded, new original systems take shape, formulated in important studies. This leads to a coalescing of aesthetic alternatives which, in the following decades, would turn out to be just as 'modern' as those from other parts of the world." 30

It was not until 1968-1970 that ideological control clearly slackened, and this happened, symbolically, in relation with the impact of the 1968 moment (essentially the phase of intensified relations between several Romanian musicians and the West). Composer Anatol Vieru's presence in Washington and New York, and musicologist Octavian Lazăr Cosma's ${ }^{31}$ study trip to the US took place in the context of Romania's new high-level political relations with the US: President Nixon's visit to Bucharest (1969), followed by Ceausescu's visit to Washington (1970). (It is, perhaps, ironic that the two musicians, ultimately famous figures in Romanian composing and musical historiography, had studied in Moscow and Leningrad, respectively.) Zeno Vancea's presence in the Federal Republic of Germany in 1968 for a series of conferences was a consequence of the diplomatic relations Romania had established with West Germany a year earlier. Again, Ceaușescu's visit to France brought a wave of Romanian music to French radio. ${ }^{32}$ These events, as well as others reflected in Muzica, ${ }^{33}$ suggest a more coherent attempt at internationalization.

\footnotetext{
${ }^{28}$ Valentina Sandu-Dediu, Muzica românească între 1944-2000 [Romanian music between 1944-2000] (Bucharest: Editura Muzicală, 2002), 27.

${ }^{29}$ Ibid., 26-28.

${ }^{30}$ Ibid., 28.

31 Zeno Vancea, Anatol Vieru, "Muzica românească în context mondial - convorbire cu Zeno Vancea și Anatol Vieru [Romanian Music in an International Context - A Conversation with Zeno Vancea and Anatol Vieru]," Muzica 4 (1968): 20-23; Octavian Lazăr Cosma, "Itinerar muzical american [American musical itinerary]," Muzica 6 (1970): 37-42.

32 See Radu Gheciu, "Cu prilejul vizitei tovarășului Nicolae Ceaușescu, Președintele Consiliului de Stat al R.S. România în Franța: Muzică românească la posturile franceze de Radio [On the occasion of the visit to France of vomrade Nicolae Ceaușescu, president of the State Council of the Socialist Republic of Romania: Romanian music on French airwaves]," Muzica 8 (1970): 4.

${ }^{33}$ See Alfred Hoffman, "Vizită artistică în Grecia [Artistic visit to Greece]," Muzica 11 (1970): 28-32; Dumitru Bughici, "Note de călătorie (în Italia și RFG) [Travel notes (from Italy and the Federal Republic of Germany)]," Muzica 11 (1970): 32-33; Smaranda Oțeanu, "Secvențe muzicale
} 
With regard to the relative freedom that the Romanian music press of the time enjoyed, an international survey on "The pathways of contemporary music" 34 is iconic, registering relaxed ideological opinions of several Western composers. The question "How do you view the issue of national character in the arts?"-one of the clichés and obsessions of Romanian musicology—received such answers as: "To be nationalist per se is just as useless as to abstractly wish to be universal" (Thomas Marco, Madrid); "Music is an international art" (Rolf Liebermann, Hamburg); "Esperanto is nevertheless not a language [...]. Eskimos composing in the Neapolitan style are ridiculous" (Werner Egk, Munich). ${ }^{35}$

\section{Phase 3}

Paradoxically, Romania's assumed external autonomy was counterbalanced by a disastrous, nationalist-isolationist domestic policy. Through the so-called July Theses of 1971, Ceaușescu imposed a new version of socialist realism under the name of "socialist humanism." Such measures taken in cultural policy, as well as the severe austerity to which Ceaușescu subjected the population in order to pay for the country's foreign debt, led Romania to a state of unprecedented isolation, especially in the 1980s. The fact that, for instance, Gorbachev's perestroika and glasnost reforms were seen by the Romanian leader as concessions made to the "international enemy of the people (capitalism)" 36 is illustrative of the nature of Romania's schizoid position.

With the July Theses, Romanian culture, and Romanian music with it, entered a process of Neo-Stalinization, wherein the cult of Ceaussescu's personality became more and more pronounced. Measures were taken to align musical life to the new commandments: "politically engaged art" in the long term is called for, designed to support the building of Socialism and Communism in the country, while dalliances with the experimental, the avant-garde or the mathematical were criticized. ${ }^{37}$

Iugoslave [Yugoslav musical reports]," Muzica 11 (1970): 35-37; Theodora Albescu, "Vara muzicală de la Taormina [Musical summer in Taormina]," Muzica 11 (1970): 37-39.

${ }^{34}$ Iosif Sava, "Anchetă internațională: Drumurile muzicii contemporane [International survey: The pathways of contemporary music]," Muzica 4 (1968): 1-9.

${ }^{35}$ Ibid., 2, 4, 5.

${ }^{36}$ Deletant, "România sub regimul comunist," 468.

37 See Nicolae Călinoiu, "Referatul prezentat de tov. Nicolae Călinoiu, directorul Direcției Muzicii din Consiliul Culturii și Educației Socialiste, la consfătuirea din 12 august 1971, privind repertoriul instituțiilor muzicale de spectacole și concerte pe stagiunea 1971-72 [Report presented by Comrade Nicolae Călinoiu, head of the Music Section of the Council of Socialist Culture and Education, at the gathering of August 12,1971, with regards to the repertoire of the musical institutions for shows and concerts for the 1971-1972 season]," Muzica 9 (1971): 1-10. 
In the scholarly press, articles debating Romanian music in an ideological key exponentially multiplied.

The artistic output of Nicolae Ceaușescu's new friends began to be popularized-such as, for instance, a work about the Korean fight against Japanese invasion performed by the Pyongyang Opera Ensemble:

Through the revolutionary opera The Sea of Blood, a collective work based on the national Korean epic of the same title [...], our audiences learned about the emotional hues of a sensibility, engendered by a genuinely mystical love of country and freedom, belonging to a people which will find neither rest nor complete happiness until peace and justice shield human fate worldwide. ${ }^{38}$

The fact that such strange artistic productions served as a model for Ceaussescu appears all the more frightening in the context of the re-ideologization of Romanian music.

Significant for this isolationist phase is, for instance, the direction the George Enescu International Festival undertook, from the first editions' opulence to the evident decline beginning in 1973: the festival was shortened to one week, the instrumental competition was canceled, and international participation was reduced to the point that the festival almost became a local event. The 1985 edition was the bottom point in this regard, as it featured no less than 75 Romanian composers. Foreign participants were a minority, chosen among musicians untroubled by politics, who were probably very well remunerated and willing to unconditionally praise Romanian music or performers in the Romanian press. ${ }^{39}$ In the opening address, Nicolae Călinoiu, president of the Composers' Union, presented the Enescu Festival as a sort of spinoff of the national festival Cântarea României (Song of Romania). An expression of nationalist policy and the personality cult surrounding Ceaușescu, Cântarea României understated the importance of the professional musician, emphasizing instead music made by amateurs. Despite aggressive propaganda, Cântarea României's international visibility did not even match that of North Korean artistic productions:

The National Festival Cântarea României, a large-scale manifestation of work and creative production in which millions of talents in all fields participate, revealed more than once an exceptional musical potential which brought about a continuous rise of Romanian artistic life, contributing to the cultivation and the development of the Romanian people's cultural

\footnotetext{
38 George Sbârcea, "Turneul Ansamblului de operă din Phenian [The tour of the Pyongyang Opera Ensemble]," Muzica 4 (1972): 26-27.

39 "Din opiniile oaspeților străini la festival [A sample of the opinions of foreign guests at the festival]," Muzica 10 (1985): 7-8.
} 
traditions, to enriching the universal cultural patrimony, obtaining as such a well-deserved international prestige. In this artistic context [emphasis added], the $10^{\text {th }}$ edition of the George Enescu International Festival brings together the country's creative and performing forces, joined by ensembles and personalities from all over the world. ${ }^{40}$

During all three important phases in Communist Romania's foreign (and domestic) policy, the fact that musical life was subject to the party's strict control remains an unquestionable reality. Romania's sometimes better, sometimes less inspired performance in the part it played in the Cold War had, during these four decades, a decisive impact on the development of Romanian music and on its international visibility in particular. It was one of the undeniably ill-fated marks of Communist totalitarianism.

${ }^{40}$ Călinoiu, "Referatul prezentat de tov. Nicolae Călinoiu,” 2. 


\section{References:}

Albescu, Theodora. "Vara muzicală de la Taormina." Muzica 11 (1970): 37-39.

Bughici, Dumitru. "Note de călătorie." Muzica 11 (1970): 32-33.

Călinoiu, Nicolae. "Referatul prezentat de tov. Nicolae Călinoiu, directorul Direcției Muzicii din Consiliul Culturii și Educației Socialiste, la consfătuirea din 12 august 1971, privind repertoriul instituțiilor muzicale de spectacole și concerte pe stagiunea 1971-72." Muzica 9 (1971): 1-10.

Cosma, Octavian Lazăr. "Itinerar muzical american." Muzica 6 (1970): 37-42.

Cristian, Vasile. "Soli ai muzicii din țările prietene." Muzica 9 (1952): 83-86.

Deletant, Dennis. "România sub regimul comunist (decembrie 1947-decembrie 1989)." In Istoria României, edited by Mihai Bărbulescu, Dennis Deletant, Keith Hitchins, Șerban Papacostea, Pompiliu Teodor, 407-480. Bucharest: Editura Corint, 2012.

"Din alte țări." Muzica 2 (1953): 76-77.

"Din opiniile oaspeților străini la festival." Muzica 10 (1985): 7-8.

Georgescu, George. "Să promovăm mai departe arta și cultura noastră nouă socialistă." Muzica 12 (1962): 15.

Gheciu, Radu. "Cu prilejul vizitei tovarășului Nicolae Ceaușescu, Președintele Consiliului de Stat al R.S.România în Franța: Muzică românească la posturile franceze de Radio." Muzica 8 (1970): 4.

Gheorghiu, Virgil. "Impresii din Republica Democrată Germană.” Muzica 12 (1952): 147-149.
Hoffman, Alfred. "Vizită artistică în Grecia." Muzica 11 (1970): 28-32.

Jerea, Hilda. "Festivalul muzicii bulgare." Muzica 9 (1952): 97-103.

Mendelsohn, Alfred. "Impresii din Praga." Muzica 9 (1952): 104-106.

Oțeanu, Smaranda. "Secvențe muzicale Iugoslave." Muzica, 11 (1970): 35-37.

Sandu-Dediu, Valentina. Muzica românească între 1944-2000. Bucharest: Editura Muzicală, 2002.

"Săptămâna Muzicii Românești." Muzica 5 (1952): 20.

Sava, Iosif. "Anchetă internațională: Drumurile muzicii contemporane." Muzica 4 (1968): 1-9.

Sbârcea, George. "Turneul Ansamblului de operă din Phenian." Muzica 4 (1972): 26-27.

Solovyov-Sedoi, Vasily Pavlovich. "Cuvântarea compozitorului V.P. SolovievSedoi ținută în ședința din 29.IX.1951 a Plenarei Uniunii Compozitorilor din R.P.R." Muzica 5 (1952): 62-65.

Stalin, Joseph Vissarionovich. "Răspunsurile tovarăşului I. V. Stalin la întrebările primite din partea corespondentului diplomatic al lui New York Times, James Reston, la 21 decembrie 1952." Muzica 12 (1952): 9.

Vancea, Zeno, Anatol Vieru. "Muzica românească în context mondial - convorbire cu Zeno Vancea și Anatol Vieru." Muzica 4 (1968): 20-23.

Vescan, Mauriciu. "Aspecte din viața muzicală a capitalei Uniunii Sovietice." Muzica 12 (1952): 143-146. 
Vieru, Anatol. "Succesele muzicii noastre în urma însușirii principiilor Hotărârii CC al PC (b./bolșevic) asupra operei Marea prietenie de V. Muradeli." Muzica 1 (1950): $10-17$.
Zakharov, Vladimir Grigoryevich. "Cuvântarea compozitorului V.G. Zaharov ținută în ședința din 28.IX.1951 a Plenarei Uniunii Compozitorilor din R.P.R." Muzica 5 (1952): 59-61. 


\title{
10. \\ "Ideologically progressive art" meets Western avant-garde
}

\author{
Lenka Křupková
}

Shortly after Victorious February-the 1948 Communist coup détat that put a definitive end to the democratic Masaryk era of Czechoslovakia-Prague hosted the Second International Congress of Composers and Music Critics. Its final proclamation, entitled the Prague Manifesto, became the basis of the future direction of musical culture in Communist countries. The Manifesto called for a way out of the deep crisis in music and musical life of the day. Classical music was criticized for excessive individualism, subjectivity, complexity and artificial arrangement of form. Both classical and popular music represented "two sides of the same harmful cultural state," meaning the state of leveling cosmopolitanism. Participants in the congress officially joined the struggle against formalism in music, announced by Andrei Alexandrovich Zhdanov in his address to the congress of the USSR All-Union Communist Party (Vsesoyuznaya Kommunisticheskaya Partiya (Bolshevikov)) in February 1948. In September the same year, the first Working Congress of Composers and Musicologists was held in Prague, following up on the conclusions of the international congress and declaring the political role of music, which henceforth should seek creative support in the principles of Socialist Realism. The newly established Union of Czechoslovak Composers (UCC), closely tied to the ruling Communist Party, became the governing body for the implementation of Zhdanov's principles. The Union held sufficient financial assets and decision-making authority, and its directives declared the "value of a work of art"-it's thought content, progressiveness, folk character and comprehensibility. The organizational structure developed over the course of the first decade, only to be finally subdivided into three sections-composer, musicological, and performer sections-while the field offices in major Czech and Slovak towns and cities were being established. An independent Union of Slovak Composers also existed as of 1955. The Union's voice was the only music periodical published at the time, Hudebni rozhledy (Musical Perspectives), through which the general public was meant to be formed as regards their ideas and taste. ${ }^{1}$ While the first post-Victorious February years were

1 Petar Zapletal, “Československý svaz skladatelů [Union of Czechoslovak Composers]," Český hudební slovník osob a institucí [online], last modified March 7, 2013, http://www.ceskyhudebnislovnik.cz/slovnik/index.php?option=com_mdictionary\&task=record.record_detail\&id=5881. 
focused on establishing domestic musical culture and the application of ideological themes in music, external presentation of the ideologically approved musical culture of the young people's state became the Union's mission as of the mid-1950s. The Union organized tours of artists abroad, initially to allied socialist countries. Later, the Union began sending its ideologically proven officials to the West. And it was there that ideologically progressive art was directly confronted with Western musical avant-garde. This article will outline how this encounter with the international post-war musical avant-garde was reflected by the official representatives of Czechoslovak musical culture in the 1950s and 1960s. Key sources of information include, in particular, archival documents unprocessed to date, among which I was able to use the minutes of the meetings of the Central Committee of the Union of Czechoslovak Composers. Their authenticity is confirmed by verbatim stenographic notation of the main officials' speeches and discussions of other members, revealing the mindset of the time as well as individual qualities. Other available sources include reports from international conferences and contemporary music festivals, published in Hudební rozhledy.

In Czechoslovakia, the first doubts about the validity of Zhdanov's principles arose even prior to the fatal twentieth Congress of the Communist Party of the Soviet Union, after which gradual de-Stalinization and overall relief of tensions also took place in Czechoslovakia. The introductory speech at the Extraordinary meeting of the Central Committee of the Union of Czechoslovak Composers in 1955 was given by Antonín Sychra, a musicologist and aesthetician, but also an influential official and ideologist of the Union. In the speech, he voiced an opinion, apparently widespread among Union members, that Socialist Realism was a regressive and dubious approach and an oversimplification. Sychra expressed this using a metaphor, also somewhat simplistic, "that in the time of jet airplanes we force composers to ride in stage coaches." He argued that socialist enthusiastic themes were receding into the background, that composers were beginning to experiment with music procedures, and that there was talk about the need to turn to the West. Sychra had concerns about the declining interest in people's artistic upbringing, this being the main mission and pillar of the Union's activities. At the same time, he announced a strategy to penetrate into the West, which involved any and all places "where they have not yet taken us into account, or refused to do so," that is, composers' festivals in Edinburgh, Lucerne, Brussels, etc., or scientific congresses where no Czechoslovak representatives had been invited so far. ${ }^{2}$

In 1957, the Union succeeded in re-establishing Czechoslovak membership in the International Society for Contemporary Music (ISCM), suspended after the Communist coup, while, at the same time, musicologists joined the French Société

2 National Archives [Národní archiv (NA)], Union of Czechoslovak Composers [Svaz československých skladatelü], box No. 9, Stenographic minutes of the Extraordinary meeting of the UCC's Central Committee, September 21, 1955, Antonín Sychra's paper presented at the Extraordinary meeting of the UCC's Central Committee. 
Internationale de Musicologie and the German Gesellschaft für Musikforschung. This participation was defended within the Union as a possibility to establish a critical attitude toward the West and strengthen the position on the social function of music, although criticism of this international direction grew stronger, especially among officials closely associated with communist ideology. They stated that while "middle-class, decadent music" had been silenced after 1948, revisionist tendencies were now growing: competing with the West, composers were taking more interest in composing techniques than in whether or not their music served the people. ${ }^{3}$

Officials therefore endeavored to express criticism of the artistic experiences from their trips abroad. Upon returning from his first trip to a festival organized by the ISCM in Zurich in June 1957, Sychra denounced the performance of Schoenberg's opera Moses and Aaron, which he saw as a metaphor for the crisis of Western civilization. Music must be communicable and establish a link with something that resonates in people, Sychra wrote for Hudebni rozhledy, adding that Schoenberg is unable to express positive qualities of life, he is only able to "instinctively heat up and harrow." ${ }^{4}$ An ideologically similar evaluation of a man living in the conviction of socialist optimism, in which art serves the masses, was expressed by Zdeněk Bartoš, who attended the next edition of the ISCM festival in Venice. He concluded his paper with the following statement: "No, I have not brought enthusiasm and joy from the festival of contemporary music in Venice, or even the exaltation I experience upon encountering any great work of art." Bartoš was particularly critical of the closing concert, a digest from the works of Igor Stravinsky, conducted by the composer himself, which opened with Stravinsky's sacred cantata Threni. The Union's official was embittered by the subjects of the works dealing with the four last things of man: "It was the very bleakness of this music, played this night as well as some previous nights, that-despite expressing joy-is grey, desolate and sad. Who is it intended for? Where is the human sentiment? Where is this art heading, what does it want, whom does it serve?" 5

The peak international event of 1958 was the seventh Congress of the International Musicological Society in Cologne. The Czechoslovak delegation was once again led by Antonín Sychra and included, among others, Jaroslav Jiránek, musicologist, editor-in-chief of Hudebni rozhledy and member of the Union's presidium, whose communist conviction was close to fanaticism at the time. Jiránek

\footnotetext{
3 NA, UCC, box No. 13, Stenographic minutes of the Meeting of the UCC's Central Committee, February 15, 1958, Main paper of UCC secretary Antonín Hořejši presented at the meeting of the UCC's Central Committee.

4 Antonín Sychra, "Experiment nebo umění? Na okraj festivalu Mezinárodní společnosti pro soudobou hudbu v Curychu [Experiment or art? On the margins of the festival of the International Society for Contemporary Music in Zurich]," Hudební rozhledy 11 (1957): 608-609.

5 Jan Zdeněk Bartoš, "Festival soudobé hudby v Benátkách [Festival of contemporary music in Venice]," Hudební rozhledy 11 (1958): 796-797.
} 
authored a detailed report on the conference, published in the magazine. ${ }^{6}$ Not all who wanted to attend the congress succeeded; the congress organizers rejected, for instance, a paper by the Union's secretary, Antonín Hořejš, entitled “The influence of the masses on musical life in Czechoslovakia," which Jiránek saw as relating to the overall atmosphere and ideological direction of the host country. Jiránek also harshly criticized the general concept of Western musicology of the time, being infiltrated, in his opinion, by a spirit of individualism that brought "what is repugnant to us almost instinctively, this personally conceived 'splendid isolation,' called 'private' by the Brits with a grain of pride, which for us, socialist people, actually means the deep solitude of man-the individual." 7 Jiránek took a feeling from the congress that historiography only paid attention to the study of the Gregorian chant and then to dodecaphonic music, but disregarded what was in between, i.e. the essence of European culture, in his opinion. Nevertheless, Jiránek was aware of the need to cooperate with Western musicology, albeit stranded in shallow water that could only be surmounted "through creatively experienced and understood Marxist gnoseology." A discussion that flared up during a visit to the Electronic Music Studio of the West German Radio in Cologne was described as a small victory of "rational" Marxist musicology by Jiránek as well as another congress participant, Antonín Sychra. ${ }^{8}$ The studio's production was demonstrated by its founder and director Herbert Eimert. Although the description of this discussion by the Czechoslovak delegates is somewhat inconsistent (their language proficiency and the resulting level of understanding clearly differed), it is apparent that there was a clash between T. W. Adorno and Karlheinz Stockhausen on the one hand and East German musicologists Harry Goldschmidt and Georg Knepler on the other. Stockhausen was allegedly trying to persuade the others that people who listen to his music, even those who reject it, widely understand its meaning-for instance, the expression of abhorrence of nuclear war. Stockhausen was faced with reproaches that the means he and similar composers were using to express fear were incomprehensible to other people, but that he was indifferent to this fact. Knepler and Goldschmidt reportedly succeeded in disproving Adorno's belief that electronic music is a way of free expression of artistic individuals in the free world, and the argument of the East German musicologist was well received by West German students. This was allegedly the moment that flabbergasted Adorno so much that he expressed very deep regret about the fact that even in the Western, free world, there were people who do not understand the right of an artist to individual freedom of expression and who have in them a seed of susceptibility to totalitarian regimes such as Nazism

\footnotetext{
6 Jaroslav Jiránek, "Kongres v Kolíně nad Rýnem [Congress in Cologne]," Hudební rozhledy 11 (1958): 608-613.

7 Ibid., 609.

8 See Sychra's paper at the $34^{\text {th }}$ Meeting of the UCC's Central Committee. NA, UCC, box No. 13, Stenographic minutes of the Meeting of the UCC's Central Committee, July 3, 1958.
} 
and Communism. Czech attendees interpreted this discussion patronizingly, with a feeling of ideological supremacy and convinced that the Western camp's spokesmen and advocates of electronic music were successfully put on the defensive. ${ }^{9}$ They ironically appreciated that Stockhausen, for instance, was trying to artistically react to the darker side of the Western world, but in a manner unacceptable to a socialist artist who never encountered decadence leading to decline. ${ }^{10}$

In his article, Jiránek also analyzed a festival concert with late tonal works of Schoenberg and Webern, Wolfgang Fortner's twelve-tone composition Mouvements for piano and orchestra, and Luigi Nono's Il canto sospezo. Jiránek's criticism was aimed predominantly at Fortner's composition, labeling it "formalist, abstractly grey, pitifully non-individual in the personal and ethnic sense." ${ }^{11}$ He believed such artistic expressions had to be condemned as "bourgeois formalism is programmatically esoteric and aristocratic, but in socialist conditions, there is no place for art that is not programmatically popular, democratic, and ambitious, one that does not intend to become a powerful social force of the socialist cultural revolution of the broad masses." Jiránek also condemned Nono's composition, undoubtedly compatible with communist ideology thanks to its anti-fascist subject, but in his view the reality represented was not rendered truthfully. The musical means used, i.e. a serial technique applied to the vocal component, resulted in the fact that many parts "are flatly repugnant, inhuman, disturbed," unsuitable for portraying the world of heroes. Jiránek was irritated by the rejection of the natural vocal technique as well as the "formalist deformation of the natural musical declamation." 12 The Union was very ambivalent toward this Italian composer. In the early 1960s, Luigi Nono expressed an interest in cooperating with Czech composers. The minutes of the Union's proceedings contain information about Nono's criticism, in which he stated that the Czechoslovak party insufficiently reflected the good political work of Italian Communists (Nono was a prominent representative of the Italian Communist Party). And conversely, the Union blamed the Italian composer for not recognizing the works of Czechoslovak composers. Václav Dobiáš, the Union's president and a consistent implementer of Socialist Realism ideas (his most famous work is a cantata entitled Build Up Your Country, Strengthen Peace), made the following statement after attending a meeting with Luigi Nono, during which Nono played his and Bruno Maderna's works: "We were dismayed by this music. His political views are entirely forward-looking, he sees everything around him in the right way, but the contradiction between his views and his music is beyond comprehension for us." 13

\footnotetext{
9 Jiránek, “Kongres v Kolíně nad Rýnem," 612.

10 Antonín Sychra's paper at the 34 ${ }^{\text {th }}$ Meeting of the UCC's Central Committee.

${ }^{11}$ Jiránek, "Kongres v Kolíně nad Rýnem," 611.

12 Ibid., 611-612.

${ }^{13}$ NA, UCC, box No. 3, Stenographic minutes of the $26^{\text {th }}$ meeting of the Presidium of the UCC's Central Committee, November 21, 1961.
} 


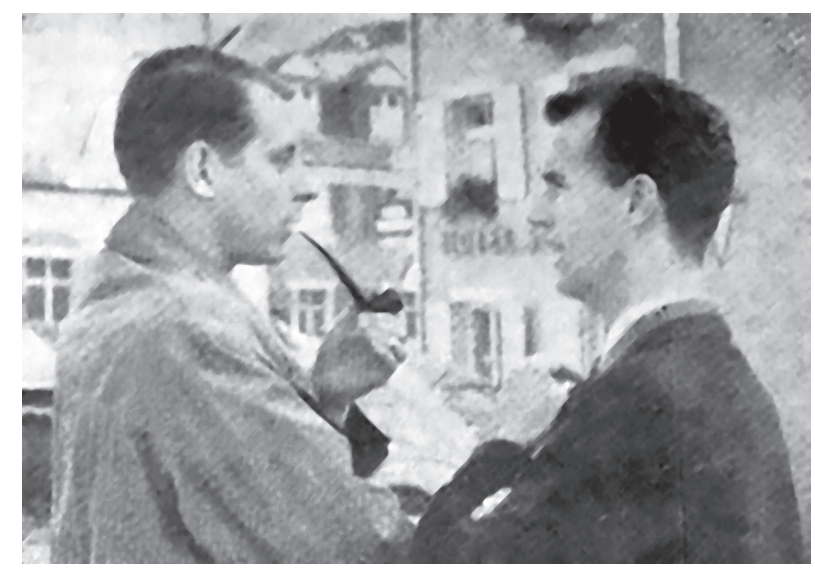

Figure 1. Karlheinz Stockhausen and Luigi Nono at the $7^{\text {th }}$ Congress of the International Musicological Society in Cologne. Reprint from Hudební rozhledy 11 (1958): 611.

The success of the Czechoslovak pavilion at the Brussels World Fair in 1958 opened the door abroad for Czechoslovak art, with touring of Czechoslovak orchestras and theatrical companies increasing in general. In his introductory speech at the $35^{\text {th }}$ meeting of the UCC's Central Committee, the Union's president Václav Dobiáš spoke about the growing interest in Czechoslovak music worldwide, admitting he was receiving requests from the US to send Czech works to be performed, and that he was a frequent guest at embassies of Western countries: "All of a sudden, they are interested in meeting and greeting you, even saying hello in Czech." Dobiáš also provided a political explanation to this change. In his opinion, if Western countries wanted to find a way to the socialist camp, Czechoslovakia as a partner was less dangerous for them than the Soviet Union. He further elaborated on his theory as follows: The West had lost its commercial outlet in socialist countries as they had become economically powerful and self-sufficient, and therefore the West has to resort to the ideological struggle. Dobiás provided an example of an occasion when a Czechoslovak cultural front entity "swallowed the bait given by the West." In the summer of 1958, Prague's National Theatre was invited to the Royal Opera in Brussels. "We thought: Brilliant, they must really like us, why is that? Maybe because some Belgians had been in a concentration camp with us." In the end, the entire undertaking was very unprofitable. "Comrades, we paid sixty francs a day for this generous gift." The invitation came for a period after the end of the season, a time when no one really attended opera, and the theatre was almost empty at the Czechoslovak performances, as Dobiáš explained the dishonest behavior of the Western institution to his Union colleagues. ${ }^{14}$

\footnotetext{
${ }_{14}$ NA, UCC, box No. 13, Stenographic minutes of the Meeting of the UCC's Central Committee, November 17,1958 . Introductory speech of the president of the UCC, Václav Dobiáš, at the $35^{\text {th }}$
} 
The Union's officials were required to report on the seamy side of Western culture, but also on the successful representation of the people's democratic culture, naturally motivated by efforts to curry favor with the governing body, the Communist Party, which funded the trips. In his account of the International Congress of the Canadian League of Composers, Dobiáš tried to convince readers of Hudebni rozhledy that his contribution to the discussion, in which he introduced the Union's activities to the Canadian audience and assured them of the Union's excellent economic possibilities, was a "bombshell," to use his own words. ${ }^{15} \mathrm{In}$ light of frequent complaints about budget problems discussed at the Union meetings, this international presentation by Dobiáš seems almost laughable.

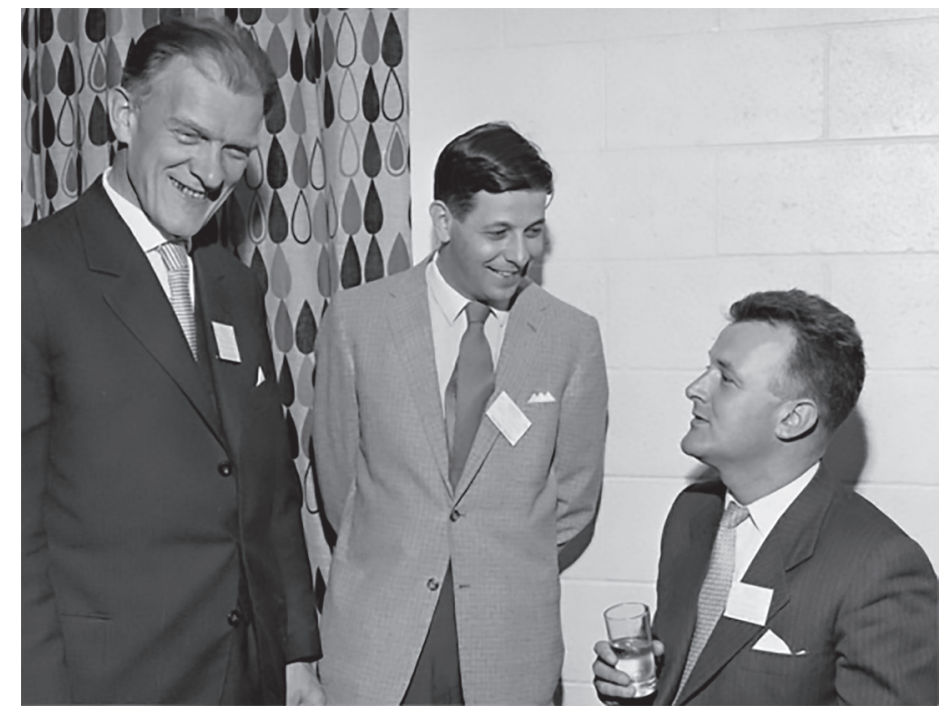

Figure 2. Václav Dobiáš (left) at the International Congress of the Canadian League of Composers (1960). National Archives, Fond of the Union of Czechoslovak Composers, box No. 3, sign. Dobiáš, folio 117.

The Union of Czechoslovak Composers nevertheless generously sponsored large delegations of its "observers" to the Warsaw Autumn festival that became a sort of Darmstadt for the people's democratic republics soon after its foundation in 1956. The festival, organized in a brotherly socialist country, distinctly departed from Zhdanov's doctrines from the very beginning, presenting the latest works of Western avant-garde composers. Even the Polish composing school broke the chains of Socialist Realism, and this fact was reflected in a very negative way by

meeting of the UCC's Central Committee in Brno.

15 "Na mezinárodním kongresu v Kanadě. Rozhovor s Václavem Dobiášem [At the international congress in Canada. Interview with Václav Dobiáš]," Hudební rozhledy 13 (1960): 721-724. 
the Union, this being documented by numerous critical texts published in Hudebni rozhledy. In the early 1960s, even the Union's officials had to admit that a lack of knowledge of the new composition techniques was becoming a serious handicap for Czech and Slovak composers, especially when meeting Polish composers, as one attendee informed his colleagues: "The Poles take pride that their works are being performed in the West, and they view us as uneducated and obsolete. They don't see us as their partners, and this became apparent in the discussions." ${ }^{16} \mathrm{He}$ tried to persuade the others that it was a mistake not to be able to educate Czechoslovak musicians in these directions, and that if this music were discussed to a greater extent, it would cease to be a forbidden fruit. The view that composers should be allowed to attend the festival in Warsaw, but also the one in Darmstadt, was also voiced at the Union's meeting in 1961.

The process of gradual loosening of the rigid 1960s atmosphere was slow and reluctant in the magazine Hudebni rozhledy, i.e. the Union's official mouthpiece. This decade also saw a sharp increase in the number of trips abroad, as indicated, for instance, in the plan of such trips for 1963. Its caompilation and approval had to be preceded by numerous negotiations with the relevant officials of both the Communist Party and the Union in the individual sections. ${ }^{17}$ The Union's officials increasingly talked about the importance of maintaining international contacts, ensuring Czechoslovak participation in international congresses and seminars, delegating judges to international competitions, and building an "outward musical offensive," to use the rhetoric of the time. ${ }^{18}$ The West also played a major role here. The composers' interest, however, in presentation abroad and gaining professional experience was limited by the low foreign exchange resources available to the Union, but primarily by the complicated approval process, as the trip of each delegation or individual members had to be decided by the supreme party body, the Central Committee of the Communist Party of Czechoslovakia. Within the 40-year era

\footnotetext{
${ }^{16}$ NA, UCC, box No. 3 , Minutes of the $23^{\text {rd }}$ meeting of the Presidium of the UCC's Central Committee, September 11, 1961.

17 NA, UCC, box No. 4, Minutes of the meeting of the Presidium of the UCC's Central Committee, November 6, 1961.

${ }^{18}$ For instance, in 1963, the Union sent the following works of Czech composers to the ISCM competition held in Copenhagen: Jan Rychlík's African Cycle, Jarmil Burghauser's Seven Reliefs, Viktor Kalabis's String Quartet No. 2, Josef Berg's Nonet. Slovak compositions included Peter Kolman's String Quartet and Miroslav Bázlik's Five Songs on Chinese Poetry. The Union also attempted to present Czech composers in the US, an effort to be arranged by Miroslav Košler, a conductor who then worked as assistant to Leonard Bernstein in New York (the following selection of works was sent to the US: Lubort Bárta: Piano Concerto; Svatopluk Havelka: Symphony; Otmar Mácha: Night and Hope; Vladimír Sommer: Antigone; Jindřich Feld: Concerto for Flute and Orchestra; Viktor Kalabis: Symphony No. 2; Jaromír Podešva: Symphony No. 2. See NA, UCC, box No. 4, Report on the activities of the Presidium of the UCC's Central Committee between the Fourth and Fifth Meeting of the Central Committee, not dated [1963].
} 
of the Communist regime in Czechoslovakia, the 1960s were a period during which ideological arguments in art receded into the background, music became a genuine instrument of diplomacy and a tool to promote closer ties between the two worlds separated by the Iron Curtain. The democratization process in society, culminating in the Prague Spring of 1968, was violently cut short, however, by the invasion of Warsaw Pact forces. The so-called normalization, which took place in the 1970s, once again returned Czechoslovak musical culture to isolation. The Union's officials became increasingly conscious of the lack of continuity in Czechoslovak contemporary music in the face of the world stage, realizing it was pointless to ideologically comment on events occurring in Western New Music and continually contrast it with "our healthy core." 


\section{Primary sources:}

National Archives (NA) (Prague): Union of Czechoslovak Composers

\section{References:}

Bartoš, Jan Zdeněk. "Festival soudobé Sychra, Antonín. "Experiment nebo umění? hudby v Benátkách." Hudební rozhledy 11 (1958): 796-797.

Jiránek, Jaroslav. "Kongres v Kolíně nad Rýnem.” Hudební rozhledy 11 (1958): 608-613.

"Na mezinárodním kongresu v Kanadě. Rozhovor s Václavem Dobiášem." Hudební rozhledy 13 (1960): 721-724.

Na okraj festivalu Mezinárodní společnosti pro soudobou hudbu v Curychu." Hudební rozhledy 10 (1957): 607-609.

Zapletal, Petar. "Československý svaz skladatelů." Český hudební slovník osob a institucí [online], last modified March 7, 2013, http://www.ceskyhudebnislovnik.cz/ slovnik/index.php?option=com_mdictionary\&task=record.record_detail\&id=5881. 


\section{Part III. \\ Music as a Means of Cultural Diplomacy}





\title{
Music and cultural diplomacy: Presentation of the "new Yugoslavia" in France after $1945^{*}$
}

\author{
Aleksandra Kolaković
}

Cultural diplomacy was a powerful tool even after the WWII, which brought a new political composition in the world and a redistribution of power. It is believed that France managed to remain an important international actor in this period due to well-developed cultural diplomacy. ${ }^{1}$ Also, the new Communist rule in Yugoslavia, in addition to consolidating power in the country, sought to develop propaganda abroad, and especially, in the countries of the Western Europe. It was a setting for the new Yugoslav diplomacy and a place in international relations that Tito's Yugoslavia needed following the split with the USSR and the Cold War conflicts. Instruments of cultural diplomacy were not only intellectual and scholarly relations, lectures, translating books, but also art exhibitions, plays, films and music. The department dealing with foreign relations counted primarily on folklore ensembles (in form of cultural and artistic societies-kulturno-umetnička društva) as the most representative, and also supported performances by amateur choirs. Music was considered a suitable means of showing the cultural level of a state, which also goes for the new socialist Yugoslavia. The aim was to introduce the new country and to improve its international reputation. State-building, organization of the system of the government, consolidation of power and participation in international relations called for specific and complex tasks of the Yugoslav diplomacy. Therefore, there are also specifics in the field of cultural diplomacy, including the use of music, which are typical of the Yugoslav use of soft power.

France-as a Western European country where Yugoslav communists cooperated with the Communist Party of France (KPF) in spreading propaganda in the diaspora and in presenting the new country to the world-was particularly relevant

\footnotetext{
* This paper is a part of the project activities of the Institute for Political Studies, supported by the Ministry of Education, Science and Technological Development of the Republic of Serbia.

1 Fransoa Šobe, Loren Marten, Međunarodni kulturni odnosi [International Cultural Relations] (Belgrade: Clio, 2014), 16.
} 
to the new Yugoslav regime. ${ }^{2}$ Moreover, collaboration between the French and the Serbian (Yugoslav) intellectuals, ${ }^{3}$ which had a history of more than a century, entered a new phase after the WWII, marked by party affiliation from the period of the Spanish Civil War, when the Yugoslav National Committee for Assistance to Republican Spain operated in Paris until the occupation of France and the French resistance movement. ${ }^{4}$ The first Yugoslav diplomats were also selected from the ranks of non-communists, especially in the countries of the West, primarily due to a shortage of communist staff. ${ }^{5}$ It was also believed that these individuals would contribute to building of a positive image of the new Yugoslavia in a period of strained relations with Western powers due to the northwestern borders of the country and relations with the Soviet Union, considering the turnaround enacted by the Cominform Resolution of 1948 and later in the Cold War. ${ }^{6}$ These relations

2 Aleksandra Kolaković, "Présentation de la nouvelle Yougoslavie en France de 1945 à 1973. Diplomatie et culture [Presentation of the new Yugoslavia in France from 1945 to 1973. Diplomacy and culture]," in La France et la Serbe: Les défis de l'amitié éternelle, edited by Aleksandra Kolaković, Sacha Markovic (Belgrade: Institut za političke studije, 2020, forthcoming).

3 Fadil Ekmečić, Poslednjih sto godina Jugoslovena u Francuskoj. La Presence Yougoslave en France depuis 100 ans (exposé préliminaire, thèse et chronologie succinte) [The Presence of Yugoslavs in France in the Last Hundred Years (opening statement, thesis and chronology)] (Paris: Yougo-France, 1981), 30-34; Slavenko Terzić (Ed.), Jugoslovensko-francuski odnosi: povodom 150 godina od otvaranja prvog francuskog konzulata $u$ Srbiji [Yugoslav-French Relations: On the Occasion of the $150^{\text {th }}$ Anniversary of the Opening of the First French Consulate in Serbia] (Belgrade: Istorijski institut, 1990); Mihailo Pavlović, Jelena Novaković, Srpsko-francuski odnosi 1904-2004 [Serbian-French relations 1904-2004] (Belgrade: Arhiv Srbije, 2004); Dušan T. Bataković, Une alliance atypique. Les relations franco-serbes 1878-1940 [An Atypical Alliance. Serbian-French Relations 1878-1940] (Belgrade: Balkanološki institut SANU, 2010); Dušan T. Bataković, "Francuski uticaji u Srbiji 1835-1914. Četiri generacije Parizlija [The French influence in Serbia 1835-1914. Four generations of Parisians]," Zbornik Matice srpske za istoriju 57 (1997): 73-95; Stanislav Sretenović, Francuska i Kraljevina Srba, Hrvata i Slovenaca 1919-1929 [France and the Kingdom of Serbs, Croats and Slovenes 1919-1929] (Belgrade: Institut za savremenu istoriju, 2009); Aleksandra Kolaković, $U$ službi otadžbine: saradnja francuskih $i$ srpskih intelektualaca [In the Service of the Homeland: The Collaboration of French and Serbian Intellectuals] (Belgrade: Institut za političke studije, 2016); Aleksandra Kolaković, "War and Propaganda in 1915: French Intellectuals and Actualization of Serbian Issues," in The Great War in 1915, edited by Dalibor Denda, Christian Ortner (Belgrade, Vienna: Institut za strategijska istraživanja, 2017), 330-352.

4 Savo Pešić, "Komunistička partija Jugoslavije i španski građanski rat [The Communist Party of Yugoslavia and the Spanish Civil War]," Vojno-istorijski glasnik 2 (1986): 261-276; Hervé Lemesle, "Les volontaires yougoslaves en Espagne républicaine: des sources pour une étude prosopographique [Yugoslav volunteers in republican Spain: sources for a prosographic study]," Matériaux pour l'histoire de notre temps 123/124 (2017): 50-58.

5 Slobodan Selinić, Partija i diplomatija u Jugoslaviji 1945-1952 [The Party and diplomacy in Yugoslavia 1945-1952] (Belgrade: Institut za noviju istoriju, 2013), 63-91.

6 Le cas Yougoslave: intéresse l'opinion publique [The Yugoslav case: the examination of public opinion] (Toulouse: Association des jeunes des brigades en Yougoslavie, 1948); Vladimir Dedijer, The battle Stalin lost: memoirs of Yugoslavia 1948-1953 (New York: Grosset \& Dunlap, 1972); Čedomir Štrbac, Jugoslavija i odnosi između socijalističkih zemalja: sukob KPJ i Informbiroa [Yugoslavia and the relations between socialist countries: the conflict between the CPY and Cominform] (Belgrade: 
were achieved through Yugoslav participants in the French resistance movement and played a role in the 1948 crisis. ${ }^{7}$ At the same time, efforts were made to collaborate with prominent individuals from the cultural sphere in France, primarily literature, such as Louis Aragon. ${ }^{8}$ Also, the new Yugoslavia put great importance on the power of the press. Therefore, it sought to place affirmative information on Yugoslavia and Tito, not only through French newspapers but also by supporting the publication of newspapers, in French and Serbo-Croatian, for the Yugoslav diaspora and the French public. ${ }^{9}$ The use of soft power depended on diplomats in Paris and official authorities in Yugoslavia. However, key diplomatic actions, including those involving the use of music, were designed in Belgrade and then carried out in France. It is important to explore the objectives of cultural diplomacy, as well as the achievements of thus designed public diplomacy. In this paper, we will limit ourselves and focus on research concerning the use of music in the cultural diplomacy of the new Yugoslavia in France in the period from 1945 to the founding of the Yugoslav Cultural Center in Paris, which was part of a new strategic plan for Yugoslavia's cultural diplomacy.

\section{Music of new Yugoslavia in Paris: \\ The first tones of cultural diplomacy}

The importance of France is evident from the fact that in April 1945 Marko Ristic was made ambassador-he was a French student, surrealist poet, and great expert in French culture and art. Since the interwar period, Ristić and his wife Jelica Živadinović (Ševa Ristić) had been well known in artistic salons of Paris. ${ }^{10}$ As a

Prosveta, 1984); Dragan Bogetić, "Saradnja Jugoslavije i zapada u vreme sukoba sa Kominformom (1952-1955) [The collaboration of Yugoslavia and the West during the conflict with the Cominform (1952-1955)]," in Velike sile i male države u Hladnom ratu: slučaj Jugoslavije, edited by Ljubodrag Dimić (Belgrade, London: Filozofski fakultet Beograd, Katedra za istoriju Jugoslavije, Arhiv Srbije i Crne Gore, Institut za noviju istoriju Srbije, Centar za istraživanja hladnog rata LST, 2005), 43-62.

7 Ekmečić, Poslednjih sto godina, 18.

8 Ibid.

9 Aleksandra Kolaković, "Serbian Press in France during the 20 $0^{\text {th }}$ Century: Among the Cultural Diplomacy and the Information on the Diaspora," Les Cahiers balkaniques 47 (2020): 139-154.

10 The first encounter between Marko Ristić and André Breton, as well as other surrealists Paul Éluard and Louis Aragon, took place in Paris in 1926. This year was also a turning point for surrealism, as it expanded into political engagement. Surrealists began to react to the political order and fight against colonialism, responding to social, artistic and philosophical developments, phenomena and processes of the time. When Breton gathered a surrealist group in the Parisian cafe Prophet in 1929, Marko Ristić was invited. It is also worth noting that this point in French surrealism marked the beginning of the era of Surrealism in the service of the revolution. See: Marko Ristić, Književna politika: članci i pamfleti [Literary politics: articles and pamphlets] (Belgrade: Prosveta, 1952); Marko Ristić, Politička književnost (za ovu Jugoslaviju) 1944-1958 [Political literature (for this Yugoslavia) 1944-1958] (Sarajevo: Oslobođenje, 1977); Marko Ristić, Diplomatski spisi (Belgrade: Prosveta, 1996). 
friend of prominent French figures, Marko Ristić was a suitable person for diplomatic activities in France. As a non-Communist ambassador, Ristić went through tribulations that stemmed from relations with embassy employees who did not always understand how cultural exchange and cooperation with the French work. These circumstances were also often considered potentially dangerous-for fear of espionage. This reflected in the nature and reach of his initiatives. Ristić was ambassador to France in the difficult first post-war period of 1945-1951. Upon his arrival in France, he said that he was honored and proud to be the ambassador to France, "a country that has always been dear to us [...], the richness of its culture and the freedom of its people-it was a source of hope, encouragement and inspiration [for the Serbian and Yugoslav people]." ${ }^{11}$ Ristić's idea was to pay special attention to cooperation with prominent French intellectuals. ${ }^{12}$ This was also the approach pursued in the cultural diplomacy of the Kingdom of Serbia and the Kingdom of Yugoslavia. ${ }^{13}$

In addition to Ristić, Vuk Dragović, press advisor and former journalist of Politika, also influenced the implementation of cultural diplomacy in those first post-war years. ${ }^{14}$ Thanks to Ristić and Dragović, whose wife Marina Olenjina Dragović was a prima ballerina at the Belgrade National Theater, Yugoslav propaganda in France reemerged and began to use music for diplomatic purposes. The use of sound in diplomatic activities in France started as one would expect, with folk music and dancing. Already in 1947, a 15-strong girls' folk group of Yugoslav expatriates was founded in Paris, led by Marina Olenjina Dragović. ${ }^{15}$ The group was also sponsored by the ambassador's wife Jelica Ristić. In January 1948, the group performed at an event at the Hôtel Lutetia. ${ }^{16}$ The hotel, whose architectural style went from Art Nouveau to Art Déco since it opened in 1910, was a regular

\footnotetext{
${ }^{11}$ Miladin Milošević, "Dolazak u Pariz prvog ambasadora Nove Jugoslavije [First ambassador of new Yugoslavia comes to Paris]," in Srpsko-francuski odnosi 1904-2004 (Belgrade: Društvo za kulturnu saradnju Francuska Srbija, Arhiv Srbije, 2005), 123-131; Slobodan Selinić, "Ambasador nekomunista i partijska diplomatija. Marko Ristić u Parizu 1945-1951 [A non-communist ambassador and party diplomacy. Marko Ristić in Paris 1945-1951],” Tokovi istorije 2 (2012): 144-145. ${ }^{12}$ Diplomatic Archives of the Ministry of Foreign Affairs of the Republic of Serbia [Diplomatski arhiv Ministarstva spoljnih poslova Republike Srbije (DAMSPRS)], 1948, France, 48, 12, VII, 48/172, confidential No. 1169, telegram, Ristić, Embassy-MFA, Paris, April 14, 1948.

${ }^{13}$ Aleksandra Kolaković, "Kultura i diplomatija: Francuska i Srbija [Culture and diplomacy: France and Serbia]," in Kulture u dijalogu - Cultures in Dialogue, Cultural Diplomacy and Libraries, Vol. 3, edited by Aleksandra Vraneš, Ljiljana Marković (Belgrade: Filološki fakultet, 2013), 101-122.

14 Selinić, Partija i diplomatija, 218-239.

${ }^{15}$ Ekmečić, Poslednjih sto godina, 67.

${ }^{16}$ How prestigious it was to present Yugoslavia at this hotel, where exhibitions, events and lectures were often organized, could be illustrated by the fact that general de Gaulle was a regular guest there. He spent his honeymoon in this building, as well as the night before leaving for England, when he even forgot his luggage, and the suitcase was kept until his return. See Pierre Assouline, Lutetia (Paris, Gallimard, 2005).
} 
gathering point for artists, intellectuals, politicians and diplomats. Picasso and Matisse were guests, as well the famous Josephine Becker, and the hotel became a bastion of jazz music in France. ${ }^{17}$ With all this in mind, it is obvious that very much was expected from the idea of introducing the new state through music.

In June 1948, the same girls' folk group also performed at the Yugoslav Evening as part of the art exhibition of the International Federation of Women. This is a good example that shows how Paris served as venue of cultural diplomatic activities within the framework of international organizations. Music spoke a universal language in the sphere of cultural diplomacy, especially in a city like Paris, where different cultures merged. In the same year, the Choir of the Serbian Students' Association in France participated in a festival in Paris (June 27, 1948), and later in the well-known French tourist resort of Aix-le-Bains (July 25, 1948). ${ }^{18}$ In addition to the capital, cities in inland France were also selected for the promotion of Yugoslav music. Also, it can be noted that already in 1948, new Yugoslav diplomacy combined tourism with music in the context of cultural diplomacy. Furthermore, the aforementioned choir also collaborated with l'Alliance française (the French Alliance) in whose events it participated. ${ }^{19}$ This expanded the Yugoslav front of propaganda. It was of particular importance that Radio Paris broadcast Serbian songs performed by the choir on September 29 and October 28 that year.

Most cultural events, which initially involved folk groups and choirs formed in France (not groups coming from Yugoslavia), were aimed at the children of Yugoslav expatriates in France, but also formed the basis of further activities for performing cultural events, which were also supported by the France-Yugoslavia Association, established by both the French and the Serbs. This association was banned after the Cominform Resolution, but after 1949 several other associations were formed to pursue a similar mission. ${ }^{20}$ In addition to Yugoslavs, French participants also attended these cultural events, although documents do not record precise information as to their number. Certainly, there was noticeable propaganda activity in 1948, which could be directly linked to the Cominform Resolution. Moreover, inland France was also a field of numerous operations through the France-Yugoslavia Association. And again, the presentation of folk music and dancing was the primary activity. Nevertheless, diplomats were not always satisfied

\footnotetext{
17 Ekmečić, Poslednjih sto godina, 38.

18 Ibid., 70.

${ }^{19}$ L'Alliance française was as an auxiliary actor in French cultural diplomacy. It specifically targeted countries where the official state activities of cultural diplomacy and cultural cooperation had not provided satisfactory results. See Šobe, Marten, Međunarodni kulturni odnosi, 157-160.

${ }^{20}$ Archives of the Ministry of Foreign Affairs [Archives du ministère des Affaires étrangères (AMAE)], Z Europe Yugoslavia [Europe Yougoslavie], 1944-1949, Z 510-1, Yugoslavs in France; DAMSPRS, 1948, France - 9, 6, 47/247, telegram, No. 426688, Simić MFA - Embassy Paris, January 2, 1948; ibid., 47/248, confidential telegram, No. 645, February 26,1948.
} 
with these activities, which can be seen from the dispatch of the Consulate General of the People's Republic in Marseille from 1948, which reports on a party held by a branch of the Franco-Yugoslav Association in Lyon. At the party, which was supposed to have "the character of a manifestation of friendship between Yugoslavia and France, and be an opportunity to speak about Yugoslavia," no one from the audience, consisting exclusively of younger working women, knew who the organizers were nor did they know at least that it was a France-Yugoslavia event. Instead, they came to the party to have fun, as the usual audience of this place does. It was assessed that such an event "does not fit the reputation" of the Association, "that the aim is missed," and "that the Association must take a different direction." 21 The lack of funds invested in cultural diplomacy and poor affiliation with important figures were the main problems of these activities. Also, music was only one aspect. Moreover, it was not easy for cultural diplomacy of the new Yugoslavia to achieve results given the complicated bilateral and multilateral relations and international circumstances.

A new period in diplomatic relations:

Music and Tito's first official visit to France

During his service in Paris between 1950 and 1955, the next Ambassador of Yugoslavia to France, Srđan Srđa Prica-a lawyer by education, a member of the Communist Party since 1925, and a veteran of the Spanish Civil War resident in the United States who joined the Yugoslav diplomacy at the suggestion of Edvard Kardelj-also used the tunes of diplomatic notes. ${ }^{22}$ Yugoslavia's national holidays were a special occasion for events with a musical program. These events were organized by Yugoslav emigrant associations, but with the assistance of the Yugoslav Embassy. One such noteworthy manifestation was held on Republic Day, November 29, 1950, prepared by the Brotherhood and Unity Association. It took place in the heart of Paris, near the Grand Palais at the beginning of the Champs-Élysées fields, where one of the most luxurious boutique hotels, La Maison des Centraliens, stands today. At the end of the same year, the Yugoslav Singing and Support Society Jadran held a performance in Freyming-Merlebach, on the German border in northeast France. ${ }^{23}$ By 1952, Yugoslav cultural propaganda partly contributed to the creation of general conditions for the first guest appearances of prominent Yugoslav artists and musicians in France.

${ }^{21}$ DAMSPRS, 1948, France, 50, No. 359, Annual report of the Consulate General in Marseille.

22 Enciklopedija Jugoslavije [Encyclopaedia of Yugoslavia], Vol. 6. (Zagreb: Jugoslovenski leksikografski zavod, 1965); "Ambasador Srđa Prica srdačno dočekan u Lionu [Ambassador Srđa Prica warmly greeted in Lyon],” Politika (June 11, 1952): 5.

${ }^{23}$ Ekmečić, Poslednjih sto godina, 78. 
Clearly, culture was the chosen as a path to warm up the Franco-Yugoslav relations strained by several elements: the presence of nearly 14,000 Serbian political emigrants in France (monarchists, supporters of the Karađorđević dynasty, former members of the Chetnik movement, Draža Mihailovićs sympathizers and dissidents), the relationship between de Gaulle and Tito, as well as the Cominform Resolution, when mistrust between the French and Serbian communists came into the spotlight. Yugoslav diplomacy believed that music was one of the means by which relations between France and Yugoslavia could be improved. From July 15 to 17, 1952, the Ballet of the Belgrade National Theater performed in Paris for the first time (with 76-member ensemble). The prestigious venue of the Palais de Chaillot itself was enough to attract a French audience. The French press enthusiastically wrote about this guest appearance, and the quality of the performance made it possible for another group to visit the same year, from October 3 to 12, when 45 musicians and dancers arrived, whose performance was rated by the media as a Slavic Rhapsody. ${ }^{24}$ This performance was so notable that the Yugoslav artists extended their stay to perform again from October 18 to 28. Two years later, on November 23, 1954, singer Miroslav Čangalović performed a concert at the Paris Conservatory of Music. The appreciation of Čangalović can be seen from the fact that he was awarded best singer of the season (for his role of Mephistopheles, 1959) by the International Jury of Critics at the Theater of Nations Festival in Paris. ${ }^{25}$

These performances had a significant resonance with the public and contributed to the promotion of Yugoslavia. In addition to the guest performances of prominent artists in Paris, which were used at this stage of Yugoslavia's cultural and diplomatic activities in France, other manifestations in other parts of the country also took place, featuring folk groups and choirs, where the target group was younger. For example, Poitiers was, and still is today, a particularly significant place for education, and therefore a very convenient place to promote a country that is less well-known in the world. ${ }^{26}$ The Zagreb-based Jože Vlahović folklore troupe performed there on April 6, 1954, as guests at the event Compagnons de la Claire Fontaine, dedicated to the traditional music, song and dance. The group performed for an audience composed mainly of foreign students. In February 1955, young Slovenian violinist Igor Ozim, who had a promising international career in front of him, held two concerts at the Salle Gaveau and the Cité internationale universitaire in Paris. The Salle Gaveau, which was also the headquarters of the

\footnotetext{
${ }^{24}$ Ibid., 96-97; "Novi veliki uspeh Ansambla narodnih igara Srbije [The novel great success of the Ensemble of Folk Dances of Serbia]," Politika (July 17, 1952): 4; "Uspelo gostovanje Ansambla narodnih igara Srbije u Engleskoj, Holandiji i Francuskoj [The successful guest performance of the Ensemble of Folk Dances of Serbia in England, the Netherlands and France]," Politika (July 17, 1952): 4 .

${ }^{25}$ Mirjana Odavić, Miroslav Čangalović (1921-1999) (Belgrade: Muzej pozorišne umetnosti, 2002). ${ }^{26}$ Ekmečić, Poslednjih sto godina, 78.
} 
French piano manufacturer Gaveau (one of the three largest piano manufacturers in France), was (and still is) a prestigious place for great pianists. The second venue-the Cite internationale universitaire-was a center of student life for the future French elite, but also for students from other countries, who were able to take with them the image of Yugoslavia to their own countries. Yugoslav artists also took part in musical competitions in France, such as the VI Besançon Music Festival (Festival de musique de Besançon Franche-Comté). In a competition of 40 orchestra conductors, Igor Đarov and Krešimir Šipuš from Zagreb won first place. ${ }^{27}$ Yugoslav diplomacy in this time sought to be represented in France by famous musicians from all Yugoslav republics. All the examples above testify that the cultural diplomacy of Yugoslavia in France sought to extend its influence further than only the French. As a hub of ideas and people of different nationalities, France was a great place for Yugoslav diplomacy in context of the global promotion of the new Yugoslavia. This was also in line with the opening of Yugoslavia to the West.

It can be said that the cultural diplomacy of Yugoslavia, in which music became very important, also prepared the political atmosphere for Titos first official visit to France. In January 1955, French President René Coty invited the Yugoslav leader to France, but the official visit was delayed until 1956. At that time, the Yugoslav embassy in Paris was led by Aleš Bebler, a communist and Spanish Civil War veteran who studied law in Paris, where he occasionally lived in exile between 1931 and 1939. 28 The same year, the Belgrade Opera performed again at the Champs Élysées Theater in mid-April, starring Miroslav Čangalović, Dušan Popović, Valerija Heybal and Melanija Bugarinović in the lead roles. ${ }^{29}$ At the same time, the French and Yugoslav press wrote about the expectations from the upcoming visit, about Yugoslavia, Tito, the common history and fight against the enemy in the two world wars. Guy Mollet, French Prime Minister and socialist, who had visited Yugoslavia in 1952, told the Sarajevo-based paper Oslobodenje (Liberation): "I will be happy to greet the President of Yugoslavia in Paris." On the other hand, Josip Broz Tito told Le Monde reporters: "I'm looking forward to visiting France, where I haven't been since 1939." 30 The second interview with Tito in the prestigious newspaper was published on May 5, 1956. Tito's visit (May 7-12) was accompanied by increased cultural activities of Yugoslavia in France, which continued in the subsequent

\footnotetext{
27 Ibid.

28 "Aleš Bebler," in Petar Kačavenda, Dušan Živković, Narodni heroji Jugoslavije, Vol. 1 (Belgrade: Narodna knjiga, 1982), 66.

${ }^{29}$ Ekmečić, Poslednjih sto godina, 102.

30 "Poseta pretsednika Tita Francuskoj biće koristan doprinos jačanju međunarodne saradnje [President Tito's visit to France will contribute to the strenghtening of international cooperation]," Politika (May 5, 1956): 1; "Prijateljski Pariz svečano dočekao pretsednika Tita [Friendly Paris solemnly welcomes President Tito]," Politika (May 8, 1956):1.
} 
period, only at lower intensity. ${ }^{31}$ At the end of May 1956, the Ensemble of Folk Dances and Songs of the Peoples of Yugoslavia performed at the Huyghens Hall in the $14^{\text {th }}$ district in Paris, which was a well-known exhibition space for Parisian painters in the interwar period. Twice, in 1956 and 1957, Paris hosted top soloists from Zagreb, sisters Olga and Marija Mihajlović, who held a recital at the École Normale de Musique as part of their second visit. ${ }^{32}$ At the end of March 1957, the Theater de Nation hosted the Belgrade Opera again, which raised great interest and respect among the French audience. As a result, Oskar Danon, conductor of the Belgrade Opera, was invited to conduct the Philharmonic Orchestra in Nice in 1958 as part of the Summer Music Festival. ${ }^{33}$

While the famous French singer Josephine Becker performed in Belgrade, the ballet ensemble of the Belgrade National Theater performed at the Théatre de l'Étoile. Cultural exchanges and visits by musicians were well developed at the time when Radivoje Uvalić, ${ }^{34}$ another former law student in France and Spanish Civil War veteran, was appointed as the next Yugoslav Ambassador to France in 1957. While the new Yugoslav state started its cultural diplomacy in the first years after 1945 with folklore, folk groups and choirs, classical music took center stage in the 1950s, and famous Yugoslav musicians "spoke the language of diplomacy." The place of music within the framework of Yugoslavia's cultural diplomacy was much more clearly defined and it was used much more intensively than only ten years earlier, when only folk groups and choirs built the image of Yugoslavia. Classical music was on the diplomatic throne, and world-famous musicians, such as Čangalović and Ozim, were used to promote the culture of the country that broke free from the influence of the USSR and was getting closer to the West. Yugoslav cultural diplomacy was not limited to Paris and also penetrated into other parts of France. Poitiers hosted a number of Yugoslav musicians and artists, and one such example was the guest performance of the Slovenian Quartet at the end of 1960. We should note, however, that Yugoslav cultural diplomacy relied heavily on the French Alliance at that time, where we can see long cooperation extending back to the time of the Kingdom of Serbia and the Kingdom of Yugoslavia.

\footnotetext{
31 "Le Maréchal Tito: nos conversations avec les représentants de la France seront heureux et utiles [Marshal Tito: our talks with the French representatives were cordial and useful]," Le Monde (May 8, 1956): https://www.lemonde.fr/archives/article/1956/05/08/le-marechal-tito-nos-conversationsavec-les-representants-de-la-france-seront-heureux-et-utiles_2254503_1819218.html; Momčilo Stefanović, Svet $i$ Tito [The world and Tito] (Zagreb, Novi Sad: Globus, Matica Srpska, 1988). See also Marshal Tito On State Visit To Paris, https://www.youtube.com/watch?v=uZQAc6zwGtQ (accessed on April 20, 2020).

32 Ekmečić, Poslednjih sto godina, 103.

33 Ibid.

${ }^{34}$ Venceslav Glišić, “Radivoje Uvalić,” in Enciklopedija Jugoslavije, Vol. 8 (Zagreb: JLZ, 1971), 448.
} 
Silenced tones:

Disruption of diplomatic relations and attempts

at cultural diplomacy in the 1960s

Numerous performances by Yugoslav musicians and artists in France created an atmosphere of improving relations between France and Yugoslavia, but 1960 came with a turnaround. After President Coty, who was even less active than his predecessor in trying to influence policy, France and Yugoslavia began growing apart, and cultural diplomacy, even music, could do little to help. Coty's presidency was troubled by the political instability of the Fourth Republic and the Algerian question. With the deepening of the crisis in 1958, Coty appealed to Charles de Gaulle, the "most illustrious of Frenchmen," to become the last Prime Minister of the Fourth Republic. Coty had threatened to resign if de Gaulle's appointment was not approved by the National Assembly. The period of the French Fifth Republic began with de Gaulle, which-in addition to major changes in France and particularly the war in Algeria-also influenced international politics. However, serious problems existed in the Franco-Yugoslav relations already before (the relations between de Gaulle and Tito, the political emigration of Serbs and Croats (the Ustashas) to France, the war in Algeria, decolonization, the Non-Aligned Movement, etc.). Charles de Gaulle, who grew up on monarchist beliefs and believed in the power of the law, considered the fate which Tito served general Mihailović to be unacceptable. ${ }^{35}$ Moreover, he believed the Yugoslav federation as such to be a highly fragile state structure.

Another shadow was cast on the Franco-Yugoslav (Serbian) relations by Tito when he received Algerian Prime Minister Ferhat Abbas in Belgrade, which was, of course, not a welcome move for Paris. ${ }^{36}$ However, it seems that French diplomacy wanted to maintain firm ties with Belgrade. For a new French Ambassador to Yugoslavia, France proposed the son of Franchet d'Espèrey, a famous general and commander of the Allied army that penetrated the Southern Front and liberated Serbia in the Great War. But his credentials were rejected by the Yugoslav side because of his strong ties with Serbian political émigrés in Paris. In response, de Gaulle organized an official reception for former Yugoslav Queen Maria Karađorđević, Prince Regent Paul Karađorđević, Bogoljub Jevtić, former

\footnotetext{
${ }^{35}$ Jean-Christophe Buisson, Héros trahi par les Alliés, le général Mihailović (1893-1946) [Heroes Betrayed by the Allies, General Mihailović (1893-1946)] (Paris: Librairie Académique Perrin, 1999). ${ }^{36}$ Dragan Bogetić, "Podrška Jugoslavije borbi alžirskog naroda za nezavisnost u završnoj fazi alžirskog rata 1958-1962 [Yugoslav support in the battle of Algerians for independence in the final phase of the Algerian War 1958-1962]," Istorija 20. veka 3 (2012): 147-162; Vojislav Pavlović, "La guerre d'Algérie et la quête d'une nouvelle politique étrangère de la Yougoslavie de Tito [The Algerian War and the adoption of a new foreign policy of Tito's Yugoslavia]," in La guerre d'Algérie et le monde communiste, edited by Hervé Bismuth, Fritz Taubert (Paris: EUD Histories, 2014), 119-138.
} 
President of the Royal Government and Minister of Foreign Affairs, recipient of the Grand Cross of the Legion of Honor, Dragiša Cvetković, former Prime Minister of the Kingdom of Yugoslavia, and Prince Michael Petrović-Njegoš, pretender to the throne of Montenegro. ${ }^{37}$ After Yugoslavia recognized the Algerian government in 1961, the Yugoslav ambassador left Paris upon request of the French government. The local press wrote that Tito's regime assisted the opposing side in the war by sending weapons. They even mentioned a donation of $\$ 55$ million for the Algerian Liberation Front. After that, cultural exchanges and guest appearances by Yugoslav musicians and artists became increasingly rare. Music within the framework of cultural diplomacy fell silent.

The cultural diplomacy of Yugoslavia in France was revived with the fall of de Gaulle from power. A new wave of representation of Yugoslavia began gradually from 1968, but without a clear plan and guidelines, and mostly related to the activities of the diaspora. An attempt was made by establishing a club (Club of the Yugoslav Embassy), ${ }^{38}$ but the results could not be seen immediately, especially after a bomb attack on the club in 1968 organized by Yugoslav political emigrants. ${ }^{39}$ Therefore, Yugoslavia acted through informal channels. One of them was a bookstore called Yougo-France, owned by Fadil Ekmečić, who collected numerous testimonies on Yugoslav citizens in France, as well as about relations between France and Yugoslavia after 1945. In April 1968, Yougo-France organized a fair at the Porte de Clignancourt, selling Yugoslav books and products, particularly popular music records. Also, a Grand Yugoslav Week (Grand Semaine Yougoslave) was held at the Palaiseau House of Youth and Culture (Maison des jeunes et de la culture de Palaiseau) in May 1968. The event was organized by the bookstore, but Yugoslav Ambassador Ivan Vejvoda ${ }^{40}$ was present at the opening ceremony.

The Grand Yugoslav Week included painting exhibitions by Petar Lubarda, Milo Milunović, Ivan Generalić, Marko Čelebonović and others, as well as a folklore and entertainment program, in which popular Yugoslav music pop star Tereza Kesovija appeared. This period was followed by a resurgence of concerts by singers of popular Yugoslav and folk music, which were partly supported by the Yugoslav Embassy. However, The purpose of these manifestations was not cultural diplomacy,

\footnotetext{
37 "Tito et de Gaulle [Tito and de Gaulle]," Le Monde (May 26, 1980): https://www.lemonde.fr/ archives/article/1980/05/26/tito-et-de-gaulle_2822508_1819218.html; Ekmečić, Poslednjih sto godina, 125.

38 DAMSPRS, 1965, France, Note: Le Club de l'Ambassade de Yougoslavie.

39 "France: Paris Bomb Explosion In Basement Of Yugoslav Embassy," British Pathé (February 18, 1968): https://www.britishpathe.com/video/VLVACSEKFBGP69GI3ZQ84KCVSLGAGFRANCE-PARIS-BOMB-EXPLOSION-IN-BASEMENT-OF-YUGOSLAV-EMBASSY/query/ Embassy.

40 Aleksandar Životić, "Ivan Ivo Vejvoda," in Srpska enciklopedija, Vol. 2 (Belgrade, Novi Sad: SANU, Matica srpska, 2013), 180.
} 
and they were addressing more the Yugoslav diaspora. One of them was a concert by Esma Redžepova and the Stevo Teodosievski Ensemble at the Syndicat du livre. Apart from the bookstore Yougo-France, the second organizer of Yugoslav concerts in France was the Brotherhood and Unity Association of Yugoslav Emigrants. The Oro folk group performed at the celebration of Republic Day in 1970, and this event was organized by the Brotherhood and Unity Association, not the Yugoslav Embassy. In addition, we should mention the work of the folk dance group called Folliane (from Issy-les-Moulineaux), consisting of young French people who performed a Yugoslav dance program. ${ }^{41}$ The founder was choreographer Viviene Chloquet. In addition to folklore as a means of cultural communication, a new wave of twinning French and Yugoslav towns was also attempted, encouraging alliances and lasting friendship, and concerts were held within related festivities. Manifestations called "Meetings with singers" were also organized in cooperation with Yugoslav record labels (RTV, Diskoton, Jugoton). At that time, Yugoslav performers in France included successful pop musicians Korni Group and Arsen Dedić, but also folk singers Safet Isović, Predrag Živković Tozovac, Gvozden Radičević and Andrija Ojdanić performed in Paris, but mostly only for the diaspora. In February 1971, Inex - France was established as an exclusive importer of Yugoslav records and a concert organizer for Yugoslavs. ${ }^{42}$ The diaspora, especially the bookstore Yougo-France and the Brotherhood and Unity Association, took over most of the cultural promotion of Yugoslavia, and thus the program shifted from ballet, opera and classical music in the direction of popular Yugoslav singers. Such events were organized in order to animate the diaspora for Yugoslavia, as well as to achieve unity in the diaspora and its attachment to the new state, especially with a wave of economic migration in those years.

\section{Conclusion}

After 1945, new Yugoslavia and its communist rule emerged on the international stage, seeking to present itself to the entire Western world. This implied a break with the legacy of the French-Serbian relations, which also affected the content of the cultural and diplomatic package of Yugoslavia in France. Contemporaries recognized that "in the post-WWII period official politics destroyed the bridges of previous friendly French-Serbian cooperation." ${ }^{33}$ Cultural diplomacy tried to smooth the open issues in diplomatic relations between France and Yugoslavia

\footnotetext{
${ }^{41}$ Ekmečić, Poslednjih sto godina, 132.

42 Journal-export: specijalni broj posvećen francusko-jugoslovenskim odnosima (1956 -1984) (Belgrade, 1983).

${ }^{43}$ Dragan Nedeljeković, "Srpska dijaspora u Francuskoj posle Drugog svetskog rata [The Serbian diaspora in France after the World War II]," in Danica, srpski narodni ilustrovani kalendar za 1994 godinu (Belgrade: Vukova zadužbina, 1994), 278-279.
} 
(poor relations between de Gaulle and Tito, Yugoslav political emigrants in France, cooperation between the Communist Parties, Tito's support in the Algerian War). Music in the framework of the cultural diplomacy of Yugoslavia in France from 1945 to 1970 passed a long path, from an important aid in representing the new state to a forgotten tool of diplomatic activity. Official activities lacked a systematic approach despite initial sporadic successes, firstly with choral performances in 1948, as well as the great success of Yugoslav classical musicians in 1952, and again in 1956, at the time of Tito's official visit. Already before the interruption of diplomatic relations between France and Yugoslavia in 1960, problems had arisen in coordination of cultural-diplomacy activities between the Embassy and Yugoslav associations in France, along with enormous insecurity and distrust in Franco-Yugoslav cooperation (between the Yugoslav and French communists, as well as between the Embassy and the Ministry of Foreign Affairs). All of this also applied to the use of music for soft power purposes.

De Gaulle's departure from power and the arrival of Georges Pompidou in 1969 created the conditions for the thawing of relations between the two states. Cultural diplomacy once again served as an important link in the normalization of relations. ${ }^{44}$ The lack of sufficient activity in France in this field of public diplomacy is also evident from the occasion of Tito's next official visit to France. Although, of course, international circumstances had changed, it was noticed that Tito's visit to Paris, during which he met French President Georges Pompidou (October 23, 1970) gained less attention in the public than the previous one. ${ }^{45}$ In the 1960s, the tones of music became forgotten in the pursuit of Yugoslav diplomatic goals, and instead Yugoslav popular music was used to keep the diaspora together. Classical music and performers with a high reputation around the world were present within the framework of cultural exchange, but insufficiently visible for the purpose of Yugoslav diplomacy toward France. But the cultural diplomacy of Yugoslavia in France also went through certain changes. These changes are reflected in the establishment of the Culture and Information Center of Yugoslavia in 1974. ${ }^{46}$ The

\footnotetext{
${ }^{44}$ Arnold Suppan, "La politique culturelle yougoslave durent d'ère Tito [The cultural politics of Yugoslavia in Tito's era]," in Culture et Guerre froide, edited by Jean-François Sirinelli, Georges Henri Soutou. (Paris: Presses Paris Sorbonne, 2005), 183-205.

45 "Tito u Parizu [Tito in Paris]," Politika (October 24, 1970): 1; Gilles Troude, "La Yougoslavie titiste vue par les diplomates français (1955-1974) [Tito's Yugoslavia from the perspective of French diplomats (1955-1974)]," Balcanica XL (2009): 167-181.

${ }^{46}$ Kolaković, "Kultura i diplomatija: Francuska i Srbija," 101-122; Ljiljana Rogač Mijatović, Kulturna diplomatija i identitet Srbije [Cultural Diplomacy and the Identity of Serbia] (Belgrade: FDU, CLIO, 2014), 203-205; Branislav Pantović, Nina Aksić, "Instrumentalizacija institucija kulture u međunarodnom ambijentu na primeru Kulturnog centra Srbije (Pariz) i turskog kulturnog centra Junus Emre (Novi Pazar) [Instrumentalization of cultural institutions in international affairs on the example of the Serbian Culture Center in Paris and the Turkish culture center Junnus Emre (Novi Pazar)]," Zbornik Fakulteta dramskih umetnosti 31 (2017): 163-179.
} 
new course of using soft power marked by the Culture and Information Center of Yugoslavia in Paris, however, never fully justified the high expectations, but this is already a different topic. Based on the analysis of the cultural diplomacy of post-war Yugoslavia in France, we can state that music was not used sufficiently as a tool of diplomatic activity. More efforts were made to make an impact with lectures, exhibitions and translations, but none of these, apart from fine arts, achieved a high reach. In Yugoslavia's cultural diplomacy, music was underutilized, although it can speak a universal language in diplomatic activities as well as fine arts. 


\section{Primary sources:}

Archival sources

Archives of the Ministry of Foreign Affairs (AMAE) (Paris): Z Europe Yugoslavia

Diplomatic Archives of the Ministry of Foreign Affairs of the Republic of Serbia (DAMSPRS) (Belgrade): France
Press and periodicals

Journal-export: specijalni broj posvećen francusko-jugoslovenskim odnosima (1956-1984) (Belgrade, 1983)

Le Monde, Paris, 1944-

Politika, Belgrade, 1904-

\section{Internet sources:}

"France: Paris Bomb Explosion In Basement Of Yugoslav Embassy." British Pathé (February 18, 1968): https://www.britishpathe.com/video/VLVACSEKFBGP69GI3ZQ84KCVSLGAGFRANCE-PARIS-BOMB-EXPLOSION-IN-BASEMENT-OF-YUGOSLAV-EMBASSY/ query/Embassy.

Marshal Tito On State Visit To Paris, https://www.youtube.com/watch?v=uZQAc6zwGtQ (accessed on April 20, 2020).

\section{References:}

"Ambasador Srđa Prica srdačno dočekan u Lionu." Politika (June 11, 1952): 5. [Orig. in Serbian Cyrillic]

Assouline, Pierre. Lutetia. Paris: Gallimard, 2005.

Bataković, Dušan T. Une alliance atypique Les relations franco-serbes 1878-1940. Belgrade: Balkanološki institut SANU, 2010.

Bataković, Dušan T. "Francuski uticaji u Srbiji 1835-1914. Četiri generacije Parizlija.” Zbornik Matice srpske za istoriju 57 (1997): 73-95. [Orig. in Serbian Cyrillic]

Bogetić, Dragan. "Saradnja Jugoslavije i zapada u vreme sukoba sa Kominformom (19521955)." In Velike sile i male države u Hladnom ratu: slučaj Jugoslavije, edited by Ljubodrag Dimić, 43-62. Belgrade, London: Filozofski fakultet Beograd, Katedra za istoriju Jugoslavije, Arhiv Srbije i Crne Gore, Institut za noviju istoriju Srbije, Centar za istraživanja hladnog rata LST, 2005. [Orig. in Serbian Cyrillic]
Bogetić, Dragan. "Podrška Jugoslovije borbi alžirskog naroda za nezavisnost u završnoj fazi alžirskog rata 1958-1962." Istorija 20. veka 3 (2012): 147-162.

Buisson, Jean-Christophe. Héros trahi par les Alliés, le général Mihailović (1893-1946). Paris: Librairie Académique Perrin, 1999.

Dedijer, Vladimir. The battle Stalin lost: memoirs of Yugoslavia 1948-1953. New York: Grosset \& Dunlap, 1972.

Ekmečić, Fadil. Poslednjih sto godina Jugoslovena u Francuskoj / La Presence Yougoslave en France depuis 100 ans. Paris: Yougo-France, 1981.

Enciklopedija Jugoslavije. Vol. 6. Zagreb: Jugoslovenski leksikografski zavod, 1965.

Glišić, Venceslav. "Radivoje Uvalić." In Enciklopedija Jugoslavije, Vol. 8, 448. Zagreb: JLZ, 1971.

Kačavenda, Petar, Živković, Dušan. Narodni heroji Jugoslavije, Vol. 1. Belgrade: Narodna knjiga, 1982. 
Kolaković, Aleksandra, "Kultura i diplomatija: Francuska i Srbija." In Kulture u dijalogu - Cultures in Dialogue, Cultural Diplomacy and Libraries, Vol. 3, edited by Aleksandra Vraneš, Ljiljana Marković, 101-122. Belgrade: Filološki fakultet, 2013. [Orig. in Serbian Cyrillic]

Kolaković, Aleksandra. U službi otadžbine: saradnja francuskih i srpskih intelektualaca. Belgrade: Institut za političke studije, 2016. [Orig. in Serbian Cyrillic]

Kolaković, Aleksandra. "War and Propaganda in 1915: French Intellectuals and Actualization of Serbian Issues." In The Great War in 1915, edited by Dalibor Denda, Christian Ortner, 330-352. Belgrade, Vienna: Institut za strategijska istraživanja, 2017.

Kolaković, Aleksandra. "Présentation de la nouvelle Yougoslavie en France de 1945 à 1973. Diplomatie et culture." In La France et la Serbe: Les défis de l'amitié éternelle, edited by Aleksandra Kolaković, Sacha Markovic. Belgrade: Institut za političke studije, 2020, forthcoming.

Kolaković, Aleksandra. "Serbian Press in France during the 20 $0^{\text {th }}$ Century: Among the Cultural Diplomacy and the Information on the Diaspora." Les Cahiers balkaniques 47 (2020): 139-154.

Le cas Yougoslave: intéresse l'opinion publique. Toulouse: Association des jeunes des brigades en Yougoslavie, 1948.

"Le Maréchal Tito: nos conversations avec les représentants de la France seront heureux et utiles." Le Monde (May 8, 1956): https://www.lemonde.fr/archives/ article/1956/05/08/le-marechal-titonos-conversations-avec-les-representants-de-la-france-seront-heureux-etutiles_2254503_1819218.html.
Lemesle, Hervé. "Les volontaires yougoslaves en Espagne républicaine: des sources pour une étude prosopographique: des sources pour une étude prosopographique." Matériaux pour l'histoire de notre temps 123/124 (2017): 50-58.

Milošević, Miladin. "Dolazak u Pariz prvog ambasadora Nove Jugoslavije." In Srpsko-francuski odnosi 1904-2004, edited by Mihailo Pavlović, Jelena Novaković, 123-131. Belgrade: Društvo za kulturnu saradnju Francuska Srbija, Arhiv Srbije, 2005. [Orig. in Serbian Cyrillic]

Nedeljeković, Dragan. "Srpska dijaspora u Francuskoj posle Drugog svetskog rata.” In Danica, srpski narodni ilustrovani kalendar za 1994 godinu, 278-279. Belgrade: Vukova zadužbina, 1994. [Orig. in Serbian Cyrillic]

Odavić, Mirjana. Miroslav Čangalović (1921-1999). Belgrade: Muzej pozorišne umetnosti, 2002.

Pantović, Branislav, Aksić, Nina. "Instrumentalizacija institucija kulture u međunarodnom ambijentu na primeru Kulturnog centra Srbije (Pariz) i turskog kulturnog centra Junus Emre (Novi Pazar)." Zbornik Fakulteta dramskih umetnosti 31 (2017): 163-179.

Pavlović, Mihailo, Novaković, Jelena. Srpskofrancuski odnosi 1904-2004. Belgrade: Arhiv Srbije, 2004. [Orig. in Serbian Cyrillic]

Pavlović, Vojislav. "La guerre d’Algérie et la quête d'une nouvelle politique étrangère de la Yougoslavie de Tito." In La guerre d'Algérie et le monde communiste, edited by Hervé Bismuth, Fritz Taubert, 119-138. Paris: EUD Histories, 2014.

Pešić, Savo. "Komunistička partija Jugoslavije i španski građanski rat." Vojnoistorijski glasnik 2 (1986): 261-276. [Orig. in Serbian Cyrillic] 
"Poseta pretsednika Tita Francuskoj biće koristan doprinos jačanju međunarodne saradnje." Politika (May 5, 1956): 1. [Orig. in Serbian Cyrillic]

"Prijateljski Pariz svečano dočekao pretsednika Tita." Politika (May 8, 1956): 1. [Orig. in Serbian Cyrillic]

Ristić, Marko. Književna politika: članci i pamfleti. Belgrade: Prosveta, 1952.

Ristić, Marko. Politička književnost (za ovu Jugoslaviju) 1944-1958. Sarajevo: Oslobođenje, 1977.

Ristić, Marko. Diplomatski spisi. Belgrade: Prosveta, 1996.

Rogač Mijatović, Ljiljana, Kulturna diplomatija $i$ identitet Srbije. Belgrade: FDU, CLIO, 2014. [Orig. in Serbian Cyrillic]

Selinić, Slobodan. "Ambasador nekomunista i partijska diplomatija. Marko Ristić u Parizu 1945-1951." Tokovi istorije 2 (2012): 144-145. [Orig. in Serbian Cyrillic]

Selinić, Slobodan. Partija i diplomatija u Jugoslaviji 1945-1952. Belgrade: Institut za noviju istoriju Srbije, 2013. [Orig. in Serbian Cyrillic]

Sretenović, Stanislav. Francuska i Kraljevina Srba Hrvata i Slovenaca 1919-1929. Belgrade: Institut za savremenu istoriju, 2009.

Stefanović, Momčilo. Svet i Tito. Zagreb, Novi Sad: Globus, Matica Srpska, 1988.
Suppan, Arnold, "La politique culturelle yougoslave durent dère Tito." In Culture et Guerre froide, edited by Jean-François Sirinelli, Georges Henri Soutou, 183-205. Paris: Presses Paris Sorbonne, 2005.

Šobe, Fransoa, Marten, Loren. Medunarodni kulturni odnosi. Belgrade: Clio, 2014.

Štrbac, Čedomir. Jugoslavija i odnosi između socijalističkih zemalja: sukob KPJ $i$ Informbiroa. Belgrade: Prosveta, 1984.

"Tito et de Gaulle." Le Monde (May 26, 1980): https://www.lemonde.fr/ archives/article/1980/05/26/tito-et-degaulle_2822508_1819218.html.

"Tito u Parizu." Politika (October 24, 1970):

1. [Orig. in Serbian Cyrillic]

Terzić, Slavenko (Ed.). Jugoslovensko-francuski odnosi: povodom 150 godina od otvaranja prvog francuskog konzulata u Srbiji. Belgrade: Istorijski institut, 1990. [Orig. in Serbian Cyrillic]

Troude, Gilles. "La Yougoslavie titiste vue par les diplomates français (1955-1974)." Balcanica XL (2009): 167-181.

Životić, Aleksandar, "Ivan Ivo Vejvoda." In Srpska enciklopedija, Vol. 2, 180. Belgrade, Novi Sad: SANU, Matica srpska, 2013. [Orig. in Serbian Cyrillic] 



\title{
Sounding the turn to the West: Music and diplomacy of Yugoslavia after the split with the USSR and the countries of "people's democracy" (1949-1952)
}

\author{
Biljana Milanović
}

My grasp of the research area of music and diplomacy is grounded on the experience that I gained through the realization of a project investigating the Belgrade Choral Society's concert tours abroad at the turn of the $20^{\text {th }}$ century. ${ }^{1}$ There, I explored how music was incorporated into the diplomatic strategies that the Kingdom of Serbia practiced in its cross-border relationships with empires, states, cities and ethnic communities of the Central, Eastern, South-Eastern and Ottoman Europe of the time. Focusing on a new topic in this article, my approach to music in diplomatic interactions remains the same line. It is placed in the context of cultural diplomacy and poses questions about the involvement of music in policies and practices of cross-border networking, exchange, representation, negotiation and mediation, while encompassing different state officials and non-officials, groups, institutions and organizations, as well as both formal and informal, elitist and non-elitist events and activities. Such an approach shares its interests with a spectrum of contemporary studies that open the space for investigating diplomacy as a social and cultural practice. ${ }^{2}$

\footnotetext{
1 See Biljana Milanović, "Musical Representation of Mokranjac and the Belgrade Choral Society as a Form of Cultural Diplomacy," in Stevan Stojanović Mokranjac (1856-1914): The Belgrade Choral Society Foreign Concert Tours, edited by Biljana Milanović (Belgrade: Institute of Musicology SASA and Serbian Musicological Society, 2014), 11-42.

2 See, for example, Music and Diplomacy from the Early Modern Era to the Present, edited by Rebekah Ahrendt, Mark Ferraguto, Damien Mahiet (New York: Palgrave Macmillan, 2014); Houssine Alloul, Michael Auwers, "What is (New) Diplomatic History?," Journal of Belgian History 48/4 (2018): 112-122; Cécile Prévost-Thomas, Frédéric Ramel, "Introduction: Understanding Musical Diplomacies-Movements on the 'Scenes'," in International Relations, Music and Diplomacy, Sounds and Voices on the International Stage, edited by Frédéric Ramel, Cécile Prévost-Thomas (London: Palgrave Macmillan, 2018), 1-19; Giles Scott-Smith, Kenneth Weisbrode, "Editorial," Diplomatica: A Journal of Diplomacy and Society 1/1 (2019): 1-4.
} 
The research of music and diplomacy in socialist Yugoslavia $(1945-1991)^{3}$ is an extensive, complex and interdisciplinary task that musicologists have not dealt with so far. My work focuses on the period after the conflict with the Cominform (1948), when the Federal People's Republic of Yugoslavia (FPRY), faced with the problem of political and economic isolation and complete severance of relations with the Soviet Union and other countries of "people's democracies," made a strategic turn to the countries of parliamentary democracy. Music gained a significant role as a mediator in diplomatic efforts to renew broken ties with the West. Within the framework of the new international cooperation with a number of countries, various types of musical activities were conceived in a relatively short time and already realized in the period of 1950-1952.

In the text, I deal with the role of music in the realization of the new diplomatic policy of turning to the West. I am primarily dedicated to the contextualization of musical activities, not only with respect to the foreign, but also the internal policy of the FPRY, its cultural policy, as well as certain ideological and aesthetic views on music in Yugoslavia. ${ }^{4}$

\section{Visions for cultural (and musical) activities in the new diplomatic agenda}

In the regrouping of power after the WWII, Yugoslavia openly sided with ideological like-minded countries, supporting the Soviet Union in the conflict with the capitalist West. Yugoslavia also opted for the Soviet social and cultural model internally, and in the field of art, it accepted the doctrine of socialist realism. The conflict with the Cominform in 1948, the uncertainty of survival due to the severance of communication with the Eastern Bloc, the real danger of a Red Army intervention, and finally the decision to accept military and economic aid from Western countries and the United States, proved to be crucial preconditions for change in the long-term perspective. During the 1950s, Yugoslavia built its own

\footnotetext{
3 The official name of socialist Yugoslavia changed several times. With the Constitution of January 31, 1946, Democratic Federal Yugoslavia (DFY), which was created during the war (1943), ceased to exist, and the Federal People's Republic of Yugoslavia (FPRY) was established. With the Constitution of April 7, 1963, the name of the Federal People's Republic of Yugoslavia changed to the Socialist Federal Republic of Yugoslavia (SFRY).

4 I based my research on the study of archival material, supplemented by various secondary sources. The archive fonds of the FPRY Government's Council for Science and Culture [Komitet za nauku i kulturu vlade FNRJ], which was in charge of scientific and cultural relations with foreign countries at the federal level, served as the main analytical material (Archives of Yugoslavia /Arhiv Jugoslavije, AJ / The FPRY Government's Council for Science and Culture, 317-5-12). A two-volume collection of selected archival material related to the cultural policy of Yugoslavia until 1952 was also useful: Branka Doknić, Milić F. Petrović, Ivan Hofman (Eds.), Kulturna politika Jugoslavije 1945-1952. Zbornik dokumenata, Vols. 1-2 (Belgrade: Arhiv Jugoslavije, 2009).
} 
version of socialism, which at the same time represented new international positioning of the state. It was the only socialist country that was acceptable in the eyes of the West, and it gradually renewed its ties with the countries of the Eastern Bloc, but maintained a distance from favoring any of the two sides in the Cold War division, while focusing on the struggle of "small" nations for independence, peaceful resolution of crises, and strengthening the role of the United Nations. The country got closer to many countries of the so-called Third World, and became one of the main factors in the formation of the Non-Aligned Movement (1961). At the same time, the processes of reshaping politics, society and culture took place within the state itself through the rejection of Soviet models, weakening of dogmatism and party control, introduction of public property, decentralization and creating a model of self-government, as well as liberalization in art, moving away from the initial framework of socialist realism. ${ }^{5}$

The beginnings of the liberalization of cultural policy in the country itself were gradual and uneven. The paradigm of socialist realism in music was still dominant immediately after the break-up with the Eastern Bloc. Music production abounded in mass songs, cantatas and remakes of folk songs. The prevailing attitude was that new music should be "healthy," "objective," appropriate to the socialist rebirth of the country and accessible to the masses. It was supposed to resist "foreign influences" resolutely, as well as "modernist trends," "idealistic views," "formalism," "subjectivism," "bourgeois decadence" and "constructivism." 6 From the beginning of the fifties, compositional-stylistic and aesthetic elements of moderated modernism started to appear slowly, and although social realism remained in place for some time, it started fading gradually and disappeared by the end of the decade. ${ }^{7}$ There is no doubt that

5 On the abovementioned changes in Yugoslavia's foreign, domestic and cultural policy, see Ljubodrag Dimić, Agitprop kultura. Agitpropovska faza kulturne politike u Srbiji 1945-1952 [Agitprop Culture. The Agitprop Phase of Cultural Policy in Serbia 1945-1952] (Belgrade: Rad, 1988); Vladimir Petrović, Jugoslavija stupa na Bliski istok: stvaranje jugoslovenske bliskoistočne politike 1946-1956 [Yugoslavia Enters the Middle East: The Creation of the Yugoslav Middle East Policy 1946-1956] (Belgrade: Institut za savremenu istoriju, 2007); Slobodan Selinić (Ed.), Spolina politika Jugoslavije 1950-1961 [Foreign Policy of Yugoslavia 1950-1961] (Belgrade: Institut za noviju istoriju, 2008); Dragomir Bondžić, Misao bez pasoša: međunarodna saradnja Beogradskog univerziteta 1945-1960 [Thought Without a Passport: International Cooperation of the University of Belgrade 1945-1960] (Belgrade: Institut za savremenu istoriju, 2011); Vladimir L. Cvetković, Pogled iza gvozdene zavese. Jugoslovenska politika prema zemljama narodne demokratije u susedstvu 1953-1958. godina [A Look behind the Iron Curtain. Yugoslav Policy Toward the Countries of People's Democracy in the Neighborhood 1953-1958] (Belgrade: Institut za savremenu istoriju, 2013); Branka Doknić, Kulturna politika Jugoslavije 1946-1963 [Cultural Policy of Yugoslavia 1946-1963] (Belgrade: Službeni glasnik, 2013).

6 Melita Milin, Tradicionalno i novo u srpskoj muzici posle Drugog svetskog rata (1945-1965) [The Traditional and the New in Serbian Music after the WWII (1945-1965)] (Belgrade: Muzikološki institut SANU, 1998), 31-46.

7 On socrealism in music, see Milin, Tradicionalno i novo, 14-46. On the different standpoints on moderate/moderated modernism in Serbian music, see Melita Milin, "Etape modernizma u srpskoj 
the restoration of the severed ties with the West was one of the pivotal influences in abandoning the rigid dogmatic principles and modernizing musical life.

After 1949, the Ministry of Science and Culture of the FPRY ${ }^{8}$ started considering intensively how to place Yugoslav culture in the countries of Western and Northern Europe, as well as other continents. ${ }^{9}$ From the beginning, activities in various fields of culture, art and science were both considered and carried out, with the aim of creating a broad platform that would enable the self-representation of the state, international exchange of experiences and the application of new knowledge for the benefit of internal changes and improvement. ${ }^{10}$ The previous collaborative relations in culture, which primarily focused on the countries of "people's democracy," were viewed with self-criticism. Own mistakes were analyzed in parallel with examining the interest of foreign countries to familiarize themselves with Yugoslavia. It was pointed out that there had been no deliberate cultural and propaganda activities in the previous period, that the exchange of artists took place "mathematically," mostly "based on reciprocity," which often did not leave room for choosing appropriate artists and representative cultural content that would best represent the country. ${ }^{11}$

The first elaborations on the types of cultural activity in the West were made under the pressure of the blockade and strong negative campaign of the Cominform, which was aimed at destroying Yugoslavia's reputation in all areas. They were based on the need to emphasize the distancing from the Soviet experience, as

muzici [Stages of modernism in Serbian music]," Muzikologija 6 (2006): 93-116; Ivana Medić, “The Ideology of Moderated Modernism in Serbian Music and Musicology," Muzikologija 7 (2007): 279-294; Vesna Mikić, “Aspects of (Moderate) Modernism," in Rethinking Musical Modernism, edited by Dejan Despić, Melita Milin (Belgrade: Serbian Academy of Sciences and Arts, Institute of Musicology SASA, 2008), 187-193.

8 The Ministry of Science and Culture of the FPRY, which included the Department for International Scientific and Cultural Links, existed until May 31, 1950. Its tasks were transferred to the Department for International Cultural Links of the already mentioned FPRY Government's Council for Science and Culture, which was operational form May 24, 1950, until January 15, 1953.

9 See AJ, 317-86-120, General materials on foreign relations. On forms of culture and science propaganda abroad. I. Cultural relations with foreign countries. II Scientific relations with foreign countries, [1949], Belgrade; Work plan of the Department for International Scientific and Cultural Links for 1950, s. a., Belgrade; A note on experiences in the field of our cultural propaganda abroad (our shortcomings), January 10, 1950, Belgrade.

10 The work within the cultural sector comprised of different activities in the fields of literature, fine arts, art music, stage arts and folk dance ensembles, including arts education practices and the field of media exchange and propaganda (the press, radio shows, records, film). The sector of scientific relations with foreign countries shared certain activities with the Academic Council of the FPRY, and included the exchange of scientific literature, exchange of scientists, specializations, scholarships and student exchanges, as well as Slavic seminars and institutes.

${ }^{11}$ AJ, 317-86-120, On forms of culture and science propaganda abroad. Direct insight into certain aspects of cultural, educational and scientific exchange of Yugoslavia with foreign countries in the period up to 1948 can be gained on the basis of archival documents published in Doknić, Petrović, Hofman, Kulturna politika Jugoslavije, Vol. 2, 233-302. 
well as stress the country's own anti-fascist legitimacy and consistency with the original postulates of Marxism and Leninism. The victorious model of direct war experience was also projected in the field of culture and exchange with the world. It was emphasized that "we should actively participate in the general ideological struggle on the cultural front," that "in that struggle, Yugoslavia occupies the same place and role as it had in the general revolutionary struggle," and that "this part of our country's international contribution [...] has not been in our mind until recently when we were closely tied to the countries of people's democracies and withdrew from the European and non-European fronts of struggle." 12

On the same basis, the tasks of scientific and cultural ties with foreign countries were formulated, which in this early phase reflected the increased caution and distrust toward the international community, but also clearly pointed to the policy of disagreement with the bloc division. While planning the activities for 1950, the following three general tasks were highlighted:

1. Inform foreign countries about events related to the cultural and scientific development in the Federal People's Republic of Yugoslavia, and thus spread the truth about the construction of socialism in it, because socialist upgrading, which foreigners will get to know about through such activities, is a result of the socialist basis;

2. Such efforts require initiative and consistent participation at the front of the ideological struggle, directing activity against reactionary tendencies of capitalist countries, as well as against non-Marxist, neo-pragmatist positions taken by the hegemony of the USSR and countries of people's democracies in the field of culture and science;

3. Acquaint our country with the development of science and culture abroad and advanced ideas reflected through such development.

Such activities will result in breaking the isolation in the scientific and cultural field that the leaders of the USSR and the countries of people's democracies intend to impose, and will contribute to a more comprehensive development of our science and culture on the one hand, and spreading the truth about our country on the other. ${ }^{13}$

The mentioned distrust, but also the strengthened control were evident in these early projections of international cultural and scientific cooperation. For example, a visit of Yugoslav artists abroad was viewed with a dose of suspicion: "The basic question that always arises in connection with these visits is the possibility for

\footnotetext{
$12 \mathrm{AJ}, 317-86-120$, On forms of culture and science propaganda abroad.

13 AJ, 317-86-120, Work plan of the Department for International Scientific and Cultural Links for 1950 .
} 
artists to stay abroad. It is the greatest concern. This fear has prevailed so far [...]." 14 It was common to form lists of artists who, in addition to highly professional criteria, also passed the ideological assessment, but even such a typically agitprop control practice could not be a guarantee against the possibility of undesired emigration. ${ }^{15}$

On the other hand, however, international relations in culture were outlined as one of the priorities of the new course of Yugoslavia from its outset, so it was necessary to act effectively in the direction of organizing international cooperation and better self-representation abroad. This also meant a very rapid weakening of rigid dogmatic controls and the emergence of certain aspects of liberalization and decentralization in the implementation of the ideas of new cultural diplomacy. Thus, republic-level ministries, professional art institutions, specific cultural and art associations, as well as individuals were involved in the planning and realization of international cultural cooperation. Foreign cooperation and visits became possible even without the federal ministry, i.e. the Council for Science and Culture, playing the role of arbiter. At the same time, foreign diplomatic representatives in the country and Yugoslav representatives abroad were particularly active in bolstering cultural cooperation, along with various organizations such as the British Council, the Yugoslav-British Friendship Society, the Austrian-Yugoslav Cultural Relations Society, the Yugoslav Information Center in New York, as well as representatives and managers of foreign festivals, art institutions and independent foreign impresarios. The spreading of this network, which grew denser over time, implied at least two aspects that influenced the gradual establishment of a more relaxed attitude toward creativity and artists. The first referred to the respect for a professional opinion, talent and quality that was necessary to acquire a new position in the eyes of the Western, capitalist world. The second pointed to the adjustment to the ways this world functioned, that is, the adoption of specific business models in the organization, presentation and realization of the planned propaganda tasks.

Already in the earliest projections of such a diplomatic penetration into the West, music was assessed as the branch of art that offered the most comprehensive propaganda possibilities. It seems that art music could not compete only with the promotion of folk dance ensembles, which most easily penetrated the foreign musical scene and quickly became a commercial product of Yugoslav culture. ${ }^{16}$ Deliberations of artistic activities in the mentioned early texts started with a statement that "the (p)lan of cultural propaganda" in previous years "did

\footnotetext{
14 Ibid.

${ }^{15}$ In the research of the archival material, I did not come across any data that would indicate a specific case of using artistic performances abroad to flee the country. However, such cases are reported in the literature. See, for example, Oskar Danon, Ritmovi nemira (zabeležila Svjetlana Hribar) [Rhythms of Restlessness (recorded by Svjetlana Hribar)] (Belgrade: Beogradska filharmonija, 2005), 154-155, 234, 235.

16 On the guest appearances of Yugoslav folk dance ensembles after the breakup with the Soviet Union, see Ivan Hofman, "Uloga muzičkog folklora u spoljnoj politici socijalističke Jugoslavije 1950-1952. [The
} 
not exist at all," with the following criticism pronounced: the contents that could be promoted, or where and how to act was not considered; there was a mistaken belief that the artistic level of Yugoslav composers, reproduction and other artists "did not match the international competition"; the "extensive cultural heritage of our peoples" remained "completely unutilized." 17 That is why the agenda of the new cultural propaganda envisaged multiple types of musical activities to be realized through the promotion of the country's musicians and musical works abroad, guest appearances of foreign musicians in Yugoslavia, the participation of Yugoslav representatives in international music festivals and competitions, as well as various other practices such as broadcasts of Yugoslav music on foreign radio stations.

The plans envisaged that performances abroad should be of high quality and should contribute to the professional development of guest artists, their affirmation in the European framework, as well as the cultural affirmation of the country. Moreover, the tours were to be carefully planned and organized through Yugoslav diplomatic missions in other countries and the state concert agency. Performances on musicians' own initiative were not excluded, but were not recommended, because artists, as it was pointed out, were satisfied with "being paid little by different agencies" and holding "performances at unrepresentative venues," which is "bad for the reputation of the artist and the country." 18 The plans claim that "an artist's name is built gradually, that an artist should be launched while he is still young, that he should be helped, skillfully placed and that connections should be established for him," and confidently conclude that "a whole range of our young artists can create solid artistic prestige soon." 19

The idea of promoting Yugoslav composers' works was emphasized in the projections of musical activity abroad. It was especially stressed in the earliest such plan, where the idea was present in every activity, from foreign performances of music by local artists and specially organized concerts abroad to radio stations in different countries and efforts to "get [...] certain performances of our music introduced into their programs." At the same time, the plan was for all foreign musicians visiting the FPRY to get acquainted with the music by Yugoslav authors, and for a certain priority to be given to those who want to perform and propagate it. Another part of the plans was to explore the possibility of finding "friendly foreign musicologists" interested in writing "about our music." 20

Insisting on works by Yugoslav authors was not surprising if we keep in mind that several representative concerts of Yugoslav music were held in Rome,

\footnotetext{
role of musical folklore in the foreign policy of the socialist Yugoslavia 1950-1952]," in Spoljna politika Jugoslavije 1950-1961, edited by Slobodan Selinić (Belgrade: Institut za noviju istoriju, 2008), 437-456.

17 AJ, 317-86-120, A note on experiences in the field of our cultural propaganda abroad.

18 AJ, 317-86-120, On forms of culture and science propaganda abroad.

${ }^{19} \mathrm{AJ}, 317-86-120$, A note on experiences in the field of our cultural propaganda abroad.

${ }^{20} \mathrm{AJ}, 317-86-120$, On forms of culture and science propaganda abroad.
} 
Vienna, Bern and London in late 1949, about which the professional public in the country was informed in early 1950. ${ }^{21}$ Concerts were organized by the Yugoslav embassies these cities in celebration of Republic Day, November 29. This was the most important public holiday in the FPRY, which symbolized the authenticity of the Yugoslav victory over fascism, and was celebrated abroad with works by contemporary Serbian, Croatian and Slovenian composers in collaborative performances of Yugoslav and foreign musicians. 22 The idea of putting art in the place of political speeches on such occasions proved to be a well-devised step, which created an image of a progressive socialist country among officials and the public, unburdened by the ballast of ideology. ${ }^{23}$ At the same time, the performances themselves made positive impressions. The evaluations of interpretative abilities of young Yugoslav musicians were exceptional and often expressed in superlatives. The critical reviews of the performed works were mostly affirmative, and indicated great interest in learning about the composing traditions of Yugoslavia, represented in these performances by romantic and moderated modernist, mostly folklore-inspired works. Finally, the

\footnotetext{
21 "Jugoslovenski koncerti u inostranstvu povodom 29 novembra [Yugoslav concerts abroad to mark November 29]," Muzika 4 (1950): 123-132. Within this text, several critical reviews from the foreign press about each of the mentioned concerts were reported. It includes translations of reviews from the Berner Zeitung, Berner Tagwacht and Le Sentinel (Bern), Wiener Kurier and Weltpresse (Vienna), Irish Independent (Dublin), Daily Herald, Daily Telegraph and Times (London), Birmingham Mail, Birmingham Post and Glasgow Herald, as well as La liberta d'Italia, Il giornale d'Italia and Quotidiano (Rome).

22 Pianist Ivo Maček and alto Marijana Radev from Zagreb performed at the Bern Conservatory together with local chamber musicians (the program included Josip Slavenski’s String Quartet No. 3, Maček's Intermezzo for piano, Božidar Kunc's Six Bagatelles for piano, Boris Papandopulo's Kontradanca for piano, Ilija L. Marinković’s Wind Quintet, songs of Blagoje Bersa, Jakov Gotovac and Krešimir Baranović, Slavenski’s String Quartet with Alto Pesme moje majke (My Mother Songs). The concert in Vienna was held at the Musikverein. Slovenian conductor Samo Hubad and Zagreb baritone Vladimir Ruždjak performed with the Vienna Symphony Orchestra (three movements from Slavko Osterc's Suite, Lucijan Marija Škerjanc's Symphony No. 5; Krešimir Baranović's song cycle Z mojih bregov (From My Hills), Jakov Gotovac's Simfonijsko kolo (Symphonic kolo). The performance at the Central Hall Westminster was entrusted to the City of Birmingham Symphony Orchestra under its chief conductor George Weldon and Zagreb conductor Milan Horvat, starring pianist Kendal Taylor (Marjan Kozina's symphonic scherzo Bela Krajina (White Carniola), two dances from Stevan Hristićs ballet Ohridska legenda (The Legend of Ohrid), Škerjanc's Piano Concerto in A Minor, Stjepan Šlek's Symphony No. 2). The concert at the Teatro Quirino in Rome was performed by the RAI Chamber Orchestra under the baton of Belgrade conductor Živojin Zdravković and with Belgrade cellist Mirko Dorner and Zagreb soprano Dragica Martinis (Suite from Hristićs Ohridska legenda (The Legend of Ohrid), Symphonic Triptych from Petar Konjović's opera Koštana, Gotovac's Symphonic kolo, songs by Milo Cipra, Božidar Kunc and Blagoje Bersa). Zdravković and Dorner performed with the same orchestra once again, presenting works by Mozart, Schubert and Haydn. ${ }^{23}$ This can clearly be seen from certain comments in the press. For example: "Happy is a republic that, in addition to defending its interests, can deal with the spreading of its culture and art" (Le Sentinel); "Celebrating a national holiday with a concert of contemporary music is without a doubt a sign of good and refined taste and unusual musical feeling" (La liberta d'Italia). "Jugoslovenski koncerti u inostranstvu," 124-125; 129.
} 
concert in London was presented by two prominent British artists who were ready for closer cooperation with Yugoslav musicians. While pianist Kendal Taylor visited the FPRY on several occasions and promoted works by Yugoslav authors, helping organize concerts of Yugoslav musicians in London, conductor George Weldon also performed Yugoslav music and had a major tour in Yugoslavia in the early 1950s, after which he wrote about his positive musical impressions of the country. ${ }^{24}$

The first experiences of the musical breakthrough into the West confirmed that music offered great opportunities for presentation abroad, so the approach taken in further work included versatile planning, more comprehensive activation of musicians and their associations, various activities, with constant self-analysis and a critical attitude toward the achieved results.

\section{Increasing musical activity abroad under the auspices of the Council for Science and Culture of the FPRY Government (1950-1952)}

The newly established Council for Science and Culture, which took over the tasks and competences of the Ministry of Science and Culture, continued to increase the cultural propaganda in its Department for International Cultural Links. ${ }^{25}$ Thanks to numerous reports of the department, as well as individual archival documents related to some musical activities and events, one can gain detailed insight into the types of musical activities abroad and their development in the three-year period starting in $1950 .{ }^{26}$

\footnotetext{
24 See George Weldon, “Impressions of Music in Jugoslavia,” Tempo 15 (1950): 30-31. The same text translated into Serbian was published in Belgrade (Džordž Veldon, "Utisci o muzici u Jugoslaviji," Muzika 5 (1951): 185-187).

25 The President of the Council was Rodoljub Čolaković, who was also the Minister of the previous Ministry of Science and Culture. The head of the Department for International Cultural Links was Franc Drenovec, and after him Vanda Novosel. Various clerks and employees worked at the Department, among whom some were highly educated individuals, such as Kristina Krista Đorđević. Already in the first months of the council's work, senior Department officials held numerous talks with important representatives of the country abroad regarding the cultural policy and on organizing important cultural events in different countries. See, for example, AJ, 317-86-120, General materials on foreign relations, Conclusions of conversations with comrades Ljubo Drndić and Saša Šokorac, September 23, 1950, Belgrade; Note from the meeting on cultural issues 20-IX-50. Representatives of the Council for Science and Culture present: Vanda Novosel and Franc Drenovec. Conversations with Ljubo Drndić (US) and Saša Šokorac (England), September 23, 1950, Belgrade; Notes from the meeting at the Directorate for Information, s. a., Belgrade.

26 The systematization of data presented in the text is based on information from various individual documents, as well as short annual reports, detailed summary reports, analyses and plans on the monthly, quarterly, semi-annual and annual basis, which were carefully written by individual employees of the Department. Among these documents, three short annual reports were also published in Doknić, Petrović, Hofman, Kulturna politika Jugoslavije, Vol. 2, 444-452; 452-456; 459-462.
} 
Participation in international competitions and attendance at foreign festivals were a significant part of the work through which the Department implemented the policy of supporting promising, primarily young musicians, intending to provide them with financial support and organizational training and professional competition in a broader international framework. ${ }^{27}$

Most young artists were interested in one of the leading international competitions held in Geneva (Concours international d'exécution musicale de Genève). The first successes of Yugoslav musicians-Mirko Dorner (cello) and Mariana Radev (solo singing), who won first prizes in their respective categories in 1949-probably contributed to that. As many as eleven Yugoslav candidates participated in the same competition in 1950 . However, given their poor results, ${ }^{28}$ the Council concluded that the success of these artists was not commensurate with the large material costs set aside for the Geneva competition, that the poor results showed insufficiently strict selection criteria for candidates, and that some artists did not have time to prepare adequately for the competition. Therefore, the criteria for sending musicians to this competition were tightened in the following years, so better results were subsequently recorded. ${ }^{29}$

Renowned international competitions in Italy, Belgium, France and Great Britain also attracted the attention of young Yugoslav musicians. In the observed period, there was only one poor result, while all other participations testified to the higher artistic quality of the Yugoslav candidates in relation to their competitors from other countries. ${ }^{30}$ The greatest success was achieved at the competition in Belgium (Concours international de chant de Verviers), which showed that Yugoslavia had a significant number of excellent young singers. The large team of Yugoslav participants, with individuals taking all the first prizes, caused a sensation

27 See AJ, 317-86-120, General materials on foreign relations, Report on the work of the Department for International Cultural Links for 1950, s. a., Belgrade; Annual report for 1951, November 19, 1951, Belgrade; Annual report for 1952, s. a., Belgrade.

${ }^{28}$ No candidate was awarded, only violinist Igor Ozim and singers Ana Lipša and Miroslav Čangalović received medals.

${ }^{29}$ In 1951, three candidates went to Geneva (Zorica Filipović, Dragutin Mirković and Fredi Došek), of whom opera singer Zorica Filipović got into the finals of the competition. The following year, six musicians participated (Olga Jovanović, Branko Pajević, Ela Kovačević-Štajner, Zvjezdana Bašić, Jelka Krak-Stanić and Sonja Draksler). Out of 80 pianists, Olga Jovanović won third place and Sonja Draksler came in fourth. Branko Pajević was tenth out of a total of 46 violinists.

${ }^{30}$ Violinist Josip Klima from Zagreb was eliminated in the first round at the Marguerite LongJacques Thibaud Competition in Paris. Both performances of Yugoslavs in the competition in Vercelli (Concorso Internazionale di Musica Viotti in Vercelli) resulted in the highest awards: in 1950, among young composers Vlastimir Peričić, a student of the Music Academy in Belgrade, received a cash prize for his String Quartet, while the duo Ivo Maček and Mirko Dorner won first prize in the chamber music category in 1952. Violinist Igor Ozim, who competed in the Carl Flesch International Violin Competition during his studies in London, won the first and only prize in that competition in 1951. 
among the Belgian public. The press published very favorable reviews about them, emphasizing the dedication of the approach to young talents in the FPRY. ${ }^{31}$

The presence of Yugoslav artists at international music festivals, as well as summer courses held as part of those events, provided an exceptional opportunity to establish professional ties and meet prominent world musicians and music educators. Such cultural events provided opportunities to attend a large number of high-quality musical performances in a short period of time, which was of particular interest for gaining insight into the contemporary music trends at the international level. Yugoslav musicians were initially referred primarily to the Salzburg Festival. ${ }^{32}$ However, the Council for Science and Culture quickly adopted expert opinions on the importance of visits to various events of this type, so the list of festivals was significantly longer in 1952, with the idea of musicians "expanding their artistic horizons and sharpening their criteria in making assessments of new works and performing arts in general." 33

\footnotetext{
31 Valerija Hejbalova, Nada Putar, Tomislav Neralić, Jeronim Žunec, Ratimir Delorko, Miroslav Čangalović, Janez Lipušček, Rudolf Francl and Vladimir Ruždjak participated in the competition. Awards went to Ruždjak, Lipušček, Neralić and Putar, as well as Hejbalova, who also received a great honorary award.

32 As many as 20 musicians from Belgrade, Zagreb, Ljubljana, Sarajevo and Skopje took part in the Salzburg Festival in 1950 (Mihailo Vukdragović, Mladen Babić, Silvio Bombardeli, Mladen Jagušt, Svetislav Stančić, Vaclav Huml, Emil Hajek, Kiril Spirovski, Todor Skalovski, Vlada Marković, Ivan Pinkava, Jelka Stančić-Krek, Hinko Leskovšek, Dušan Skovran, Samo Hubad, Dimitirije Žerbe, Frederik Lupša, Vlado Korošec, Elza Karlovec and Dragotin Cvetko). That year, Mirko Dorner was an assistant to Italian cellist Enrico Mainardi, who visited Yugoslavia on several occasions. Only Stanojlo Rajičić, Marjan Burić and Dušan Miladinović attended the festival in Salzburg in 1951. See AJ, 317-86-120, General materials on foreign relations, Report on the work of the Department for International Cultural Links for 1950, s. a., Belgrade; Annual report for 1951, November 19, 1951; AJ, 317-5-12, Confidential relations with Austria, Letters of F. Drenovec, the Head of the Department for International Cultural Links, sent to the Ministries of Culture of Serbia, Croatia, Slovenia and Macedonia in June 1950, with lists of artists who go to the festival in Salzburg and summer courses that are held as part of the festival in June-August 1950.

${ }^{33}$ AJ, 317-86-120, Annual report for 1952. In 1952, Yugoslav musicians attended festivals in Florence (Ciril Cvetko from Maribor and Jeronim Žunec from Zagreb), Vienna (Boris Papandopulo from Sarajevo), Salzburg (Lazar Marjanović and Milutin Radenković from Belgrade and Gligor Smokvarski from Skopje), Lucerne (Josip Andreis and Dimitrij Žerbe from Zagreb), Edinburgh (Predrag Milošević from Belgrade and Ivo Maček from Zagreb) and Bayreuth (Dragutin Bernardić from Zagreb and Rudolf Francl from Ljubljana). Ibid.; data in the correspondence AJ, 317-86-120, General materials on foreign relations, Zoja Levi from the Department for International Cultural Links to the Union of Music Artists of Yugoslavia, Subject: Musical manifestations abroad, V. 4266, June 18, 1952, Belgrade; K. Đorđević, Deputy Head of Department for International Cultural Links, to the Council for Education, Science and Culture of the Republic of Serbia, Subject: Sending artists to festivals abroad, V. 4120, June 17, 1952, Belgrade; K. Đorđević to the Council for Education, Science and Culture of the Republic of Slovenia, Subject: Selection of candidates for international musical festivals abroad, V. 4595, June 18, 1952, Belgrade; K. Đorđević to the Union of Composers of Yugoslavia, Subject: Sending our artists to musical manifestations abroad, V. 4533, June 17, 1952, Belgrade; R. Čolaković, Minister, to the Secretary General of the FPRY Government, Subject: Departure to the music festival in Salzburg, V. 4598, June 17, 1952.
} 
The procedure for selecting candidates for competitions and festivals was complex in a bureaucratic sense, and included various instances at the level of ministries and music associations of the republics, as well as federal music associations. Although the council had the final say in decision making, opinions received from the Association of Yugoslav Composers and the Association of Yugoslav Music Artists were respected unless the proposed candidates had a "problematic" political past. In addition, the number of proposed candidates was usually higher than the planned material expenditures of the department, so the council had the decisive word in that regard as well. ${ }^{34}$

The annual festivals and conferences of the International Society for Contemporary Music (ISCM) were of particular importance for Yugoslav composers. Since the Yugoslav section of the ISCM was active already before WWII, contacts with that association were renewed in 1950. Milenko Živković and Natko Devčić were present at the 1950 festival and conference of the ISCM in Brussels, and only Živković in Frankfurt in 1951. Živković negotiated very actively with some of the national sections at the conference for performing contemporary Yugoslav music at the annual ISCM festivals. The following year, at the ISCM festival in Salzburg, the program included the Symphonic Antithesis by Matija Bravničar and the Sonata for Violin and Organ by Josip Slavenski, with both composers present. ${ }^{35}$

Živković himself published a detailed report on his stay in Brussels, including a review of trends in contemporary music, from which Yugoslav composers were cut off during the post-war years. Although Živković openly distanced himself from the creative lines in the wake of the Schoenberg tradition, his discourse was also far from socialist realism. The concluding message of his text indicates his closeness to the new course of official cultural policy, developed precisely through artistic representation abroad:

\footnotetext{
${ }^{34}$ Compare, for example, the number and composition of candidates who visited festivals in 1952 (see footnote 33) with the lists proposed by the musical associations: AJ, 317-86-120, General materials on foreign relations, Vladimir Marković, Deputy Secretary General of the Union of Music Artists of Yugoslavia, to the Department for International Cultural Links (for comrade Zojica Levi), Subject: International musical manifestations, No. 183, June 2, 1952, Belgrade; Lazar Maksin, Assistant to the President of the Council for Education, Science and Culture of the Republic of Serbia, to the Council for Science and Culture of the FPRY Government, No. 9530/II, May 30, 1952, Belgrade. See also the documents mentioned in AJ, 317-5-12, Confidential relations with Austria, and AJ, 317-86-120, General materials on foreign relations, Monthly report for June 1951, signed by Milena Nikolić, s. a., Belgrade.

${ }^{35}$ See AJ, 317-86-120, Report on the work of the Department for International Cultural Links for 1950, s. a., Belgrade; Annual report for 1951, November 19, 1951, Belgrade; Annual report for 1952, s. a., Belgrade; Stevan Hristić, President of the Union of Composers of Yugoslavia, to the Department for International Cultural Links, No. 81/51, April 17, 1952, Belgrade; V. Novosel, Head of the Department for International Cultural Links, to the Union of Composers of Yugoslavia, Subject: International Society for Contemporary Music Festival and International Congress of Composers in Salzburg, V. 2908, April 29, 1952, Belgrade.
} 
Today, when Yugoslavia is gaining an increasingly important role in international politics, it is clear that we cannot remain enclosed by the Great Wall of China from the cultural events around us. We would make an unforgivable cultural mistake if we closed our eyes (more precisely, our ears) to today's music of the West, that is, if we passed by and ignored the contemporary artistic issues of Western European music-no matter how different they are (if they are in fact different) from our artistic and ideological aspirations and foreign to our needs. But we would, on the other hand, be just as fatally wrong if we accepted without any criticism everything coming from there. What we need first of all is clear perspective for choosing the positive achievements from contemporary music, then awareness of our own values and confidence in our own strengths [...]. ${ }^{36}$

In the reports, plans and reviews of the work of the Department for International Cultural Links of the Council for Science and Culture, concerts and concert tours of Yugoslav musicians and ensembles were among the main forms of musical propaganda abroad. However, it was often pointed out that the department did not have full insight into this type of musical activity, because some musicians arranged their trips on their own. In such circumstances, the Council occasionally intervened to arrange visas, or assisted in other ways. For example, pianist Melita Lorković used her own connections when arranging a tour of Finland, Sweden, England, the Netherlands and Switzerland in 1951. On that occasion, the Council sought approval for her trip abroad from the General Secretariat of the Government and ordered Yugoslav missions in the respective countries to meet Lorkovićs needs when organizing her concerts and radio appearances. ${ }^{37}$ It also helped Melanija Bugarinović, Drago Kunc and the young Milan Horvat, who quickly established his own musical connections and began touring Europe intensively. ${ }^{38}$ Also, Marijana Radev had numerous artistic acquaintances, which enabled her to organize guest appearances abroad. ${ }^{39}$

The work of the Council in this area was based on the policy of helping young and promising artists get recognized abroad, affirm themselves and get in touch

\footnotetext{
${ }^{36}$ Milenko Živković, "Pogled na savremenu muziku Zapada - Povodom XXIV festivala Međunarodnog društva za savremenu muziku u Briselu [A look at the contemporary music of the West-On the occasion of the $24^{\text {th }}$ Festival of the International Society for Contemporary Music in Brussels]," Muzika 5 (1951): 170.

37 AJ, 317-86-120, General materials on foreign relations, Work report for February 1951-Music and folklore ensembles, Belgrade, s. a.

${ }^{38}$ For example, the Council granted Horvat a foreign currency allowance for traveling to performances in Bordeaux and London in April 1951, as the fee offered to him did not cover travel expenses. AJ, 317-86-120, General materials on foreign relations, Work report for March 1951.

39 On this, as well as Radev's appearances in Italy in 1950, see AJ, 317-6-15, Confidential relations with Italy. Obren Milićević, Press Advisor, to the Directorate for Information of the FPRY Government, Subject: Report on the stay of Yugoslav artists in Rome, Conf. no. 32, July 24, 1950, Rome.
} 
with foreign concert agencies and relevant musical circles. In this sense, a concert by Milan Horvat was organized at the opening of an exhibition of medieval art in Paris in March 1950. In August the same year, a big tour of Yugoslav opera singers was carried out in Israel. That was followed by the presentation of young contestants in Geneva at a concert for the diplomatic corps and cultural staff (September). A concert of Yugoslav music by Mirko Dorner and Stanoje Janković was held in Vienna (October), while Živojin Zdravković conducted the Helsinki Symphony Orchestra, performing works by Yugoslav authors (November). ${ }^{40}$ The following year, performances by Valerija Hejbalova and Vladimir Ruždjak took place in London (February), a concert by Anita Mezetova and Miroslav Čangalović was held in Vienna on the occasion of Republic Day (November 29), and a concert by Vladimir Ruždjak and Ivo Maček was organized in Paris (December). ${ }^{41}$ In 1952, the number of concerts increased significantly, which, along with several guest appearances by Yugoslav singers on opera stages, testified to the expansion of the geographical focus of musical performances, including to centers in Greece, Austria, Finland, Sweden, Norway, France, and Germany. 42

The performances of the Ballet of the Belgrade National Theatre at the Edinburgh International Festival for Music and Drama (August 20 to September 8, 1951) was the largest project of Yugoslav music performances abroad realized through the Council in the given period. During the festival, the ballet Ohridska legenda (The Legend of Ohrid) by Serbian composer Stevan Hristić was performed eight times, and an additional show included scenes from two ballets by Croatian composers, Licidersko srce (Gingerbread Heart) by Krešimir Baranović and Balada o jednoj srednjovjekovnoj ljubavi (A Ballad of a Medieval Love) by Fran Lhotka. ${ }^{43}$

\footnotetext{
40 AJ, 317-86-120, Report on the work of the Department for International Scientific and Cultural Links in 1950, Belgrade, s. a.

${ }^{41}$ AJ, 317-86-120, Annual report for 1951, Belgrade, November 19, 1951.

42 These were guest appearances by the following artists: Miroslav Čangalović (participated in a symphonic concert in Vienna on January 13), Marijana Radev (five performances in Greece in January-February, a guest performance in Vienna in March), Živojin Zdravković (two performances in Finland in January, two recordings for a Swedish radio station in February, concerts in Stockholm, Oslo and Paris in November-December), Mirko Dorner (concerts in Stuttgart on May 28 and 29), members of the Slovenian Trio (concerts in Graz and Vienna in December), Stanoje Janković (seven performances at the Athens Opera), Nikola Cvejić (sang in the opera Tosca in Graz), Aleksandar Marinković (sang in the opera La bohème at the Vienna State Opera on February 6), Jovan Gligorijević (sang in the opera Rigoletto in the Vienna State Opera in February). AJ, 317-86-120, Annual report for 1952, Belgrade, s. a.

${ }^{43}$ The Belgrade ballet troupe also comprised individual dancers from Zagreb and Ljubljana. Hristić and Oskar Danon conducted the Scottish National Orchestra. The choreography of Hristićs ballet was prepared by Margarita Froman, the stage design by Staša Beložanski, and the costumes by Milica Babić-Jovanović. Dimitrije Parlić performed the scenes from Baranovićs, and Pia and Pino Mlakar from Lhotka's ballet.
} 
The reason for organizing the whole project was the interest in Hristićs ballet, which was later performed all over Europe. ${ }^{44}$ Both before and after the visit to Edinburgh, representatives of music festivals, impresarios and concert agency managers were coming to Belgrade, Zagreb and Ljubljana to see ballet and opera performances. At first, their attention was focused on ballets, among which Hristićs work was their first choice. However, it seems that the Embassy in London was one of the initiators of foreign interest in that ballet because it started promoting it already in 1949, which stimulated the curiosity of the Edinburgh Festival Board in December that year. It was the persistence of the embassy staff to overcome organizational obstacles and, in a way, discipline the insufficiently organized staff of the federal Ministry of Culture in Belgrade, which was crucial for the subsequent processes of negotiations regarding the visit of the Belgrade Ballet. ${ }^{45}$ The embassy was also the primary mediator in connecting the officials of the festival with the Council for Science and Culture. This way, with the visit of Sir Andrew Murray, Lord Provost of Edinburgh, and William P. Earsman in Belgrade in early 1951, the phases of more intensive arrangements for a performance at the festival began, joined also by Ian Hunter, the artistic director of the festival, and Oskar Danon, the director of the Belgrade Opera, as well as other representatives of the National Theatre in Belgrade. ${ }^{46}$

The Belgrade Ballet received a warm welcome in Edinburgh. The audience and the reviews for the broader readership indicated very favorable reactions, while professional critics also had objections regarding the music, decor and choreography. ${ }^{47}$ It turned out, however, that Hristićs ballet was an excellent choice of music and stage work for foreign audiences. Already at that time, the demand for the work existed in Italy, Belgium, France, Argentina and other countries. In this sense, for example, the manager of the National Theater in Belgrade, Milan Bogdanović, held negotiations with the Théatre National Belgique, whose representatives, along with the director of the Centre belge des échanges culturels internationaux, Maurice Huisman, were

\footnotetext{
${ }^{44}$ It should be noted that this work was first performed abroad by the Ljubljana Ballet as guest performances in Graz and Klagenfurt in 1950. On the numerous stagings and foreign presentations of this ballet, see Ani Radošević, O scenskim izvođenjima "Ohridske legende" Stevana Hristića (About the Stagings of the The Legend of Ohrid by Stevan Hristić), prepared by Nadežda Mosusova (Belgrade: Muzikološki institut SANU, 2017).

${ }^{45}$ For details see AJ, 317-5-14, Confidential relations with Great Britain, An elaborate report by Obrad Cicmil, Yugoslav Ambassador in London, sent to the Minister Rodoljub Čolaković, Conf. no. 30/50, January 13, 1950, London; A note regarding the letter from the FPRY Embassy in London, signed by Drenovec, January 26, 1950, Belgrade.

${ }^{46}$ See various documents in AJ, 317-5-14, Confidential relations with Great Britain, as well as annual and monthly reports on the work of the council in AJ, 317-86-120, General materials on foreign relations.

${ }^{47}$ Quotations from a review in the Edinburgh Evening News are published in Radošević, O scenskim izvodenjima, 26. A selection of critical reviews of the performance in Edinburgh can be found in AJ, 317-97-144, Relations with Great Britain.
} 
interested a performance of Ohridska legenda in Brussels and Antwerp. ${ }^{48}$ However, activities related to new guest performances of the ballet were halted by Belgrade itself, and until the end of 1952, the Belgrade Ballet only performed abroad one more time, in Athens. ${ }^{49}$ The main reasons were technical and financial, because the Council did not have the funds to finance a trip of a large ballet troupe, even partially. ${ }^{50}$ In order for guest performances of the ensemble and its technical support to pay off, it was necessary to organize a series of performances at several different locations. The Belgrade National Theatre itself had no possibility for such endeavors, since, in addition to scarce resources in terms of stage sets, it was also short in the number of performers. The entire ensemble was not large enough, and an extended absence of the ballet troupe would leave no repertoire alternative.

In conclusion, it is important to stress that the case of Ohridska legenda reflected a very complicated and difficult situation in the country itself. Although the share of the country's budget reserved for culture was constantly increasing, ${ }^{51}$ it was necessary to invest more in musical resources within the country itself. These improvements had be done very soon in crucial musical institutions, such as symphony orchestras and opera houses in Belgrade, Zagreb and Ljubljana, so that they would be able to manage a series of guest performances abroad in the next decades. The early period of turning to the West, which was analyzed here, set the preconditions for such a cultural momentum. Between 1949 and 1952, many crucial and most difficult steps were taken in breaking through the preceding international isolation. The foundations were laid for increasingly liberal activities in culture, which also reflected from the sphere of foreign policy to the internal one.

As the only country of the Eastern Bloc that managed to oppose Soviet influence and try to build its own path to socialism, Yugoslavia strategically became a partner of Western democracies. It dealt with difficult economic conditions, and gradually established important economic ties with key Euro-Atlantic countries, receiving both annual cash loans and grants. This was the beginning of advocating its "neutrality" and successful balancing between the blocs, with culture (and music) on its forefront. In this context, music was used as a tool of soft power in a very skillful manner. The short period between 1949 and 1952 was the outset of growing musical collaboration and exchange of ideas with the world.

\footnotetext{
48 Documentation on these negotiations can be found in AJ, 317-5-13, Confidential relations with Belgium and the Netherlands.

${ }^{49}$ No information about the trip was found in the archival documentation. However, it was mentioned in Radošević, O scenskim izvođenjima, 26-27, and in Danon, Ritmovi nemira, 232-234.

50 The stay, trip and per diem allowances of the participants at the festival in Edinburgh were covered by the organizers. The council provided the necessary loans for the transport of the equipment (111,191 dinars), which was shipped in both directions by train.

${ }^{51}$ For example, from the previous $2.6 \%$, the budget for culture increased to $4 \%$ in 1952, and the largest share of this was spent on guest appearances abroad. Doknić, Petrović, Hofman (Eds.), Kulturna politika Jugoslavije, Vol. 1, 39.
} 


\section{Primary sources:}

Archives of Yugoslavia (AJ) (Belgrade): The FPRY Government's Council for Science and Culture

\section{References:}

Ahrendt, Rebekah, Ferraguto, Mark, Mahiet, Damien (Eds.). Music and Diplomacy from the Early Modern Era to the Present. New York: Palgrave Macmillan, 2014.

Alloul, Houssine, Auwers, Michael. "What is (New) Diplomatic History?" Journal of Belgian History 48/4 (2018): 112-122.

Bondžić, Dragomir. Misao bez pasoša: međunarodna saradnja Beogradskog univerziteta 1945-1960. Belgrade: Institut za savremenu istoriju, 2011. [Orig. in Serbian Cyrillic]

Cvetković, Vladimir L. Pogled iza gvozdene zavese. Jugoslovenska politika prema zemljama narodne demokratije u susedstvu 1953-1958. godina. Belgrade: Institut za savremenu istoriju, 2013.

Danon, Oskar. Ritmovi nemira (zabeležila Svjetlana Hribar). Belgrade: Beogradska filharmonija, 2005.

Dimić, Ljubodrag. Agitprop kultura. Agitpropovska faza kulturne politike u Srbiji 1945-1952. Belgrade: Rad, 1988.

Doknić, Branka, Petrović, Milić F., Hofman, Ivan (Eds.) Kulturna politika Jugoslavije 1945-1952. Zbornik dokumenata, Vols. 1-2. Belgrade: Arhiv Jugoslavije, 2009. [Orig. in Serbian Cyrillic]

Doknić, Branka. Kulturna politika Jugoslavije 1946-1963. Belgrade: Službeni glasnik, 2013. [Orig. in Serbian Cyrillic]

Hofman, Ivan. "Uloga muzičkog folklora u spoljnoj politici socijalističke Jugoslavije 1950-1952." In Spoljna politika Jugoslavije
1950-1961, edited by Slobodan Selinić, $437-$ 456. Belgrade: Institut za noviju istoriju, 2008.

"Jugoslovenski koncerti u inostranstvu povodom 29 novembra." Muzika 4 (1950): 123-132. [Orig. in Serbian Cyrillic]

Medić, Ivana. “The Ideology of Moderated Modernism in Serbian Music and Musicology," Muzikologija 7 (2007): 279-294.

Mikić, Vesna. "Aspects of (Moderate) Modernism." In Rethinking Musical Modernism, edited by Dejan Despić and Melita Milin, 187-193. Belgrade: Serbian Academy of Sciences and Arts, Institute of Musicology SASA, 2008.

Milanović, Biljana. "Musical Representation of Mokranjac and the Belgrade Choral Society as a Form of Cultural Diplomacy." In Stevan Stojanović Mokranjac (1856-1914): The Belgrade Choral Society Foreign Concert Tours, edited by Biljana Milanović, 11-42. Belgrade: Institute of Musicology SASA, Serbian Musicological Society, 2014.

Milin, Melita. Tradicionalno i novo u srpskoj muzici posle Drugog svetskog rata (1945-1965). Belgrade: Muzikološki institut SANU, 1998. [Orig. in Serbian Cyrillic]

Milin, Melita. "Etape modernizma u srpskoj muzici." Muzikologija 6 (2006): 93-116. [Orig. in Serbian Cyrillic]

Petrović, Vladimir. Jugoslavija stupa na Bliski istok: stvaranje jugoslovenske bliskoistočne politike 1946-1956. Belgrade: Institut za savremenu istoriju, 2007. 
Prévost-Thomas, Cécile, Ramel, Frédéric. "Introduction: Understanding Musical Diplomacies-Movements on the 'Scenes.' In International Relations, Music and Diplomacy, Sounds and Voices on the International Stage, edited by Frédéric Ramel, Cécile Prévost-Thomas, 1-19. London: Palgrave Macmillan, 2018.

Radošević, Ani. O scenskim izvođenjima "Ohridske legende" Stevana Hristića, prepared by Nadežda Mosusova. Belgrade: Muzikološki institut SANU, 2017. [Orig. in Serbian Cyrillic]

Scott-Smith, Giles, Weisbrode, Kenneth. "Editorial." Diplomatica: A Journal of Diplomacy and Society 1/1 (2019): 1-4.
Selinić, Slobodan (Ed.). Spolina politika Jugoslavije 1950-1961. Belgrade: Institut za noviju istoriju, 2008.

Weldon, George. "Impressions of Music in Jugoslavia." Tempo 15 (1950): 30-31. / Veldon, Džordž. "Utisci o muzici u Jugoslaviji." Muzika 5 (1951): 185-187). [Orig. in Serbian Cyrillic]

Živković, Milenko. “Pogled na savremenu muziku Zapada - Povodom XXIV festivala Međunarodnog društva za savremenu muziku u Briselu." Muzika 5 (1951): 170. [Orig. in Serbian Cyrillic] 


\title{
"Folklore diplomacy" - the role of musical folklore in Yugoslavia’s foreign policy 1949-1971
}

\author{
Ivan Hofman
}

Our cultural-propaganda activity should affirm the culture of our country in the European framework, and even beyond it, and through various forms popularize our socialist country, the cultural heritage of our peoples, our new art, cultural life and the artistic development in our country. In our cultural propaganda, we should actively participate in the general ideological fight at the cultural front. In that fight, Yugoslavia should take the same position and role as it did in the general revolutionary fight. ${ }^{1}$

When it became clear in 1949 that the breakup with the Cominform was final and that, due to the blockade imposed by its former allies, the survival of the country was called into question, the top echelon of the Communist Party of Yugoslavia concluded that the only way out was to turn to its ideological nemesis-the liberal capitalist West, spearheaded by the United States of America. The US was determined to use "the Yugoslav schism," and in 1950 the two countries concluded several arrangements which helped Yugoslavia out of its isolation and created conditions for the country to initiate an independent and ambitious foreign policy, which holds in its foundation the authentic Yugoslav revolution. ${ }^{2}$

However, in order to pursue an active foreign policy, certain means are needed. Sometimes this includes the capital at the disposal of a certain country and other times the strength of its army. In the case of socialist Yugoslavia, which

1 The Archives of Yugoslavia [Arhiv Jugoslavije (AJ)], The FPRY Government’s Council for Science
and Culture [Komitet za nauku i kulturu vlade FNRJ] (317), box no. 86, archival unit 120, Goals and
tasks of cultural propaganda of the FPRY, 1949, Belgrade; Branka Doknić, Milić F. Petrović, Ivan
Hofman (Eds.), Kulturna politika Jugoslavije 1945-1952. Zbornik dokumenata II [Cultural policies
of Yugoslavia 1945-1952. Collection of Documents II] (Belgrade: Arhiv Jugoslavije, 2009), 436.
2 Dragan Bogetić, Jugoslavija i Zapad 1952-1955: jugoslovensko približavanje NATO-u [Yugoslavia
and the West 1952-1955: Yugoslav rapprochement with NATO] (Belgrade: Službeni list SRJ, 2000);
Darko Bekić, Jugoslavija u Hladnom ratu [Yugoslavia in the Cold War] (Zagreb: Globus, 1988); Bojan
Dimitrijević, “Jugoslavija i NATO 1951-1958, skica intenzivnih vojnih odnosa [Yugoslavia and NATO
1951-1958, a sketch of the dynamic military relations]," in Spoljna politika Jugoslavije 1950-1961,
zbornik radova, edited by Slobodan Selinić (Belgrade, Institut za noviju istoriju Srbije, 2008), 255-274. 
was burdened by inherited poverty and had not recuperated from the destruction of the WWII, it was culture. In March 1950, Yugoslavia presented itself with an exhibition of medieval art of Yugoslav peoples in Paris. Distinguished artists, such as Petar Lubarda, started intensively exhibiting their work at the Venice Biennale and other prestigious manifestations. The works of two leading authors of this era-Ivo Andrić and Miroslav Krleža-were systematically translated into many languages and marketed abroad, while the comedy Dundo Maroje (Uncle Maroye) by Marin Držić and the ballet Ohridska legenda (The Legend of Ohrid) by Stevan Hristić were performed at the Edinburgh Festival and on other great stages. ${ }^{3}$

Regardless of how good it was, Yugoslav elite art still lagged behind the works of great European nations and cultures. However, what they did not have was the authentic musical folklore of Yugoslav peoples. Folk music, purified of the deleterious impact of class society and foreign cultures, was viewed by Marxist musicology as one of the foundations of musical art in socialism. 4 Therefore, Yugoslav ethnomusicologists had the task of participating in the formation of professional ensembles which would raise the musical folklore of its peoples to a higher artistic level and present it to the world. This was the reason why the National Folk Song and Dance Ensemble of the People's Republic of Serbia-later simply named "Kolo"-was established in 1948, followed by the foundation of the National Folk Dance Ensemble of the People's Republic of Croatia ("Lado") and the National Ensemble for Folk Dances and Songs of the People's Republic of Macedonia ("Tanec") in 1949. ${ }^{5}$ These three ensembles and several high-quality amateur ones initiated in 1950 a series of tours abroad, and thanks to them musical folklore became one of the most important instruments in Yugoslav foreign policy. On the following pages, the characteristic performances of these ensembles, which clearly demonstrate their foreign policy role, will be presented. The chronological framework (1949-1971) encompasses the period during which cultural cooperation and exchange between Yugoslavia and foreign countries was within the jurisdiction of the federal administration. ${ }^{6}$

3 Miroslav Perišić, "Veliki zaokret 1950: Jugoslavija u traganju za vlastitim putem. Kultura oslonac, prethodnica i sastavni deo spoljne politike [The great turn of 1950: Yugoslavia in the search for its own path. Culture - the basis, precedent and integral part of foreign policy]," in Pisati istoriju Jugoslavije: viđenje srpskog faktora, edited by Mile Bjelajac (Belgrade, Institut za noviju istoriju Srbije, 2007), 237-279.

4 Ivan Hofman, "Pod stegom Partije. Muzika socijalističkog realizma - primeri SSSR i Jugoslavije [Under the Party's pressure. The music of socialist realism - the examples of the USSR and Yugoslavia]," Godišnjak za društvenu istoriju 1-3 (2005): 41-65.

5 See web pages: http://kolo.rs/, https://www.lado.hr/ and http://www.tanec.com.mk/ (accessed July 27,2019$)$. The ensembles got their current names in 1955 , so they could be easily distinguished abroad. The names Kolo, Lado and Tanec are used in this paper for the same practical reasons.

6 Originally via the Department for International Scientific and Cultural Links of the Ministry of Science and Culture of the Federal People's Republic of Yugoslavia (FPRY) Government (1949-1950), 
The musical folklore of Yugoslav peoples was first officially presented abroad in 1950. A combined ensemble consisting of the members of Kolo and Lado (a total of 150 people) toured Switzerland in the spring, performing in Zurich, Basel, Lausanne and Geneva. The tour was seen as a success from the propaganda and political point of view. The audience was thrilled by what it saw, and the ensemble received invitations to perform in Switzerland again the following year. However, the organization of the tour was deemed poor. The ensemble was given poor-quality halls, and the money earned from the concerts was spent on renting venues. ${ }^{7}$

The annual International Eisteddfod festival was first held in the Welsh town of Llangollen in July 1947. Based on the traditions of the Welsh eisteddfodaucompetitions in Celtic poetry, music and dance-the festival was an international competition of amateur folk dance ensembles and choirs, which gained the reputation of one of the most prestigious festivals in the world in quite a short amount of time. ${ }^{8}$ Encouraged by the success of the tour in Switzerland, the FPRY Council for Science and Culture decided to send a combined ensemble of Tanec and Lado (a total of around 60 people) to Llangollen in 1950. The Macedonian section of the ensemble performed an impressive dance Teškoto (the Hard One) and won first prize. Frula (Tin whistle) players took second place, while the Croatian part of the ensemble won third place performing their own folk songs and dances. The representatives of the International Folk Music Council, headquartered in London, watched the performances. It was then that the connections were made that led to Yugoslavia hosting the congress of this organization in Opatija in September 1951, along with an accompanying festival of selected domestic ensembles. ${ }^{9}$ After

the same department at the Council for Science and Culture of the FPRY Government (1950-1953), and later via the Commission for International Cultural Links as an independent administrative body (named the Federal Commission for International Cultural Links in 1965). The Federal Commission was abolished at the end of 1971 with the reorganization of the federal administration within a set of measures whose goal was to decentralize (confederate) the Yugoslav federation. The administrative bodies of the republics and provinces of the Socialist Federal Republic of Yugoslavia (SFRY) took over the most important jobs regarding the organization of cultural cooperation and exchange with foreign countries. See Ivan Hofman, "Savezna komisija za kulturne veze sa inostranstvom 1953-1971 (1946-1971). Ustanova i njena arhivska građa [The Federal Commission for International Cultural Links 1953-1971 (1946-1971). The institution and its archival material]," Arhivistika: http://www. arhivistika.edu.rs/clanci/sredivanje-i-obrada-arhivske-grade/.

7 AJ, 317-86-120, Report on the work of the Department for International Scientific and Cultural Links in 1950, 1950, Belgrade; Doknić, Petrović, Hofman, Kulturna politika Jugoslavije, 448.

8 On the festival in Llangollen, see https://international-eisteddfod.co.uk/ (accessed July 27, 2019).

9 Ivan Hofman, "Uloga muzičkog folklora u spoljnoj poltici socijalističke Jugoslavije 1950-1952 [The role of musical folklore in the foreign policy of the socialist Yugoslavia 1950-1952]," in Spoljna politika Jugoslavije 1950-1961, 437-456. 
Llangollen, the joint ensemble held several concerts in Wales, mostly in front of representatives of the working class, and it even held a concert in London. ${ }^{10}$

Following the success in Llangollen, Yugoslav ensembles were invited to new tours in Great Britain. In January 1951, Tanec appeared at the prestigious Royal Albert Hall, performing a predominantly Macedonian program: the Hard One, the Diggers' Dance, the Dance from Berat, the Boys' Dance and the Bandits' Dance. The Kolo ensemble performed in Austria in March the same year, "without financial expenses on our side," and then competed in Llangollen, winning first prizes in three categories: dance, song and music. The audience was thrilled, but the critics found fault in the fact that the ensemble, even though professional, competed in an amateur festival. ${ }^{11}$ After Llangollen, Kolo performed at the London Royal Festival Hall and with the mediation of a manager of questionable reputation, J. de Bliek, it also performed in the Netherlands. ${ }^{12}$

In 1952, the three professional ensembles and the Ivo Lola Ribar Academic Cultural Artistic Society from Belgrade, as one of the leading amateur ensembles, had noteworthy performances in the United Kingdom, France, the Netherlands, Greece, on the Free Territory of Trieste and in Scandinavian countries. ${ }^{13}$ Finally, in July 1953, Yugoslav folk dance once again triumphed in Llangollen. This time, a mixed group consisting of about 15 dancers and musicians from Belgrade and Subotica performed. Despite the small number of dancers, the group managed to win the category of folk dances, performing the powerful Warrior Dance of Rugovo (from the Kosovo and Metohija Region) and the Bunjevac Dance. It is interesting that the main competitor of the Yugoslav ensemble was the ensemble of Ukrainian emigrants. ${ }^{14}$

The available sources on the first performances of folk dance ensembles abroad, whether they include correspondence on organizational issues or reports after returning from tours, rarely reflect on the little man, i.e. the ordinary member of the ensemble. But those were young people who, almost certainly, had never had the chance to go abroad before. We suppose that they, as most young Yugoslavs of that generation, believed in the idea of socialism; they believed that they were building a better and more just world than the one they remembered from their childhood,

\footnotetext{
$\overline{10}$ AJ, 317-86-120, Report on the work of the Department for International Scientific and Cultural Links in 1950, 1950, Belgrade; Doknić, Petrović, Hofman, Kulturna politika Jugoslavije, 448.

11 AJ, 317-86-120, Annual report of the Department for International Scientific and Cultural Links for 1951. November 19, 1951, Belgrade; Doknić, Petrović, Hofman, Kulturna politika Jugoslavije, 452. 12 On Kolo's tour and disputes with the manager see the aforementioned paper by Hofman.

${ }^{13}$ AJ, 317-86-120, Annual report of the Department for International Scientific and Cultural Links for 1952, 1952, Belgrade; Doknić, Petrović, Hofman, Kulturna politika Jugoslavije, 459.

${ }^{14} \mathrm{AJ}$, Federal Commission for International Cultural Links [Savezna komisija za međunarodne kulturne veze] (559), box No. 122, archival unit 259, Report on the performance of the mixed folk dance group in Llangollen 1953.
} 
from the time of the Kingdom of Yugoslavia or WWII. What was their encounter with Western Europe like? Did they fall under the spell of the world on the other side of the Iron Curtain, or did they just see confirmation that the construction of socialism was the only right path they should follow? We have an example at our disposal of how individuals fell under the spell of the capitalist world.

The Oro Folk Dance Ensemble of the People's Republic of Montenegro spent the summer of 1954 touring France. The tour was almost a routine: performances, applauses, favorable reviews, journey by train from one place to another. However, it was noted that the members of Oro were less interested in the cultural monuments of the places they were visiting going to stores. That is, until the moment when a group of "six brazen men" from the ensemble were caught shoplifting at a watchmaker's shop in Saint-Nazaire. A scandal erupted and local newspapers wrote about it immediately. The perpetrators were apprehended, but the Yugoslav Embassy made sure they were set free and the entire case was covered up. ${ }^{15}$

And with what program did the three professional ensembles present themselves to foreign audiences? We have seen that Tanec presented Macedonian folk dance in the United Kingdom, which is understandable, because Macedonians were only formally recognized as a nation in 1945, although they have a rich, versatile and attractive folk musical tradition. Around 1950, Kolo's program was as follows: the Banat Dance accompanied by a tambura orchestra, Folk Dances from Montenegro, the Warrior Dance of Rugovo, Folk Dances from the Skopje Region, the Dance from the Island of Krk, Folk Dances from Serbia, the Men's Dance, the Dance from Debar (western Macedonia), the Bunjevac Men's Dance, the Tin Whistle Duet-Serbian Folk Melodies, Folk Dances from Prizren, the Glamoč Dance, Slovene Folk Songs accompanied by the accordion, the Men's Show-Off Dance from Banat, and Folk Dances from Slavonia and Posavina. ${ }^{16}$ The presented program was considerably Yugoslav, and it was based on the conviction that Kolo represented Yugoslavia as a whole, not just Serbia as its republic of origin and the Serbian people. Up until then, Lado, depending on the circumstances, performed three programs, each with a different character. The first program aimed at being purely Croatian: the Ladar Folk Song from central Croatia, the Istrian folk song The Vine Bore Fruit, and the Balun Dance, the Slavonia Dance with tambura, Two Bosnian Folk Songs, the Dance from the Island of Krk, the Vrlika Dance, St. George's Day Folk Song from Brezovica, the Bunjevac Men's Dance, the Slavonia Harvest Song, Two Dances from Pokupsko, the Slavonia Men's Folk Song, the Dalmatian dance and song Lindo, and Posavina Dances. The second and third programs had a more generally Yugoslav character. Along with the aforementioned Croatian dances and songs, they included

${ }^{15}$ AJ, 559-122-260, Report from the tour of the Oro Folk Dance Ensemble of the People's Republic of Montenegro in France from August 4 to September 6, 1954, October 15, 1954, Cetinje.

16 AJ, 559-122-259, The program of the Kolo ensemble on tours 1950-1952. 
Macedonian folk dances (the Bride's Dance, the Tinsmith's Dance, the Women's Dance and the Running Dance), the Bosnian Women's Folk Song and Dance, Two Slovene Folk Songs and the Serbian dances Moravac and Čačak. ${ }^{17}$

Who is encouraging chauvinism

and who is adhering to the so-called socialist relations?

When the three professional ensembles were not yet well-known on the international scene and the Western European audience was just getting to know Yugoslav musical folklore, Lado, Tanec and Kolo cooperated and went on tours together as mixed groups. International recognition followed: victories in Llangollen and invitations from various managers to go on new and attractive tours. Earnings from concerts were becoming an increasingly important issue when arranging tours. The three ensembles started to feel as though they were competing with each other, and sometimes they would perform in the same countries and cities at almost the same time. It was noticeable that part of the Western European audience was inundated by Yugoslav folk dance, while in certain countries "where political reasons require closer cultural ties" none of the three ensembles performed. Ultimately, all three professional ensembles perceived tours of amateur ensembles as a disturbance because, according to Kolo director Olga Skovran, they copied the program of the professional ones, but performed it at an artistically lower level. This damaged the reputation and undermined the price of professional ensembles. ${ }^{18}$

At the beginning of 1956, a serious conflict erupted between Kolo and Lado because of an appealing tour in the Federal Republic of Germany. Both ensembles wanted the tour and the earnings for themselves, so they hired local managers who fought for their clients quite unscrupulously. The situation that ensued encouraged Lado director Ivo Kirigin to write a lengthy letter to the authorities in which he complained about the attitude of the state toward his ensemble. He accused Jugokoncert and its director Veljko Bijedić of systematically neglecting the Croatian ensemble, whereas the other two ensembles had the support of the authorities. $\mathrm{He}$ even listed several examples. In late 1954, Jugokoncert conducted negotiations on Lado's tour in the US and Canada and Kolo's tour in Latin America. However, allegedly with no explanation, the Commission for International Cultural Links gave the North American tour to Kolo. According to Kirigin, Jugokoncert faked negotiations with a Bulgarian concert agency on Lado's tour in Bulgaria, only for Tanec to go on the tour in the end (October-December 1955). Lado prepared for a tour in Palermo in February 1956, but for reasons unknown, was not granted

17 AJ, 559-122-259, The program of the Lado ensemble on tours 1950-1952.

18 AJ, 559-122-260, Note from the meeting at the Commission for International Cultural Links with the representatives of Jugokoncert and state folk dance ensembles, March 7, 1953. 
the Italian visas. It just so happened that, at roughly the same time, the Ivo Lola Ribar ensemble performed in Palermo. "We can't help but get the impression that someone from the Yugoslav side is directly or indirectly to blame that Lado didn't get to perform in Italy."

Kirigin also found it disputable that Kolo had a lavish brochure, whereas there were allegedly no funds to print even a regular one for Lado. He complained about the words used in Tanec's brochure, which said: "sponsored by the Macedonian state, in cooperation with the Yugoslav Government," and about a short text from newspaper Borba, which Jugokoncert had attached with the propaganda material for the Macedonian ensemble. It supposedly said that Tanec had surpassed the other two state ensembles with its performance in Ljubljana. He claimed that this was why foreign managers were neglecting Lado. Kirigin concludes the letter, which is reminiscent of entries in a complaints book of a hotel, stressing that the attitude of "the authorities' side" encouraged chauvinistic interpretations in the Croatian public. He believed that this was due to someone's petty individual interests. However, he did place himself in the role of a defender of the so-called socialist relations. ${ }^{19}$

A similar letter was written in 1966 by Branko Bekić, who took over as Kolo director after Olga Skovran retired. He claimed that his ensemble had not had the financial or moral support of the Federal Commission for International Cultural Links for seven years (1960-1966). Allegedly, the state neglected the best Yugoslav professional folk dance ensemble (one brochure from that period literally says: Kolo: Leading Folklore Group of Yugoslavia), and favored not just the other two professional ensembles, but also certain amateur ones. Furthermore, he claimed that there had been cases where certain foreign countries requested Kolo to perform, but the state sent a different ensemble. ${ }^{20}$

Dušan Vejnović, assistant to the president of the Federal Commission for International Cultural Links, ${ }^{21}$ answered Bekić's letter. The Commission assisted financially the tours of folk dance ensembles before as a medium Yugoslavia's political propaganda. However, performances of folk dance ensembles abroad had become so frequent and the ensembles themselves so wanted that it concluded there was no need to allocate funds to large ensembles which had established cooperation with foreign managers and were arranging tours on their own. Vejnović explained that the Federal Commission had limited itself to helping where "political needs so require." That is why the Commission bore the costs of the tour of the Kočo

\footnotetext{
${ }^{19}$ AJ, 559-126-267, Letter by Ivo Kirigin, The relations of the Lado ensemble with other ensembles and Jugokoncert, March 14, 1956.

${ }^{20}$ AJ, 559-125-266, Kolo director Branko Bekić on the claims that it is favored over other ensembles, June 27, 1966.

${ }^{21}$ In 1965, the Commission for International Cultural Links was reorganized, and the adjective "federal" was added to the name.
} 
Racin ensemble from Skopje in Bursa, because it recognized the political need of a more intense cultural exchange between Yugoslavia and Turkey. The Turks requested Tanec, and Tanec turned to the Federal Commission with a request for funds for that purpose. However, the Commission rejected Tanec, choosing the lesser-known, but still high-quality amateur ensemble. Vejnović concluded that the Federal Commission would not finance the tours of folk dance ensembles, "except where the Federation is exceptionally interested." 22

\section{Kolo vs. Turist-Express-Lado vs. the United American Croats}

Well-known American manager Sol Hurok took notice of Yugoslav musical folklore during the first tours of the three professional ensembles and offered in 1952 to organize Kolo's tour in the US and Canada. The estimated costs of one such tour were enormous, and since he was not willing to pay for the transport across the Atlantic Ocean, negotiations stopped. Two years later, when an offer of a smaller manager arrived, the Belgrade-based company Turist-Express got involved in the negotiations and offered to organize the tour in an attempt to break into the American market. Hurok returned to the game and after long negotiations, Kolo went on a three-month North American tour at the end of 1956. The success of the ensemble was great: according to the report by Olga Skovran, the ensemble traveled about 43,000 kilometers and held 56 concerts in 43 American and Canadian cities. However, the success of the tour was overshadowed by a fierce clash between Kolo and Turist-Express. And what was the clash about? Money, of course. As the representative of Kolo, Turist-Express concluded an agreement with Hurok, which involved covering the costs of the ensemble's participation in a TV show and paying the daily wages of all the members of the ensemble for all 13 weeks of the tour. Just before they went on the tour, it turned out that the TV show would not be recorded "for political reasons," which meant that this would not be a cost. Therefore, Kolo decided to take four other much needed members of the ensemble on the tour, presuming that the issue of their daily wages would be solved on the fly. During the ensemble's stay in the US, Hurok decided to cut the tour down from 13 to 11 weeks due to Christmas holidays, and he agreed that the amount earmarked for the daily wages would remain the same. This opened the possibility of paying the daily wages of the four men who had been included in the tour just before the start. However, Turist-Express, which managed the money for the entire project, refused to do so. A dispute ensued in which Kolo members "fought only for [...] the rights of the working man to be paid legally for his work," and not be "a means of achieving [someone's] profit," but there was no result. Turist-Express kept the

\footnotetext{
22 AJ, 559-125-266, Assistant to the president of the Federal Commission for International Cultural Links Dušan Vejnović to Kolo director Branko Bekić, September 29, 1966.
} 
money, and upon their return to Belgrade, the members of the ensemble who had been paid shared their earnings with the colleagues who had not. ${ }^{23}$ Sources do not reveal what happened next, nor whether the case went to court.

The Lado ensemble had a completely different experience in the US, and its tour was directed mostly toward Croat expatriates in America. According to the Zagreb-based Croatian Heritage Foundation, Croatian expatriates in the United States were dissatisfied because folk dance ensembles from Croatia did not tour in their towns. The Foundation tried to explain the reasons for that to the expatriates and wrote a letter for their newsletter Zajedničar. In the letter, it stated that Lado was a professional ensemble, and thus arranged its tours independently, with the mediation of local managers. Since Hurok's agency sustained a loss when Kolo toured the US, it refused to fund the Croatian ensemble. On the other hand, the choir of the Branko Krsmanović Academic Cultural Artistic Society from Belgrade performed in the US twice in a short period of time because its manager made a profit off its first appearance and decided to try it again. A rich expatriate from Pittsburgh tried to help Lado, but negotiations fell through because the ensemble wanted members to be paid daily wages, which the man could not secure. ${ }^{24}$

The tour was, nonetheless, held in 1967. It lasted for three weeks and covered Los Angeles and New York. The concerts earned "the admiration of the lovers and connoisseurs of folk dance," but the financial effect was quite poor. Lado performed on an open stage in cold autumn conditions, which affected the performers' health, as well as the attendance. Croatian expatriates, who had originally openly expressed their dissatisfaction with the fact that their homeland had not sent Croatian ensembles, did not show enough interest to attend the concerts. Ultimately, the concerts also ostensibly felt the boycott of the US audience resulting from the stance of the SFRY toward the Middle East-Yugoslavia supported the Arab coalition in the Six-Day War and severed diplomatic ties with Israel. This boycott was particularly prominent in New York, where the Jewish population is substantial.

Ustasha emigrants tried to use Lado's tour for their own propaganda. The association the United American Croats from New York handed out a leaflet with a drawn map of Croatia, which included the entire territory of the Socialist Republic of Croatia and the Socialist Republic of Bosnia and Herzegovina, Srem, Bačka and the Montenegrin seaside, with an apt text saying that Croatian folk dance showed that Croats were a special nation with great tradition. Therefore, it was only natural that Croats sought the right to self-determination, which had been proclaimed by US President Woodrow Wilson half a century earlier and confirmed by the Atlantic Charter of the United Nations. The Croatian nation had all the essential

${ }^{23}$ AJ, 559-125-266, Statement of Kolo director Olga Skovran regarding the dispute with the company Turist-Express on the tour in America, January 14, 1957, Belgrade.

${ }^{24}$ AJ, 559-126-267, Letter of the Croatian Heritage Foundation, January 24, 1966. 
preconditions to build an independent state: a long history, a rich and diverse culture, and an industrial base for swift economic development. The conclusion of the leaflet pleased the American ear-the United American Croats were asking for a national state in which democracy and social justice would prevail. ${ }^{25}$

During the tour, several members of the ensemble inquired about the possibility of remaining in the US, and one of them asked for political asylum and remained there. Allegedly, he had prepared for this even before embarking on the tour. ${ }^{26}$

\section{From the Kremlin to the imperial palace in Beijing}

The mending of relations between Yugoslavia and the USSR after Stalin's death and the meetings between Josip Broz Tito and Nikita Khrushchev in May and June 1955 was reflected in tours of Yugoslav professional folk dance ensembles. ${ }^{27}$ Kolo spent almost four and a half months (August-November 1955) on tour in two of the world's leading socialist countries, the USSR and the People's Republic of China, while it also visited Burma, which continued to play a significant role in Yugoslavia's foreign policy at a time when the future non-alignment policy started taking shape.

The first part of the tour was held in the USSR. In Moscow, Leningrad, Kiev and Riga, Kolo held a total of large-scale 20 concerts. Most of the shows were held on large summer stages-in Riga, Kolo performed in front of 30,000 people, while in Moscow, it performed in front of 12,000 people. The ensemble performed at the Bolshoi Theatre in front of high representatives of the Soviet Communist Party, which also included Vyacheslav Molotov and Anastas Mikoyan as the most prominent spectators. Outside of grand stages, Kolo also performed in certain factories. Its director Skovran underscored the cordial reception and the services of the host, as well as the enthusiasm shown by the audience. ${ }^{28}$

From the USSR, Kolo went to China. In an effort to mark the sixth anniversary of winning in the revolution and establishing the Republic, the Government of the People's Republic of China invited various cultural delegations and ensembles as guests throughout 1955 . The ensembles that were invited included, among others, the Beryozka dance troupe from the USSR, the ensemble of the Polish People's Army, the ensemble of the Albanian Army, ensembles from Japan, Burma, Vietnam, India, Korea, Mongolia, etc. The Chinese government spared no expense

\footnotetext{
25 AJ, 559-126-267, Leaflet "Croatian National Folklore" by the United American Croats association. ${ }^{26}$ AJ, 559-126-267, The final report from the tour of the Lado ensemble to the US, November 18, 1967. 27 On the normalization of relations between Yugoslavia and the USSR, see Dragan Bogetić, Nova strategija jugoslovenske spoljne politike 1956-1961 [The new strategy of Yugoslav foreign policy 1956-1961] (Belgrade: Institut za savremenu istoriju, 2006).

${ }^{28}$ AJ, 559-125-266, Report by Olga Skovran on Kolo's tour in the USSR, China and Burma, February 6, 1956.
} 
in promoting itself: it paid for the trip to the Chinese border and back for most of the ensembles, and offered them to stay in the country for as long as they liked. That is how the ensemble of the Bulgarian Army spent six months in China, and it even had a special train at its disposal.

According to FPRY Ambassador Vladimir Popović, the Chinese government had the intention of giving Kolo's tour an almost exclusively political character, presenting the ensemble's presence as a return of Yugoslavia to the "side of peace and democracy led by the USSR." However, the Yugoslav side did not accept that, and wanted to reduce the tour to the level of a simple cultural exchange.

The ensemble received a warm welcome in Beijing. Various state officials, representatives of the cultural and public life, members of the Chinese state folk dance ensemble and numerous citizens attended the event. A festive dinner was organized for the guests, and Vice President of the Republic Zhou Enlai received the ensemble the following day. Three concerts were held in China's capital, and the audience rewarded each with warm applause. However, as Ambassador Popović noted, considering that the representatives of the Chinese Communist Party and the state administration were present in the audience, the applause was directed mostly at the political speeches, rather than the artistic program.

From Beijing, Kolo headed to the provinces. It performed a number of shows in Shanghai, Hangzhou, Shenyang and Anshan. The Chinese were quite hospitable toward Yugoslavs. The members of the ensemble were put in the best hotels and provided with special food. Their management had a car at their disposal in every place, and the ensemble traveled through the country by a special train. All members of the ensemble received monetary compensation and gifts, and when they left China, the hosts exchanged their remaining yuans to dollars. Kolo attended the performances of Chinese ensembles, and it gave special performances at certain factories and schools. A domestic film crew followed the ensemble and made a documentary about it. Ambassador Popović claimed that he did not have the slightest idea of how much this tour cost the Chinese (it was evident that they spared no expense, taking into consideration the political benefit of this tour). Because of the special treatment of the ensemble, the FPRY Embassy organized a reception for 500 guests from the political, public and art echelons of China. Even the Vice President of the Republic, Zhou Enlai, attended the reception.

Kolo spent two months in China. It put on 22 shows, which were, according to Popović, attended by around 190,000 people. The Chinese press wrote about the ensemble and Yugoslavia extensively in that time. The audience watched the shows with enthusiasm, often requesting an encore. Once, the members of Kolo paid the hosts back for their generosity by singing a few appropriate songs about Mao Zedong in Chinese, which won further appreciation from the audience. The Ambassador commended the behavior of the ensemble, which "left quite a good impression on 
all the Chinese people with whom they came into contact with their nice, friendly, free personal stance and behavior, and their correct political response." 29

Kolo members were clearly well prepared and trained on how to behave in politically delicate situations like their tour in the USSR and China, i.e. countries whose party bureaucracies were not willing to accept Yugoslavia's independent path to socialism. However, according to Skovran, during the tour, they traveled 50,000 kilometers and spent 45 days on a train, while also handling the hot and humid monsoon climate of Burma. Naturally, this led to weakened discipline and certain incidents. The details are unknown, but the director of the ensemble was particularly dissatisfied with the behavior of a Radio Belgrade reporter, who allegedly interfered with her work on several occasions. ${ }^{30}$

The Branko Krsmanović Song and Dance Ensemble followed in Kolo's footsteps. They went to China in November and December 1957. Representatives of the Yugoslav and Chinese youth arranged the tour, and it was agreed that the Chinese government would bear the costs of the transport of people and equipment via airplane to China and back, as well as all the costs incurred in the country. The management of the ensemble defined the character of the tour before their departure. Through concerts, they were meant to present the results of the building of socialism in Yugoslavia and show how the academic youth was contributing to the progress of its socialist homeland. The ensemble was greeted in Beijing by representatives of Chinese youth and student organizations, who took good care of it throughout the tour. Between performances, members of the ensemble were taken to organized visits to universities, factories and various cultural establishments. They even had the chance to admire the famous Great Wall of China. ${ }^{31}$

\section{The warrior dance of Rugovo "against" the Cossacks}

When we look at the tours of Yugoslav folk dance ensembles abroad, it is evident that they were far more frequent in Western countries or non-aligned countries than in the countries of the Warsaw Pact. The exchange of ensembles between the Yugoslavia and Bulgaria was present to a certain extent, while tours in the USSR were rare, which was largely a result of the ups and downs in the relations between the two countries with diverging views on how to build socialism. After the reconciliation initiated by Nikita Khrushchev in 1955, which brought about

${ }^{29}$ AJ, 559-125-266, Classified report by FPRY Ambassador to China Vladimir Popović, November $10,1955$.

${ }^{30}$ AJ, 559-125-266, Report by Olga Skovran on Kolo's tour in the USSR, China and Burma, February 6, 1956 .

${ }^{31}$ AJ, 559-126-269, Report on the tour of the Branko Krsmanović Song and Dance Ensemble in China, April 10, 1958. 
the aforementioned tour of Kolo that same year, and after a few years of good relations and cooperation, a new chill followed, caused by the Soviet intervention in Czechoslovakia in August 1968.

The tour of the Shota Folk Dance Ensemble of Kosovo in the Ukrainian Soviet Socialist Republic in July 1971 can be viewed as an expression of a new improvement in relations. The tour was realized based on the stipulations of the SFRY-USSR Cultural Cooperation Program. According to the report, Shota was the first Yugoslav folk dance ensemble that performed in Ukraine. The troupe performed in western Ukrainian cities of Mukachevo, Chernivtsi, Vinnytsia, Kamianets-Podilskyi, Khmelnytskyi, Ternopil and in Kiev. The program encompassed folk dances of different ethnic groups from the Kosovo and Metohija region, including: the Warrior Dance of Rugovo, the Albanian Dance, Albanian Dances from Gjakova, the Albanian dance Shota, Albanian dances from Metohija Dukagjini, Albanian Folk Songs, Serbian Kosovar Folk Songs, the Folk Dance Suite from Serbia, Old City Songs and Dances from Prizren, Montenegrin Songs and Dances, Turkish Songs and Dances and Gipsy Songs and Dances. ${ }^{32}$

\section{From Port Said to Casablanca}

Ever since the dissolution of the Ottoman Empire, the Middle East has been a region of latent conflicts and the intertwining of local interests with the interests of great forces. After Jewish settlers to Palestine declared the state of Israel in 1948, that area became the center of a series of wars between the Jewish state and the surrounding Arab states, as well as protracted civil wars, such as the one in Lebanon in the 1970s and 1980s. Yugoslavia was one of the first states to recognize Israel and establish diplomatic relations with the country. However, out of all the states in the Middle East, Yugoslavia had the closest cooperation with Egypt, especially after the king was dethroned and the republic established in 1952. ${ }^{33}$ Since then, Yugoslav universities received numerous Egyptian scholarship holders, large companies organized internships for numerous Egyptian engineers and qualified workers, and Yugoslav experts of various profiles were hired in the Egyptian economy, healthcare and education. ${ }^{34}$

Yugoslav folk dance ensembles actively participated in the cultural cooperation and exchange with Egypt. In January 1958, Lado toured Cairo, Alexandria, Ismailia and some other smaller towns in the Nile Delta. It held 30 concerts and,

\footnotetext{
32 AJ, 559-125-265, Report on the tour of the Shota Folk Dance Ensemble of Kosovo in the USSR, September 6, 1971.

33 Bogetić, Nova strategija, 165-168; Aleksandar Životić, "Jugoslavija i Bliski Istok (1945-1956) [Yugoslavia and the Middle East (1945-1956)]," in Spoljna politika Jugoslavije 1950-1961, 483-496. ${ }^{34}$ AJ, 559-209-430, Scholarship holders and residents from the United Arab Republic; AJ, Bureau for International Technical Cooperation [Zavod za međunarodnu tehničku saradnju] (208), records currently being processed.
} 
according to the report of the Yugoslav Information Centre in Cairo, the success of Lado was all the greater, considering that the Egyptian scene had been inundated by the performances of folk dance ensembles from the Warsaw Pact for the previous few years, and that their respective states had covered most of the expenses.

The tour in Egypt was based on commercial grounds, without the financial participation of the two states. Lado hired a local manager, who owned a night club. As such, he was not fit for the job and nearly went bankrupt. He could not, or would not, print the program of the performance, he was not sure whether he would be able to secure the hall of the Cairo Opera House as the most representative one in the country and, once he realized he was facing bankruptcy, he refused to pay for the ensemble's return to Yugoslavia, although this was included in the contract. So, the members of Lado were not certain for a few days when and how they would return home. FPRY Ambassador Josip Đerđa intervened, securing the money and taking care of the organization of the tour.

Despite these problems, the tour was a success in terms of political propaganda. Reportedly, the enthusiasm the audience with the performances of the troupe turned into a "true manifestation dedicated to Yugoslavia." In this regard, the report on the tour particularly stresses the success achieved among Egyptian workers in the industrial center Mahalla. However, there is one detail that the Egyptian public did not particularly like: at that same time, Kolo toured Israel and the Yugoslav media covered that tour more than Lado's tour in Egypt. ${ }^{35}$

The success of Lado paved the way for other Yugoslav ensembles. At the beginning of 1964, the Ivo Lola Ribar troupe performed in Egypt as part of an international folklore festival. Lola's score in the competition was below what had been expected, but the work of the ensemble once the festival was over was more important for Yugoslavia's foreign policy than the outcome of the competition itself. The ensemble held a series of concerts in Alexandria, Port Said, Aswan and some smaller places. It performed at several youth camps, sports centers and factories, presenting its abridged program; it performed for the Yugoslav Embassy staff and members of the Yugoslav People's Army on a UN peacekeeping mission on Mount Sinai. The host tried to be accommodating to the Yugoslavs in every way. During the festival, Lola and the other ensembles were placed in luxury hotels and ate first-class food. In the second part of the tour, the accommodation and food were significantly less luxurious, but the hosts remained cordial and accommodating, which the members of Lola appreciated greatly. ${ }^{36}$

The Maghreb was another region that had been in the focus of Yugoslav foreign policy since the mid-1950s. The Yugoslav government actively helped

\footnotetext{
35 AJ, 559-126-267, Report of the Yugoslav Information Centre in Cairo, February 10, 1958. ${ }^{36}$ AJ, 559-126-270, Report on the tour of ACAS Lola in Egypt, April 2, 1964, Belgrade.
} 
Tunisia and Morocco in the first years after they gained independence from France, as well as the armed fight of Algerians against French occupation. ${ }^{37}$

A fundamental part of Yugoslav diplomacy directed toward the Maghreb was Kolo's tour in Morocco and Tunisia at the beginning of 1959. The ensemble performed 19 concerts in Casablanca, Rabat, Fez, Marrakesh and Tangier, and 7 concerts in the city of Tunis. The program was versatile, encompassing folk dances from all parts of Yugoslavia. According to Olga Skovran, the tour was successful from the artistic point of view, but attendance was low. The tickets for the shows were too expensive for the average citizens of Morocco and Tunisia. The Italian tour manager's reasoning for the price was that the organization costs were excessively high. Therefore, to the obvious disappointment of the director of the ensemble, members of the French community were prevalent in the audience in these countries. However, not even they attended the concerts as expected: many boycotted them due to Yugoslavia's active participation in the Algerian War of Independence. That is why the Kolo director proposed that the Yugoslav state subsidize future tours in poor, newly liberated countries, so that professional ensembles would not have to charge the full price of tickets (which was mostly in the interest of managers). The political propaganda effect of the tour was most important, even at the cost of lower earnings. ${ }^{38}$

\section{A herald of economic delegations}

The tour of the Ivo Lola Ribar ensemble in India and Afghanistan in February and March 1967 differs from the tours presented above because its main goal was not ideological or political, that is, its goal was not typical propaganda about Yugoslav culture. Instead, it was expected that it would encourage economic cooperation of Yugoslavia especially with India, but also with other countries through which the ensemble passed. That is why the tour received not only the usual funding from the Federal Commission for International Cultural Links, but also from the India division of the Yugoslav Chamber of Commerce, the Ivan Milutinović company from Belgrade, which specialized in building ports and similar structures on water, and foreign trade company Intertrade from Ljubljana.

From Belgrade to Bombay, the ensemble crossed thousands of kilometers by train and plane, traveling through Bulgaria, Greece, Turkey, Lebanon, Syria, Iraq, Iran and Afghanistan. It performed a total of 40 concerts (10 were held in Afghanistan and 19 in India). During the two-hour program, only six dancing couples performed dances from different regions of Yugoslavia (the program was more or less copied from Kolo, with the Warrior Dance of Rugovo and the Glamoč

37 Srđan Miletić, "Jugoslavija i zemlje Magreba 1956-1958 [Yugoslavia and the Maghreb countries 1956-1958]," in Spoljna politika Jugoslavije 1950-1961, 497-512.

38 AJ, 559-125-266, Report by Olga Skovran on Kolo’s tour in Morocco and Tunisia, March 10, 1959. 
Dance as the main hits). Members of the ensemble had to get used to drastic climate changes in quite short amounts of time. They performed for several days in Kabul, at an altitude of over 1,500 meters, only to fly to the seaside city of Bombay, where they were greeted by a temperature of 30 degrees Celsius and high humidity. The government of Afghanistan paid great attention to its guests because they were the first Yugoslav performing artists to visit the country. The prime minister, together with several ministers and two members of the royal family, watched the performances in Kabul. In India, heads of cabinets and general secretaries of the Ministry of Foreign Affairs and other important ministries attended the concerts.

In the report on the tour, the management of the ensemble stressed the significance of cultural exchange "for the introduction of a more direct and cordial atmosphere in economic and business relations between the countries." It was for those reasons that Lola extended its stay in India for another week, performing for Indian workers at various factories. The extension was paid by Indian companies and the Yugoslav Consulate General in Bombay. With regard to these additional concerts, special pamphlets were printed with information about Yugoslav companies and other business information. ${ }^{39}$

\section{The Rashomon effect in Santiago de Chile}

Latin America was the subject of interest of Yugoslav diplomacy already before WWII, mostly due to the large diaspora of Yugoslav, predominantly Croatian, expatriates in Argentina, Chile and Uruguay, but also due to the aspiration to establish economic cooperation with these countries. ${ }^{40}$ In the beginning, socialist Yugoslavia was also mainly interested in its expatriates, ${ }^{41}$ but as of the late 1950 s, the continent also became important due to the expansion of the Non-Aligned Movement. ${ }^{42}$

Since musical folklore proved to be a successful instrument of Yugoslav diplomacy, a meeting was held between the representatives of the State Secretariat for Foreign Affairs, the Commission for International Cultural Links and Jugokoncert at the beginning of 1959. They discussed sending one of the three professional

\footnotetext{
${ }^{39}$ AJ, 559-126-270, Report of the leaders of the journey of the Folk Dance and Song Ensemble Lola across Asian countries (with special addenda), April 1967, Belgrade.

${ }^{40}$ Predrag Krejić, "Priznanje Kraljevine Srba, Hrvata i Slovenaca od strane država Južne i Centralne Amerike [The acknowledgement of the Kingdom of Serbs, Croats and Slovenes by the states of South and Central America]," Arhiv 1-2 (2006): 81-91.

${ }^{41}$ AJ, The FPRY Government's Committee for Schools and Science [Komitet za obrazovanje i nauku vlade FNRJ] (315), box No. 3, archival unit 10, Minority schools of the FPRY abroad; AJ, 315-27-63, Yugoslav minority schools in Chile.

42 Vidosava Eraković, “Titova 'američka turneja' 1963. godine - poseta Brazilu, Čileu, Boliviji, Peruu i Sjedinjenim Američkim Državama [Tito's “American tour” in 1963-visit to Brasil, Chile, Bolivia, Peru and the US]," Arhiv 1-2 (2015): 168-181.
} 
ensembles on a long tour in Latin America. All three ensembles were interested, but the considerable travel expenses for 45 passengers and about 1,500 kilograms of luggage presented a problem. Lado was selected and the spring of 1960 was suggested for a three-month tour. The ensemble would have six evening shows and one matinee a week. The Commission for International Cultural Links and Jugokoncert would bear the travel expenses from Yugoslavia to Latin America, while local managers would cover all the costs in Latin American countries. It was decided that the tour would encompass Brazil, Argentina, Uruguay, Chile and possibly Venezuela. The first show would be held in Rio de Janeiro on April 2, 1960. It was decided that the earnings from the performances would be used to cover the expenses of their return, and what was left would become pocket money. ${ }^{43}$

A plan may seem feasible when discussed in an office, but reality usually requires adaptation. The management of Lado wanted to take over the organization of the tour itself. It contacted the country's biggest shipping company Jugolinija, and this was the response: the journey by cargo ship would last 22-30 days in one direction and would depend on the number of ports where the ship would have to dock to load and unload goods. Therefore, the starting date of the tour could not be specified. Apart from that, a long journey on a ship with insufficient movement would affect the fitness level of the dancers. Ultimately, it turned out that Jugolinija did not even have a ship with more than 12 beds, nor did it have the option of adding the necessary beds for the 45 passengers that were to go on the tour. They considered traveling by a foreign ship. There was even a Genoa-Buenos Aires line, which took 14-15 days, but it was much more expensive than Jugolinija. As for the option of flying: the Putnik agency could secure an aircraft from Zagreb to Buenos Aires, but it wanted to be paid in dollars, because JAT Airways had to cover the expenses of fuel and the stay of the flight crew abroad. ${ }^{44}$

In the months that followed, the problems regarding the organization of the tour grew so much that it was becoming uncertain whether it would take place at all. In early May 1960, Laza Jakšić of Jugokoncert went to Santiago de Chile to arrange the details with local concert agencies. He was one of the people included in the aforementioned letter by Ivo Kirigin from 1956. This meant that the latent conflict between Lado and Jugokoncert over the alleged neglect of the Croatian ensemble spread to Latin America.

According to Yugoslav Ambassador to Chile Ljuba Faust, Jakšić came to Santiago unprepared, without any knowledge of foreign languages (allegedly, he knew some German). On the way, he tried to carry out what he said was an order

\footnotetext{
${ }^{43}$ AJ, 559-126-267, The meeting of the representatives of the SSFA, CICL and Jugokoncert regarding the tour of a folk dance ensemble in Latin America, January 30, 1959.

${ }^{44}$ AJ, 559-126-267, Recapitulation of the travel expenses of the Lado ensemble for South America, 1960 .
} 
from Belgrade to include Cuba and Venezuela in Lado's schedule, which was politically desirable but difficult to achieve due to the distance of the countries from Chile and the high costs. Supposedly, he behaved quite unprofessionally during the negotiations with the Chilean manager. He put the embassy in an unpleasant position, because he had not brought enough money with him, thus disgracing the country. "At the hotel where he stayed, Jakšić begged them to lower the prices, and once they did, he allegedly could not pay even that significantly reduced price." 45

The report by Jakšić paints a different picture of these events. Before going on the journey, he went to Zagreb to consult with the management of the ensemble. After a three-day journey, he was greeted at the Santiago de Chile airport by a reputable expatriate Danilo Matulić, who worked part-time at the Yugoslav Embassy. Matulić placed him in the best hotel, whose co-owner was an expatriate from Zagreb. The very next day, Ambassador Faust received Jakšić and initiated the conversation cordially, remembering him as an actor in the $\mathrm{ZAVNOH}$ theatre during the war, but changed his tone immediately and cut to the chase: the Embassy refused to cooperate with Jugokoncert because of numerous misunderstandings in their previous cooperation. Moreover, he considered the arrival of the representative of the agency undesirable. Nonetheless, Jakšić asked to be put in touch with the local manager Merlet, recommended by the Embassy. Faust asked Jakšić, most likely in a raised voice, whether he knew Spanish. Since he said he did not, Faust referred him to the aforementioned expatriate Matulić, adding that Jakšić himself should take care of paying for his services. When Jakšić responded that he had started his journey across the ocean with only 200 dollars, which was the amount Belgrade had approved, the ambassador was flabbergasted. He said that this was highly unprofessional and that he "wanted nothing to do with the whole thing," wishing Jakšić good luck in his further work. "This first reception at the Embassy looked like a genuine burial of the III order."

Matulić accepted the role of mediator and Jakšić met with Merlet soon. Jakšić, who invoked his many years of managerial experience, concluded that the Chilean was a dilettante "without a penny to his name," with no experience or specific profession. Jakšićs doubt in Merlet was supported by the case of the London Festival Ballet. The Ballet had performed in Santiago a while back and had been left without its earnings from the performance because the local manager ran away with the entire amount of $\$ 12,000$. The question that arose was how such a man had been entrusted with the complex activities of organizing the tour? Merlet was supposedly a friend of a ballet master from Santiago, who had seen Lado perform two years earlier in Zagreb, which gave him the idea to earn some money by organizing the tour. To do that, he made a deal with Capdevilla from Buenos Aires, who was known as a collector of theatre program ads and could organize the tour along the Atlantic

\footnotetext{
${ }^{45}$ AJ, 559-126-267, Report of FPRY Ambassador to Santiago de Chile Ljuba Faust on the meeting with Jugokoncert's representative Laza Jakšić, May 24, 1960.
} 
coast, while Merlet would cover the Pacific coast. Jakšić turned to the aforementioned ballet master for advice. The man was surprised that the Yugoslav side put their trust in Merlet, who did not have a particularly good reputation in Santiago, and Jakšić responded that the Yugoslav Embassy had recommended him. We can only imagine how confused Jakšić must have been, when he once again turned to Ambassador Faust, only to see Faust react strongly to the remark that Merlet had been chosen following his advice. Faust said he was washing his hands of everything and that Jakšić should not count on the Embassy's help. Jakšićs mission thus failed and Lado's tour was postponed. In the conclusion of the report, Jakšić puts part of the responsibility for the failure of negotiations on the Branko Krsmanović folk dance ensemble, which performed the act of unfair competition, visiting Mexico and Venezuela at the same time. Allegedly, members of the Krsmanović ensemble spread rumors that their ensemble was the best and that Lado was bad, which supports the aforementioned allegations of the director of the Croatian ensemble. ${ }^{46}$

Lado's tour in Latin American countries was still held, but only in late 1962. The troupe went on the tour abruptly, because the Commission for International Cultural Links requested that the money allocated for the tour be spent by the end of the year, or returned to the budget. The tour included Chile, Argentina, Uruguay and Brazil. During the 40 days they spent on the continent, the ensemble held 45 concerts. In fact, 38 concerts had initially been planned, but due to poor attendance and, consequently, low earnings, the members of the ensemble had to push themselves and do extra shows to make sure they were able to pay for the return airplane tickets. Poor organization of the tour, left in the hands of local managers, led to low attendance at the concerts. The date of the tour was also poorly selected because November and December are summer months in the Southern Hemisphere, and it is hot and humid, so the concert season is on a break. ${ }^{47}$

Their tour in Uruguay was deemed a huge missed chance. Organizing the tour in the last minute did not give the Embassy enough time to properly promote it, so Lado performed in half-empty venues. The earnings were slim and the members of the ensemble had to give up their allowance. During one of the concerts, an Ustasha emigrant threw from the gallery a bunch of leaflets protesting "the use of Croatian cultural heritage for Yugoslav and communist purposes." The right-wing newsletter El Dia accused the management of the theatre Solis in Montevideo of enabling communist propaganda in Uruguay. The show in Argentina also fared poorly, without much notice. ${ }^{48}$

\footnotetext{
46 AJ, 559-126-267, Report by Jugokoncert representative Laza Jakšić on the negotiations in Santiago de Chile, 1960, Belgrade.

47 AJ, 559-126-267, Report on Lado's tour in Latin America, February 8, 1963.

48 AJ, 559-126-267, Report on Lado's tour in Uruguay, December 20, 1962.
} 
After performing in Uruguay and Argentina, Lado went on to Chile. The Yugoslav diaspora in the country, mostly consisting of Croats from Dalmatia, took over the financing of the tour. If Merlet, as the choice of the Embassy, proved to be a bad solution, the choice of the expatriates was no better. They hired the owner of a local circus, who did his job quite poorly. Consequently, the earnings from the shows were not particularly good. Despite everything, it was deemed that the political propaganda effect of the tour was significant, among Yugoslav (Croatian) expatriates as well as other Chileans. However, what marked Lado's tour in Chile was a member of the ensemble fleeing and requesting political asylum from the Chilean authorities. His motives are unknown, and it is also unknown whether he had any relatives in Chile or not. We suppose that he, as many other asylum seekers, went on a search for a better life than the one he had in his homeland. ${ }^{49}$

\section{Tanec discovers Africa}

Not many Yugoslavs could boast about going to Africa before 1950. One of the rare people who could, who even left a valuable written testimony of his travels through the French and British territories in Western Africa at the end of 1929, was writer and diplomat Rastko Petrović. ${ }^{50}$ At the end of the 1950s, in line with Yugoslavia's strategic course of presenting itself as the leader of the so-called Non-Aligned Countries-countries that remained outside the division in the two dominant and opposing ideological and political blocks-scholarship holders from newly independent African states or members of liberation movements from territories that remained under the administration of colonial powers started coming to universities and vocational schools in the FPRY. This was the first time most Yugoslav citizens had the chance to meet Africans in person. They did not know much about them, but they often held a prejudiced opinion. Also, many African scholarship holders did not manage to adjust to the Yugoslav environment well, and came into conflict with it. Despite all these obstacles, Africa was becoming increasingly present in Yugoslav everyday life, while Yugoslav experts of various profiles, mostly engineers, qualified artisans and medical workers were also spending more and more time in young African countries, building their infrastructure. ${ }^{51}$

Just like with Lola's tour in India, folk dance played the role of a herald of economic delegations in the case of Tanec's tour in West African countries. The two-month tour took place in early 1968 and was organized by the Federal

\footnotetext{
${ }^{49}$ AJ, 559-126-267, Report of the FPRY Embassy on Lado's tour in Chile, January 8, 1963.

50 Rastko Petrović, Afrika (Novi Sad: Solaris, 2008).

${ }^{51}$ AJ, 559-177-367 Classified records on scholarships and scholarship holders (1951-1962); AJ, 559-177-368, Classified records on scholarships and scholarship holders (1963-1966); AJ, 208, records currently being processed.
} 
Commission for International Cultural Links and the Jugoagent transport company from Belgrade. It included Senegal, Mali, Guinea, Ghana, Congo, and a special concert held in Lagos, Nigeria, which was arranged on the spot. A total of 32 concerts were performed, attended by over 50,000 people, with regular presence of top state officials of every country at the premiere. The core of Tanec's program was Macedonian folk dance, but selected numbers from the folklore of other peoples of Yugoslavia were also performed. ${ }^{52}$ Available sources speak mostly about the shows in Senegal and Guinea, so we will focus on those, naturally.

The Macedonian troupe went to Senegal in February 1968. The Embassy went to great lengths with respect to promoting the performance: a one-hour show about Yugoslav folk dance and about the ensemble was broadcast on national radio and two articles with photographs were published in newspapers with high circulation. The first concert was held on February 5. Several ministers and more than half of the diplomatic corps attended it. The 1,100-seat hall was quite full on the two nights. The response of the audience was positive. The Senegalese particularly enjoyed the melodies and dances in which they could sense the presence of Arabic or even their own motifs. The male part of the ensemble drew more attention of the audience, because the choreography they performed was more striking than the one performed by women. The costumes left a strong impression on the audience. Due to the climate, which the Europeans did not immediately get used to, their voices occasionally sounded weaker. Still, they drew a nice applause, especially a duet of soloists. The piece that left the biggest impression on the hosts was the Shopi Dance, and what left the biggest impression on all Yugoslavs was the gesture of the Senegalese Culture Minister and poet Jean Briere, who wrote a poem dedicated to Tanec.

Several shows for a wide audience were held in the next few days in Dakar and other parts of the country. Performances outside the Senegalese capital were poorly organized, partly due to the mistakes of the hosts and partly due to the limitations of their poverty. In one city, Tanec performed on a basketball court, which was the most that the local authorities could provide. However, at the same time, the authorities made a serious mistake of not providing water to the members of the ensemble until four hours after their arrival. The tour of the Macedonian ensemble in Senegal served as good reason for the Yugoslav Ambassador to once again open the issue of creating a program of cultural cooperation between the two countries, shifting the responsibility to the hosts and the sluggishness of their administration. ${ }^{53}$

\footnotetext{
52 AJ, 559-126-268, Tanec National Ensemble for Folk Dances and Songs of Macedonia - Skopje, Tour in West Africa (from January 30 to March 10, 1968). Program.

53 AJ, 559-126-268, Report of the SFRY Embassy on Tanec's tour in Senegal, February 20, 1968.
} 
From Senegal, Tanec went on to Guinea, where it held five concerts in the capital Conakry and another five in other parts of the country, all in front of large audiences. One of the concert was performed in a place called Kalé, where Yugoslav companies were building a hydropower plant, and another was held at a hospital treating the fighters of the liberation movement from Portuguese Guinea. The ensemble was welcomed well and rose to the occasion everywhere it went. However, the attitude of director Toma Leov toward the hosts cast a certain shadow on the tour. According to the report of the Embassy in Conakry, the hosts complained that Leov was not willing to understand the objective circumstances in which the people of Guinea lived and that he even showed a certain degree of intolerance toward them as Africans. Allegedly, he had unrealistic demands regarding the level of comfort available and did not show respect toward local customs and the attention that the people of Guinea paid him. Even some officials of the Yugoslav Embassy noticed that some of these complaints were founded. ${ }^{54}$

\section{Musical folklore—an instrument of Yugoslav foreign policy}

When in 1949 the top of the Yugoslav Communist Party and the state discussed the need to radically change the country's foreign policy course, this brought up the question of which means to apply in this endeavor. What was it that Yugoslavia could offer to the economically developed West, when its traditionally poorly developed and war-devastated economy was stagnating because of the conflict with the Cominform and the isolation imposed by the USSR and "the people's democracies?" Lacking capital and lacking goods to export, what remained were the products of the culture of its peoples.

After 1949, culture became Yugoslavia's main export product, i.e. the main instrument of its foreign policy. Systematically and in an organized manner, through the Commission for International Cultural Links, diplomatic and consular missions and other state institutions, Yugoslavia marketed its art, which included works from times past, but purified of ideologically undesirable layers, as well as modern ones, all aimed at presenting Yugoslavia as a country building a humane socialist society-completely opposite to the Stalinist one-based on original Marxism and its own revolutionary experience. Musical folklore played a notable role within foreign policy envisaged in such a way, but it would be naïve to conclude that, for example, the Hard One or the Warrior Dance of Rugovo persuaded NATO members to offer aid to the heretic Communist Party and its state. Help from the US came when Washington concluded that the conflict between the two Communist Parties, which had been smoldering practically since the end of WWII, had become irreconcilable and that a serious crack was evident in the

\footnotetext{
${ }^{54}$ AJ, 559-126-268, Report of the SFRY Embassy in Guinea on Tanec's tour, March 19, 1968.
} 
previously firm Communist Bloc. Now, let us imagine a concert of a Yugoslav folk dance troupe in Great Britain, for example, and pick a random spectator and look into their mind. Perhaps they had some ideas about Yugoslavia before; perhaps they knew nothing about the country and its peoples (which does not mean they had no opinion on them, and opinions mixed with a lack of knowledge usually produce prejudice and stereotypes). While watching the concert, they might be mesmerized by the powerful choreography, exotic costumes and the enthusiasm of the young dancers (who were trying to present this enthusiasm as an expression of joy over the construction of the new socialist homeland). If they were a bit more educated, they would search for literature to learn more about the country of the ensemble and its wondrous dances, which could make them develop some affection toward the country. Therefore, the performances of folk dance ensembles in Western countries in the first half of the 1950s had a predominantly political purpose, because they could impact the public opinion, and from there influence the policies of governments toward Yugoslavia in a favorable manner.

The performances in the USSR and "people's democracies," starting from the second half of the 1950s, also had a political purpose. They represented a gesture of goodwill and reconciliation, but they were also a way of proving that the Yugoslav path of socialism was equal to the Soviet or the Chinese one, and that the peoples of Yugoslavia were successfully building this, as it was believed, technologically advanced and just society. So, the performances of the folk dance ensembles and other cultural and artistic societies had the aim of highlighting the independence of the Yugoslav Communist Party (the League of Communists of Yugoslavia as of 1952) and the state from the USSR and the Warsaw Pact, as well as underscoring the unalienable right of a socialist country to choose its own path toward the shared goal of communism.

Performances in Non-Aligned countries had a political and economic dimension. After WWII, the colonial empires of the traditional European forces started falling apart, and new national states started emerging on the vast territories of Asia and Africa. In their first years of formal independence, they were still dependent on former metropolises and wandered, searching for their path. They were facing two conflicting military/political and ideological blocs-NATO and the Warsaw Pact-which were interested in drawing them toward themselves. However, in the mid-1950s an alternative appeared outside the two blocs, which would later grow into the Non-Aligned Movement. The diplomacy of Yugoslavia, led by Josip Broz Tito, which initiated the policy of equidistance-i.e. maneuvering between the two blocs and using their oppositions after the death of Joseph Vissarionovich Stalinsaw an opportunity to tie these newly formed states to itself and present itself as their leader. This is the reason for numerous performances of folk dance troupes and other cultural and artistic groups in Egypt and other countries of the Middle East, 
the Maghreb countries, India, Burma and other countries of the Far East, as well as countries of Sub-Saharan Africa. Part of the funding needed for traveling to these far-away and exotic countries was secured by Yugoslav construction, foreign trade and other companies that hoped to develop lucrative businesses there. Therefore, the Hard One, the Warrior Dance of Rugovo, the Glamoč Dance and other dances were performed to create a good atmosphere before the negotiations of various economic delegations, which would build the infrastructure of many countries in Africa and Asia after the conclusion of favorable contracts.

The performances in Latin American countries were mostly meant for Yugoslav expatriates, who needed to be persuaded of the idea of a socialist and federal Yugoslavia, and separated from the strong propaganda activities of the Ustasha emigrant groups. Of course, Yugoslav diplomacy did not neglect the economic and political aspect of these tours.

The folk dance ensembles themselves recognized their interest in tours, because performances on the international scene would bring in sometimes less, sometimes more money. That is also where the envy and the conflicts between the managements of the three professional ensembles or the misunderstandings with Jugokoncert and the Commission for International Cultural Links originate. When it comes to the ordinary members, the mere fact that they could see the world while performing folk dances meant a lot to them and certain individuals, lured by what they saw (and many of them saw only what suited them), decided to give up on the construction of the socialist country imposed on them and seek political asylum in the country where they toured. 


\section{Primary sources:}

Archives of Yugoslavia (AJ) (Belgrade): Federal Commission for International Cultural Links; The FPRY Government's Council for Science and Culture; The FPRY Government's Committee for Schools and Science; Federal Bureau for International Technical Cooperation

\section{References:}

Bekić, Darko. Jugoslavija u Hladnom ratu. Zagreb: Globus, 1988.

Bogetić, Dragan. Jugoslavija i Zapad 19521955: jugoslovensko približavanje NATO-u. Belgrade: Službeni list SRJ, 2000.

Bogetić, Dragan. Nova strategija jugoslovenske spoljne politike 1956-1961. Belgrade: Institut za savremenu istoriju, 2006. [Orig. in Serbian Cyrillic]

Dimitrijević, Bojan. "Jugoslavija i NATO 1951-1958, skica intenzivnih vojnih odnosa." In Spoljna politika Jugoslavije 1950-1961, zbornik radova, edited by Slobodan Selinić, 255-274. Belgrade: Institut za noviju istoriju Srbije, 2008.

Doknić, Branka, Petrović, Milić F, Hofman, Ivan (Eds.). Kulturna politika Jugoslavije. Zbornik dokumenata II. Belgrade: Arhiv Jugoslavije, 2009. [Orig. in Serbian Cyrillic]

Eraković, Vidosava. "Titova 'američka turneja' 1963. godine - poseta Brazilu, Čileu, Boliviji, Peruu i Sjedinjenim Američkim Državama." Arhiv 1-2 (2015): 167-179. [Orig. in Serbian Cyrillic]

Hofman, Ivan. "Uloga muzičkog folklora u spoljnoj poltici socijalističke Jugoslavije 1950-1952." In Spoljna politika Jugoslavije 1950-1961, zbornik radova, edited by Slobodan Selinić, 437-456. Belgrade: Institut za noviju istoriju Srbije, 2008.

Hofman, Ivan. "Pod stegom Partije. Muzika socijalističkog realizma - primeri SSSR i Jugoslavije." Godišnjak za društvenu istoriju 1-3 (2005): 41-65. [Orig. in Serbian Cyrillic]
Hofman, Ivan. "Savezna komisija za kulturne veze sa inostranstvom 1953-1971 (19461971). Ustanova i njena arhivska građa." Arhivistika: http://www.arhivistika.edu.rs/ clanci/sredivanje-i-obrada-arhivske-grade/.

Krejić, Predrag. "Priznanje Kraljevine Srba, Hrvata i Slovenaca od strane džrava Južne i Centralne Amerike." Arhiv 1-2 (2006): 81-91. [Orig. in Serbian Cyrillic]

Miletić, Srđan. "Jugoslavija i zemlje Magreba 1956-1958." In Spoljna politika Jugoslavije 1950-1961, zbornik radova, edited by Slobodan Selinić, 497-512. Belgrade: Institut za noviju istoriju Srbije, 2008.

Perišić, Miroslav. "Veliki zaokret 1950: Jugoslavija u traganju za vlastitim putem. Kultura - oslonac, prethodnica i sastavni deo spoljne politike." In Pisati istoriju Jugoslavije: viđenje srpskog faktora, edited by Mile Bjelajac, 237-279. Belgrade: Institut za noviju istoriju Srbije, 2007. [Orig. in Serbian Cyrillic] Petrović, Rastko. Afrika. Novi Sad: Solaris, 2008. [Orig. in Serbian Cyrillic]

Životić, Aleksandar. "Jugoslavija i Bliski Istok (1945-1956)." In Spoljna politika Jugoslavije 1950-1961, zbornik radova, edited by Slobodan Selinić, 483-496. Belgrade: Institut za noviju istoriju Srbije, 2008. 



\title{
Yugoslav music diplomacy in the 1960s and 1970s- the cases of Esma Redžepova and the band Magnifico
}

\author{
Julijana Papazova
}

Can musical diplomacy improve international understanding? How can music contribute to cross-border interaction and intercultural communication? When was music included in economic diplomatic relationships? These are the questions that guided us in the research process to our results.

One of the starting points in the discussion about diplomacy and music is that music assists in diplomatic activities by accompanying ceremonies and celebrations, providing the atmosphere for important meetings, conferences, informal negotiations or inspiring an international order based on a harmonic model. In fact, similarities come into sight between these two areas: diplomacy, just as music, is mainly about practice. "It assumes experience-based know-how and a disposition and temperament reinforced by habituation of education all of which constitute [...] a way of being," as Jean-David Levitte (French representative to the UN in 2000-2002, and Ambassador to the US in 2002-2007) compares the diplomat to an artist who must exercise his scales by accessing all information resources set at his disposal. ${ }^{1}$

This research derives from Milton Cummings's definition of cultural diplomacy as the exchange of ideas, values, information and other aspects of culture, with the ultimate goal of fostering mutual understanding. Cummings's definition thus includes cultural relations and intercultural exchange. ${ }^{2}$ There are several conceptions about when music becomes part of international and intercultural relations. They rely on an expansion of musical material: sounds and voices are not limited to music per se. Therefore, music and also lyrics suggest an extension

\footnotetext{
1 Cécile Prévost-Thomas, Frédéric Ramel, "Introduction: Understanding Musical DiplomaciesMovements on the 'Scenes', in International Relations, Music and Diplomacy. Sounds and Voices on the International Stage, edited by Frédéric Ramel, Cécile Prévost-Thomas (London: Palgrave Macmillan, 2018), 1-2.

2 Milton Cummings, "Cultural Diplomacy and the United States Government: A Survey," in Americans for the Arts, June 26, 2009, https://www.americansforthearts.org/by-program/reports-and-data/ legislation-policy/naappd/cultural-diplomacy-and-the-united-states-government-a-survey.
} 
of strategic figurations. Recent analyses about music and international relations discuss the meaning of the self and the otherness. ${ }^{3}$

Along with intercultural relations in diplomacy in the sense of cultural diplomacy, I also use the term musical diplomacy in this research. The purpose is to examine how musical diplomacy sets the diplomatic scene by leading conducts and diplomatic relations on the basis of music. ${ }^{4}$ For this purpose, I will analyze two topics: (1) Esma Redžepova and the Stevo Teodosievski Ensemble-here, musical diplomacy focuses on the economic and cultural aspects in particular-and (2) Magnifico and Esma-here, cultural transfers and musical practices, which although recognized as Mexican or Roma, respectively, were in fact used by Yugoslav musicians for foreign policy (in other words, Yugoslav diplomacy toward the countries of the Non-Aligned Movement). The scene goes beyond the location or performances, it is also about the distribution or promotion of a musical style with the purpose of fostering intercultural exchange and good relations. At the same time, the focus is on analyzing the relationship between diplomacy and music in the policies of the Socialist Federal Republic of Yugoslavia (SFRY) toward the countries from the Non-Aligned Movement in the 1960s and 1970s.

The aim is to examine how music serves as a tool of diplomacy. Music and sounds are thus at the front line themselves, for example, when music becomes a diplomatic topic on the agenda of bilateral and multilateral diplomatic meetings or collaborations.

In his introductory remarks to a 2004 lecture under the title "Why Music Matters," Kofi Annan said: "In a world of diversity where often values clash, music leaps across language barriers and unites people of quite different cultural backgrounds. And so, through music, all peoples can come together to make the world a more harmonious place." ${ }^{5}$ With these words, the UN Secretary-General underlined the potential of music to raise faith and understanding. According to him, music can transcend geographical, cultural, political and economic barriers. Unfortunately, Kofi Annan is a rare example of people who acknowledge the potential of music for international cooperation and understanding. ${ }^{6}$

The Socialist Federal Republic of Yugoslavia was among the founders of the United Nations and also one of the founders of the Non-Aligned Movement. Yugoslav

\footnotetext{
3 Prévost-Thomas, Ramel, "Introduction: Understanding Musical Diplomacies-Movements on the 'Scenes', 7.

4 Ibid., 9.

5 Kofi Annan, "Music Unites People of Different Background," Introductory Remarks at the Lecture on "Why Music Matters" by Leon Botstein. United Nations Headquarters, New York City on November 8, 2004. According to Mary Einbinder, "Cultural Diplomacy. Harmonizing International Relations through Music," (MA Thesis. Gallatin School of Individualized Studies, New York University, 2013), 4.

6 Einbinder, "Cultural Diplomacy," 4-5.
} 
president Josip Broz Tito, as the key figure in the promotion of Yugoslav official policies, supported musicians, music associations and institutions in the global promotion of Yugoslav musical culture. In 1949, only a few years after new Yugoslav state was established, Tito told a conference of music delegates in Bled: "Yet, I still believe the world would be a better place if people spent more time making music."7

Both statements, Annan's and Tito's, lead this paper to argue for the promotion of musical diplomacy as a tool for harmonious diplomatic relations. The concept of "harmonizing international relations" was developed by Mary Einbinder in her research on cultural diplomacy. She argues for the promotion of music as an instrument of cultural diplomacy for improving intercultural communication and cooperation between the peoples of the world. ${ }^{8}$

Yugoslav diplomacy mostly focused on trade, economy and cultural exchange. As a part of regular diplomatic activity, cocktail parties or receptions were frequently organized in Yugoslav embassies, particularly around national holidays, such as Republic Day (November 29), or during foreign diplomatic visits. In the memoirs of diplomat Mihailo Stevović, who worked at the Yugoslav embassies in Rome, Washington and Tripoli, we can read that sometimes the receptions marking a particular event would be divided between two separate venues. For example, two Republic Day receptions were organized in Tripoli in 1975: one for Yugoslav citizens at the Yugoslav Club, and the other one in the residency of the Yugoslav Embassy for Yugoslavs and foreigners-members of the diplomatic corps. ${ }^{9}$

Josip Broz Tito was one of the initiators of the Non-Aligned Movement. His ideas and personal contribution, his close collaboration with Indian Prime Minister Jawaharlal Nehru and Egyptian President Gamal Nasser, and later also with Ghanaian President Kwame Nkrumah, Indonesian President Sukarno and other politicians, were all pieces in the mosaic that took shape as an integral political platform of non-alignment in Belgrade in the September 1961. From its very beginning, non-alignment was not a policy of status quo, but rather a policy of change. It was geared in the direction of: ensuring that there would be no more imperialist conquests, no more colonial or neocolonial forms of dependence; preventing a further expansion of the bloc division of the world and the establishment of their spheres of influence; opposing all other kinds of political hegemony, foreign domination, intervention and interference in the affairs of other countries. ${ }^{10}$

\footnotetext{
7 See Zija Kučukalić, “Josip Broz Tito 1892-1980,” Zvuk 1 (1980): 3.

8 Einbinder, "Cultural Diplomacy," 2.

9 Mihailo V. Stevović, Diplomatija i demokratija [Diplomacy and Democracy] (Belgrade: Prosveta, 2000), 211-212.

${ }^{10}$ Josip Vrhovec, “Tito, Non-Alignment, Contemporary Times," in Tito-Non-AlignmentContemporary Times, edited by Bojana Tadić, Vladimir Falatov (Belgrade: Josip Broz Tito Memorial Center, 1989), 13-15.
} 
Tito's voyages from the mid-1950s onward were also a preparation for the foundation of the Non-Aligned Movement. The first two visits to Asia and Africa were in 1954 and 1958. And Nehru and Nasser were received on the Brijuni Islands (also known as Brioni) ${ }^{11}$ in 1956. Tito's further major voyages to Asia and Africa took place at the beginning of 1961. As a result of these trilateral meetings, the second conference of the Non-Aligned Movement was held in Cairo in 1964. The whole period between the three trips was filled with bilateral or multilateral contacts, where connections and friendship developed with statesmen of the Third World. In this time, Tito developed his views about the need for better coordination of actions of Third World countries, and the trips are also known as journeys of peace. ${ }^{12}$

Musicology journal Zvuk honored Tito after his death with a series of texts dedicated to his legacy in music, particularly his appreciation of singers. It is known that no ceremony or reception was held in Belgrade or on the Brijuni without singers performing. Among such musicians were Miroslav Čangalović, Biserka Cvejić, Radmila Bakočević, Marijana Radev, Vladimir Ruždjak and Tito’s favorite singer Mario Del Monaco. ${ }^{13}$

But regular musical performances at political and diplomatic events in Yugoslavia are not only important as intercultural communication in the direction of musical diplomacy. According to John Blacking, this attitude also reflects one of the chief functions of music to "promote soundly organized humanity by enhancing human consciousness." 14 Thus, musical diplomacy should be analyzed through the lens of constructivism, which accepts the idea that international relations are created by norms and ideas, and the international structure leads actors to redefine their interests and identities in the process of interacting. ${ }^{15}$ In the diplomatic relations of Yugoslavia with the countries of the Non-Alignment Movement, the economic and political activities were in interaction with music. This leads us to the discussion on the diplomatic aspects of the activities of Esma Redžepova, the Stevo Teodosievski Ensemble and the group Magnifico.

\footnotetext{
11 The Brijuni are a group of fourteen small islands off the Croatian coast in the northern Adriatic. In the time of the SFRY, Tito made the islands his personal State Summer Residence. Apart from the regular political meetings, he also hosted a number of film stars at the summer residence at Brijuni: Elizabeth Taylor, Richard Burton, Sophia Loren, Carlo Ponti and Gina Lollobrigida.

12 Stanislav Stojanović, “Tito's Contribution to the Origination and Development of the NonAlignment Idea and Policy," in Tito-Non-Alignment-Contemporary Times, edited by Bojana Tadić, Vladimir Falatov (Belgrade: Josip Broz Tito Memorial Center, 1989), 76.

13 Slavko Zlatić, “Tito i muzika,” Zvuk 1 (1980): 5.

${ }^{14}$ John Blacking, How Musical is Man? (Seattle and London: University of Washington Press, 1974), 101.

15 Einbinder, “Cultural Diplomacy,” 18.
} 
Esma Redžepova-Teodosievska (1943-2016), was born on August 8, 1943 in Skopje in a very diverse family. Her father Ibrahim was a Catholic Roma, her mother Kanija a Muslim, and her parental grandmother Esma was an Iraqi Jew. As a student in the 1950s, Redžepova participated in a few school talent competitions, such as "Mikrofonot e vaš" (The Microphone is Yours) and a school competition in Saraj (a neighborhood in Skopje). Based on the very positive reception in these competitions, Redžepova was offered to record a song for Radio Skopje-the most important media for the recording and promotion of music in this part of Yugoslavia at that time. There, she was heard by Stevo Teodosievski (1924-1997), who played in the orchestra of Radio Skopje, and he decided to invite Esma to join his ensemble as a singer. From the 1960s until the end of the 1980s, Esma and Stevo Teodosievski lived in Belgrade. In 1968 they got married and soon went on their first big tour to Australia. Redžepova's most recognized songs include "Chaje Shukarije" (Beautiful Girl) and "Zašto si me majko rodila" (Mother, Why Was I Born). Her beauty, charm, striking voice and performance skills quickly made her famous across Europe and the world. ${ }^{16}$

Redžepova first sang for Tito in 1961, when he was hosting Indonesian President Sukarno in Belgrade. The same year, she also sang when the Non-Aligned Movement was established in Belgrade. She regularly performed for Libyan leader Muammar Gaddafi at his official visits in Belgrade and his summer visits to the Brijuni. Throughout the 1960s, she also very often performed at receptions for politicians and diplomats on the Brijuni. Usually she would give her records to the guest politicians as gifts. Tito especially advised Redžepova to be very kind at Gaddafi's visits. ${ }^{17}$ In the TV show "Balkanskom ulicom" (Up the Balkan Street) with hostess Vesna Dedić, Redžepova spoke about her collaboration with Tito. At one of Gaddafi's visits to Brijuni, Tito approached Esma and said to her: "Let's go to work and earn something." At the end of the visit, a weapons sale contract with Libya was concluded. Tito said that only the two of them had worked that day and earned something, so only they deserved double servings at dinner. ${ }^{18}$

In the 1960s, Esma and her ensemble performed a lot in Israel (charity concerts), then in Mexico, Pakistan and Iran. They even did a show at the Olympia in Paris in 1966, and there is an anecdote about this trip. At the same time when Esma and her ensemble arrived at the airport in Paris, French President Charles de

\footnotetext{
16 Slave Nikolovski-Katin, Esma Redžepova-Teodosievska (Skopje: Makedonska iskra, 2015), 1-20; Garth Cartwright, "Esma Redžepova obituary”, The Guardian (December 14, 2016): https://www. theguardian.com/world/2016/dec/14/esma-redzepova-obituary.

${ }^{17}$ Nikolovski-Katin, Esma Redžepova-Teodosievska, 12, 32, 264.

18 “Balkanskom ulicom, TV show. Interview of Vesna Dedić with Esma," http://www.rts.rs/page/ tv/sr/story/20/rts-1/74013/balkanskom-ulicom-esma-redzepova.html, 2009.
} 
Gaulle was returning from Moscow. His plane was late and the airport was crowded with journalists. While waiting for a live TV transmission from the airport, the French national TV put on Redžepova's songs, and one journalist even wrote that de Gaulle promoted Esma Redžepova. ${ }^{19}$

In her interviews, Esma constantly stressed her admiration for Tito, and the importance of Yugoslavia and Tito's policies for the development of culture and prosperity of the state.

Look, I adored Tito. I loved his policies. When we sang abroad, people knew where we were from when we said his name. I was growing up at the time and I can't say it was bad for me. You know, I sang at the first Non-Aligned Conference here in Belgrade. Me and the Branko Krsmanović Choir. Afterwards, Indira Gandhi said she wanted to meet Esma Redžepova, so general chaos ensued. It was a big problem how to arrange this meeting because it was out of protocol, so-among other things-they re-paved the street where I lived, even though it was paved. These were very beautiful and important things that I experienced, and it was an honor. ${ }^{20}$

Esma was also available to participate in unplanned meetings or protocol events on the highest political level.

I was often with Tito on his boat, going to different places where he was staying around former Yugoslavia. And whenever he was receiving someone, they would find me, wherever I was at that moment. I remember having a concert in a casino in Bosnia, and they came and took me to Dubrovnik. 21

The diplomatic musical activities of Esma and her ensemble can be divided into two groups: within Yugoslavia and on the international scene, mainly in the Middle East and Asia. During their career, the relationship of Esma and Stevo with India become very important for them. It was not just about their participation in diplomatic ceremonies and enhancing cooperation between India and Yugoslavia. It was also about the musical closeness between the Roma and Indian music and culture, as well as developing a better understanding and mutual respect for musicians and for the audience.

After touring Australia in 1968, the Teodosievski Ensemble went to Bombay, India, and held a concert for the Yugoslav consulate and the Yugoslav workers there (mainly construction workers). The concert for the diplomatic corps was

\footnotetext{
${ }^{19}$ Nikolovski-Katin, Esma Redžepova-Teodosievska, 194.

${ }^{20}$ Jelena Grujić, "Pesma može sve. Intervju Esma Redžepova [A song can do anything. Interview with Esma Redžepova]," Vreme (October 28, 2004): https://www.vreme.com/cms/view.php?id=394924. 21 "Pevala je Titu i Gadafiju: Esma je bila svetska zvezda ali uvek se vraćala u Skoplje [She sang for Tito and Gaddafi: Esma was a world star, but she would always return to Skopje]," Kurir (December 11, 2016): https://www.kurir.rs/stars/2583879/video-pevala-je-titu-i-gadafiju-esma-je-bila-svetska-zvezda-ali-uvek-se-vracala-u-skoplje.
} 
at the Hotel International. After that, they visited India two more times. One was the performance at the First Festival of Roma Music in Chandigarh (March 1976), where Esma was proclaimed the "Queen of Roma music." In that period, they once again met with President Indira Gandhi, who prepared a reception for them and they performed a concert at the presidential palace.

The initiative for Esma and Stevo to perform at the first Chandigarh festival came from Mr. Weer Rajendra Rishi, who came to Belgrade from India in 1974 to become the director of the Roma Institute there. At the time of the second International Roma Festival in Chandigarh in 1983, Esma and the Teodosievski Ensemble also performed at celebration in honor of the birthday of late Prime Minister Jawaharlal Nehru in his native town Allahabad.

In the mid-1970s, Esma and the Stevo Teodosievski Ensemble held long tours and numerous concerts in the Middle East. For example, they performed for three months at the Miami Hotel in Tehran. In the same period, they performed at diplomatic meetings at the Yugoslav Embassy in Tehran. Marking International Women's Day (March 8) in 1975, they held a concert at the Yugoslav Embassy, with Farah Pahlavi, wife of Iranian Shah Mohammad Reza Pahlavi, attending as a special guest. ${ }^{22}$

Throughout their careers, Esma and Stevo received honors, awards and presents from politicians such as Tito, Gandhi, Saddam Hussein, etc. In their home in Belgrade, they were visited by important politicians, like the previously mentioned Indira Gandhi. Esma and Stevo received Tito's golden and silver medals for the development of Yugoslav culture ${ }^{23}$. Their most active and important period in terms of diplomatic musical performances were the 1960s and 1970s. In the 1990s, Esma and Stevo moved from Belgrade to Skopje, to the so-called Home of Humanity and Museum of Music of Esma and Stevo Teodosievski. She continued to be active not only with concerts but also with charity activities and campaigns for children and women. Esma Redžepova-Teodosievska died on December 11, 2016 in Skopje.

\section{The band Magnifico}

Magnifico was a band founded in Skopje in 1959 that was active until 1990. The idea to form this band came from the high popularity of Mexican films throughout Yugoslavia in the 1950s, such as Un dia de vida (starring Columba Dominguez) and Serenta en México (starring Rosita Quintana). Also adding to the popularity of Mexican music in this period were concerts by Mexican musicians in Yugoslavia: Trio de Santa Cruz, Trio Barbosa, Los Panchos, etc. ${ }^{24}$ This new wave of Mexican

${ }^{22}$ Nikolovski-Katin, Esma Redžepova-Teodosievska, 58-66, 196.

${ }^{23}$ Ibid., 32.

24 Pantelej-Panče Kočovski, Ansamblot Manjifiko. Mit, legenda ili realnost [The Ensemble Magnifico. The Myth, the Legend or Reality] (Skopje: Magor, 2013), 21-22. 
music in Yugoslavia was known as "Yu-Mex" - the term refers to cover versions of Mexican music or a mix of Mexican music and local Yugoslav popular music and languages. In 1948, when Yugoslavia decided to choose its own direction and not follow the Soviet Union, Yugoslav Communist Party and Tito opened Yugoslavia more to the West, which meant freer presence of popular culture or rock and roll in public life.

"This rupture left the country in a very difficult position, in the middle between the Eastern bloc and the West," says Slovenian author Miha Mazzini, whose novel Paloma Negra is set in the glory days of Yu-Mex. ${ }^{25}$ This period of change, or movement from the Eastern Bloc into the new phase of Yugoslav policies of non-alignment between the East and the West fit well with the popularity of Mexican movies and music at the time. This popularity peaked in the 1950s and 1960 s, and with the late 1960s Yu-Mex music went into a rapid decline. Rock music became the dominant interest for young people.

The most consistent members of Magnifico were Panče Kočovski, Nevenka (Arsova) Kočovska, Krsto Taušanov and Dimitar Tomov. In its run, the band performed a total of over 3700 concerts on all continents, published $28 \mathrm{EPs}, 5 \mathrm{LPs}$,

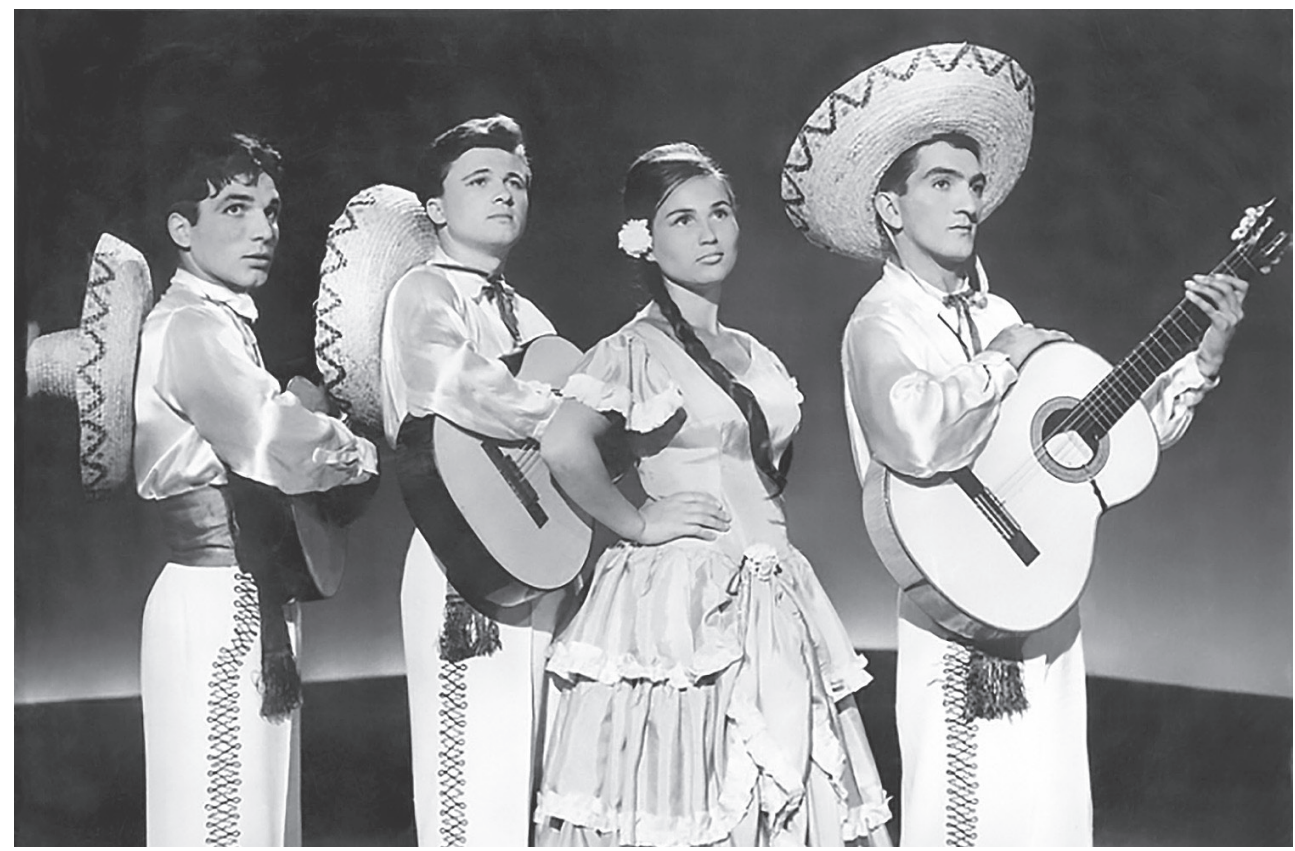

Figure 1. The band Magnifico in the 1960s. MKD.mk, https://www.mkd.mk/kultura/muzika/ansamblot-manjifiko-kje-dobie-nagrada-za-zhivotno-delo-na-zlatna-buba-mara-na.

25 Pablo Esparza, “In mid-'60s Yugoslavia, mariachi music was really popular.” Pri (September 25, 2017): https://www.pri.org/stories/2017-09-25/mid-60s-yugoslavia-mariachi-music-was-really-popular. 
4 cassettes, 1 video cassette, $1 \mathrm{CD}$ and 1 DVD. Their repertoire consisted mainly of Latin American music, as well as adaptations of evergreens and Macedonian folk tunes. Magnifico participated at diplomatic receptions in Belgrade when the guests were from Mexico. Original clothes from Mexico were procured for the band, specifically through the Mexican Embassy in Belgrade. It was often not advertised at Magnifico's concerts abroad where the band was from, so it was mistaken for an authentic Mexican one. ${ }^{26}$

The ensemble Magnifico performed at many state-organized events in the 1960s and 1970s. The most prominent performances of this sort included: three times at the annual Diplomatic Hunt near Novi Sad; a concert as part of the artistic program accompanying the official visit of Mexican President López Mateos to Belgrade; and a one-hour performance for Yugoslav President Josip Broz Tito and his wife Jovanka in Skopje, which was also attended by the political elite of the Socialist Republic of Macedonia (see Figure 2). ${ }^{27}$

The statements of politicians about Magnifico confirm the harmonizing aspect or purpose of music in diplomacy:

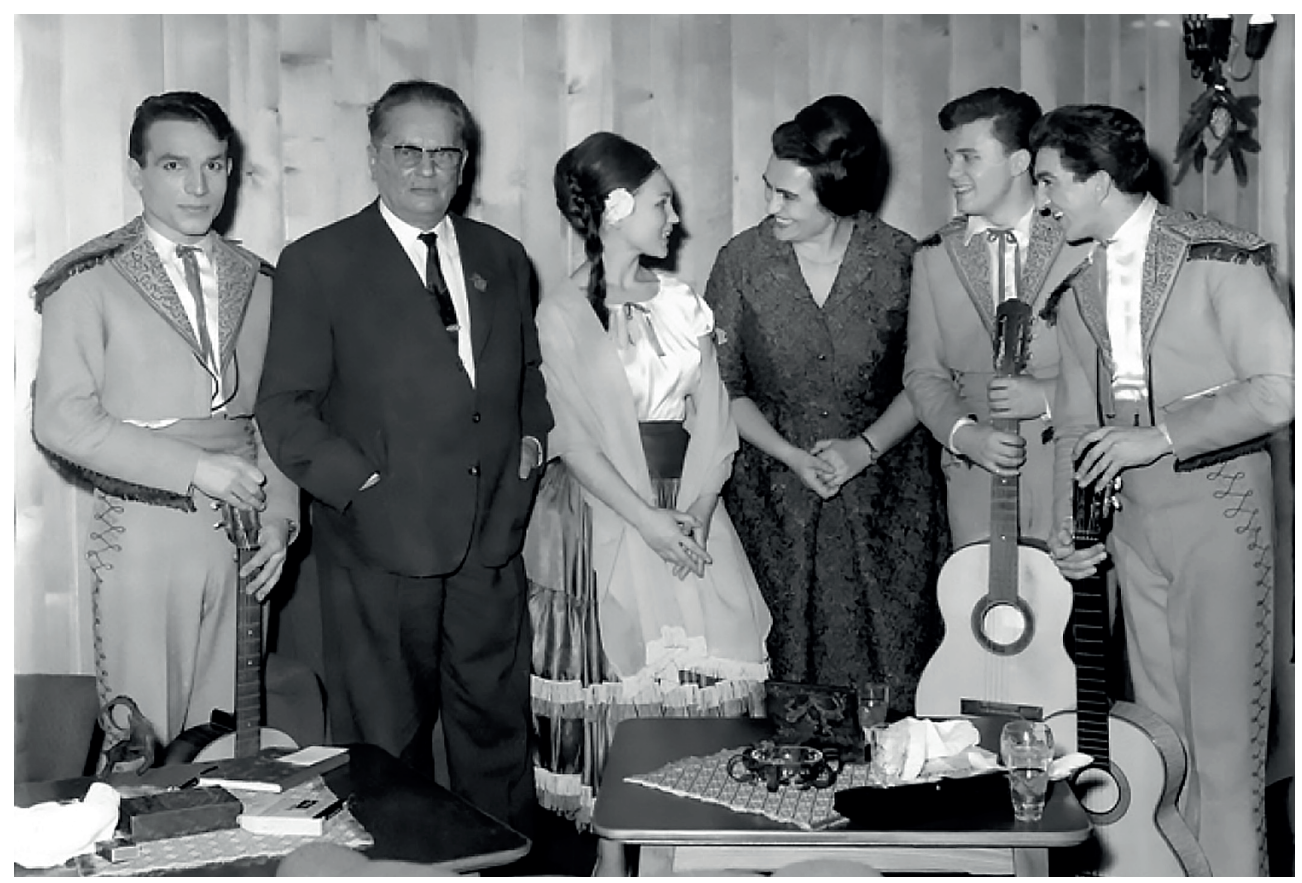

Figure 2. The band Magnifico with Tito and Jovanka after one of the

Diplomatic Hunts, 1960s. MKD.mk, https://www.mkd.mk/kultura/muzika/ ansamblot-manjifiko-kje-dobie-nagrada-za-zhivotno-delo-na-zlatna-buba-mara-na.

${ }^{26}$ Kočovski, Ansamblot Manjifiko, 30-50.

${ }^{27}$ Ibid., 274. 
With Magnifico, my country and my continent have become one artistic and diplomatic institution richer.

- Delfín Sánchez Juárez, Mexican Ambassador to Yugoslavia (1961-1965)28

I adore Magnifico and the unique alto of Nevenka.

- Jovanka Broz 29

As always, the ensemble Magnifico was once again magnificent.

- Josip Broz Tito ${ }^{30}$

I'm looking forward to the ensemble Magnifico visiting my country and other countries of the Latin American continent to impress the audience as the ensemble already impressed me.

- López Mateos, president of Mexico ${ }^{31}$

\section{Conclusion}

The activities of the music ensembles of Esma and Stevo Teodosievski and Magnifico bring to light the importance of musical diplomacy Yugoslavia pursued in its international diplomatic relations with the countries of the Non-Aligned Movement. The most suitable theory of international relations in the context of music and diplomacy is the creation of platforms for intercultural dialogue in the process of bilateral or multilateral exchange.

Not only did the performances of Esma and the Stevo Teodosievski Ensemble and of the band Magnifico have a significant positive impact on the improvement of intercultural dialogue between countries from different historical and political areas, but they also partly contributed to the economic diplomacy of Yugoslavia in the countries of the Middle East. This is particularly evident in the role of Esma Redžepova as a performer and a part of the diplomatic protocols during formal receptions.

As previously mentioned, this research supports the acknowledgement of the potential and value of music in harmonizing international relations. As constructivists state, "the international system only exists as a common understanding among people." 32 This perspective confirms, the contribution of musicians and their concerts, as well as their role in the active and productive diplomatic relations pursued by the SFRY in the 1960s and 1970s.

\footnotetext{
28 Ibid., 277.

29 Ibid., 278.

${ }^{30}$ Ibid.

${ }^{31}$ Ibid., 277.

32 Einbinder, "Cultural Diplomacy," 18.
} 


\section{Internet sources:}

"Balkanskom ulicom, TV show. Interview of Vesna Dedić with Esma." http://www.rts.rs/ page/tv/sr/story/20/rts-1/74013/balkanskom-ulicom-esma-redzepova.html, 2009.

\section{References:}

Blacking, John. How Musical is Man? Seattle and London: University of Washington Press, 1974.

Cartwright, Garth. "Esma Redžepova obituary." The Guardian (December 14, 2016): https://www.theguardian.com/world/2016/ dec/14/esma-redzepova-obituary.

Cummings, Milton. "Cultural Diplomacy and the United States Government: A Survey." In Americans for the Arts, June 26, 2009, https://www.americansforthearts.org/by-program/reports-and-data/ legislation-policy/naappd/cultural-diplomacy-and-the-united-states-government-a-survey.

Einbinder, Mary. "Cultural Diplomacy. Harmonizing International Relations through Music." MA Thesis, Gallatin School of Individualized Studies, New York University, 2013.

Esparza, Pablo. “In mid-'60s Yugoslavia, mariachi music was really popular." Pri (September 25, 2017): https://www.pri. org/stories/2017-09-25/mid-60s-yugoslavia-mariachi-music-was-really-popular.

Grujić, Jelena. "Pesma može sve. Intervju Esma Redžepova.” Vreme (October 28, 2004): https://www.vreme.com/cms/view. php?id=394924.

Kočovski, Pantelej-Panče. Ansamblot Manjifiko. Mit, legenda ili realnost. Skopje: Magor, 2013. [Orig. in Macedonian Cyrillic]

Kučukalić, Zija. “Josip Broz Tito 1892-1980.” Zvuk 1 (1980): 2-3.
Nikolovski-Katin, Slave. Esma Redžepova-Teodosievska. Skopje: Makedonska iskra, 2015. [Orig. in Macedonian Cyrillic and English]

"Pevala je Titu i Gadafiju: Esma je bila SVETSKA ZVEZDA ali uvek se vraćala u Skoplje." Kurir (December 11, 2016): https://www.kurir.rs/stars/2583879/videopevala-je-titu-i-gadafiju-esma-je-bila-svetska-zvezda-ali-uvek-se-vracala-u-skoplje.

Prévost-Thomas, Cécile, Ramel, Frédéric. "Introduction: Understanding Musical Diplomacies-Movements on the 'Scenes." In International Relations, Music and Diplomacy. Sounds and Voices on the International Stage, edited by Frédéric Ramel, Cécile Prévost-Thomas, 1-20. London: Palgrave Macmillan, 2018.

Stevović, Mihailo. V. Diplomatija $i$ demokratija. Belgrade: Prosveta, 2000. [Orig. in Serbian Cyrillic]

Stojanović, Stanislav. “Tito's Contribution to the Origination and Development of the Non-Alignment Idea and Policy." In TitoNon-Alignment-Contemporary Times, edited by Bojana Tadić, Vladimir Falatov, 69-78. Belgrade: Josip Broz Tito Memorial Center, 1989.

Vrhovec, Josip. “Tito, Non-Alignment, Contemporary Times." In Tito-NonAlignment-Contemporary Times, edited by Bojana Tadić, Vladimir Falatov, 13-19. Belgrade: Josip Broz Tito Memorial Center, 1989.

Zlatić, Slavko. “Tito i muzika.” Zvuk 1 (1980): 4-5. 



\title{
Cultural cooperation between the non-aligned Yugoslavia and the neutral Finland from the 1960s to the 1980 s
}

\author{
Maja Vasiljević
}

As a direct successor to Yugoslavia, the Republic of Serbia celebrated in 2019 ninety years of diplomatic relations with Finland with an exhibition held at the Archives of Yugoslavia. With little interest in this topic even among researchers, it was not surprising that on this occasion the Finnish and Serbian foreign ministers, Pekka Haavisto and Ivica Dačić, were stuck on the general topic of EU integration of the Western Balkans, without any link to the exhibition they opened or reference to the shared past. ${ }^{1}$ Based on suggestive pictures from the Archives of President Urho Kekkonen in Niinikoski and domestic sources, the emphasis of this exhibition was on the close ties between the countries' two long-term presidents, Josip Broz Tito (1892-1980) and Urho Kaleva Kekkonen (1900-1986), ${ }^{2}$ and their mutual visits. ${ }^{3}$ Although independent Finland and the Kingdom of Serbs, Croats and Slovenes (later renamed as the Kingdom of Yugoslavia) established diplomatic ties in the interwar period, in August 1929, the subsequent Yugoslav war-torn history and the international reception of the Yugoslav wars for succession have diminished and

\footnotetext{
1 The event was accompanied by a catalogue in which the introduction, presenting the main points from the history relations between Finland and Yugoslavia, is followed only by a list of exhibition material with archival signatures, arranged according to three topics: mutual visits of presidents, cultural and educational relations, and trade agreements. See Jelena Đurišić (Ed.), Beograd-Helsinki: 90 godina diplomatskih odnosa. katalog izložbe / Belgrade - Helsinki: 90 Years of Diplomatic Relations, exhibition catalogue (Belgrade: Archives of Yugoslavia, 2019).

2 See media reports on this event: "Dačić i Havisto otvorili izložbu Beograd-Helsinki, 90 godina diplomatskih odnosa," https://www.rts.rs/page/stories/sr/story/9/politika/3680542/dacic-i-havisto-otvorili-izlozbu-beograd-helsinki-90-godina-diplomatskih-odnosa.html; http://www.diplomacyandcommerce.rs/the-exhibition-belgrade-helsinki-90-years-of-diplomatic-relations/.

3 Kekkonen, who visited Yugoslavia three times, in 1963 (Belgrade, Kotor, Cetinje, Brijuni, Dubrovnik, Split, and Pula), 1967 (also in Mostar) and 1975, was succeeded in 1981 by Mauno Koivisto (1923-2017), who also visited Yugoslavia in 1986. Tito was accompanied on his first visit to Finland in 1964 by Minister of Foreign Affairs Koča Popović (1908-1992), while the second time he went to Finland was on the occasion of the Helsinki Final Act meeting in Finlandia Palace in 1975. For a more detailed list of diplomats connected to Finnish-Yugoslav relations, see Đurišić (Ed.), Beograd-Helsinki, 10-11, 13-14.
} 
obscured the importance of earlier decades of cooperation between the Socialist Federal Republic of Yugoslavia (SFRY) and Finland in peacemaking and conflict resolution starting in the 1960s. We assume that another reason for the lack of interest in this topic is the change in the political atmosphere in Serbia in the 1990s, with a revision of history which sometimes left no room for observing the "peaceful episodes" in Yugoslav history.

As one of the first steps in the still establishing discourse about FinnishYugoslav cultural relations from the Yugoslav or Serbian perspective, we singled out the decades from the 1960s to the 1980s. Based on concrete facts from the Finnish-Yugoslav relations, we find cultural cooperation between the two countries theoretically and scientifically relevant for two reasons. First, this was the period of the most intensive relations between these two countries, which can be considered as a part of a broader context, and this also makes it more interesting for readers. The second reason is the researchers' personal intention to emphasize the often forgotten part of Yugoslav-and with that our-political and diplomatic heritage as peacemakers during the Cold War. ${ }^{4}$ In this respect, it is important to understand that the highlighted period was the only quiet episode in Yugoslav history. Yugoslavia acted in its foreign policy as a peaceful diplomatic oasis dedicated to mediation and bringing together other countries on the premises of its socialist Sonderweg, which was completely innovative even from today's perspective. ${ }^{5}$

Based on the view that small powers in the Cold War should not be underestimated, our approach to Finnish-Yugoslav cultural relations will be through the "pericentric lens," or to use the words of Croatian historian Tvrtko Jakovina, through the perspective of the "third side in the Cold War." ${ }^{\circ}$ In this sense, Jakovina observed: "The Cold War can be viewed through pericentric glasses: peripheral, small and less developed countries were often catalysts or initiators of Cold War conflicts. Therefore, analyzing the relations between the North and the South,

\footnotetext{
4 For a pericentric perspective of the Cold War, see Tony Smith, "New Bottles for New Wine: A Pericentric Framework for the Study of the Cold War," Diplomatic History 24/4 (2000): 567-591.

5 The innovative approach of the SFRY and its leader Tito in the Cold War bloc division has been illuminated from different perspectives by numerous scholars, especially historians interested in Tito's historical "No" to Stalin, as well as by authors who primarily focused on the foreign policies in this period. On the main premises of the SFRY's foreign policy, see Tvrtko Jakovina, Treća strana Hladnog rata [The Third Side in the Cold War] (Zagreb: Fraktura, 2011); Marija Krstić, "SFR Yugoslavia during the Cold War and current Serbian foreign policy," Anthropology: Journal of the Center for Ethnological and Anthropological Research 11/1 (2011): 21-44; John R. Lampe, Yugoslavia as History. Twice There Was a Country (Cambridge: Cambridge University Press, 2000), 207-252; Leo Mates, Medunarodni odnosi Socijalističke Jugoslavije [The International Relations of Socialist Yugoslavia] (Belgrade: Nolit, 1976); Branko Petranović "Otpor monolitizmu u Komunističkom pokretu i vanblokovska politika Jugoslavije [Resistance to monolithism in the Communist movement and the non-aligned policy of Yugoslavia]," in Istorija Jugoslavije 1918-1988: Socijalistička Jugoslavija 1945-1988. Vol. III (Belgrade: Nolit, 1988), 357-379.

6 Cf. Jakovina, Treća strana Hladnog rata.
} 
rather than the East and the West, allows us to better understand the Cold War. Small states have often played an important role in international relations, and their whims and behavior have forced superpowers to make moves they would otherwise not have made." 7 Elevating this into a strategy, finding interest in the periphery of the global Cold War process or multilayered phenomenon, which somehow forces superpowers, the Yugoslav and Finnish presidents' similar values of "non-alignment" and "neutrality" in foreign policy brought them to the principle of pacifism, opposing the arms race and searching for other ways of cooperation between European countries.

We agree with Finnish historians Pauli Kettunen and Joana Aunesluoma, who propose three levels of analysis for the Cold War phenomenon. On the first level, the Cold War is a political and military confrontation between the Eastern and the Western Bloc, dominated by the Soviet Union and the United States, respectively. The second level of analysis pertains to the conflict between socioeconomic systems-socialism and capitalism-and the third to the conflict between political approaches, including democracy, citizenship and human rights, that is the rivalry between different visions of human action and relations between individuals, the state and the society. ${ }^{8}$ As we can see from earlier research on this topic, cultural cooperation is also a special form of scientific abstraction in the discourse on the Cold War, and cultural cooperation as an integral part of a state's foreign policy is the most commonly addressed topic linking culture and the Cold War. ${ }^{9}$ However, studying culture in the context of the Cold War is complex, and authors usually focus on all types of communication between different countries, citizens, nations and their delegates (artists, scholars, performers in the case of music and theatre) who had connection to global political events. Still, even with enormously rich and popular discourse on culture and Cold War relations, it remains the task of researchers to first distinguish the different angles and interests of different countries from each other, as well as the channels of their cultural communication, which allows them to then explore the possibilities for comparative research.

Therefore, in order to conduct an in-depth analysis of the Finnish-Yugoslav cultural cooperation from the 1960s through the 1980s, we first collected data on their cultural cooperation in general. Research took us from official reports published in the journal Jugoslovenski pregled (Yugoslav Survey) and a rich collection of press-clipping material from all newspapers and magazines of former Yugoslavia, archived at the

7 Ibid., 24.

8 Cf. Pauli Kettunen, Joana Aunesluoma, "History in the Cold War and the Cold War in the Present," in The Cold War and the Politics of History, edited by Joana Aunesluoma, Pauli Kettunen (Helsinki: Edita Publishing Ltd, University of Helsinki, Department of Social Science History, 2008), 11-14.

9 Cf. Maja Vasiljević, "View to Cold War Through Pericentric Lenses: Tito’s Yugoslavia and Kekkonen's Finland," Limes plus (Special edition on the Cold War) 1 (2013): 12-13. 
Documentation Department of Radio Belgrade under "Relations between Yugoslavia and Finland," to program records of the main cultural institutions. ${ }^{10}$ Finally, we had to fill the gaps in the mentioned sources with extended research into political discourse, where we found the missing answers. ${ }^{11}$ In this phase, we collected data as mentioned as a sort of starting point for studying cultural diplomacy: all types of communication between different countries, citizens, nations, and their delegates.

In the second phase, we singled out (1) the main issues that guided the positions of Finland and Yugoslavia in the multilayered Cold War divisions, and then (2) the main similarities between them. Specifically, we were looking for these two points from the perspective of their influence on culture. It is interesting to note that both countries shared the same problematic issues (with a high probability of influencing cultural policies) of having to navigate in the hot-and-cold relations with the Soviet Union, and only then staying secure in the middle between the East and West.

In this sense, it is interesting to explore how these two seemingly very different states-the communist one-party and federal Yugoslavia and the Northern European multi-party Republic of Finland, which had historically been part of Russia-sought their place symbolically viewed as outside the paradigm of the Iron Curtain. Surprisingly, they had a similar approach to the Cold War, with their main rule being to try and cut the Iron Curtain with their peculiar and brave ideas and a strategy of maintaining a neutral position in the overall division. This observation and understanding of the "painful" issues for Finland and Yugoslavia led us to the consideration about the enormous importance of Russian classical music for both countries, or the influence of Byzantine art, or any other art where historical connections with Russia were obvious. In doing so, we understood how complex and blurred the macro and micro levels of research were in this case, and how important it is to hold onto exact facts. Therefore, this paper is focused specifically on how and on what grounds Finland and the SFRY established their cultural cooperation in the turbulent times of the global bloc division. In this sense, we focused on the question how macro-political events, concepts, values etc. influenced an aspect of the Cold War that is more on the micro level-cultural diplomacy.

\footnotetext{
10 Since our focus here are only the results of cultural cooperation between Finland and Yugoslavia, readers interested in the complete process of establishing the practice of agreements and organizing issues of cultural cooperation should see the Archives of Yugoslavia [Arhiv Jugoslavije (AJ)], Yugoslav Commission for Cooperation with the UN on Education, Science and Culture [Jugoslovenska Komisija za saradnju sa OUN za prosvetu, nauku i kulturu] (534); AJ, Federal Commission for International Cultural Links [Savezna komisija za međunarodne kulturne veze] (559).

${ }^{11}$ For more on Finnish foreign policy, see Rinna E. Kullaa, Non-Alignment and Its Origins in Cold War Europe: Yugoslavia, Finland and the Soviet Challenge (London: I. B. Tauris, 2012); Pauli Laitinen, "Međunarodni ekonomski odnosi Finske u razdoblju od 1956. do 1975. godine [The international relations of Finland in the period from 1956 to 1976]," In Urho Kekkonen: Borac za mir, edited by R. Vukadinović (Zagreb: Globus, 1977), 143-164.
} 
The basis for cultural cooperation between Finland and Yugoslavia from the 1960s to the 1980s lay in the understanding of the key concepts of their foreign policy- "neutrality" and "non-alignment." On the general level, Tito and Kekkonen agreed on the most important foreign policy concepts they promoted from the 1960s-neutrality in the case of Finland and non-alignment in the case of Yugoslavia. Rinna Kullaa, a leading expert on Eastern European and Russian foreign policy from Columbia University and the only scholar focusing on the Yugoslav-Finnish political connections concluded in her $\mathrm{PhD}$ thesis that the concept of neutrality was the basis for the split between Tito and Stalin, and came before the concept of non-alignment. ${ }^{12}$ Kekkonnen started to support the idea of non-alignment after his meeting with Tito in 1963, when Tito explained to him that it was "incorrect to understand the Belgrade Conference in 1961 as an attempt to create a third bloc." ${ }^{13}$ As president of a country at the crossroads between the East and West, Kekkonen easily noticed many similarities with Tito's ideas, particularly in terms of the so-called non-bloc management policy. They agreed as opponents of nuclear experiments and the arms race, and finally on the "policy of non-alignment and peaceful co-existence." 14

Although Tito and Kekkonen remain controversial figures in research between the East and the West in the given historical period, we have to emphasize for the purpose of this paper that the personal tastes of these authoritarian leaders were followed by artists and cultural activists. In line with this, the field of cultural cooperation was completely under the influence of the mainstream political constellations and thus guided by the two leaders, which was typical of this "era of presidents." 15

Similarities between these two countries and leaders were reflected in the concepts, establishment and activities of two important political projects/bodies - the Non-Aligned Movement (NAM) and the Conference on Security and Cooperation in Europe (CSCE). ${ }^{16}$ In both these projects, Finland and Yugoslavia

\footnotetext{
12 See more in Rinna E. Kullaa, "From the Tito-Stalin Split to Yugoslavia's Finnish Connection: Neutralism before Non-Alignment, 1948-1958," (PhD diss., University of Maryland, 2008).

${ }^{13}$ Cf. Rinna E. Kullaa, "The Birth and Development of the CSCE: Finnish and Yugoslav Models for Neutrality in the Early Cold War," in From Helsinki to Belgrade: The First CSCE Follow-up Meeting and the Crisis of Détente, edited by Vladimir Bilandžić, Dittmar Dahlmann, Milan Kosanović (Internationale Beziehungen: Theorie und Geschichte, 10. Gottingen: Bonn University Press, 2012), 46.

${ }^{14}$ For more on the topics they agreed on, see "Odnosi Jugoslavije i Finske [Relations between Yugoslavia and Finland].” Jugoslovenski pregled 12 (1966): 483.

${ }^{15}$ For more on Kekkonen's foreign policy and approach to politics, see Radovan Vukadinović (Ed.), Urho Kekkonen: Borac za mir [Urho Kekkonen: A Peace Fighter] (Zagreb: Globus, 1977).

${ }^{16}$ See more in Vladimir Bilandžić, Dittmar Dahlmann, Milan Kosanović (Eds.), From Helsinki to Belgrade: The First CSCE Follow-up Meeting and the Crisis of Détente (Internationale Beziehungen: Theorie und Geschichte, 10. Gottingen: Bonn University Press, 2012).
} 
as small powers acted as mediators, collaborators or assistants of great powers, or even the joining element for numerous other countries-like Tito with the Non-Aligned Movement or the CSCE for security issues. ${ }^{17}$ Strong political ties from the 1950s helped the two countries easily establish cultural diplomacy in the 1960s.

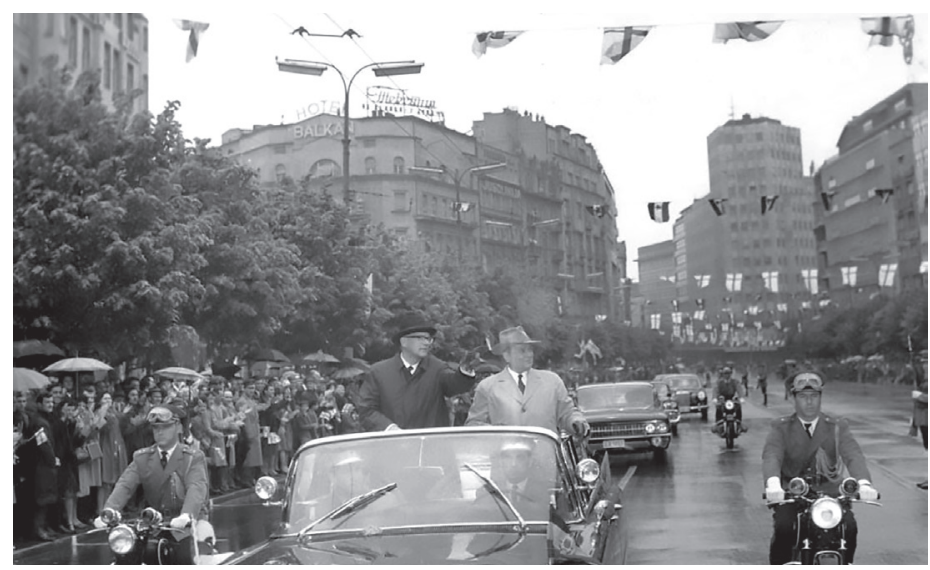

Figure 1. Kekkonen and Tito driving through the Terazije square in Belgrade on May 5, 1963. ${ }^{18}$ Archives of President Urho Kekkonen, 6-78-1963 Yugoslavia 0076.

Official institutional cooperation between Finland and the SFRY developed after mutual visits of their presidents and after agreements were signed. First, during Kekkonen's visit to Yugoslavia in 1963 and Tito's 1964 visit to Finland, the two leaders agreed on cooperation with non-aligned countries in the field of industry, and in addition, signed a number of agreements on international transport, health and other areas, but without establishing economic relations. Therefore, we can see that the process was hard and diplomacy-driven. A report in the journal Jugoslovenski pregled says the following of their relations from 1966 to 1975:

In spite of very good political relations and mutual interests for development of industrial, technical and scientific cooperation and joint presence on third markets, actual economic cooperation is not carried out in

\footnotetext{
17 The Helsinki Process directly lead to the Belgrade follow-up conference and the establishment of the CSCE, which was later succeeded by the Organization for Security and Cooperation in Europe (OSCE). This fact is often forgotten, along with Yugoslavia's role as an allied country in this project. In addition, good insight into the foreign policies of these two countries can be gained by looking into the events between the conferences in Helsinki in 1973 and the Belgrade meetings of 1977-1978. For an in-depth discussion on this issues, see Kullaa, "The Birth and Development of the CSCE."

${ }^{18}$ Cf. Đurišić, Beograd-Helsinki, 44. This photograph is kept in the Archives of President Urho Kekkonen in Niinikoski.
} 
accordance with the abilities and needs of the two countries' economies, although significant progress has been made. ${ }^{19}$

Although the economy was without a doubt an important topic for the two countries caught between the interests and agreements of the East and West, it is interesting to note that that soft power or cultural diplomacy ${ }^{20}$ made better, easier and faster progress, not only in the abovementioned nine-year period, but also until the end of the 1980s. The same report reveals how Finland and Yugoslavia cooperated in this period in the field of science, but also in high art practices, such as visual arts, architecture, literature, music and film. Therefore, apart from successful diplomatic cooperation in politics, these two countries were connected institutionally in the field of culture for decades. Even before formal agreements were signed, we can find data about institutional dialogue between these two countries, starting as early as 1960 . One of the first artistic events was a concert held on April 15, 1959 at the Kolarac Hall in Belgrade, when internationally renowned Finnish opera singer, bass-baritone Kim Borg (1919-2000), accompanied by Slovenian pianist Pavel Šivic (1908-1995), performed songs of Mozart, Haydn, Schubert, Ravel, Sibelius, and Mussorgsky. ${ }^{21}$

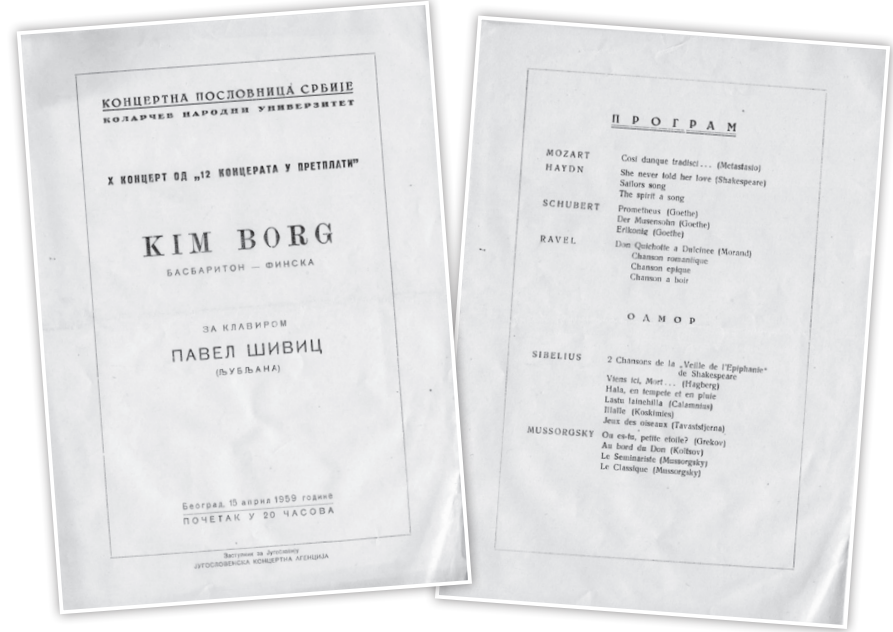

Figure 2. Concert program of Kim Borg and Pavel Šimic, April 15, 1959.

Milenko Petković's private collection, https://jugosvirke.wordpress.com/.

\footnotetext{
${ }^{19}$ Cf. "Odnosi Jugoslavije i Finske [Relations between Yugoslavia and Finland]," Jugoslovenski pregled 3 (1975): 127.

20 See Milton C. Cummings, Cultural Diplomacy and the United States Government: A Survey (ICD Institute for Cultural diplomacy, Centre for Arts and Culture, 2003).

${ }^{21}$ Like many other Finnish musicians who returned to Yugoslavia more than once, Borg performed again in Belgrade in 1968, according to program reports of the Jugokoncert agency from Belgrade.
} 
It is interesting how musicians found their way to connect even without official mediation of high political institutions. Although we found scattered musical events as proof of previously existing Finnish-Yugoslav artistic respect, official cultural exchange between Finland and the SFRY started with literature, which was only then followed by visual arts, film, music, theater and science. In 1966, the two countries signed their first formal plan for cooperation in the areas of culture and science, renewed in 1973 when Finland and Yugoslavia signed the Agreement on Bilateral Cooperation in the Fields of Culture, Science and Education. ${ }^{22}$ This cooperation continued through the 1980s, and was confirmed with the Agreement on Cultural Cooperation (1985-1987). But most importantly, the two countries established a general strategic plan for cooperation, covered by the Program for Cultural Cooperation between Finland and Yugoslavia.

On the one hand, we can conclude from the timeline of their cooperation that the first step in their cultural exchange were translations of their respective leading literary works; Finnish to Serbian and Serbian to Finnish. Books by writer and diplomat Ivo Andrić (1892-1975) were groundbreaking in this respect. For example, his novel $\mathrm{Na}$ Drini ćuprija (The Bridge on the Drina, 1945) was translated into Finnish even before he was awarded the Nobel Prize in Literature in 1961, when translations of his Gospodica (The Young Lady) and Travnička hronika (Travnik Chronicle) also came out. Apart from Andrić, books by Miodrag Bulatović (1930-1991) and Dobrica Ćosić (1921-2014) were also translated into Finnish. Likewise, numerous classical or contemporary Finnish writers were translated into Serbian. Probably the most popular example is the novel Ihmiset suviyössä (People in the Summer Night, 1934) by Frans Eemil Sillanpää (1888-1964), the Nobel Prize laureate of 1939. Other translations include Tuntematon sotilas (The Unknown Soldier, 1954) by Väinö Linna (1920-1992), The Adventurer (Mikael Karvajalka, 1948), The Wanderer (Mikael Hakim, 1949) and Turms kuolematon (The Etruscan, 1955) by Mika Waltari (1908-1978), Seitsemän veljestä (Seven brothers, 1870) by Aleksis Kivi (1834-1872) and the documentary novel Raft of Despair (1954) by Ensio Tiira (1929-1981). The linguistic exchange between these two countries was finally crowned in the period of the Agreement on Cultural Cooperation (1985-1987), including a celebration of the $200^{\text {th }}$ birthday of language reformist and linguist Vuk Stefanović Karadžić (1787-1864), as well as events related to the Finnish language in Novi Sad and to Serbo-Croatian in Helsinki.

On the other hand, looking through all the activities within the Program for Cultural Cooperation between Finland and Yugoslavia, we noticed a predominance of exchanges of visual and applied arts exhibitions (Table 1).

\footnotetext{
${ }^{22}$ On agreements in this period, see “Odnosi Jugoslavije i Finske," (1975).
} 


\begin{tabular}{|c|c|c|}
\hline \multirow{2}{*}{ Year } & Name of event & \multirow{2}{*}{$\begin{array}{l}\text { Artist exhibited } \\
\text { and main exhibits }\end{array}$} \\
\hline & Place of event & \\
\hline \multirow[t]{2}{*}{1964} & Finnish form & \multirow{2}{*}{ Alvar Alto } \\
\hline & Museum of Arts and Crafts in Zagreb & \\
\hline \multirow[t]{2}{*}{1965} & Contemporary Finnish visual art & \multirow{2}{*}{$\begin{array}{l}\text { Juhani Linnovaara (1934), Tuomas vom } \\
\text { Boehm (1916-2000) }\end{array}$} \\
\hline & $\begin{array}{l}\text { Museum of Contemporary Art in } \\
\text { Belgrade }\end{array}$ & \\
\hline \multirow[t]{2}{*}{1965} & $\begin{array}{l}25 \text { years of the Dubrovnik Summer } \\
\text { Festival }\end{array}$ & \multirow{2}{*}{$\begin{array}{l}\text { Organized by the Ministry of Culture } \\
\text { and featuring Finnish minister Marjatta } \\
\text { Väänänen as keynote speaker }\end{array}$} \\
\hline & Novi Sad, Stockholm and Helsinki & \\
\hline \multirow[t]{2}{*}{1966} & Finnish Applied Arts & \\
\hline & $\begin{array}{l}\text { Exhibition space on Masaryk Street } \\
\text { in Belgrade }\end{array}$ & \\
\hline 1974 & $\begin{array}{l}\text { Review of Contemporary Yugoslav Art } \\
\text { Helsinki, Tampere }\end{array}$ & \\
\hline \multirow[t]{2}{*}{1975} & & \multirow{2}{*}{$\begin{array}{l}\text { 15 Finnish graphic artists from Lahti, } \\
\text { including Kosti Ahonen (1920), Olavi } \\
\text { Rikle (1917), Rauno Salinnen (1949), Mati } \\
\text { Koskel, Ani Ukonen, Antero Olin, Enja } \\
\text { Markannen } \\
\end{array}$} \\
\hline & $\begin{array}{l}\text { Graphic Collective Gallery in } \\
\text { Belgrade }\end{array}$ & \\
\hline \multirow[t]{2}{*}{1977} & 15 Finnish artists & \multirow{2}{*}{$\begin{array}{l}\text { Visual art and sculptures by Juhani } \\
\text { Linnovaara, Rainno Haitinen, Juhani } \\
\text { Hari, Juhani Hakalahti, Kirsti Muinnonen, } \\
\text { Kiimo Piiko }\end{array}$} \\
\hline & $\begin{array}{l}\text { Museum of Contemporary Art in } \\
\text { Belgrade }\end{array}$ & \\
\hline \multirow[t]{2}{*}{1977} & 15 Finnish artists & \multirow{2}{*}{$\begin{array}{l}\text { Hakalahti Juhani, Harri Juhani, Reino } \\
\text { Hietanen, Outi Ikkala, Antti Jantunen, } \\
\text { Kauko Lehtinen, Juhani Linnovaara, Ukri } \\
\text { Merikanto, Kirsti Muononen, Marika Mäkelä, } \\
\text { Arto Pennanen, Gunnar Pohjola, Kimmo } \\
\text { Pyykö, Pauli Pyykölä and Kain Tapper }\end{array}$} \\
\hline & Yugoslav Portrait Gallery in Tuzla & \\
\hline \multirow[t]{2}{*}{1977} & Helsinki & \multirow{2}{*}{ Alvar Alto's Finlandia (1971) plan } \\
\hline & Center for Culture in Belgrade & \\
\hline \multirow[t]{2}{*}{1980} & $\begin{array}{l}\text { Tradition and identity-Architecture } \\
\text { in Finland }\end{array}$ & \multirow{2}{*}{$\begin{array}{l}300 \text { exhibits, including Eliel Saarinen's } \\
\text { urbanistic plan for Canberra, Willy Revel, } \\
\text { Kaija and Heikki Siren, Alvar Alto, Timo } \\
\text { Penttilä }\end{array}$} \\
\hline & $\begin{array}{l}\text { Museum of Contemporary Art in } \\
\text { Belgrade }\end{array}$ & \\
\hline
\end{tabular}

Table 1. Exhibitions as part of cultural cooperation between Finland and Yugoslavia 1964-1985 (selection). ${ }^{23}$

\footnotetext{
${ }^{23}$ For more details on these events, see the following articles from the Press clipping collection of Yugoslav newspapers and magazines kept at the Documentation Department of Radio Belgrade in the Yugoslavia and Finland Fond: Zoran Markuš, "Savremena finska umetnost [Contemporary Finnish art]," Borba (March 10, 1977); Prvoslav Mitić, "Dva smera finske umetnosti [Two directions
} 
Apart from the exchanges of exhibitions of visual and applied arts, the Program for Cultural Cooperation included the organization of interdisciplinary events between Finland and the SFRY, with mix of both high and popular art. While art exhibitions targeted mainly diplomatic representatives and art experts, these interdisciplinary festival-type events attracted the broader public from the two countries and received more attention in the public space. An institution that also brought together a diverse audience and merged high artistic practices with more popular ones was the Suomi-Jugoslavia seura (the Society of Friendship between Finland and Yugoslavia). ${ }^{24}$ Founded already in 1957, long before the official cultural agreements of the two countries, Suomi-Jugoslavia seura organized numerous events for decades. To highlight only one of them, the most important one of them was the Yugoslav Week in Finland, with an exhibition on the 25 years of the Dubrovnik Summer Festival. The event also featured a guest performance by soloists of the Zagreb opera, baritone Vladimir Ruždjak (1922-1987)25 and soprano Nada Siriščević (1934-2012), later married to Ruždjak, while one of the most distinguished chamber music ensembles from former Yugoslavia, the Zagreb Quartet, also gave a concert in the Finnish capital.

The Days of Yugoslavia in March 1989 were one of the last such mixed events before the dissolution of the SFRY that were organized as part of this program, in this case with the participation of the International Women's Club. The event had a strong focus on folklore, and ambassadors' wives dressed in the folk costumes of their friendly country.

\footnotetext{
of Finnish art]," Borba (April 17, 1964); Prvoslav Mitić, "Savremeno finsko slikarstvo - doživljaj finske umetnosti [Contemporary Finnish visual art-experience of Finnish art]," Borba (May 25, 1965); Darko Popović, "Obe strane granice: Tradicija i identitet - Arhitektura u Finskoj [Both sides of the border: Tradition and identity-Architecture in Finland]," Nin (March 16, 1980); "Izložba 'Finski oblik' u Muzeju za umetnost i obrt u Zagrebu [Exhibition "Finnish Form" in the Museum of Arts and Crafts in Zagreb]," Vjesnik (November 16, 1966); "Kći Baltičkog mora [Daughter of the Baltic Sea]," Politika (June 13, 1977); "Retrospektiva finskog graditeljstva od srednjeg veka do danas [Retrospective of Finnish architecture from the Middle Ages until today], Borba (February 25, 1980); "Finska primenjena umetnost [Finnish applied arts]," Politika (October 8, 1966).

24 The organization's activities were described on the occasion of its $25^{\text {th }}$ anniversary in Hannes Markkula, Armi Sarvaslahti, Helena Paalanen. Suomi-Jugoslavia Seura 25 Vuotta: Juhlajulkaisu [The Finnish-Yugoslav Society 25 Years: Celebration] (Helsinki: Suomi-Jugoslavia seura, 1983). The society was succeeded in 2000 by the Serbian-Finnish Society (Serbialais-Suomalainen Seura). ${ }^{25}$ Ruždjak had won international acclaim, having sung at Metropolitan Opera from 1962 to 1964 and with more than two thousand opera performances in his main opera houses of Zagreb and Hamburg from the 1950s to the mid-1970s.
} 


\begin{tabular}{|c|l|l|}
\hline Year & \multicolumn{1}{|c|}{ Name of event } & \multicolumn{1}{c|}{ Program } \\
\hline 1975 & $\begin{array}{l}\text { Yugoslav Culture } \\
\text { Days }\end{array}$ & $\begin{array}{l}\text { Exhibition on the Dubrovnik Summer Festival, and } \\
\text { guest performances by the Zagreb Quartet and Zagreb } \\
\text { opera soloists Vladimir Ruždjak and Nada Siriščević }\end{array}$ \\
\hline 1981 & $\begin{array}{l}\text { Yugoslav Week in } \\
\text { Finland }\end{array}$ & $\begin{array}{l}\text { Music and visual arts: Concerts of 2 Finnish choirs, } \\
\text { Serbian violinist Maja Jokanović; 3 exhibitions and a } \\
\text { screening of the war movie Occupation in 26 images } \\
(\text { Okupacija u 26 slika }) \text { by Lordan Zafranović }\end{array}$ \\
\hline 1985 & $\begin{array}{l}\text { 200 years Vuk } \\
\text { Stefanović Karadžićs } \\
\text { birth (Helsinki) }\end{array}$ & $\begin{array}{l}\text { Days of Yugoslavia } \\
\text { Exhibition on everyday village life; a movie on World } \\
\text { War memorials }\end{array}$ \\
\hline
\end{tabular}

Table 2. Mixed events as a result of the Finnish-Yugoslav friendship in the 1970s and the 1980s. ${ }^{26}$

Books and art works traveled easily to Yugoslav and Finnish audiences and institutions, but live contact of artists was the other side of cultural exchange of opinions and values between the "land of a thousand lakes" and the "country of brotherhood and unity." According to the Yugoslav press, the most common guest artists in Yugoslavia were painters, graphic designers and architects from Helsinki, Tampere, Jahta and Kuopio. Nevertheless, live music performances, as artistic expressions in real time and in front of the audience, had a special place in the cultural exchange between Finland and Yugoslavia.

Musicians from former Yugoslavia started visiting Finland at the beginning of the 1960s, but in the context of successful subsequent cooperation it is important to mention the mutual visits of representatives of cultural institution. To set the ground for actual musical exchange, opera and theatre institutions from the two countries first exchanged visits, such as those of Finnish conductor Arvi Kivimaa (1901-1984) and Milan Bogdanović, the head of the Belgrade National Theatre. As a result of their visits, numerous musical performers gave concerts in the other country. Their bilateral dialogue covered many different musicians, such as pianists, violinist, opera singers, chamber ensembles, etc.

As pioneers of this cultural exchange with Finland, Yugoslavia sent in 1960 two renowned musicians: opera singer Miroslav Čangalović (1921-1999), who was internationally renowned for his performance of Russian music, and Živojin Zdravković (1914-2001), the conductor of the Belgrade Philharmonic Orchestra

\footnotetext{
26 See Press clipping collection of Yugoslav newspapers and magazines kept at the Documentation Department of Radio Belgrade.
} 
and the founder of the Symphonic Orchestra of Cairo, who received a prestigious prize in Germany as one of the best performers of Tchaikovsky. In 1963, the most prominent Croatian chamber string orchestra, the Zagreb Soloists, with its conductor and founder of Italian origin Antonio Janigro (1918-1989) performed in Helsinki.

To mark the centenary of the birth of the most important Finnish composer, Jean Sibelius (1865-1957), a number of concerts were organized in Yugoslavia in 1965. Ten years later, among other compositions, music by Sibelius was performed by the Finlandia Quartet at the most important festival in former Yugoslavia-the Dubrovnik Summer Festival. ${ }^{27}$ In the 1980s, Serbian violinist Maja Jokanović (1953) performed Sibelius' Violin Concerto at the Sibelius Music Academy in Helsinki, and performed as a guest in Finland several more times.

There were also significant visits to Yugoslavia by Finnish classical musicians. Maija-Liisa Pohjola (1936), who is considered one of the best Scandinavian pianists of all time and is still active, performed at the Kolarac Hall in Belgrade in 1966.28 Pohjola's recital program included contemporary Finnish composers like Erik Bergman (1911-2006), Kalevi Ensio Aho (1949) and Mikko Heiniö (1948). As part of the cultural exchange, cellist Arto Noras (1942), one of the most distinguished classical musicians from Finland, performed in Belgrade several times. In 1979, he played at the Kolarac

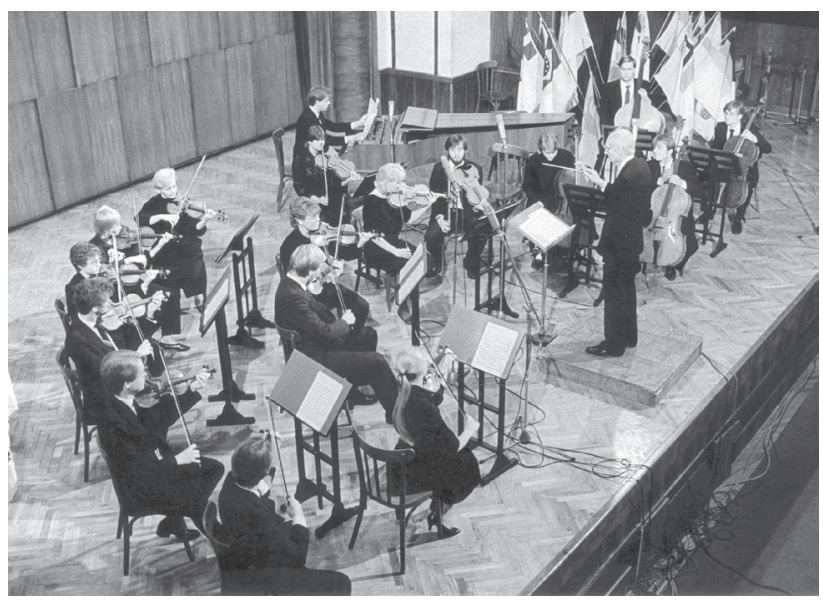

Figure 3. Finnish chamber orchestra on International Jeunesses Musicales Competition in Belgrade, Kolarac Hall. IJMC Archive-Jeunesses Musicales Belgrade, https://muzicka-omladina.org/takmicenje/rhiv.html?start=5.

\footnotetext{
${ }^{27}$ Established in 1969, the Finlandia Quartet was dedicated to performing and recording the music of Finnish composers: Jean Sibelius, Joonas Kokkonen (1921-1996), Aulis Sallinen (1935) and Einojuhani Rautavaara (1928-2016). Members of the Finlandia Quartet performing in Dubrovnik were Olavi Pälli (first violin), Jussi Pesonen (second violin), Esa Kamu (viola) and Heikki Rautasalo (cello). See Ruth-Esther Hillila, Barbara Blanchard Hong, Historical Dictionary of the Music and Musicians of Finland (Westport, Connecticut/London: Greenwood Press, 1997), 73.

${ }^{28}$ According to program records in the archives of the Jugokoncert concert agency.
} 
Hall with our prominent pianist and pedagogue Andreja Preger (1912-2015). A year earlier, Noras performed at the Dubrovnik Summer Festival. Other musicians from Finland who visited Belgrade included conductor Paavo Rautio, Matti Tuloisela and Arvo Airaksinen. Finally, the Sibelius Academy Chamber Orchestra, under the baton of conductor and violinist Tuomas Jaakko Haapanen (1924), performed and won second prize at the International Jeunesses Musicales Competition in Belgrade in 1986. ${ }^{29}$

\section{Conclusion}

Before making our final remarks on the cultural diplomacy between Finland and Yugoslavia, we have to briefly return to some of the issues outlined in the introduction. As already mentioned, the new circumstances following the dissolution of the SFRY implied a different approach to foreign policy in successor states. The image of war-torn successor states changed in the international perspective and relations with other countries. To recall this moment of change, we can use example the Finnish folk rock band Slobo horo from Tampere, which uses not only Serbian folklore from the western part of the country, but also taught that include in a band name reference to then Serbian President Slobodan Milošević, so their first album "Mastika" was banned on radio and TV stations in 1992. ${ }^{30}$ This illustrates quite clearly how the Finnish public quickly reacted to the influences of nationalistic figures and their values. We can confirm that in the 1990s the interest in relations between Finland and former Yugoslav republics decreased.

Keeping in mind the entire process of cultural cooperation between Finland and Yugoslavia, it is very important to emphasize the differences in these two countries' approach to more controversial artistic practices, namely to a wide range of avant-garde practices in contemporary art in the late 1980s and in popular culture from the start of the 1990s. In addition to the abovementioned practices in contemporary visual arts, it is more scientific rewarding to conclude this retrospective of events that marked the three decades of Yugoslav-Finnish friendship with theatrical practices.

It was obvious that Finland was fascinated by the enormous amount of energy that the SFRY invested in the construction of a prestigious image of the state at international events, such as the Dubrovnik Summer Festival or the Belgrade International Theatre Festival (BITEF). ${ }^{31}$ Considering many examples from the men-

\footnotetext{
${ }^{29}$ See IJMC Archive-Jeunesses Musicales Belgrade, https://muzicka-omladina.org/takmicenje/ rhiv.html?start $=5$.

${ }^{30}$ For more on this band, see Dragan Bisenić "Slobo horo," Nin (January 27, 2000): 51-52. This band was formed in 1986.

${ }^{31}$ In this sense, we can highlight the Finnish theatre play Kalevala directed by Jorma Uotinen and performed by the theatre troupe of the Helsingin Kaupunginteatteri at the $21^{\text {st }}$ Belgrade International Theatre Festival in 1987. For more on this event, see "Bitef 'Kalevala'," Oslobođenje (September 16, 1987) in the Press clipping collection of Radio Belgrade in the Yugoslavia and Finland Fond.
} 
tioned festivals we conclude that "Yugoslavia was the only country where something impossible was possible - to see theatres from the Soviet Union and Czechoslovakia appear on the same festival stage immediately after the aggression of the Warsaw Pact forces on the democratically oriented government in Czechoslovakia." ${ }^{2}$ In this sense, Finland's approach to Yugoslavia as a common ground for new artistic practices and an inspiration for establishing more freedom for artists in the public space. The SFRY, on the other hand, saw Finland as an inspiration in architecture, especially the works of Alvar Arto, but also in other fields of visual arts.

Moreover, we can conclude that the presentation of Yugoslav visual artists, literature and folklore in Finland was meant for the ordinary people, as well as academicians, art experts, diplomats, etc. Reviewing the encounter of Finnish artists/ artistic practices with the Yugoslav public, we can confirm a common perception of Yugoslavia as an oasis for avant-gardes practices, that is for a different kind of freedom as a result of its openness to even different ideological positions with respect to art. In music, as presented in this paper, the Finnish-Yugoslav relations reflected a complete reproduction of the "painful" issues in the Cold War division that influenced the culture of these two countries. In addition, both countries were rich in musicians that represented the Russian operatic repertoire, or in the case of Yugoslav musicians, were fighting for a position of renowned performers of the Classical and Romantic music repertoire tailored to the taste of the Western European public and institutions. In this respect, we cannot take for granted the important fact that "classical music, theatre, ballet, fine art [...] held a central place in the Soviet Union's enlightenment project at home, as well as in its self-projection abroad as the savior of European civilization." 33

The rich discourse on the importance of music, film and literature as part of the cultural cooperation or "cultural war" between the great powers, the US and the USSR, was in our case an inspiration for research on small-scale power management-cultural cooperation policies. The discourse on concrete diplomatic projects with jazz musicians as ambassadors of the United States and Hollywood as the strongest influence in the previous history, served as an inspiration for in-depth research on the Finnish and Yugoslav cultural crossroads, which we observe as relatively autonomous from the clashes of great powers, and guided by their local interest and artistic resources.

\footnotetext{
${ }^{32}$ Cf. Jovan Ćirilov, "Beograd i Bitef [Belgrade and BITEF]," Limes plus (Special edition on the Cold War) 1 (2013): 165.

${ }^{33}$ Susan E. Reid, "Foreword," in Music, Art and Diplomacy: East-West Cultural Interactions and the Cold War, edited by Simo Mikkonen, Pekka Suutari (London: Routledge, 2017), xiii.
} 


\section{Primary sources:}

Archival sources

Archives of the Jugokoncert Concert Agency (Belgrade)

Documentation Department of the Radio Belgrade (Belgrade): Yugoslavia and Finland Fond
Press and periodicals

Jugoslovenski pregled, Belgrade, 1957-2002

\section{Internet sources:}

IJMC Archive-Jeunesses Musicales Belgrade, https://muzicka-omladina.org/takmicenje/ rhiv.html?start=5.

\section{References:}

Aunesluoma, Joana, Kettunen Pauli (Eds.). The Cold War and the Politics of History. Helsinki: Edita Publishing Ltd, University of Helsinki, Department of Social Science History, 2008.

Bilandžić, Vladimir, Dahlmann, Dittmar, Kosanović, Milan (Eds.). From Helsinki to Belgrade: The First CSCE Follow-up Meeting and the Crisis of Détente. Internationale Beziehungen: Theorie und Geschichte, 10. Gottingen: Bonn University Press, 2012.

Bisenić, Dragan. "Slobo horo." Nin (January 27, 2000): 51-52.

Ćirilov, Jovan. "Beograd i Bitef." Limes plus (Special edition on the Cold War) 1 (2013): 165-168.

Cummings, Milton C. Cultural Diplomacy and the United States Government: A Survey. ICD Institute for Cultural Diplomacy, Centre for Arts and Culture, 2003.

Đurišić, Jelena (Ed.). Beograd-Helsinki: 90 godina diplomatskih odnosa. katalog izložbe / Belgrade-Helsinki: 90 Years of Diplomatic Relations, exhibition catalogue. Belgrade: Archives of Yugoslavia, 2019.
Eschen, Penny von. Satchmo Blows Up the World: Jazz Ambassadors Play the Cold War. London: Harvard University Press, 2004.

Hillila, Ruth-Esther, Blanchard Hong, Barbara. Historical Dictionary of the Music and Musicians of Finland. Westport, Connecticut-London: Greenwood Press, 1997.

Jakovina, Tvrtko. Treća strana Hladnog rata. Zagreb: Fraktura, 2011.

Jovanović, Vladimir. Beogradska opera u Evropi. Gostovanja od 1954 do 1969. Novi Sad: Akademija umetnosti, Prometej, 1996.

Kettunen, Pauli, Aunesluoma, Joana. "History in the Cold War and the Cold War in the Present." In The Cold War and the Politics of History, edited by Joana Aunesluoma, Pauli Kettunen, 9-18. Helsinki: Edita Publishing Ltd: University of Helsinki, Department of Social Science History, 2008.

Krstić, Marija. "SFR Yugoslavia during the Cold War and current Serbian foreign policy." Anthropology: journal of the Center for Ethnological and Anthropological Research 11/1 (2011): 21-44. 
Kullaa, Rinna E. "From the Tito-Stalin Split to Yugoslavia's Finnish Connection: Neutralism before Non-Alignment, 19481958." PhD diss., University of Maryland, 2008.

Kullaa, Rinna E. Non-Alignment and Its Origins in Cold War Europe: Yugoslavia, Finland and the Soviet Challenge. London: I. B. Tauris, 2012.

Kullaa, Rinna E. "The Birth and Development of the CSCE: Finnish and Yugoslav Models for Neutrality in the Early Cold War." In From Helsinki to Belgrade: The First CSCE Follow-up Meeting and the Crisis of Détente, edited by Vladimir Bilandžić, Dittmar Dahlmann, Milan Kosanović, 39-58. Internationale Beziehungen: Theorie und Geschichte, 10. Gottingen: Bonn University Press, 2012.

Laitinen, Pauli. "Međunarodni ekonomski odnosi Finske u razdoblju od 1956. do 1975. godine." In Urho Kekkonen: Borac za mir, edited by R. Vukadinović, 143-164. Zagreb: Globus, 1977.

Lampe, John R. Yugoslavia as History. Twice There Was a Country. Cambridge: Cambridge University Press, 2000.
Markkula, Hannes, Sarvaslahti, Armi, Paalanen, Helena. Suomi-Jugoslavia Seura 25 Vuotta: Juhlajulkaisu. Helsinki: SuomiJugoslavia seura, 1983.

Mates, Leo. Međunarodni odnosi Socijalističke Jugoslavije. Belgrade: Nolit, 1976.

“Odnosi Jugoslavije i Finske." Jugoslovenski pregled 3 (1975): 127-130.

Petranović, Branko. Istorija Jugoslavije 1918-1988: Socijalistička Jugoslavija 1945-1988. Vol. III. Belgrade: Nolit, 1988.

Reid, Susan E. "Foreword." In Music, Art and Diplomacy: East-West Cultural Interactions and the Cold War, edited by Simo Mikkonen, Pekka Suutari, xi-xiviii. London: Routledge, 2017.

Smith, Tony. "New Bottles for New Wine: A Pericentric Framework for the Study of the Cold War." Diplomatic History 24/4 (2000): 567-591.

Vasiljević, Maja. "View to Cold War Through Pericentric Lenses: Tito’s Yugoslavia and Kekkonen's Finland." Limes plus (Special edition on the Cold War) 1 (2013): 9-28.

Vukadinović, Radovan (Ed.). Urho Kekkonen: Borac za mir. Zagreb: Globus, 1977. 


\section{Notes on Contributors}

Ivana Vesić holds a $\mathrm{PhD}$ in Sociology and an MA in Sociology and Musicology. She is a Research Associate at the Institute of Musicology SASA (Belgrade, Serbia). Her research is focused on the sociohistorical dimensions of art and popular music practices in Serbia and Yugoslavia from the 1850s to the 2000s, with an emphasis on the issues of musical taste and consumption, music and politics, music and cultural policy, etc. She has published more than thirty articles and book chapters in scientific journals and collective editions. Ivana is the author of the book Konstruisanje srpske muzičke tradicije u periodu izmedu dva svetska rata [The Constructing of the Serbian Music Tradition in the Period between the Two World Wars] (Institute of Musicology SASA, 2018), and a co-author of the book on the functioning of music associations in the Kingdom of SCS/Yugoslavia (Institute of Musicology SASA, 2017). She is also a co-editor of a collective volume on Kosta P. Manojlović (Institute of Musicology SASA, 2017).

Vesna Peno holds a PhD in History, MA in Musicology, and BA in Serbian Literature, Language and Comparative Literature. She is a Principal Research Fellow at the Institute of Musicology SASA (Belgrade, Serbia). The main field of her research is Byzantine, post-Byzantine, and Serbian Church Music, as well as the history of Serbian literature on the music of the 19th and 20th century. She has published numerous studies and articles in Serbia and abroad. Vesna is the author of three books as well as a co-author of a book dedicated to Yugoslav associations of musicians. She co-edited the volume Aspects of Christian Culture in Byzantium and Eastern Christianity: Word, Sound and Image in the Context of Liturgical and Christian Symbolism (2017), and a volume on Kosta P. Manojlović (Institute of Musicology SASA, 2017).

Boštjan Udovič holds a $\mathrm{PhD}$ in International Economics, and a BA in International Relations. He is an Associate Professor in Diplomatic Studies at the Faculty of Social Sciences, University of Ljubljana (Slovenia). He teaches courses related to international political economy and diplomacy. His research areas are International Political Economy and Diplomatic Studies (commercial and cultural diplomacy). He was in 2013 awarded with a prize for Young University Teachers at the University of Ljubljana for his excellence in his pedagogical work. Boštjan has published several books, among them the History of (commercial) Diplomacy, and Cultural Diplomacy of Slavic States in the European Union. He also (co)authored different articles related to topics of diplomatic studies and International Political Economy. 
Ivana Tomić Ferić is a $\mathrm{PhD}$ in Musicology. She is a Full Professor at the Arts Academy University of Split (Croatia). Ivana is interested in the exploration of Croatian music from the 18th to the 20th century. She authored two books and several dozen scholarly articles. She is the main researcher of the project Musical Sources of Dalmatia in the Context of the Central-European and Mediterranean Musical Culture from the $18^{\text {th }}$ to $20^{\text {th }}$ Century. She is a member of the Editorial Board of the journals Bašćinski glasi and Arti musices. In 2013, her book Julije Bajamonti: Music Dictionary. Transcription, Translation, Commentaries (2013) received three awards: the "Dragan Plamenac Award" of the Croatian Musicological Society, the "Josip Andreis Award" by the Croatian Composer's Society and the annual award of the Croatian Academy of Sciences and Arts for the highest scholarly achievements in the Republic of Croatia for art music. University of Split assigned to her "Award for Science" (2016) for the past scientific contribution in the field of Humanities and Social Sciences.

Goran Vasin is a PhD in History. He is an Associate Professor at the Department of History of the Faculty of Philosophy, University of Novi Sad (Serbia). His areas of research include the history of Serbs in the Habsburg Monarchy, history of Serbian Orthodox Church, and the history of Serbia and Montenegro with the focus on the period from the $18^{\text {th }}$ to $20^{\text {th }}$ century. He published more than sixty scientific papers and chapters and is an author and co-author of seven books.

Ratomir Milikić holds a $\mathrm{PhD}$ in History. He is a Senior Research Associate at the Institute for Contemporary History (Belgrade, Serbia). Previously, he held various diplomatic positions. His research interests lie primarily in the area of Serbian and Yugoslav diplomatic history during the twentieth century, as well as post-war history of diplomacy of Yugoslavia with particular reference to relations with France, Russia, USA, the United Kingdom, Greece and Turkey and contacts with international organizations (primarily the Council of Europe and the UN), multilateral, cultural and parliamentary diplomacy. His publications include seven books and few dozen articles in international and national scientific journals. Since 2018, he has been a member of the Council of the Historical Museum of Serbia.

Ranka Gašić is a PhD in History. She is a Principal Research Fellow at the Institute of Contemporary History (Belgrade, Serbia). Her areas of expertise are social and cultural history of the interwar period, urban studies, and economic history of the 20th century. She published three books and numerous papers. She is a member of the Association for Social History in Belgrade, Center for History, Democracy and Reconciliation in Novi Sad, and Center for Economic History in Belgrade. 
Srdan Atanasovski holds a PhD in Musicology. He is a Research Associate at the Institute of Musicology SASA (Belgrade, Serbia). His research focuses on the topics of nationalism, culture, and music in the Yugoslav space. He has been engaged in two international projects, Figuring Out the Enemy: Re-Imagining Serbian-Albanian Relations (led by the Institute for Philosophy and Social Theory in Belgrade) and City Sonic Ecology: Urban Soundscapes of Bern, Ljubljana, and Belgrade, funded by the Swiss National Science Foundation (SNSF). His articles have appeared in journals Southeastern Europe, Studies in Eastern European Cinema, Südosteuropa, Musicological Annual, etc., as well as in different edited volumes published by Brill, Ashgate, Transcript and other international academic publishers. His first book, Mapiranje Stare Srbije. Stopama putopisaca, tragom narodne pesme [The Mapping of Old Serbia: In the Footsteps of Travel Writers, Tracing the Folk Song] was published in 2017 by Biblioteka XX vek.

Stefanka Georgieva holds a PhD in Musicology. She is a Full Professor at the Faculty of Education of the Trakia University (Stara Zagora, Bulgaria). Her main areas of scientific interest are: European musical culture of the first half of the 20th century (musical neoclassicism, Igor Stravinsky), Bulgarian musical culture (music criticism, historiography), musical and cultural connections of Bulgarian and South-Eastern countries. She has published three books on neoclassicism in music (Sofia, 1989), the work of Andrei Bersenev (Stara Zagora, 1997), and Igor Stravinsky (Stara Zagora, 2013). She has also authored numerous textbooks.

Florinela Popa is a PhD in Musicology. She is an Associate Professor at the National University of Music (Bucharest, Romania). Her main field of research is the relationship between music and ideology in the 20th century. Her publications include the book Mihail Jora. A European Modern (Bucharest, 2009), Sergei Prokofiev (Bucharest, 2012), and numerous articles in musicological books and journals. She is co-editor of ten volumes in the series Documents in the Archives of the George Enescu National Museum: Articles on George Enescu in Periodicals (Bucharest, 2009-2017). In 2012, she was awarded the Union of Romanian Composers and Musicologists Prize for historiography.

Lenka Krrupková holds a $\mathrm{PhD}$ in Musicology. She completed her postgraduate studies with her dissertation on The Chamber Works of Vitězslav Novák. Since 1995, she has been working at the Department of Musicology of Palacký University, Olomouc, where she qualified as an Associate Professor. Lenka has been a head of this department since 2012. Her main areas of research interest are Czech music 
of the $19^{\text {th }}$ and $20^{\text {th }}$ centuries, Czech and European chamber music, music theatre, sociology of music, and music editing. She has published a number of articles and six books. Together with Jiří Kopecký, Lenka Křupková is one of the main authors of Czech Music around 1900 (Pendragon Press, 2017).

Aleksandra Kolaković holds a $\mathrm{PhD}$ in History. She is a Research Associate at the Institute for Political Studies (Belgrade, Serbia). Together with Sacha Markovic, she manages the project France and the Western Balkans: the legacy of the past and the EU integration process (Institute for Political Studies and EUR'ORBEM, Sorbonne Universités, Université Paris-Sorbonne). She is a member of the expert council of the Institute for the Study of Cultural Development of Serbia (2020-) and the Board of the Belgrade City Museum (2018-). Aleksandra's main areas of academic interest are the fields of intellectual history, history of ideas, as well as the cultural history of the Balkans, cultural diplomacy, culture of remembrance, protection of cultural heritage and methodology of history teaching. She's the author of the book U službi otadžbine: saradnja francuskih i srpskih intelektualaca 1894-1914 [For the Homeland: Cooperation of French and Serbian Intellectuals 1894-1914], two history textbooks, one lexicon (Lexicon of Multiculturalism) and more than 30 scholarly papers.

Biljana Milanović obtained a Magister Degree in Musicology at the Faculty of Music, University of Arts, in Belgrade, and a PhD at the Department of History of the Faculty of Philosophy, University of Belgrade. She works as a Research Associate at the Institute of Musicology SASA (Belgrade, Serbia). Her scholarly interests include $19^{\text {th }}$ and the first half of $20^{\text {th }}$ century music, which she tends to integrate into critical studies of culture and history. She has prepared and edited several scholarly publications, authored one book, and written more than 80 studies in Serbian, English, French, German, and Greek, which were published in scholarly journals and edited books. She was vice president of the Musicological Society of Serbia (2012-2018). She is one of the founders and members of the editorial board of the journal Muzikologija (since 2001) and a member of the board of the Department of Stage Arts and Music of Matica srpska in Novi Sad.

Ivan Hofman is a historian. He is an Archives Advisor at the Archives of Yugoslavia (Belgrade, Serbia), and a lecturer at the Petnica Scientific Center. There are several fields of his scientific interest: archival theory and practice, culture and art as tools of ideological and political action (especially in the case of socialist Yugoslavia), and the relationship between the Communist Party of Yugoslavia and Yugoslav youth. 
He published one book and several papers in leading Serbian historical journals. $\mathrm{He}$ is an author of one exhibition of archival records and co-author of a collection of documents concerning the cultural policy of socialist Yugoslavia.

Julijana Papazova received a $\mathrm{PhD}$ in Musicology at the Institute of Art Studies of the Bulgarian Academy of Sciences in Sofia. She teaches History of Popular Music at the Ss Cyril and Methodius University (Skopje, Northern Macedonia). Her main areas of research are: popular music studies, alternative rock in Central and Southeast Europe. Her papers are published by Hollitzer (Vienna), Hudební věda (Prague), Peter Lang (Frankfurt), Rowman \& Littlefield (Maryland) an appeared in the IASPM@Journal, the Journal of Creative Communications (SAGE), Bulgarian Musicology (Sofia), Arti musices (Zagreb), etc. During the summer semester of 2019, Julijana was SAIA postdoctoral researcher at Comenius University in Bratislava. She is the author of the book Alternative rock in Yugoslavia in the period 1980-1991 (LAP, 2017).

Maja Vasiljević is a PhD in Sociology, and MA in Sociology and Musicology. She works as a Research Assistant at the Faculty of Philosophy, University of Belgrade (Serbia). She published a monograph Filmska muzika u SFRJ: izmedu politike $i$ poetike [Film Music in SFRY: Between Poetics and Politics] (Hera edu, 2016) and many papers on different topics: film music, military music, music and Jewish community from Ottoman Empire to Holocaust, racism, gender, and minority politics in occupied Belgrade in WWII, social movements and music and music in the Great War. 

THE TUNES OF DIPLOMATIC NOTES

Music and Diplomacy in Southeast Europe $\left(18^{\text {th }}-20^{\text {th }}\right.$ century)

Ivana Vesić, Vesna Peno, Boštjan Udovič (Eds.)

\section{Publishers}

Institute of Musicology SASA

Knez Mihailova 36

11000 Belgrade, Republic of Serbia

Faculty of Social Sciences, University of Ljubljana

Kardeljeva ploščad 5

1000 Ljubljana, Republic of Slovenia

\section{For publishers}

Katarina Tomašević,

Director of the Institute of Musicology SASA

Monika Kalin Golob,

Dean of the Faculty of Social Sciences, University of Ljubljana

\section{Reviewers}

Milan Ristović, PhD, Full Professor,

Faculty of Philosophy, University of Belgrade

Lana Paćuka, PhD, Associate Professor, Academy of Music, University of Sarajevo

Aleksandar Vasić, PhD, Research Associate, Institute of Musicology SASA, Belgrade

\section{Language editors}

Aleš Lampe

Biljana Jocić

\section{Design}

Milan Suput

Prepress

Siniša Stojanović

Printed by

Donat Graf doo, Belgrade

Circulation

300

ISBN 978-86-80639-54-3

https://doi.org/10.18485/music_diplomacy.2020 
CIP - Каталогизација у публикацији Народна библиотека Србије, Београд

$327: 316.7(4-12) " 17 / 19 "(082)$

$78: 316.4(082)$

$316.7(4-12)(082)$

The Tunes of Diplomatic Notes: Music and Diplomacy in Southeast Europe : (18th-20th century) / edited by Ivana Vesić, Vesna Peno, Boštjan Udovič. - Belgrade : Institute of Musicology SASA ; Ljubljana : University of Ljubljana, Faculty of Social Sciences, 2020 (Beograd : Donad graf). - 261 str. : ilustr. $; 24 \mathrm{~cm}$

"This edited collection is a result of the scientific project Identities of Serbian Music Within the Local and Global Framework: Traditions, Changes, Challenges (No. 177004, 2011-2019)..." --> prelim. str. - Tiraž 300. - Notes on Contributors: str. 257-261. - Napomene i bibliografske reference uz radove. - Bibliografija uz svaki rad.

ISBN 978-86-80639-54-3 (IMSASA)

1. Vesić, Ivana, 1981- [urednik] 2. Peno, Vesna, 1968- [urednik]

3. Udovič, Boštjan, 1980- [urednik]

a) Музика - Социолошки аспект - Зборници b) Југоисточна Европа

- Културна дипломатија - 18в-20в - Зборници v) Југоисточна Европа

- Културна политика - Зборници

COBISS.SR-ID 28299017 

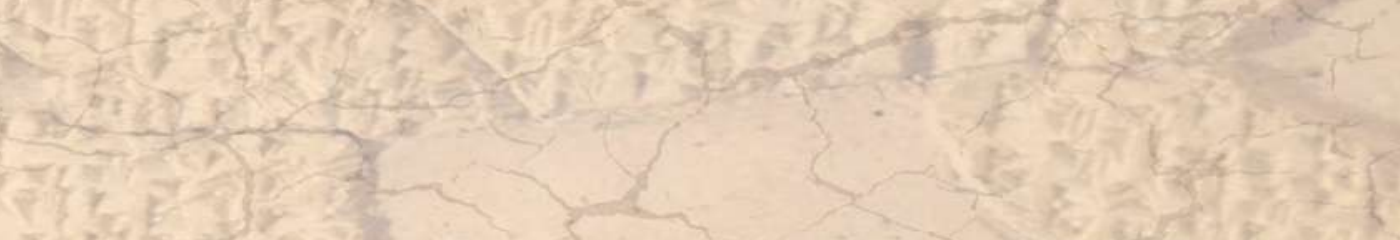

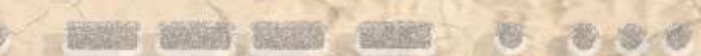

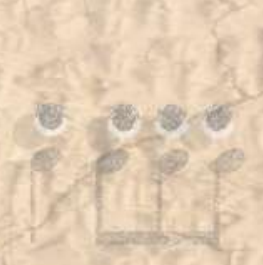

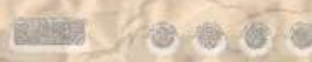

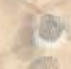
